\title{
Investigating Continuously Updated History Matching Using Smart Proxy (Surrogate Reservoir Model)
}

Qin $\mathrm{He}$

Follow this and additional works at: https://researchrepository.wvu.edu/etd

\section{Recommended Citation}

$\mathrm{He}$, Qin, "Investigating Continuously Updated History Matching Using Smart Proxy (Surrogate Reservoir Model)" (2016). Graduate Theses, Dissertations, and Problem Reports. 5786.

https://researchrepository.wvu.edu/etd/5786

This Dissertation is protected by copyright and/or related rights. It has been brought to you by the The Research Repository @ WVU with permission from the rights-holder(s). You are free to use this Dissertation in any way that is permitted by the copyright and related rights legislation that applies to your use. For other uses you must obtain permission from the rights-holder(s) directly, unless additional rights are indicated by a Creative Commons license in the record and/ or on the work itself. This Dissertation has been accepted for inclusion in WVU Graduate Theses, Dissertations, and Problem Reports collection by an authorized administrator of The Research Repository @ WVU.

For more information, please contact researchrepository@mail.wvu.edu. 


\title{
Feasibility and Supply Analysis of U.S. Geothermal District Heating and Cooling System
}

\author{
Xiaoning He \\ Dissertation submitted \\ to the Benjamin M. Statler College of Engineering and Mineral Resources \\ at West Virginia University \\ in partial fulfillment of the requirements for the degree of \\ Doctor of Philosophy in \\ Chemical Engineering
}

\author{
Brian Anderson, Ph.D., Chair \\ Timothy Carr, Ph.D. \\ Randall Jackson, Ph.D. \\ Richard Turton, Ph.D. \\ John Zondlo, Ph.D. \\ Department of Chemical Engineering
}

Morgantown, West Virginia

2015

Keywords: Geothermal energy, Direct use, Levelized cost of heat, Supply analysis

Copyright 2015 Xiaoning He 


\section{ABSTRACT \\ Feasibility and Supply Analysis of U.S. Geothermal District Heating and Cooling System}

\section{Xiaoning He}

Geothermal energy is a globally distributed sustainable energy with the advantages of a stable base load energy production with a high capacity factor and zero $\mathrm{SO}_{\mathrm{x}}, \mathrm{CO}$, and particulates emissions. It can provide a potential solution to the depletion of fossil fuels and air pollution problems. The geothermal district heating and cooling system is one of the most common applications of geothermal energy, and consists of geothermal wells to provide hot water from a fractured geothermal reservoir, a surface energy distribution system for hot water transmission, and heating/cooling facilities to provide water and space heating as well as air conditioning for residential and commercial buildings.

To gain wider recognition for the geothermal district heating and cooling (GDHC) system, the potential to develop such a system was evaluated in the western United States, and in the state of West Virginia. The geothermal resources were categorized into identified hydrothermal resources, undiscovered hydrothermal resources, near hydrothermal enhanced geothermal system (EGS), and deep EGS. Reservoir characteristics of the first three categories were estimated individually, and their thermal potential calculated. A cost model for such a system was developed for technical performance and economic analysis at each geothermally active location. A supply curve for the system was then developed, establishing the quantity and the cost of potential geothermal energy which can be used for the GDHC system.

A West Virginia University (WVU) case study was performed to compare the competiveness of a geothermal energy system to the current steam based system. An Aspen Plus model was created to simulate the year-round campus heating and cooling scenario. Five cases of varying water flow rates and temperatures were simulated to find the lowest levelized cost of heat ( $\mathrm{LCOH})$ for the WVU case study. The model was then used to derive a levelized cost of heat as a function of the population density at a constant geothermal gradient. By use of such functions in West Virginia at a census tract level, the most promising census tracts in WV for the development of geothermal district heating and cooling systems were mapped.

This study is unique in that its purpose was to utilize supply analyses for the GDHC systems and determine an appropriate economic assessment of the viability and sustainability of the systems. It was found that the market energy demand, production temperature, and project lifetime have negative effects on the levelized cost, while the drilling cost, discount rate, and capital cost have positive effects on the levelized cost by sensitivity analysis. Moreover, increasing the energy demand is the most effective way to decrease the levelized cost. The derived levelized cost function shows that for EGS based systems, the population density has a strong negative effect on the $\mathrm{LCOH}$ at any geothermal gradient, while the gradient only has a negative effect on the $\mathrm{LCOH}$ at a low population density. 


\section{ACKNOWLEDGEMENTS}

It has been a productive, enjoyable, and a full of memory five years staying in West Virginia University in Morgantown, WV. I would like to acknowledge the following people and organizations that helped me in various ways throughout the duration of this project.

First I would like to sincerely thank my advisor, Dr. Brian Anderson, who guides me into the geothermal research and supports me since then. I am encouraged by his enthusiasm and dedication to the energy field, and have learned many things from him. I am grateful for those trips to Cornell University, Stanford University, and Portland that would not have been possible without his supports. Those are not only great opportunities to learn and to interact with new people, but also enjoyable times to new places.

I would like to thank U.S. Department of Energy (DOE) for providing funding to this project. I would also like to thank Dr. Chad Augustine from National Renewable Energy Laboratory for his help in my research.

I would like to thank my committee members: Dr. Timothy Carr, Dr. Randall Jackson, Dr. Richard Turton, and Dr. John Zondlo. I am grateful for their advice and help.

I would like to thank my colleges and my friends: Dr. Srinath Velaga, Dr. Nagasree Garapati, Dr. Manohar Gaddipati, Dr. Patrick McGuire, Madhur Bedre, Jason Peluchette, Taiwo Ajayi, Manish Nandanwar, and Prathyusha Sridhara. It is a wonderful experience working with them. I would like to thank Ms. Lisa Saurborn and the WVU facility office for their help in completing my research. I would also like to thank Dr. Jeff Tester and his geothermal research group members: Maciej Lukawski, Koenraad Beckers, whose collaboration has helped my research.

Finally, I would like to thank my parents and my wife for their supports, love, and encourages throughout my life.

Xiaoning $\mathrm{He}$

March $4^{\text {th }}, 2015$ 


\section{Table of Contents}

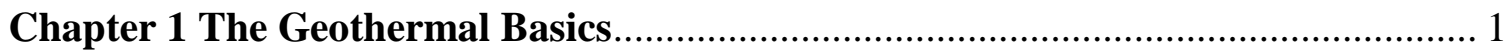

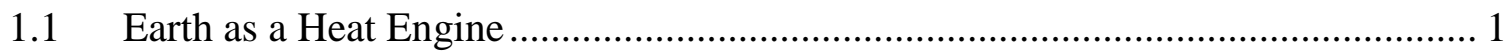

1.2 Using Geothermal Energy for Heat and Power …………………...................... 2

$1.3 \quad$ Background and Motivation ................................................................................ 6

$1.4 \quad$ World-wide Geothermal Development.............................................................. 7

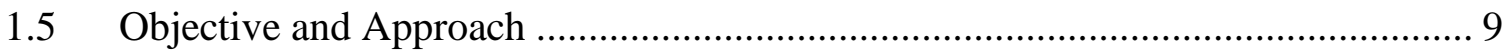

Chapter 2 Supply Analysis of Geothermal District Heating and Cooling Systems .. 11

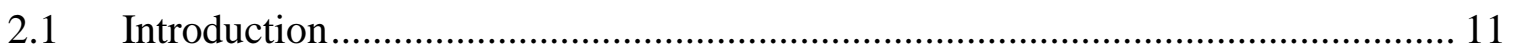

$2.2 \quad$ Levelized Cost of Heat.................................................................................... 12

2.3 Previous Studies on Geothermal Supply Analysis................................................ 14

2.4 Reservoir Characterization and Potential Estimation ............................................ 19

2.4.1 Geothermal Resources Categorization …………………………………...... 19

2.4.2 Identified Hydrothermal Resources................................................................ 20

2.4.3 Undiscovered Hydrothermal Resources .......................................................... 22

2.4.4 Near Hydrothermal EGS Resources ............................................................. 24

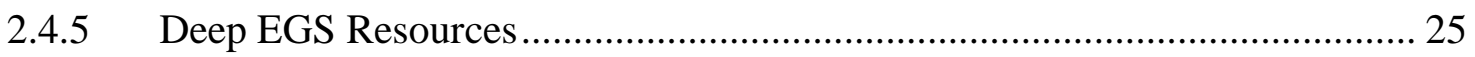

2.5 Energy Market Characterization ................................................................... 27

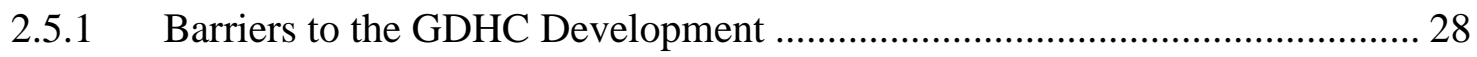

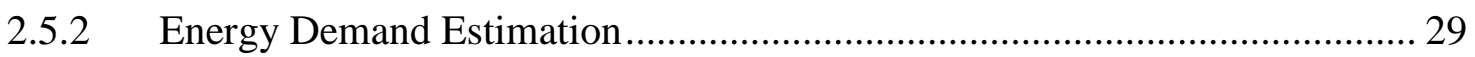

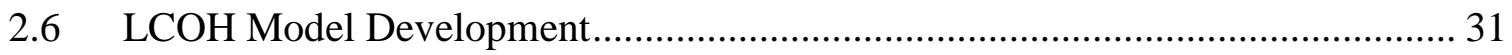

2.6.1 Surface Facility Design and Economics …….................................................... 32

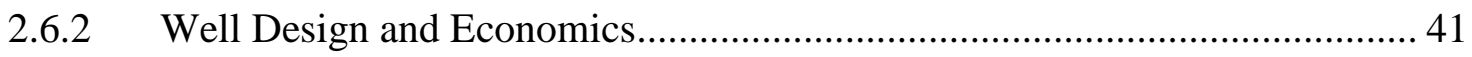

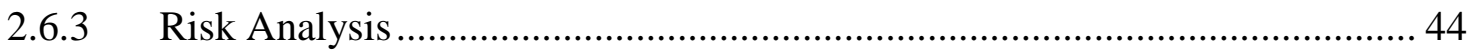

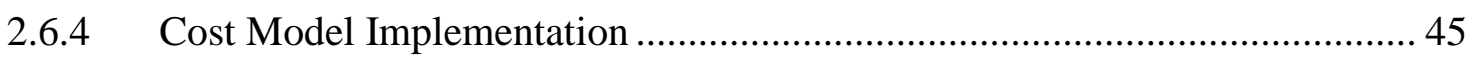




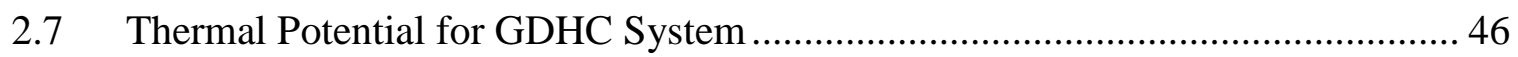

2.7.1 Identified Hydrothermal Resources............................................................... 46

2.7.2 Undiscovered Hydrothermal Resources …………........................................... 48

2.7.3 Near Hydrothermal EGS Resources ……………........................................ 49

2.8 LCOH Estimation and Supply Curve Development ........................................... 50

2.8.1 Identified Hydrothermal Resources............................................................ 50

2.8.2 Undiscovered Hydrothermal Resources ....................................................... 55

2.8.3 Near Hydrothermal EGS Resources ……………………………………..... 57

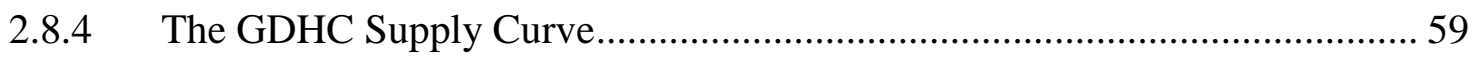

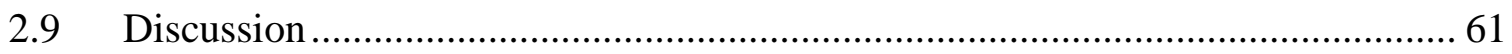

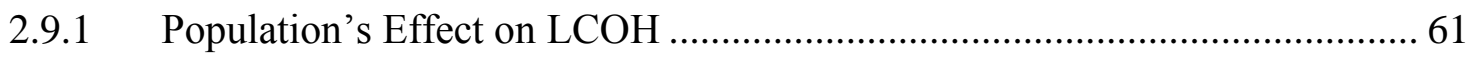

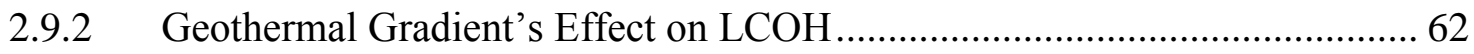

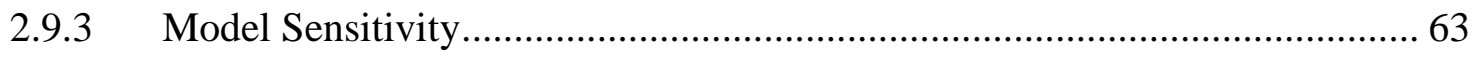

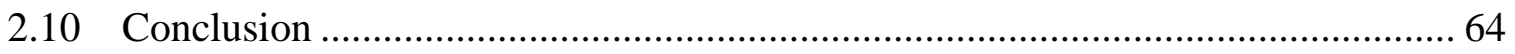

Chapter 3 Techno-Economic Assessment of GDHC systems: A Case Study on West

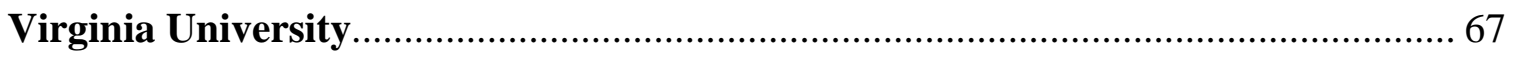

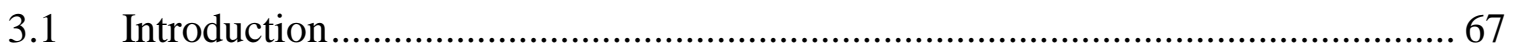

3.2 The Initial: West Virginia Geothermal Hot Spot .................................................... 68

3.3 Modeling the GDHC System on WVU Campus .................................................. 70

3.3.1 Existing Heating and Cooling Basics …………............................................. 71

3.3.2 Proposed Heating and Cooling System ……………………........................... 71

3.3.3 LCOH Calculation for WVU Case Study ..................................................... 74

3.4 Empirical LCOH Function Derivation.................................................................. 76

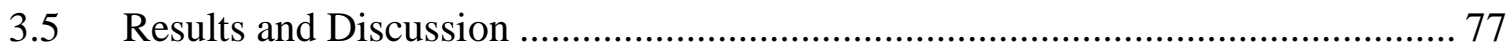

3.5.1 West Virginia Geothermal Maps ……………............................................. 77 
3.5.2 Campus GDHC Characterization ......................................................... 79

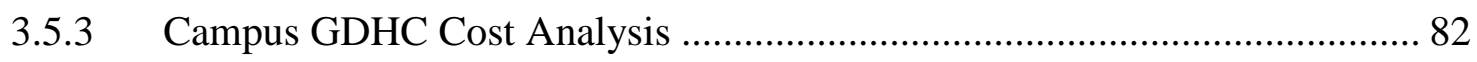

3.5.4 LCOH Functions and State Wide Estimation ............................................ 85

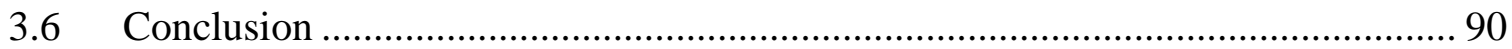

Chapter 4 Conclusions and Recommendations............................................... 92

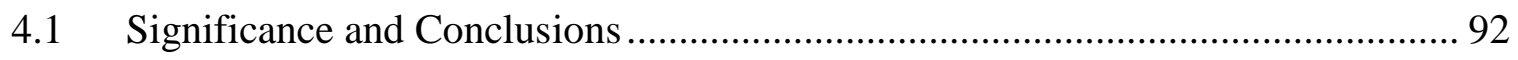

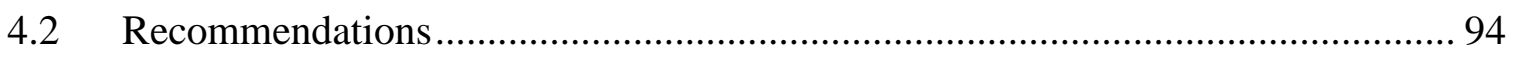

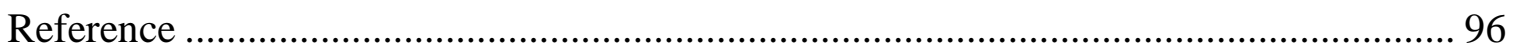

Appendix A: Geothermal Reservoir Characteristics and LCOH ................................ 105

Table A-1: Identified Hydrothermal Resources and Near Hydrothermal EGS ......... 105

Table A-2: Undiscovered Hydrothermal Resources ............................................ 132

Appendix B: WV Geothermal Temperature Maps ................................................. 135 


\section{List of Figures}

Figure 1.1: Heat flow map of the conterminous United States by SMU Geothermal Laboratory (Blackwell, et al., 2011).

Figure 1.2: The Lindal diagram shows different geothermal utilizations by temperature ranges (Gudmundsson, et al., 1985). 3

Figure 1.3: Schematic layout of a geothermal district heating and cooling system. DWP is deep well pump, SDT is storage and degassing tank, CP is circulation pump, PLB is peak load boiler, htw is hot water, and C is convention heating (Marcel, 2007). 4

Figure 1.4: Schematic of a two-well enhanced geothermal power generation system in hot rocks in a low permeability crystalline basement formation (Tester, et al., 2006)............ 5 Figure 1.5: World average energy consumption per person $\left(\times 10^{9} \mathrm{~J} / \mathrm{ppl} / \mathrm{year}\right)$ and population growth since 1970, data from (Glassley, 2010).

Figure 1.6: $\mathrm{CO}_{2}$ emission from fossil fuels, data from (EIA, 2011) and global mean surface temperature, data from (NASA, 2012) 7

Figure 1.7: Number of installed countries and installed capacity of geothermal direct use.

Figure 1.8: Installed capacity of the worldwide geothermal power generation since 1950 . It is expected to reach $70,000 \mathrm{MW}_{\mathrm{e}}$ in 2050.

Figure 2.1: Zhangbei area, China available wind power supply, plotted based on data from Kline, et al., 2008 . 13

Figure 2.2: Predicted levelized cost of electricity and cost breakdown for new generation resources in 2019, based on data from Annual Energy Outlook, 2014, U.S. EIA............ 14

Figure 2.3: Flow diagram to develop the supply curve of GDHC application. 19

Figure 2.4: The favorability factor map of undiscovered hydrothermal resources in the western U.S. A warmer color indicates a higher probability to find the hydrothermal resources (Williams, et al., 2009).

Figure 2.5: Map of underground temperature at $4.5 \mathrm{~km}$ of the continental U.S (Tester, et al., 2006).

Figure 2.6: Comparison of annual U.S. crude oil imports and renewable energy consumption from 2000 to 2014, based on data from U.S. EIA. 27

Figure 2.7: Flow diagram to estimate the energy demand of the target location..... 29 
Figure 2.8: The housing pattern with increase population and distribution network design.

Figure 2.9: Schematic of the building heating unit of a GDHC system.

Figure 2.10: Schematic of the absorption chiller, cooling provided at EVAP, geothermal hot water flows through HX-GEO. 40

Figure 2.11: The drilling cost function with drilling depth.

Figure 2.12: Histogram of the identified hydrothermal resources mass flow rates and the predicted probability density curve.

Figure 2.13: Pie chart of the remaining identified hydrothermal potential in each state, with a total of $47 \mathrm{GW}_{\mathrm{th}}$. 48

Figure 2.14: Pie chart of the undiscovered hydrothermal potential in each state, with a total of $159 \mathrm{GW}_{\text {th. }}$

Figure 2.15: Maps of the identified hydrothermal resources, coupled with a western U.S. geothermal temperature map at $6.5 \mathrm{~km}$. 51

Figure 2.16: Cost breakdown of the GDHC projects of identified hydrothermal resources.

Figure 2.17: Temperature profile of main streams of the GDHC system in the Weiser area in Idaho. 53

Figure 2. 18: Year-round flow rate profile of the geothermal production water of the GDHC system in the Weiser area in Idaho, corresponding to the daily system energy production.

Figure 2.19: Supply curve of the identified hydrothermal resources, truncated at $50 \mathrm{GW}_{\text {th }}$, in comparison with the current cost of heating by natural gas, which is $\$ 9.2 / \mathrm{MMBtu} . .55$ Figure 2.20: Cost breakdown of the GDHC projects of undiscovered hydrothermal resources.

Figure 2.21: Supply curve of the undiscovered hydrothermal resources, in comparison with the current cost of heating by natural gas, which is $\$ 9.2 / \mathrm{MMBtu}$ 57 Figure 2.22: Supply curve of the near hydrothermal EGS, truncated at \$100/MMBtu, in comparison with the current cost of heating by natural gas, which is $\$ 9.2 / \mathrm{MMBtu}$....... 58 Figure 2.23: Supply curve of the U.S. GDHC application with different categories of geothermal resources. 
Figure 2.24: Supply curve of the U.S. GDHC application.

Figure 2.25: Partial enlargement of the supply curve, in comparison with the current natural gas heating cost, which is $\$ 9.2 / \mathrm{MMBtu}$.

Figure 2.26: Population served by identified hydrothermal resource based GDHC systems versus their $\mathrm{LCOH}$. Blue dots are identified resources, and the trend line shows the predicted $\mathrm{LCOH}$ as a function of the population.

Figure 2.27: Geothermal gradients of the identified hydrothermal resources versus their calculated $\mathrm{LCOH}$ for the GDHC systems.

Figure 2.28: Sensitivity analysis of the cost model, showing energy demand has the most significant negative effect, while drilling cost has the most significant positive effect. .. 64 Figure 3.1: Geologic formations near Morgantown, WV at depth of 3 to $4 \mathrm{~km}$, the Tuscarora and Oswego Sandstone are of interest for GDHC development....

Figure 3.2: Layout of the Evansdale campus buildings (classroom, greenhouse, and library) and pipeline, based on which the Aspen Plus heating model was built. 73 Figure 3.3: Geothermal temperature map of West Virginia at $4.5 \mathrm{~km}$, black dots show the locations of oil and gas wells from which SMU updated their temperature profiles. ...... 78 Figure 3.4: Monthly heating and cooling demand of the Evansdale Campus, WVU....... 79 Figure 3. 5: Return temperature versus mass flow rate at selected supply temperatures to provide campus peak heating demand, dashed line indicates the minimum requirement for the return temperature. 80

Figure 3.6: Minimum mass flow rate versus supply temperature to supply campus heating demand. Dashed lines indicate one production and two production wells' maximum flow rate. Red dots indicate the selected pairs of temperature and flow rate for cost estimation.

Figure 3.7: $\mathrm{LCOH}$ for the WVU GDHC project with selected temperature and flow rate.

Figure 3. 8: Geothermal gradient map of WV, with a warmer color indicating a higher geothermal gradient. 86

Figure 3.9: Population density map of WV, with a warmer color indicating a higher population density. 86 
Figure 3.10: Census tracts map of WV, coupled with their estimated LCOH, with a warmer color representing a lower LCOH. Lowest LCOH is found at Morgantown, WV.

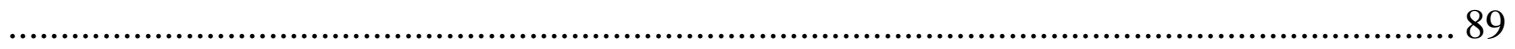

Figure 3.11: Plot showing the variation of $\mathrm{LCOH}$ function with population density and

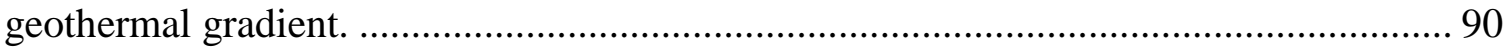




\section{List of Tables}

Table 2.1: Summary of geothermal power potential and levelized cost of electricity from

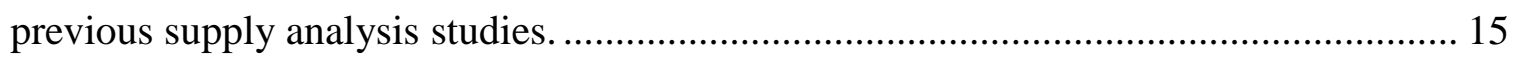

Table 2.2: Residential buildings heating/cooling consumptions (MMBtu/household) by

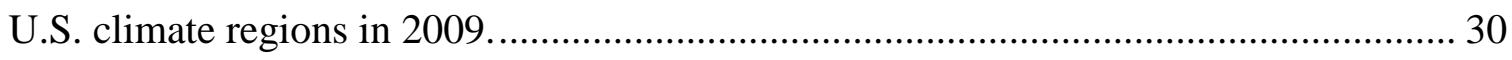

Table 2.3: Commercial buildings heating/cooling consumption (trillion Btu) of the mountain and the pacific region, in western U.S., 2003 ............................................. 30

Table 2.4: Cost constants for pipeline capital cost calculation...................................... 34

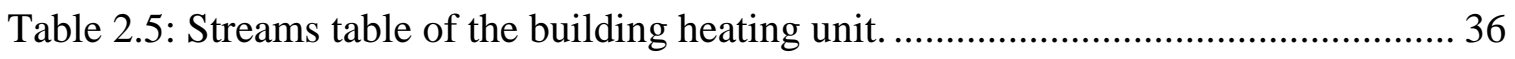

Table 2. 6: Streams table of the absorption chiller system. ......................................... 39

Table 2.7: Stimulation cost breakdown for a 2,500-meter well based on practices from the Marcellus shale industry.

Table 2.8: Probabilistic metrics for risk analysis in the cost model, data follows a triangle distribution, in the format of (minimum value, most likely value, maximum value)...... 45

Table 2.9: Favorability factor of different geothermal regions...................................... 48

Table 2.10: Cost summary for the simulated GDHC system at Weiser, ID.................... 52

Table 2.11: Cost summary for the simulated GDHC system in California with an

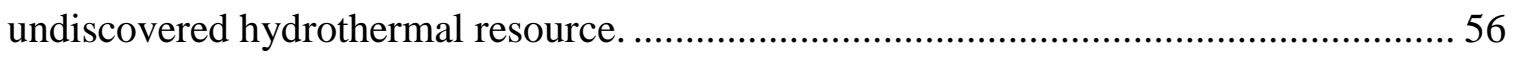

Table 2.12: Estimated thermal potential and the corresponding lowest $\mathrm{LCOH}$ from the

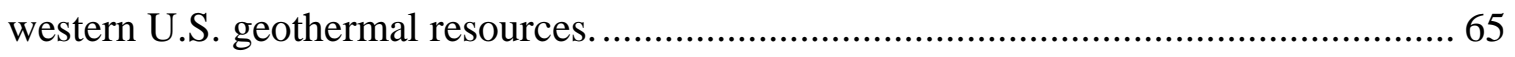

Table 3.1: Comparison of the geologic conditions between Gross Schoenebeck and Morgantown, WV, data from Hurter, et al. (Hurter, et al., 2002) and Castle and Byrnes

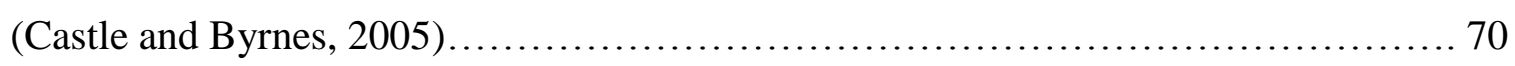

Table 3.2: Investigated cases of geothermal flow and temperature for WVU case study. 82 Table 3.3: Surface operation and maintenance cost estimation for case 2, in \$/per year, except for total direct cost, which is in $\$$. 83

Table 3.4: Cost summary of the proposed GDHC system on WVU campus, based on five selected temperature and flow rate cases.

Table 3.5: LCOH (\$/MMBtu) for the WVU campus GDHC system, in different geothermal water characteristics (case 1, 2, 3, 4, and 5) and different economic scenarios (case I, II, and III) 
Table 3.6: Least square fitting results of $\mathrm{LCOH}$ function constants $\mathrm{a}, \mathrm{b}$, and $\mathrm{n}$ for different

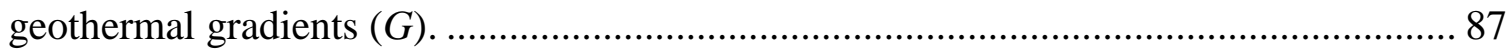
Table 3.7: Potential places for GDHC systems development in WV, whose LCOH is less than \$ 30/MMBtu. 88 


\section{Chapter 1}

\section{The Geothermal Basics}

"It is a well-known fact that the interior portions of the earth are very hot, the temperature rising, as observations show, with the approach to the center at the rate of approximately $1{ }^{\circ} \mathrm{C}$ for every hundred feet of depth. The difficulties of sinking shafts and placing boilers at depths of twelve thousand feet, corresponding to an increase in temperature of about $120^{\circ} \mathrm{C}$ are not insuperable, and we could certainly avail ourselves in this way of the internal heat of the globe. In fact, it would not be necessary to go to any depth at all in order to derive energy from the stored terrestrial heat. The superficial layers of the earth ... are at a temperature sufficiently high to evaporate some extremely volatile substances, which we might use in our boilers instead of water."

--- Nikola Tesla

\subsection{Earth as a Heat Engine}

As the quote stated, people have been thinking of utilizing geothermal energy for a long time. In fact, hot springs have been used by mankind from time immemorial. However, the commercialization of geothermal energy did not start until the first success of the geothermal power generation in Italy in 1904. Since then, with growing concerns of fossil fuels depletion and environment deterioration, geothermal energy has experienced dramatic increase in attention.

During the millions of years of the Earth's formation, the earth developed a solid inner core with a radius of 1,221-kilometers, and a liquid outer core of 2,200-kilometers, approximately. The temperature at the edge of the liquid outer core is about $4,000 \mathrm{~K}$. About $40 \%$ of the geothermal energy is from such remnant heat from the Earth's core (Glassley, 2010). The other $60 \%$ of the heat is from the radioactive decay of the long- 
lived isotopes of uranium $\left(\mathrm{U}^{238}, \mathrm{U}^{235}\right)$, thorium $\left(\mathrm{Th}^{232}\right)$ and potassium $\left(\mathrm{K}^{40}\right)$. Heat transfer in the earth, dominated by conduction and convection, results in a heterogeneous terrestrial heat flow, ranging from $30 \mathrm{~mW} / \mathrm{m}^{2}$ to more than $150 \mathrm{~mW} / \mathrm{m}^{2}$. Figure 1.1 shows the heat flow map of the continental United States by South Methodist University (SMU) Geothermal Lab (Blackwell, et al., 2011). As seen from Figure 1.1, the western region has a higher geothermal heat flow than the east region on average.

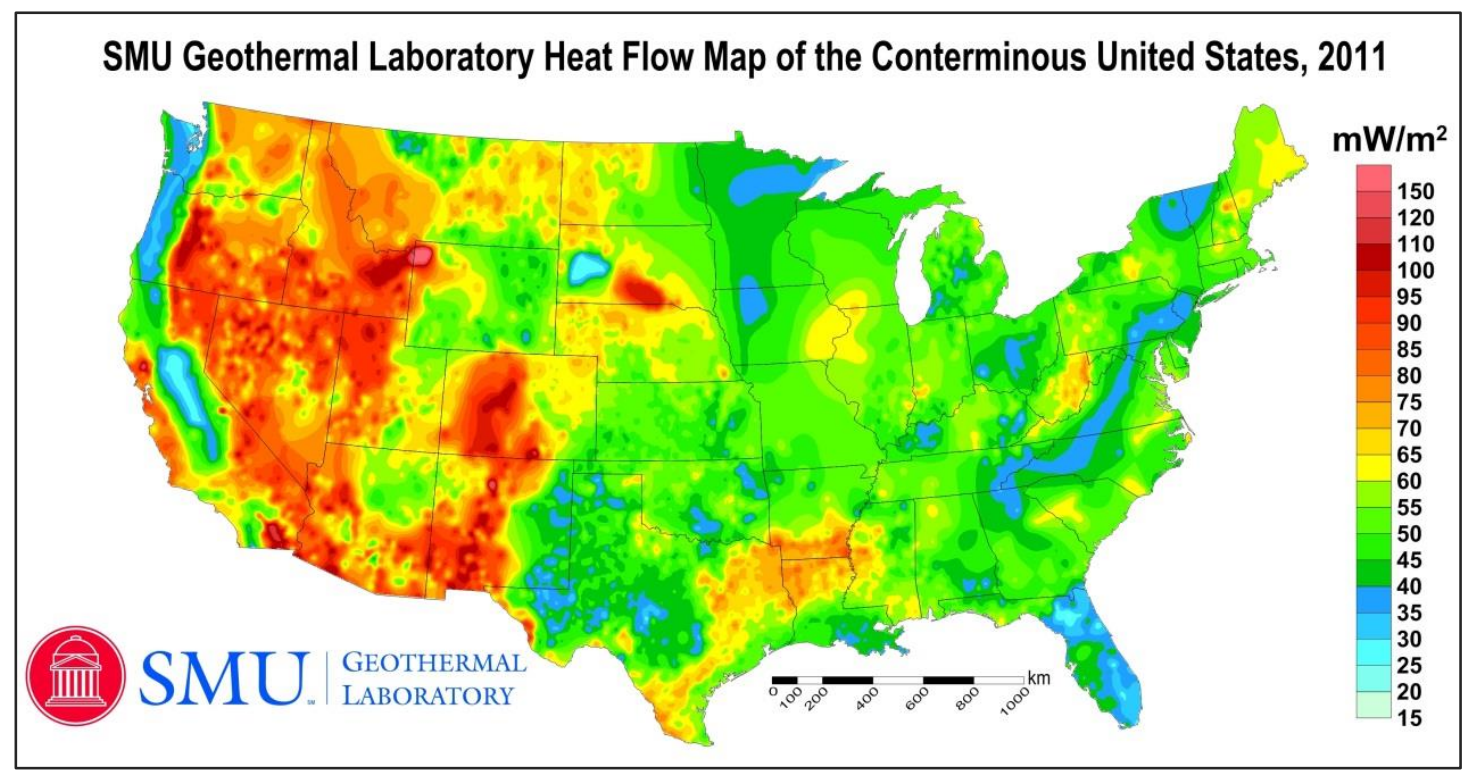

Figure 1.1: Heat flow map of the conterminous United States by SMU Geothermal Laboratory (Blackwell, et al., 2011).

\subsection{Using Geothermal Energy for Heat and Power}

Man has a long history of direct use of geothermal energy, back from when people began to use hot springs for baths, to modern geothermal utilizations, such as space heating or aquaculture farming. The classic Lindal diagram (Gudmundsson, et al., 1985) shown in Figure 1.2 provides a good overview of the geothermal utilizations based on different temperature ranges. Conventional power generation technics generally require geothermal temperatures greater than $150^{\circ} \mathrm{C}$. For a lower temperature range (110 to $150^{\circ} \mathrm{C}$ ), a binary cycle power generation is often used, which uses a secondary low boiling temperature fluid instead of water, to be vaporized and sent through a turbine. Geothermal district heating and cooling requires even lower temperatures. Given the 
ubiquity of the temperature range $\left(20\right.$ to $\left.100^{\circ} \mathrm{C}\right)$ for other low temperature cascading utilizations, direct use has the potential to be applied in most regions on the earth as long as there is a sufficient water supply and a large enough energy consumption market.

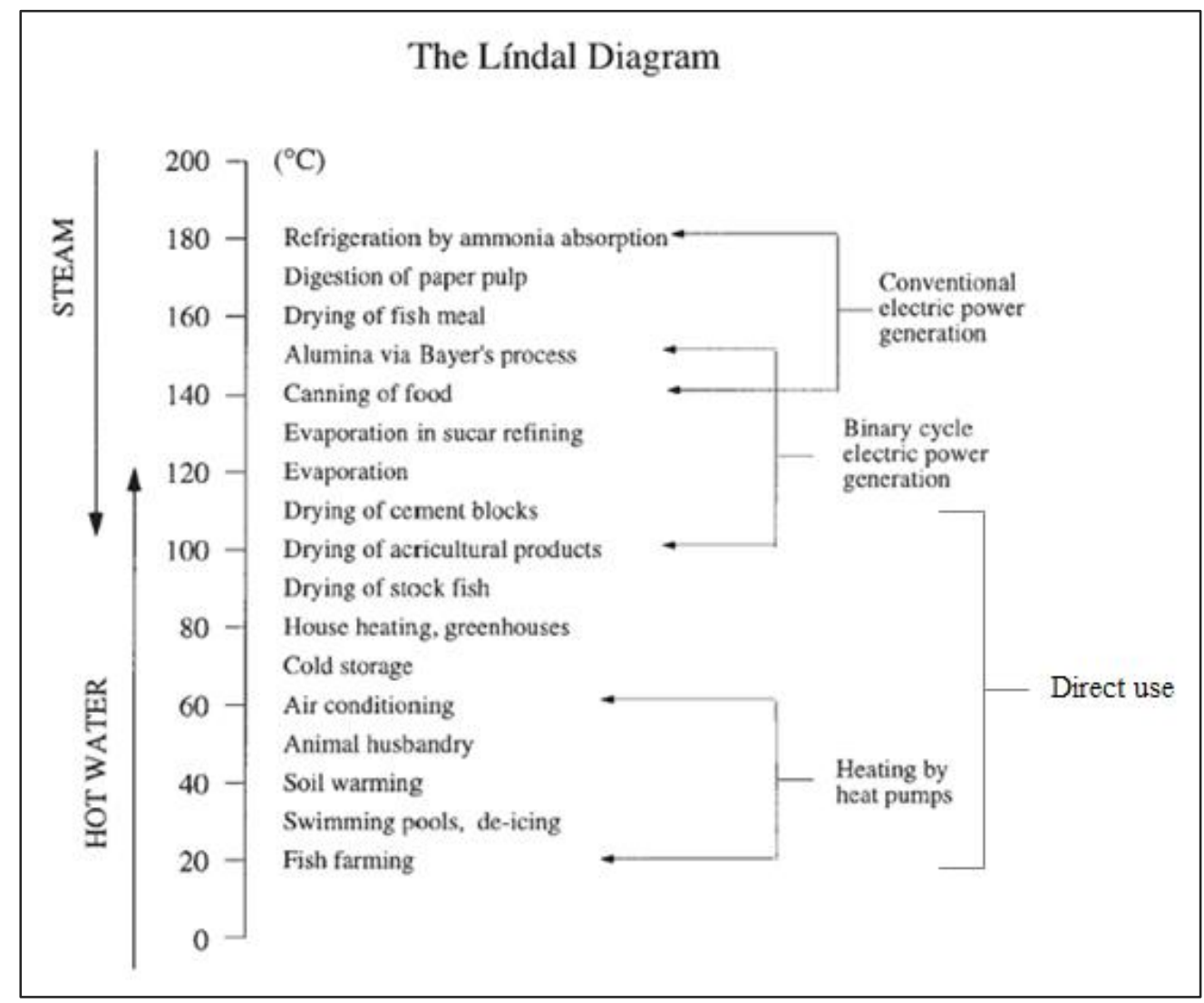

Figure 1.2: The Lindal diagram shows different geothermal utilizations by temperature ranges (Gudmundsson, et al., 1985).

Figure 1.3 shows a basic geothermal district heating and cooling (GDHC) utilization which consists of geothermal injection and production wells for hot water production, a surface energy distribution network for hot water distribution, and a surface energy conversion system for heating and cooling production. Because of the large amount of energy production and the huge capital and maintenance costs of a geothermal heating and cooling system, it would not be energetically nor economically efficient for individual users. A GDHC system should be carefully coupled with local geothermal resource availability and local energy demand to let them match one another, to ensure sufficient energy production and profits from selling energy. The monthly heating and 
cooling demand should be carefully estimated, so that geothermal energy production can be controlled, and to prevent fast reservoir cooling. Return water from a GDHC system can further be used for cascading utilizations such as snow melting or fish farming whose temperature requirements are lower.

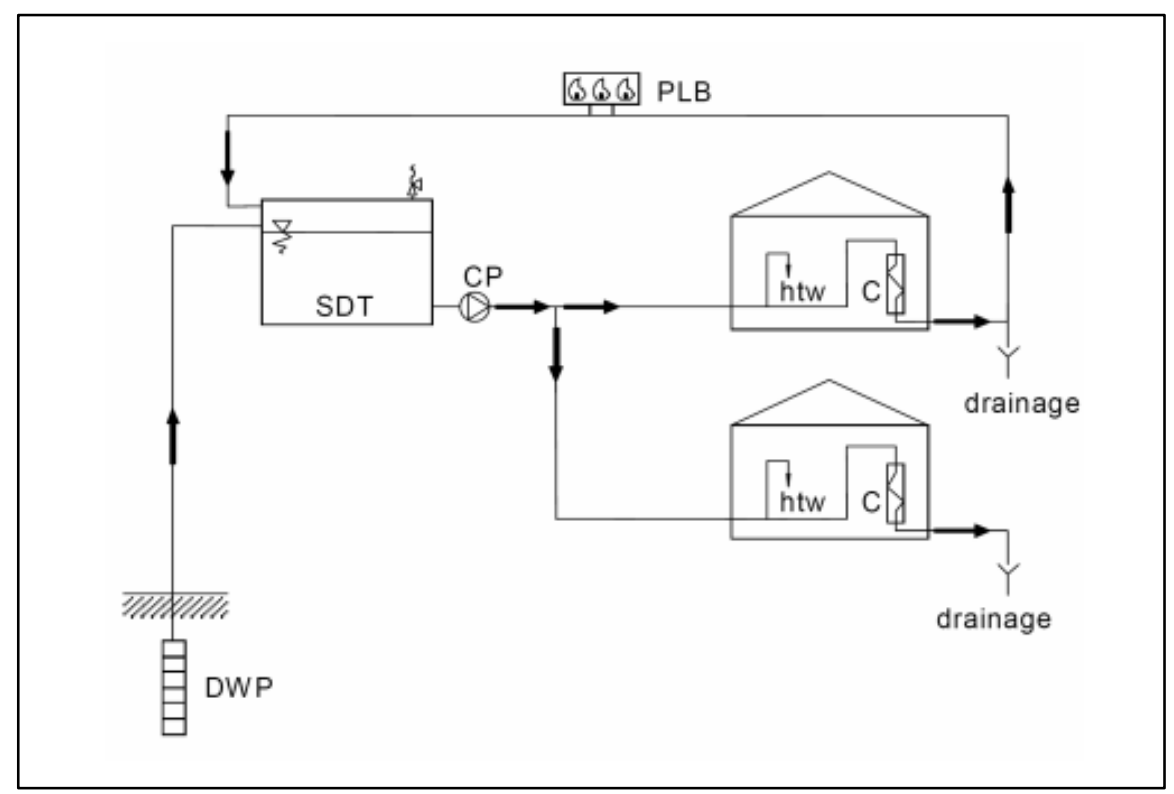

Figure 1.3: Schematic layout of a geothermal district heating and cooling system. DWP is deep well pump, SDT is storage and degassing tank, CP is circulation pump, PLB is peak load boiler, htw is hot water, and C is convention heating (Marcel, 2007).

The first geothermal power generation device was set up in Italy in 1904. After a century of development, the world installed geothermal power generation capacity has exceeded $10,000 \mathrm{MW}_{\mathrm{e}}$ in at least twenty-four countries (Chamorro, et al., 2012). Figure 1.4 shows a two-well enhanced geothermal power generation system in hot rocks in a low permeability crystalline basement formation. Similar to geothermal district heating and cooling, wells are drilled to desired depths to access the rocks which are hot enough. With respect to different production temperatures, different power generation technics will be applied. The dry steam power plant uses high quality vapor-dominated hot steam to go directly through the turbine, which requires a high-temperature geothermal reservoir. For a median temperature reservoir with a liquid-dominated production fluid, the flash steam power plant is used. A binary power plant is used when the production 
temperature is less than $150^{\circ} \mathrm{C}$. In case there is an aquifer layer underground and sufficient rock permeability, the heated geothermal water can be directly pumped to the surface, with return water from the geothermal utilization system re-injected back to the reservoir. Otherwise, artificial permeability improvement technologies should be used. Massive water fracturing is one of the most commonly used technics, which pumps millions of gallons of water into the reservoir to stimulate the rock through hydrofracturing or hydro-shearing, and forms pathways that allow water going through the reservoir to gain heat.

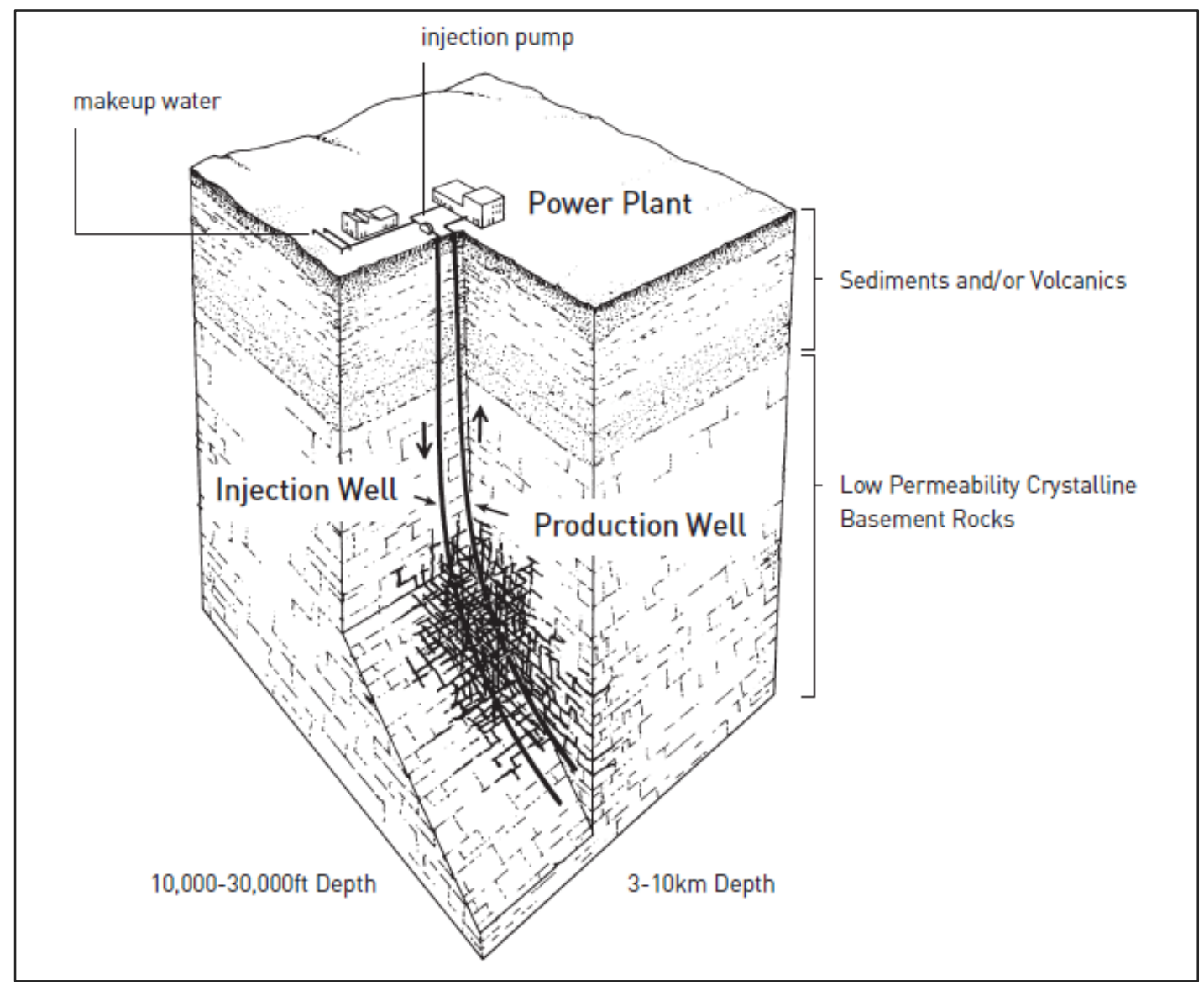

Figure 1.4: Schematic of a two-well enhanced geothermal power generation system in hot rocks in a low permeability crystalline basement formation (Tester, et al., 2006). 


\subsection{Background and Motivation}

The 20th century witnessed some of the greatest technological advancements that affect every aspect of people's daily life. Since then, fossil fuels such as coal, oil and natural gas provide people a better living condition with electricity for heating and cooling, fast methods of transportations, and various industrial products. The improved living quality results in vast increases in energy per capita use; besides, the world population has expanded more than three times in the last fifty years, as shown in Figure 1.5. As a result, the consumption of fossil fuels has increased significantly, and the depletion problem rises. Asif predicted that the number of years to the exhaustion of coal for India, China, Russia and U.S. are 315, 83, 1034 and 305 years, respectively (Asif and Muneer, 2007).

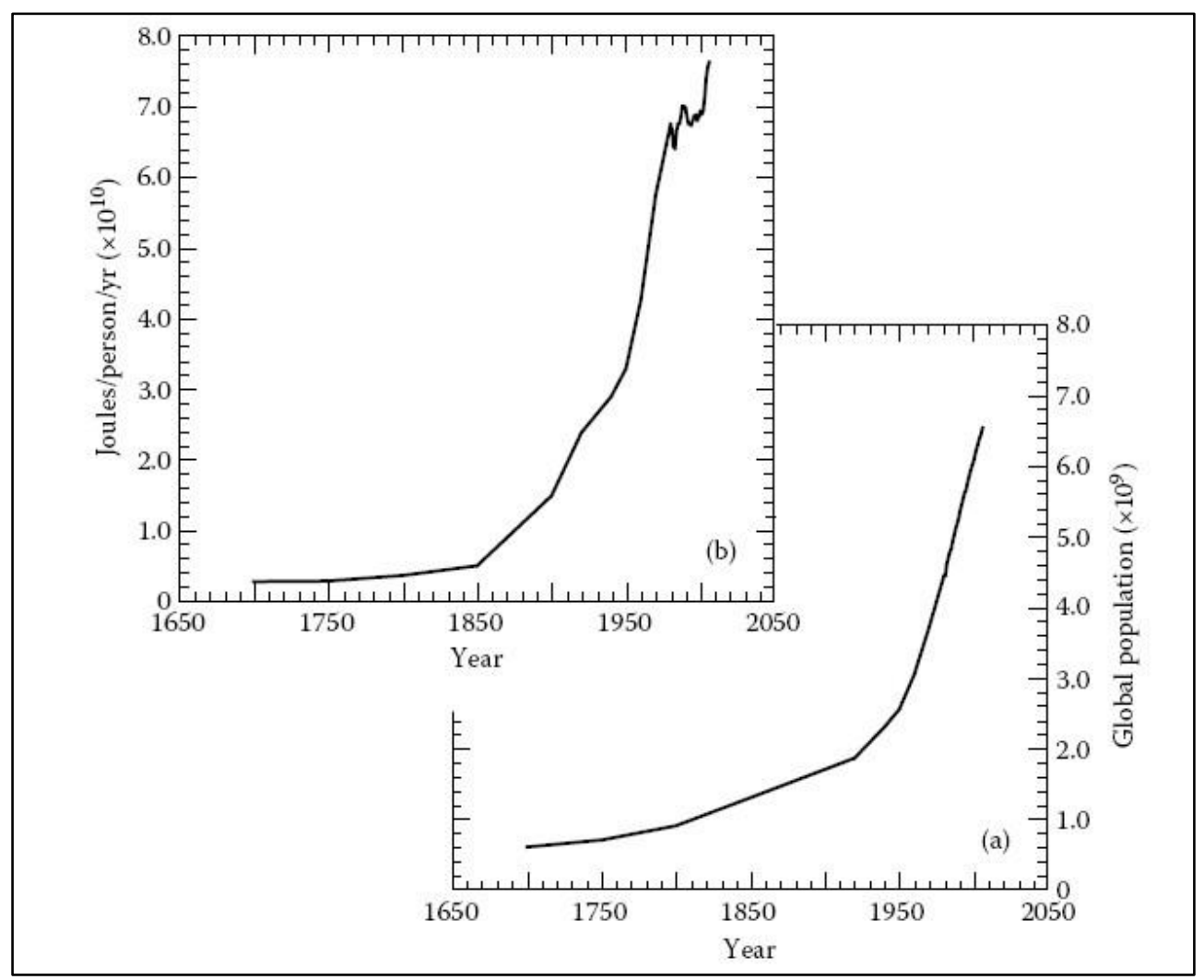

Figure 1.5: World average energy consumption per person $\left(\times 10^{9} \mathrm{~J} / \mathrm{ppl} / \mathrm{year}\right)$ and population growth since 1970, data from (Glassley, 2010).

Using geothermal energy can efficiently reduce the fossil fuels consumption on the low temperature end uses like space heating. As of 2010, the U.S. installed capacity of 
geothermal direct use reached 12,611 $\mathrm{MW}_{\mathrm{th}}$, which produced 56,552 $\mathrm{TJ}$ of thermal energy in 2010 (Lund, 2010). Annual energy savings amounted to 27 million barrels of equivalent oil, and preventing 3.5 million tonnes of carbon and 12.8 million tonnes of $\mathrm{CO}_{2}$ being released to the atmosphere, based on the data from Lawrence Livermore Laboratory (Kasameyer, 1997).

Another issue of intensively burning fossil fuels is its harm to the environment. The burning residue causes air pollution and vast greenhouse gas emission resulting in the greenhouse effect, as evidenced by elevated global temperature, polar ice melting and sea level increase (Lashof and Ahuja, 1990). Figure 1.6 shows the $\mathrm{CO}_{2}$ emission from fossil fuels (coal, oil and natural gas), corresponding to the increasing global mean temperature since 1980 to 2010.

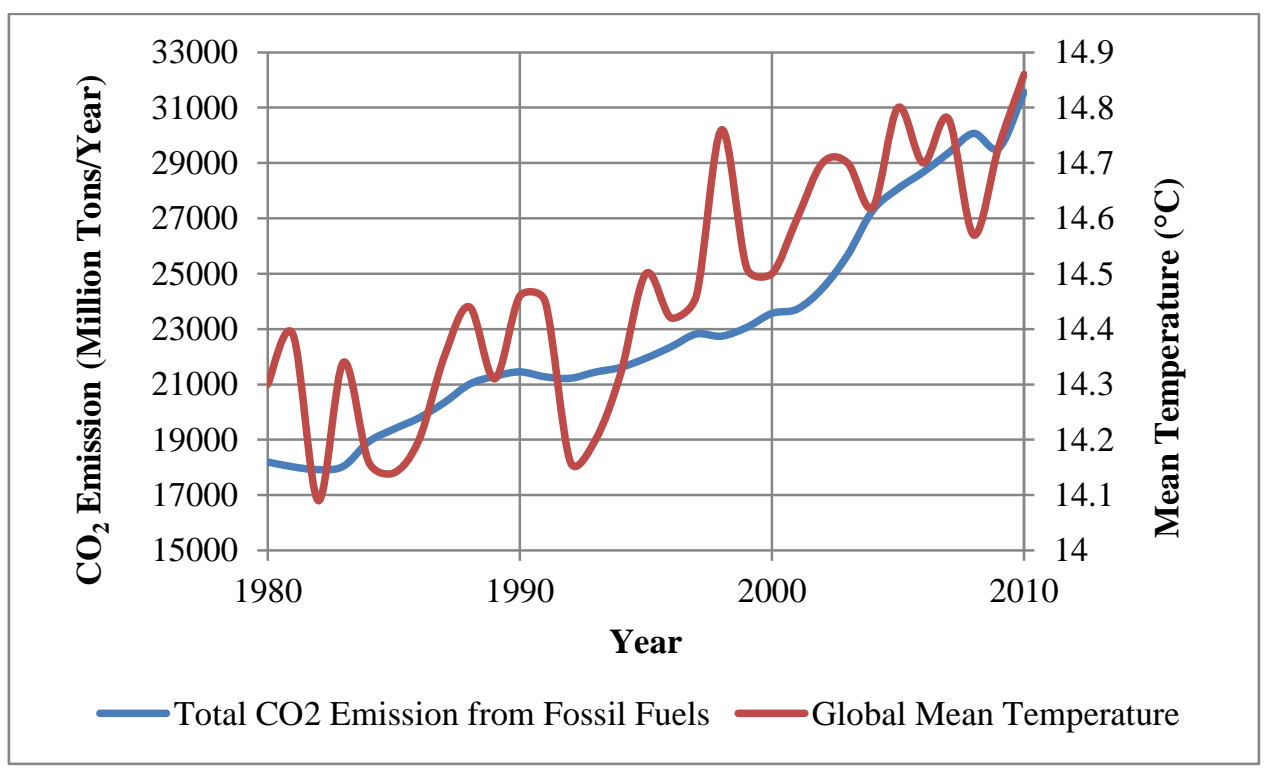

Figure 1.6: $\mathrm{CO}_{2}$ emission from fossil fuels, data from (EIA, 2011) and global mean surface temperature, data from (NASA, 2012)

\subsection{World-wide Geothermal Development}

Geothermal direct use has been growing rapidly during the last 15 years. Figure 1.7 shows the number of installed country and the total installed capacity of geothermal direct use around the world. There are 78 countries reported having geothermal direct use 
installed by the end of 2009, while the number for 1995 is only 28. The worldwide installed capacity in 2009 and 1995 is $50,583 \mathrm{MW}_{\text {th }}$ and 1,000 $\mathrm{MW}_{\text {th }}$, respectively. The five countries with the largest installed capacity are the United States, China, Sweden, Norway, and Germany. Among the overall installed capacity in 2010, the geothermal heat pump accounts for $69.7 \%$, followed by the geothermal space and water heating, which is $23.9 \%$, and the geothermal greenhouse heating, which is $3.1 \%$ (Lund, et al., 2010).

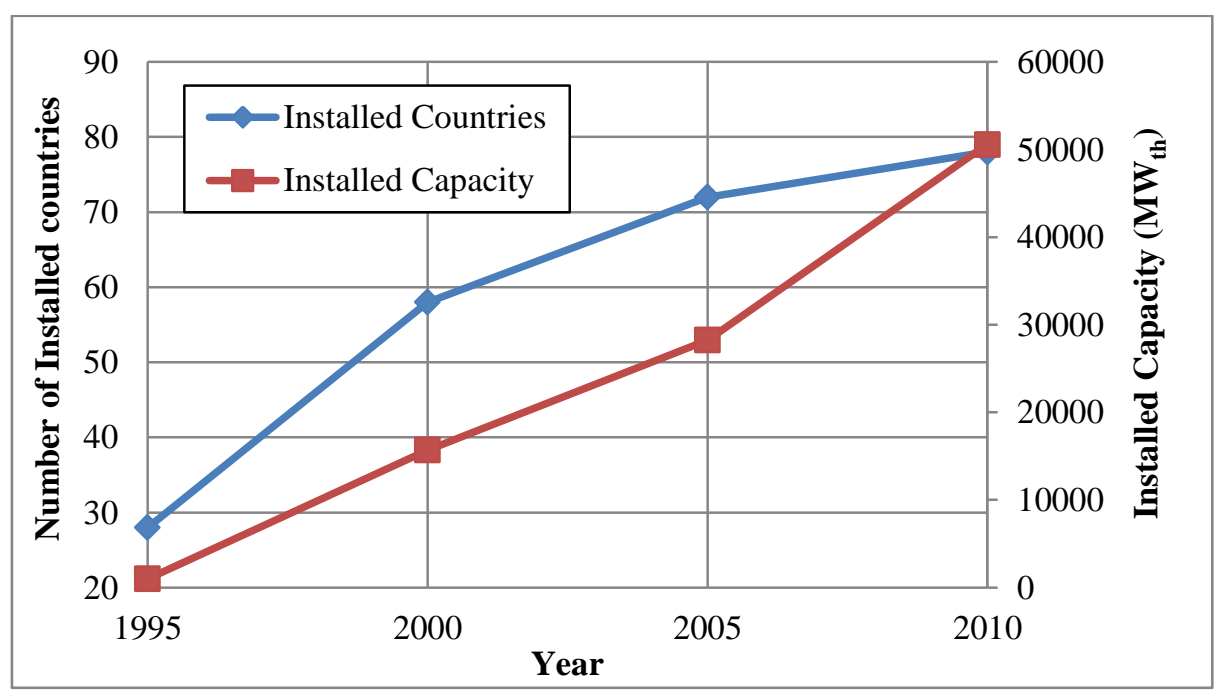

Figure 1.7: Number of installed countries and installed capacity of geothermal direct use.

As of 2012, there are 24 countries reported having geothermal power generation, with a total installed capacity about $10,898 \mathrm{MW}_{\mathrm{e}}$, corresponding to $67,246 \mathrm{GWh}$ of electricity each year. The installed capacity doubled in the last three decades, and is expected to reach 70,000 $\mathrm{MW}_{\mathrm{e}}$ worldwide by 2050 (Chamorro, et al., 2012), as shown in Figure 1.8. The five countries with the largest installed capacity are the United States, Philippines, Indonesia, Mexico and Italy. Currently geothermal power generation projects are mainly served by hydrothermal resources, and the flash steam power plant dominates the power generation technics. 


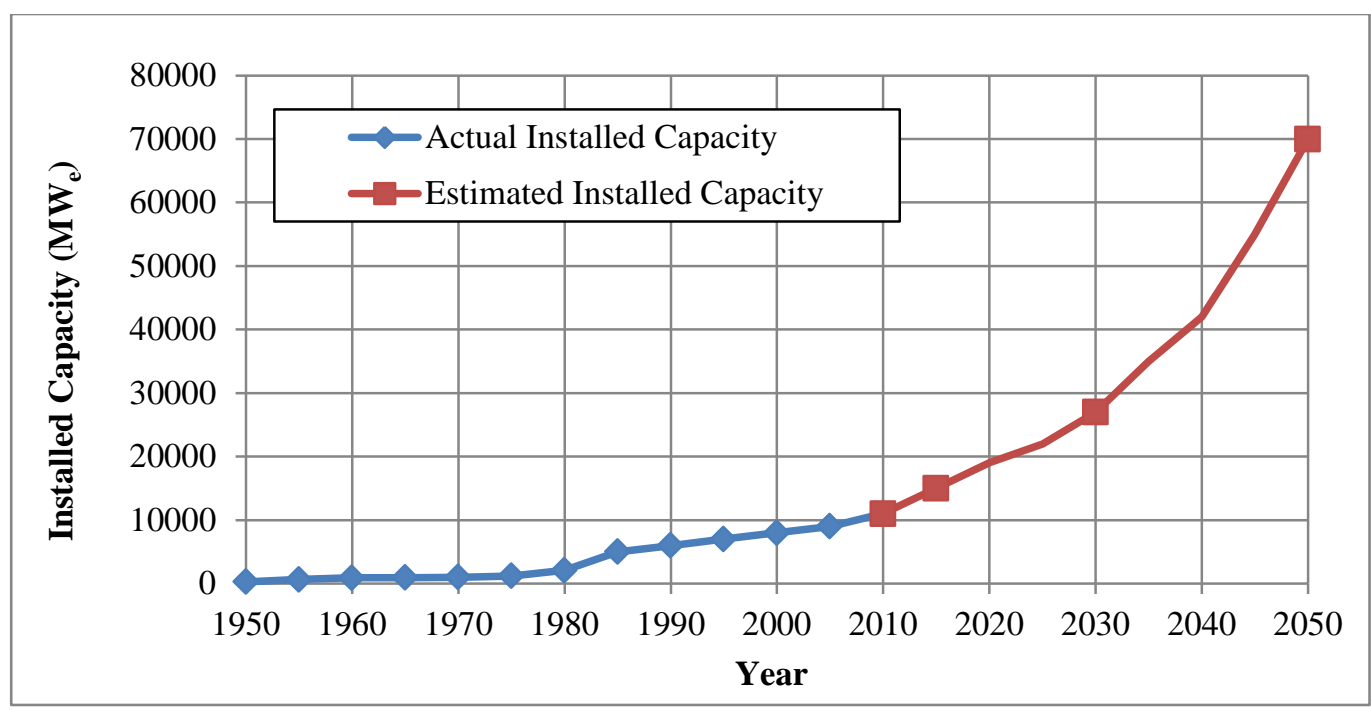

Figure 1.8: Installed capacity of the worldwide geothermal power generation since 1950 . It is expected to reach $70,000 \mathrm{MW}_{\mathrm{e}}$ in 2050.

\subsection{Objective and Approach}

This project focuses on the evaluation of the opportunities to develop the GDHC systems in the United States from the view of technical and economic feasibility. With the help of the GDHC systems, huge amounts of fossil fuels consumption and greenhouse gas emissions can be reduced, which will help the United States energy industry restructure to a more renewable and sustainable oriented supply system, and to protect the national energy security.

To accomplish this, In Chapter 2 the hydrothermal geothermal resources and near hydrothermal EGS in the western U.S. were identified, and their thermal potential estimated. Then a techno-economic model to calculate the levelized cost of heat (LCOH) of the GDHC system was developed. By estimating the $\mathrm{LCOH}$ for each of the identified resource, a supply curve of the GDHC application was finally developed, which is able to answer the questions such as how much geothermal energy can be potentially used for the GDHC systems in the United States, and where to develop such systems in order to get the minimum LCOH. In Chapter 3 a West Virginia University (WVU) case study on GDHC application based on the deep EGS resource was conducted to evaluate potential economic advantages in comparison with the current steam system. A series of LCOH 
equations which are as functions of population density at different geothermal gradients were then derived. Finally, the $\mathrm{LCOH}$ was calculated for every census tract in West Virginia to develop the GDHC system. Those census tracts with the lowest LCOH were found and mapped by ArcGIS. Chapter 4 briefly provides conclusions and recommends future works for the development and research of the GDHC application. 


\section{Chapter 2}

\section{Supply Analysis of Geothermal District Heating and Cooling Systems}

\subsection{Introduction}

Supply analysis reveals the relation between a given good's price and its quantity in modern market. The supply curve is the most straightforward way to illustrate the supply analysis results. A typical supply curve usually has a positive slope, which means that at a low price, only the most efficient producers can make a profit, with limited product amount; at a high price, even the high cost producer can also make a profit, and hence large amount of products available.

Supply analysis has been accepted as a powerful tool in both traditional and renewable energy research for estimation of energy reserves, as well as for the cost of energy, e.g. Analysis on the oil market by Blair (Blair, 1978) and Kilian (Kilian, 2006), coal market by Gordon (Gordon, 1975), and solar energy market by Cook, et al. (Cook, et al., 2010). Supply analysis has also been used for geothermal energy research since the 1990s. There are two main applications of geothermal energy, which is power generation and direct use, however, all the supply analysis have only been concentrating on the geothermal power generation, e.g. (Petty, et al., 1992 and 2007) and (Augustine, et al., 2010). In the light of the foregoing, the first aspect of this study is the supply analysis of a nationwide geothermal direct use. It answers the following two questions: How much geothermal energy is available for the geothermal district heating and cooling application and how much it costs to deliver the energy in respect of the first question. The other aspect of this study is to map the paired energy potential and energy cost, and it answers another question: where to develop the geothermal district heating and cooling application first with concerns of the energy adequateness and economical costs. Answers to these 
questions help to develop a comprehensive national renewable energy strategy and framework with respect to geothermal energy and also address the economic environmental balance issue.

\subsection{Levelized Cost of Heat}

Traditional supply curve consists of two parts: the $\mathrm{x}$-axis represents the accumulated quantity of the good in the market and the y-axis represents the price at which can make a profit. An example is shown in Figure 2.1, which shows the wind power's supply curve in Zhangbei area, China. In this study the quantity of the good is simply the geothermal energy potential, which is directly related to the geothermal resources' quality and quantity. However, how to define the "price" that can make a profit is more complicated. The basic economics tells that the selling price should at least cover all the investments in the producing process. The geothermal energy is an extremely capital-intensive industry with three capital investment phases: 1) Exploration and drilling of test and production wells; 2) Construction of surface energy conversion facilities; and 3) Discounted future re-drilling and well simulation (Tester, et al., 2006). How to find the optimum price which is related to both the one-time upfront investments and the various day-to-day operation costs over the project's lifetime is very important. The geothermal energy industry is also very location-sensitive. The quality of the resources has a significant impact on the wells drilling and completion costs, which attribute up to $60 \%$ of the overall capital investments (Sanyal, 2004). Even for the resources with similar geologic settings, differences in energy demand and energy market structure also impact. Therefore, the levelized cost of heat $(\mathrm{LCOH})$ is used in this study, which is a convenient summary measure of the competitiveness of one energy generating technology. It represents the present value of the overall cost to build and operate an energy generating plant over the project's lifetime. 


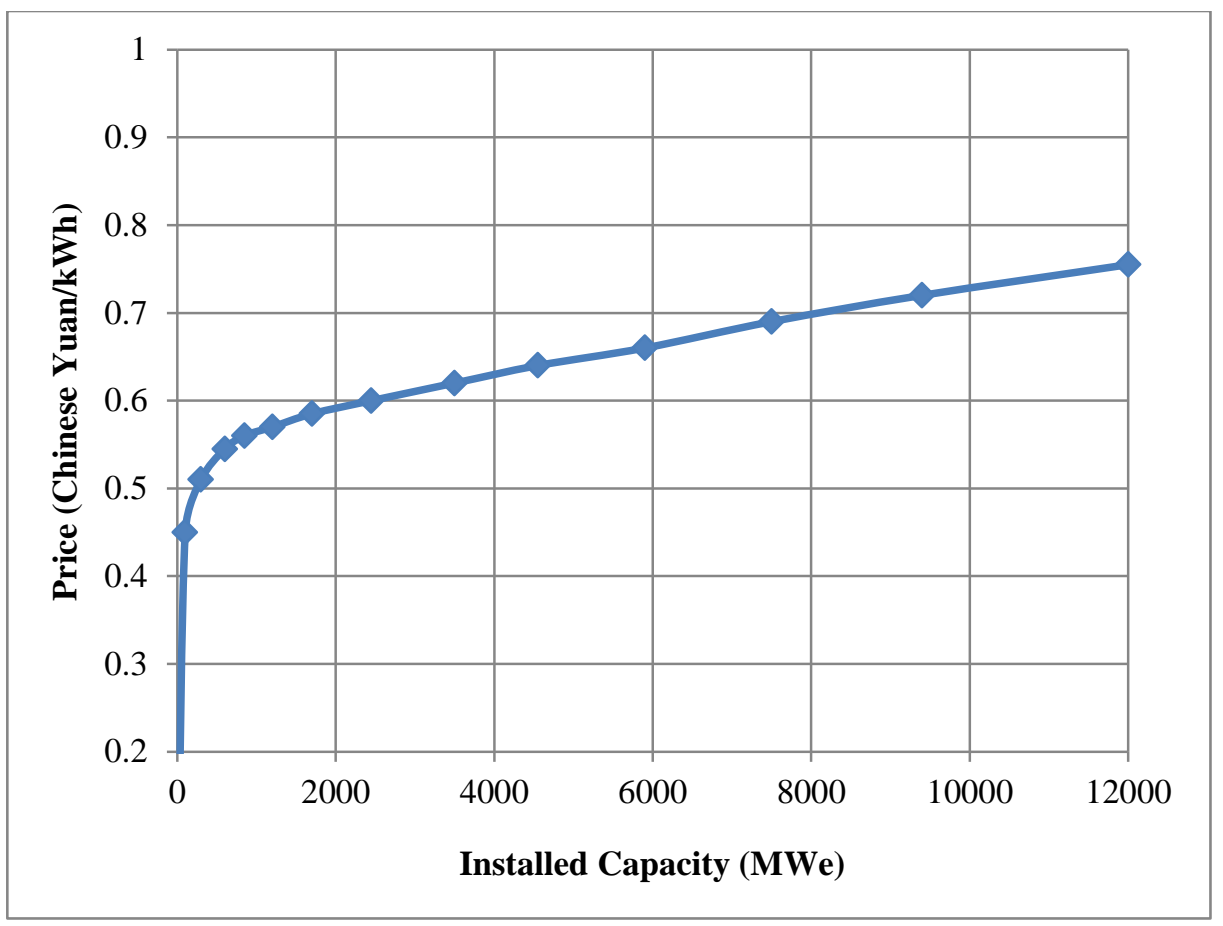

Figure 2.1: Zhangbei area, China available wind power supply, plotted based on data from Kline, et al., 2008.

The LCOH is related to the system's capital cost, fuel cost, fixed and variable operation and maintenance $(\mathrm{O} \& \mathrm{M})$ cost, financing cost, and so on. For one kind of energy resource, the specific technology used converting it to power or heat and the regional characteristics such as the resource availability and energy consumption market are also key elements for the $\mathrm{LCOH}$ calculation. Figure 2.2 shows the predicted levelized cost of electricity (LCOE) and their cost breakdown for different technologies in the U.S. in 2019. It shows that for electricity generation, geothermal energy is very competitive to other forms of energy resources because of its advantages of the high capacity rate, long project lifetimes with a stable base load output and near zero fuel cost. 


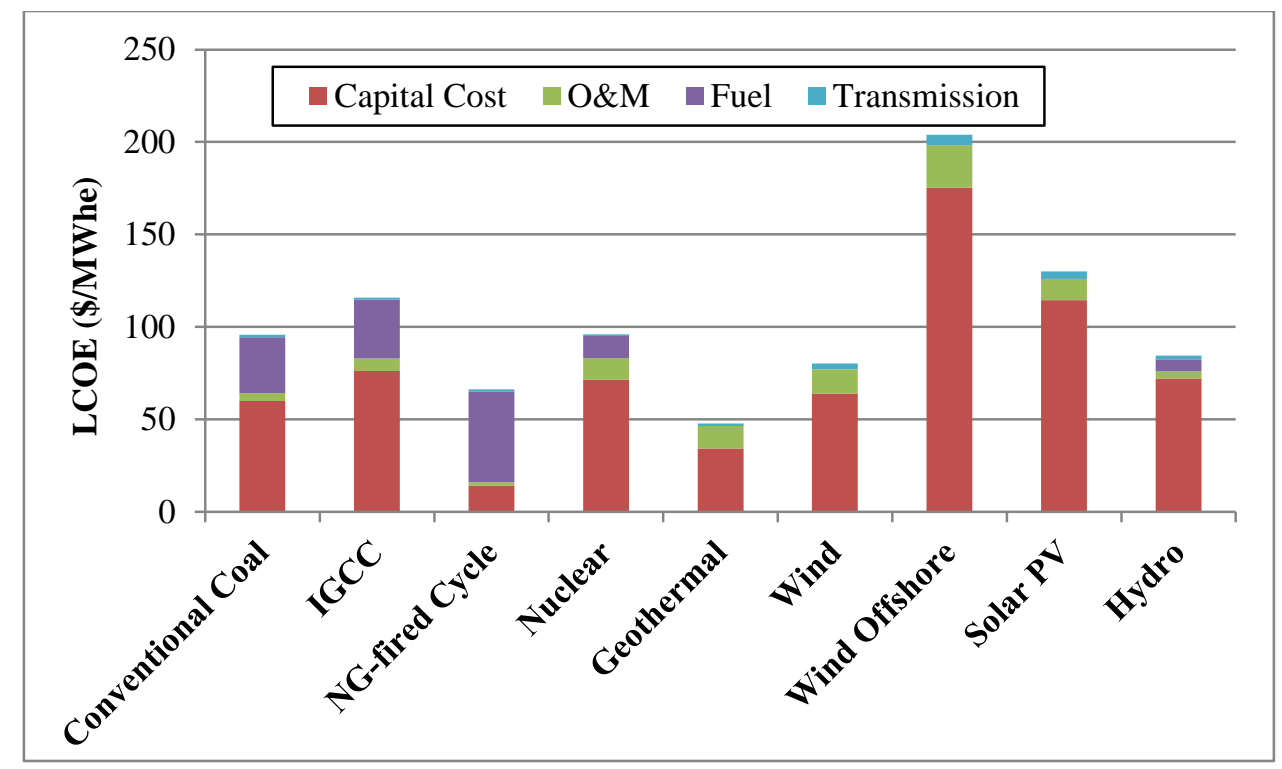

Figure 2.2: Predicted levelized cost of electricity and cost breakdown for new generation resources in 2019, based on data from Annual Energy Outlook, 2014, U.S. EIA.

In this study, an Excel-based calculation model was developed to calculate LCOH of the GDHC system. The model can provide a comprehensive simulation of the proposed system, and help the designers, engineers, operators and utilities with extensive technical and economic information about the GDHC system. The model uses a matrix of about 20 user-defined variables to cover every aspect of the system. In general categories, the variables account for geothermal resource characteristics, wells exploration and production, market configuration, heating/cooling facilities, and economic settings. The output results provide a year-round monitoring of the geothermal production temperature, flow rate, and the overall energy production, as well as economic analysis throughout the project's lifetime.

\subsection{Previous Studies on Geothermal Supply Analysis}

Previous work on supply analysis of geothermal energy have only been focused on geothermal power generation, e.g. Petty, et al., 1992 and 2007, and Augustine, et al., 2010. As time goes on, more geothermal exploration activities, as well as more advanced energy utilization technology have been developed. Thus, the latter report has covered more categories of geothermal resources than the former ones with lower estimated cost. 
A summary including the estimated power potential and their corresponding levelized cost of electricity from these reports is listed in Table 2.1.

Table 2.1: Summary of geothermal power potential and levelized cost of electricity from previous supply analysis studies.

\begin{tabular}{|c|c|c|c|c|c|}
\hline Source & Category & $\begin{array}{c}\text { Potential, } \\
\qquad \mathrm{GW}_{\mathrm{e}}\end{array}$ & Region & $\begin{array}{l}\text { Cost } \\
\text { Model }\end{array}$ & $\begin{array}{c}\text { Potential, } \\
\mathrm{GW}_{\mathrm{e}} \text { less than } \\
\$ 50 / \mathrm{MWh}\end{array}$ \\
\hline \multirow{2}{*}{$\begin{array}{l}\text { Petty, et } \\
\text { al., } 1992\end{array}$} & $\begin{array}{c}\text { Identified } \\
\text { hydrothermal }\end{array}$ & 27.4 & \multirow{2}{*}{ Western U.S. } & \multirow{2}{*}{ IM-GEO } & 12.5 \\
\hline & $\begin{array}{l}\text { Undiscovered } \\
\text { hydrothermal }\end{array}$ & 22.6 & & & 9.5 \\
\hline \multirow{3}{*}{$\begin{array}{c}\text { Petty and } \\
\text { Porro, } \\
2007\end{array}$} & Hydrothermal & 27.6 & \multirow{3}{*}{$\begin{array}{c}\text { Western U.S. } \\
\qquad \& \\
\text { Southwestern } \\
\text { U.S. for } \\
\text { coproduced }\end{array}$} & \multirow[b]{3}{*}{ GETEM } & $<10.0$ \\
\hline & EGS & 54.7 & & & 0 \\
\hline & $\begin{array}{l}\text { Co-produced } \\
\text { with oil, gas }\end{array}$ & 44.0 & & & 21.0 \\
\hline \multirow{4}{*}{$\begin{array}{l}\text { Augustine, } \\
\text { et al., } 2010\end{array}$} & $\begin{array}{c}\text { Identified } \\
\text { hydrothermal }\end{array}$ & 6.4 & \multirow{4}{*}{$\begin{array}{c}\text { Western U.S. } \\
\text { \& entire } \\
\text { lower } 48 \\
\text { states for } \\
\text { EGS }\end{array}$} & \multirow{4}{*}{$\begin{array}{c}\text { GETEM } \\
\& \\
\text { @ Risk }\end{array}$} & 3.0 \\
\hline & $\begin{array}{l}\text { Undiscovered } \\
\text { hydrothermal }\end{array}$ & 30.0 & & & 0 \\
\hline & $\begin{array}{c}\text { Near-hydro } \\
\text { EGS }\end{array}$ & 7.0 & & & 2.5 \\
\hline & Deep EGS & $15,908.0$ & & & 0 \\
\hline
\end{tabular}

The first report was published in 1992, in which Petty et al. reviewed 54 hydrothermal resources in the western U.S. The report focused only on eleven western states, which were Arizona, California, Colorado, Hawaii, Idaho, Nevada, New Mexico, Montana, Oregon, Utah, and Washington. The report identified 45 hydrothermal resources in these states where surface manifestation such as hot springs or geysers or if a well had been drilled into the resources were observed and other 9 unities representing the undiscovered 
resources in the nine states, except Arizona and Hawaii. The report also cut off the database with a minimum reservoir temperature at $110^{\circ} \mathrm{C}$, because at that time the coolest geothermal water used for power generation was $108^{\circ} \mathrm{C}$, by a power plant in Amedee, California. The characteristics of the geothermal resources were mainly from two sources: the U.S. Geologic Survey (USGS) Circular 790 (Muffler and Guffanti, 1979), and the Bonneville Power Authority study (Bloomquist, 1985). Three parameters were selected to define a geothermal resource, which were the reservoir temperature, reservoir depth, and flow rate. Due to the extreme lack of exploration activities and data, power potential and the corresponding levelized cost were roughly estimated. Extensive personal knowledge and judgments from the investigation team and consulted experts had been used. Cost estimations were made with the use of IM-GEO, a cost model specifically developed for the geothermal power generation by a team led by Dan Entingh (Entingh, et al., 1988) in late 1980s. As a result, the report estimated $27.4 \mathrm{GW}_{\mathrm{e}}$ from the identified hydrothermal resources, and $22.6 \mathrm{GW}_{\mathrm{e}}$ from the undiscovered hydrothermal resources. The majority of the identified resources could provide electricity at a cost less than \$120/MWh. About half of the undiscovered ones could provide electricity at a cost less than $\$ 75 / \mathrm{MWh}$. The cost estimation only examined the economic feasibility of the resource itself. Political, environmental, regulatory and market constrains were not considered in this report.

In 2007, Petty and Porro updated the supply analysis of geothermal power generation with expanded geothermal resources and a new cost model the - Geothermal Electric Technology Evaluation Model (GETEM), developed by Princeton Energy Resources International (Petty and Porro, 2007). GETEM is an Excel-based techno-economic analysis tool for computing costs for a set of user-defined input variables that address four dozen project criteria based on a baseline profile of the input values that reflect current technical capabilities and economic conditions (Entingh, 2006). The updated supply analysis covered not only the hydrothermal resources, but also the enhanced geothermal systems (EGS) and the geothermal fluid coproduced in oil and gas industry. The updated report also expanded its focus to 12 more southeastern states (mainly for coproduced geothermal system), which were Alabama, Arkansas, Georgia, Kansas, Louisiana, Mississippi, North Carolina, Oklahoma, South Carolina, Tennessee, Texas, and Virginia. The study extensively reviewed and investigated the geothermal resources 
based on more than 10 reports from the USGS (Priest, et al., 2000), state geologic survey office (Garside, 1994), SMU Geothermal Lab (Blackwell and Richards, 2004), and private firms such as GeothermEx (Klein, et al., 2004), and identified more than 220 hydrothermal and convective EGS sites. By collecting the physical characteristics of the resources, and with the advantage of the GETEM, the updated supply analysis estimated the levelized cost of electricity based on resource types (Hydrothermal or EGS) and utilization technologies (binary or flash). Methods for potential estimation were similar to the previous one, by assuming a series of constant conversion rate to get the power potential from the original heat stored in the reservoir, which is called the Volume Method. As a result, they estimated $27.6 \mathrm{GW}_{\mathrm{e}}$ from the hydrothermal resources, $44 \mathrm{GW}_{\mathrm{e}}$ from the coproduced resources, and $54.7 \mathrm{GW}_{\mathrm{e}}$ from the EGS resources. The levelized cost of electricity was estimated at least $\$ 40 / \mathrm{MWh}$, and that of over $90 \%$ of the resources were less than $\$ 80 / \mathrm{MWh}$. Another improvement comparing to the previous supply analysis was that they introduced the impacts of geothermal industry's R\&D and learning ability. The updated report not only gave economic analysis based on year 2007, but also predicted the cost of energy in year 2015 and year 2030 with advanced technology.

In 2010, Augustine, et al. reviewed any possible available reports and papers to estimate the geothermal power potential, in particular, the most recent national geothermal assessment conducted by USGS (Williams, et al., 2008) and the Future of Geothermal Energy report from Massachusetts Institute of Technology to characterize the EGS resources (Tester, et al., 2006). The study identified 241 hydrothermal resources, and gave reasonable guesses for the undiscovered resources, and it for the first time covered all the continental U.S. (48 states) for the EGS resources. Methods for power potential and cost of energy estimation remained similar with the former studies. The most significant improvement was that more effort had been focused to predict the cost decrease due to different levels of funding. The study adopted a possible data range for each system's technology performance metric from the updated geothermal technical risk assessment (Young, et al., 2010), and gave probabilistic results of the power potential as well as the LCOE. As a result, Augustine et al. estimated $36.4 \mathrm{GW}_{\mathrm{e}}$ from the hydrothermal resources, and 15,915 $\mathrm{GW}_{\mathrm{e}}$ from the EGS resources, of which $7 \mathrm{GW}_{\mathrm{e}}$ is near hydrothermal EGS. Estimation of EGS resources covered much larger area than any 
other study, with 48 states from underground $3 \mathrm{~km}$ to $10 \mathrm{~km}$, while Petty and Porro, 2007 only covered eleven western states from $3 \mathrm{~km}$ to $6 \mathrm{~km}$. The levelized cost of electricity was estimated at least \$30/MWh, and that of the most of the undiscovered hydrothermal resources were less than $\$ 100 / \mathrm{MWh}$. Developments for the most of the EGS resources were predicted to be not economically feasible.

Besides the above mentioned cost models IM-GEO, and GETEM (continuing being updated by National Renewable Energy Laboratory, latest version is August 2012 Beta), there have been several other models developed by national laboratories or universities for the same purpose, such as the System Advisor Model (Gilman and Bobos, 2012), and the Cost of Renewable Energy Spreadsheet Tool (Gifford and Grace, 2011) from U.S. National Renewable Energy Laboratory, the HEATMAP ${ }^{\odot}$ from the Washington State University Energy Program and the software for direct use applications from Geo-Heat Center, Oregon Institute of Technology. However, none of these cost models consider reservoir characteristics impacts on the energy cost except GETEM, which was specifically designed for geothermal power generation. Therefore, a new cost model comprehensively considering the reservoir characteristics and the surface utilities for geothermal direct use is in need, and is developed in the present study.

No study is being conducted on the supply analysis of other geothermal applications currently. There are case studies based on specific GDHC or GDH systems, e.g. He and Anderson's case study on West Virginia University (He and Anderson, 2012), Erdogmus, et al. and Yildirim, et al.'s studies on Izmir Institute of Technology (Erdogmus, et al., 2006), (Yildirim, et al., 2006), and Lei and Valdimarsson's case study on the district heating system in Tianjing area, China (Lei and Valdimarsson, 2009), but lack of a national supply characterization of such application. This study focuses on the approach to characterize the supply curve of geothermal district heating and cooling systems in the United States. In this project, geothermal resources were categorized; resources characteristics were identified; resources' thermal potential and corresponding cost of energy were estimated; finally, the supply curve was generated. Though focusing on different types of utilization, the supply analysis of geothermal power generation gives reasonable assumptions on the market settings and provides inspiring methods for 
reservoir characterization. Some of them were adopted in this study for the supply analysis of geothermal district heating and cooling. The innovation of this study is to expand the supply analysis into the GDHC application, and for the first time to include energy market in the geothermal research.

\subsection{Reservoir Characterization and Potential Estimation}

Figure 2.3 shows the flow diagram to develop the supply curve in this study. The primary steps include the resources characterization and cost estimation. The following discusses how geothermal energy is categorized, how the reservoir is characterized and how the potential is estimated for each category of the resources.

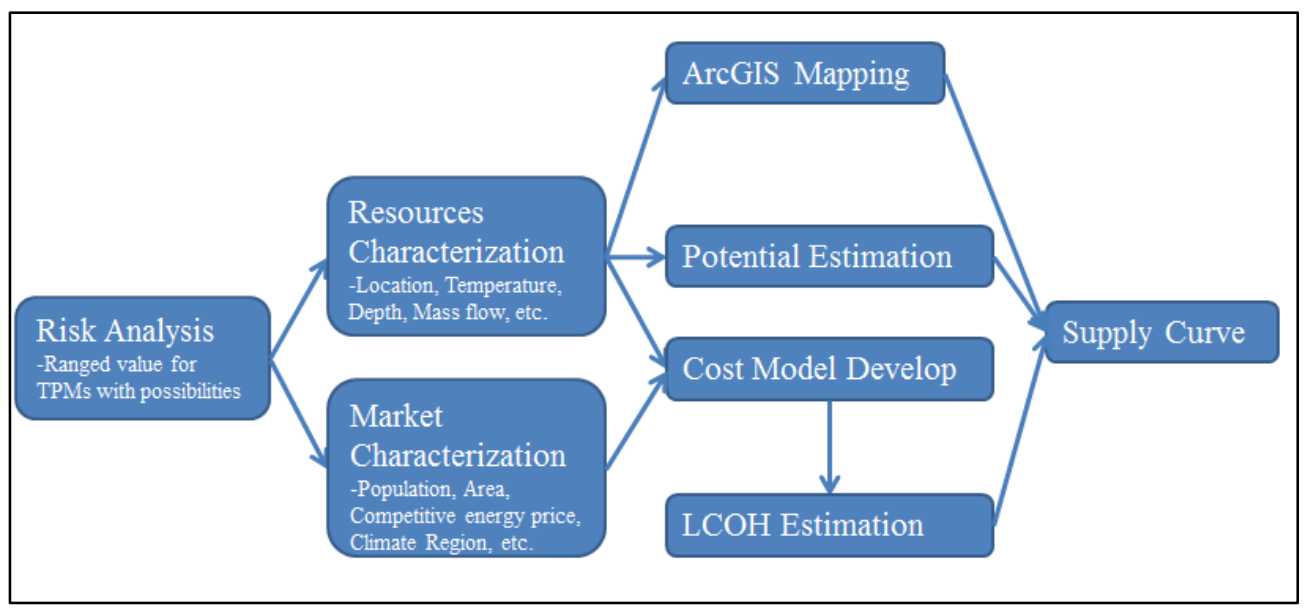

Figure 2.3: Flow diagram to develop the supply curve of GDHC application.

\subsubsection{Geothermal Resources Categorization}

For a long time, the geothermal resources were classified by their reservoir temperatures into low, intermediate, and high enthalpy resources (Lee, 1996). However, it cannot illustrate the significant reservoir differences regarding to the permeability and porosity in the geothermal research. In this study, the geothermal resources were categorized by the reservoir technology into two kinds, which are the conventional hydrothermal resources and the enhanced geothermal systems (EGS). Hydrothermal resources have the common ingredients of water (hydro) and heat (thermal). The ground water trapped in 
porous rocks or the running water along the fractured rock surfaces and faults is heated by the hot magma near the earth surface. Some of the hydrothermal resources can be observed directly, like the hot springs and the geysers. Others can be accessible by drilling wells into the reservoir. Hydrothermal resources were further classified into the identified ones and the undiscovered ones. EGS resources are also known as the hot dry rock (HDR) resources, which indicate that although hot, these resources lack sufficient permeability for energy extraction. Reservoir stimulation technologies are usually used to enhance the reservoir permeability for practical applications. EGS resources were further classified into the near hydrothermal EGS resources and the deep EGS resources in this study. Due to lack of available data for deep EGS resources, the following only discusses the first three categories of the geothermal resources.

\subsubsection{Identified Hydrothermal Resources}

Since GDHC shares the same reservoirs with geothermal power generation, the latest national assessment of geothermal power potential USGS Fact Sheet 2008-3082 (Williams, et al., 2008) was consulted. It identified 241 moderate (90 to $150^{\circ} \mathrm{C}$ ) and high temperature (greater than $150^{\circ} \mathrm{C}$ ) hydrothermal resources located in thirteen western states: Arizona, California, Colorado, Idaho, Montana, New Mexico, Nevada, Oregon, Utah, Washington, Wyoming, Alaska, and Hawaii. This study also identified twelve more low temperature (less than $90^{\circ} \mathrm{C}$ ) hydrothermal resources because of the versatile design temperatures of various heating/cooling systems by consulting other reports such as USGS Circular 726 (White and Williams, 1975), USGS Circular 790 (Muffler and Guffanti, 1979), and USGS Circular 892 (Reed, 1982). The reservoir temperature and depth data used in the study were from in situ measurements in exploration and production wells when available, or from calculation of the chemical geothermometers. Chemical geothermometers are based on the concept that chemical or isotopic constituents in the water are established at higher temperatures, but will persist when the water cools as it flows to the surface (Karingithi, 2009). Equation 2.1 shows the equation of K-Mg chemical geothermometer used by the USGS assessment (Giggenbach, et al., 1988), where $T_{R}$ is the reservoir temperature, and $c_{\mathrm{K}}$ and $c_{\mathrm{Mg}}$ are the molar concentration 
of the potassium and magnesium in the production water. The reservoirs' temperatures and depths data were retrieved from the USGS Energy Data Finder.

$$
T_{R}=\frac{4410}{14.0+\log \left(c_{K}{ }^{2} / c_{M g}\right)}-273.15
$$

Estimation of intensive properties such as temperature is usually easier than that of extensive properties such as flow rate. Without actual wells drilled, it is not possible to give an estimate. The method to determine each reservoir's mass flow rate in this study was derived from the Volume Method, as shown in Equation 2.2. The Volume Method was used in the past USGS assessments for geothermal power potential (Nathenson, 1975), (Muffler and Cataldi, 1978), (Muffler, 1979), (Lovekin, 2004), and (Williams, 2004). Equation 2.2 illustrates the process by which thermal energy stored underground is converted to electricity production:

$$
\dot{W}_{e}=\frac{\eta_{e}}{t} \times\left[R_{g}(\rho C V)_{r o c k}\left(T_{R}-T_{0}\right)-m_{W H} T_{0}\left(s_{W H}-s_{0}\right)\right]
$$

In this equation, $t$ is the lifetime of the project (typically assumed 30 years); for each reservoir, $\rho C$ is the volumetric specific heat of the reservoir rock; $V$ is the volume of the reservoir; $T_{R}$ is the reservoir temperature; $T_{0}$ and $s_{0}$ is the temperature and the entropy per unit mass of water at reference state; $m_{W H}$ is the overall mass of production water, $s_{W H}$ is the entropy per unit mass of water at the well head; $R_{g}$ represents the fracture of heat recovered from the rock; and $\eta_{e}$ represents the overall utilization efficiency from exergy to electricity. It is assumed that for an identified hydrothermal reservoir, $m_{W H}$ obtained at the well head during the lifetime depends only on the volume of the reservoir $V$. With larger reservoir volume, the fractures in the reservoir are larger, allowing more flow rate of water going through the reservoir. Thus, for any reservoir with temperature $T_{R}$ given, the power potential $\dot{W}_{e}$ depends only on the mass of water $m_{W H}$. The Volume Method illustrates the theoretical basis of how the potential is calculated in the cost model GETEM. Equation 2.3 was used in this study to find the mass flow rate by GETEM, with 
power potential and reservoir temperature data retrieved from the USGS Energy Data Finder for each resource:

$$
\dot{m}_{R}=\frac{m_{W H}}{t}=\frac{\operatorname{GETEM}\left(\dot{W}_{e}, T_{R}\right)}{t}
$$

The thermal potential $\dot{Q}$ was calculated by Equation 2.4 for each resource by assuming the return temperature $T_{r}$ at $40^{\circ} \mathrm{C}$.

$$
\dot{Q}=\dot{m}_{R} \times C_{\text {water }} \times\left(T_{R}-T_{r}\right)
$$

\subsubsection{Undiscovered Hydrothermal Resources}

Due to uncertainties of locations of the undiscovered hydrothermal resources, there is no way to estimate them one by one. This study used an analogous method as in the geothermal power generation supply analysis, as shown in Equation 2.5. The preferred geologic conditions or manifestations of undiscovered hydrothermal resources are the same with those of the identified hydrothermal resources. For example, from the studies of the known geothermal systems, young felsic magmatism has a strong spatial correlation with geothermal energy (Smith and Shaw, 1979); higher underground heat flow is usually relevant to a larger possibility of geothermal reservoir occurrence; all the quaternary faults have a strong statistical significance for the correlation within $4 \mathrm{~km}$ distance of geothermal occurrences (Williams and DeAngelo, 2008). Therefore, it is safe to use the spatial correlations of such preferred geologic factors that facilitate the formation of geothermal resources to estimate undiscovered resources. The favorability factor $\alpha$, is the statistical integrated strength result of the preferred factors, representing the possibility of the occurrence of hydrothermal resources. The thermal potential of the undiscovered hydrothermal $\dot{Q}^{\prime}$ in one region is a times of that of the identified hydrothermal resources $\dot{Q}$ in the same region. Such indicator favorability theory has also been used to estimate undiscovered resources in other industries such as mineral (Pan, 1993) and petroleum industry(Gao, et al., 2000).

$$
\dot{Q}^{\prime}=\alpha \times \dot{Q}
$$


In the latest USGS geothermal assessment, Williams, et al. investigated 5 evidence layers of heat flow, quaternary magmatism, quaternary faulting, seismicity, and tectonic stress (Williams, et al., 2009) to estimate the favorability factors of undiscovered hydrothermal resources in each state, as shown in Figure 2.4. The favorability factor for each state in this study was calculated to be the area average favorability factor, as shown in Equation 2.6, where $i$ indicates each of the region with its unique favorability factor in the target state, and $A$ is the region area.

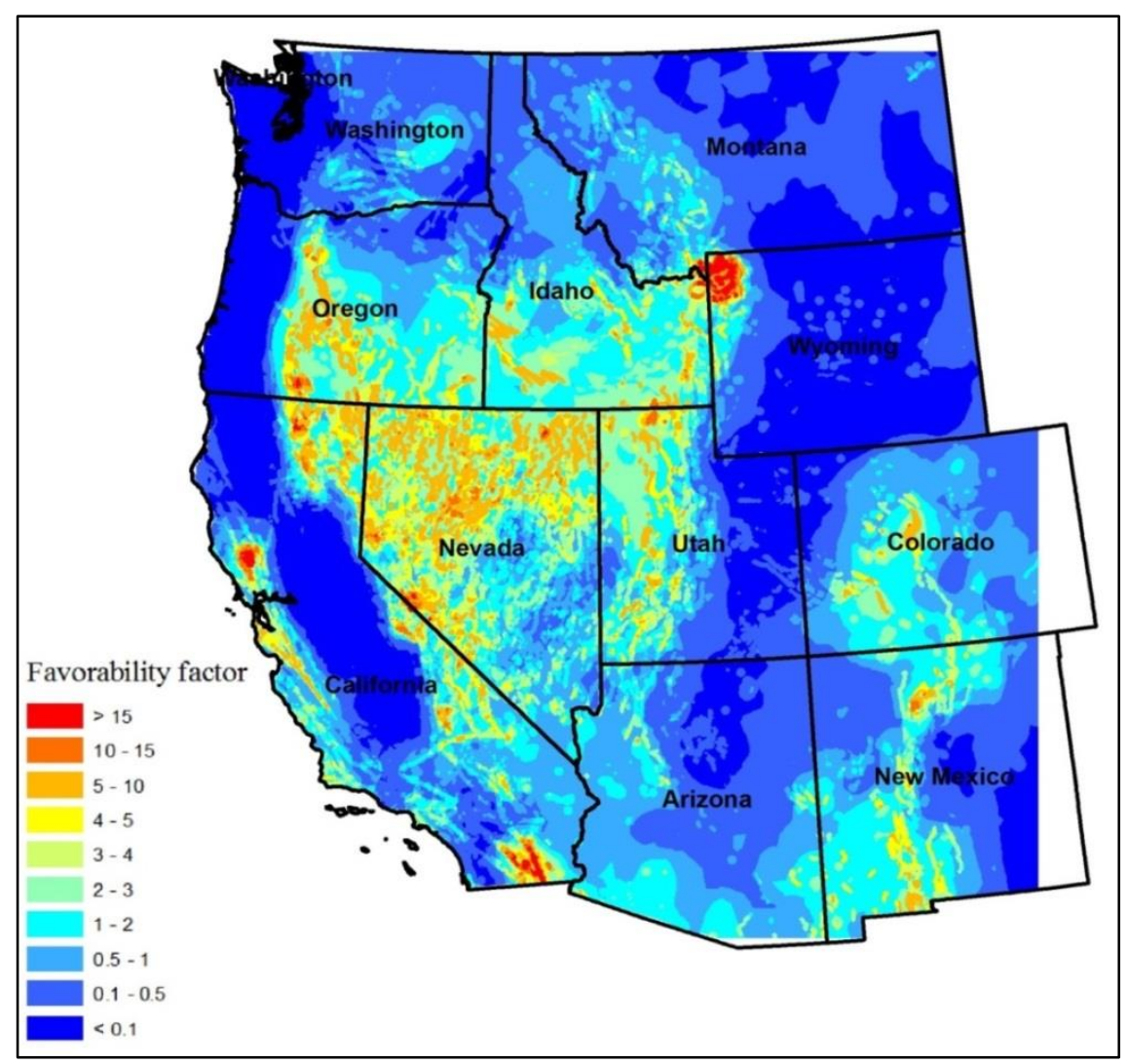

Figure 2.4: The favorability factor map of undiscovered hydrothermal resources in the western U.S. A warmer color indicates a higher probability to find the hydrothermal resources (Williams, et al., 2009).

$$
\alpha=\frac{\sum\left(\alpha_{i} \times A_{i}\right)}{\sum A}
$$


This study assumed the same reservoirs' characteristics of all the undiscovered resources in the same state. And the reservoirs' characteristics (depth, temperature, and flow rate) were assumed more similar to those of the larger identified resources with larger thermal potential than the smaller ones. The reservoirs' characteristics (depth, temperature, and flow rate) were estimated by calculating the mean-potential-weighted average of each of these parameters from the identified hydrothermal sites in each state, as shown in Equation 2.7 to 2.10 .

$$
\begin{aligned}
\beta_{i} & =\dot{Q}_{i} / \sum \dot{Q}_{i} \\
d_{R}{ }^{\prime} & =\sum\left(d_{R i} \times \beta_{i}\right) \\
T_{R}^{\prime} & =\sum\left(T_{R i} \times \beta_{i}\right) \\
\dot{m}_{R}{ }^{\prime} & =\sum\left(\dot{m}_{R i} \times \beta_{i}\right)
\end{aligned}
$$

Where $d_{R}{ }^{\prime}, T_{R}{ }^{\prime}, \dot{m}_{R}{ }^{\prime}$ is the depth, temperature, and flow rate of the undiscovered resources, $\beta_{i}$ is the potential weighted factor, $d_{R i}, T_{R i}, \dot{m}_{R i}, \dot{Q}_{i}$ is the depth, temperature, flow rate, and thermal potential of the identified resources in the same state.

\subsubsection{Near Hydrothermal EGS Resources}

Reservoir temperature and mass flow rate are the most important factors when determining the economics of a geothermal resource. The near hydrothermal EGS is defined as the geothermal resource around the hydrothermal site but lack sufficient permeability to let water through. Comparing to the deep EGS, the near hydrothermal EGS has a higher reservoir temperature at a shallower depth. So it is one kind of the least expensive EGS resource, and should be exploited first. Recently the U.S. Department of Energy and Ormat Technologies, Inc. announced the first EGS power plant connected to the commercial electricity grid, which is operating based on a near hydrothermal EGS resource, and is producing $1.7 \mathrm{MW}_{\mathrm{e}}$ of electricity.

There has not been a formal assessment of near hydrothermal EGS resources until now. Estimation of their thermal potential is preliminary and based on assumptions. Based on the definition of the resource, the reservoir temperature of the near hydrothermal EGS is 
the same as that of the hydrothermal resource being surrounded. Since thermal potential is only determined by the reservoir temperature and the mass flow rate, as shown in Equation 2.4, with temperatures being the same, the mass flow rate is the only one to distinguish the near hydrothermal EGS from the hydrothermal resources. Thus, it was assumed in this study that thermal potential of each near hydrothermal EGS $\dot{Q}_{n e a r}$ is the thermal potential difference between the mean and the high-end estimation of its corresponding hydrothermal resources, as shown in Equation 2.11:

$$
\dot{Q}_{n e a r}=\dot{Q}(95 \text { percentile })-\overline{\dot{Q}}
$$

As for estimation of the reservoir mass flow rate, Darcy's Law describes the flow rate through a porous medium is related to the permeability, the viscosity, the pressure gradient, and the drainage cross section. Although water viscosity can be determined easily in this case, the remaining parameters are dependents on the specific reservoir and of the hydraulic fracturing process technic. Therefore, estimation of the flow rate of an EGS is very site specific. Exploration drilling and in-situ well logging must be conducted. Without the exploration data, McVeigh assumed the mass flow rate as $54 \mathrm{~kg} / \mathrm{s}$ based on the current hydraulic fracture technology (McVeigh, et al., 2007). Augustine assumed the flow rate as $30 \mathrm{~kg} / \mathrm{s}$ and $60 \mathrm{~kg} / \mathrm{s}$ for the current and improved technology scenario (Augustine, et al., 2010). In this study, for near hydrothermal EGS the mass flow rate was assumed to be $40 \mathrm{~kg} / \mathrm{s}, 60 \mathrm{~kg} / \mathrm{s}$, and $80 \mathrm{~kg} / \mathrm{s}$. Calculations related to near hydrothermal EGS have considered these three different levels of production rates to provide a comprehensive view of such resources. For calculations based on other flow rates, one can interpret the results by assuming a linear relation in the 40 to $60 \mathrm{~kg} / \mathrm{s}$ or 60 to $80 \mathrm{~kg} / \mathrm{s}$ region.

\subsubsection{Deep EGS Resources}

Conventional hydrothermal resources usually exist at depth $3 \mathrm{~km}$ or less. The near hydrothermal EGS can be considered as the extensions of the hydrothermal resources, and also exist at a shallower depth. Deep EGS resources are the geothermal resources deeper than $3 \mathrm{~km}$, with dry and impermeable rocks. Artificial permeability increasing 
technologies like hydraulic fracturing are needed to reach the economic production rate. Because of the nature of the EGS resources, their thermal potential is enormous (Mock, et al., 1997). The latest systematic assessment of the U.S. EGS resources is the MIT report (Tester, et al., 2006). It used a series of temperature-at-depth maps developed by the SMU Geothermal Lab, from $3.5 \mathrm{~km}$ to $10 \mathrm{~km}$, to estimate the EGS potential with the above mentioned Volume Method. Figure 2.5 shows one of the temperature maps of the continental U.S. at depth $4.5 \mathrm{~km}$. The MIT report estimated $13,267,370 \times 10^{18}$ Joules of potential from deep EGS, which is approximately 132,673 times of the U.S. annual energy consumption, with extremely high levelized cost. Therefore, another trial to estimate potential of the EGS is not recommended. Instead, this study conducted a techno-economic case study of the EGS based GDHC system at WVU campus. Details are discussed in Chapter 3.

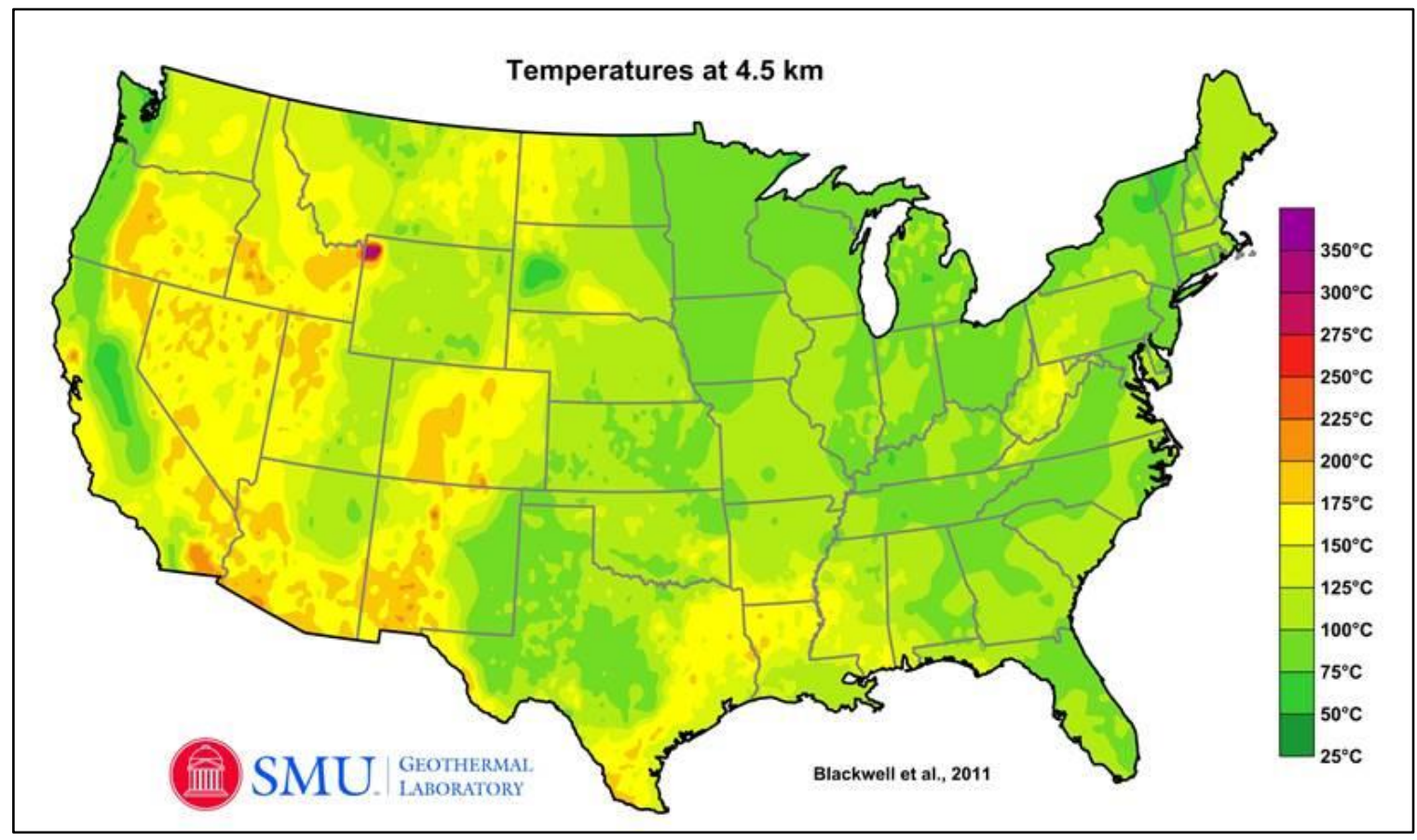

Figure 2.5: Map of underground temperature at $4.5 \mathrm{~km}$ of the continental U.S (Tester, et al., 2006). 


\subsection{Energy Market Characterization}

The demand and supply is the most fundamental basics of modern market. A careful market research is very essential for the success of any product, including renewable energy. Figure 2.6 shows the sharp decrease of annual U.S. crude oil imports corresponding to the rapid increase in renewable energy consumption. Based on the preliminary research, market demand impact on the economics of a GDHC project is much stronger than that on the economics of a geothermal power generation project. It is because the GDHC system is very location seneitive: geothermal heating and cooling must be consumed at the same location where it is produced, or the severe energy loss during the long hot water distribution will very much corrode the advantage of the low energy cost. However, the geothermal power plant can operate at a remote area, while the electricity is still able to be transferred thousands of miles away efficiently. This is why the previous geothermal power supply analysis is "not constrained by the potential market" (Petty, et al., 1992). But in this study, the size of the energy market is a crucial factor. Since the supply analysis is based on a site-by-site thermal potential and cost estimation, the energy market demand was also estimated site-by-site.

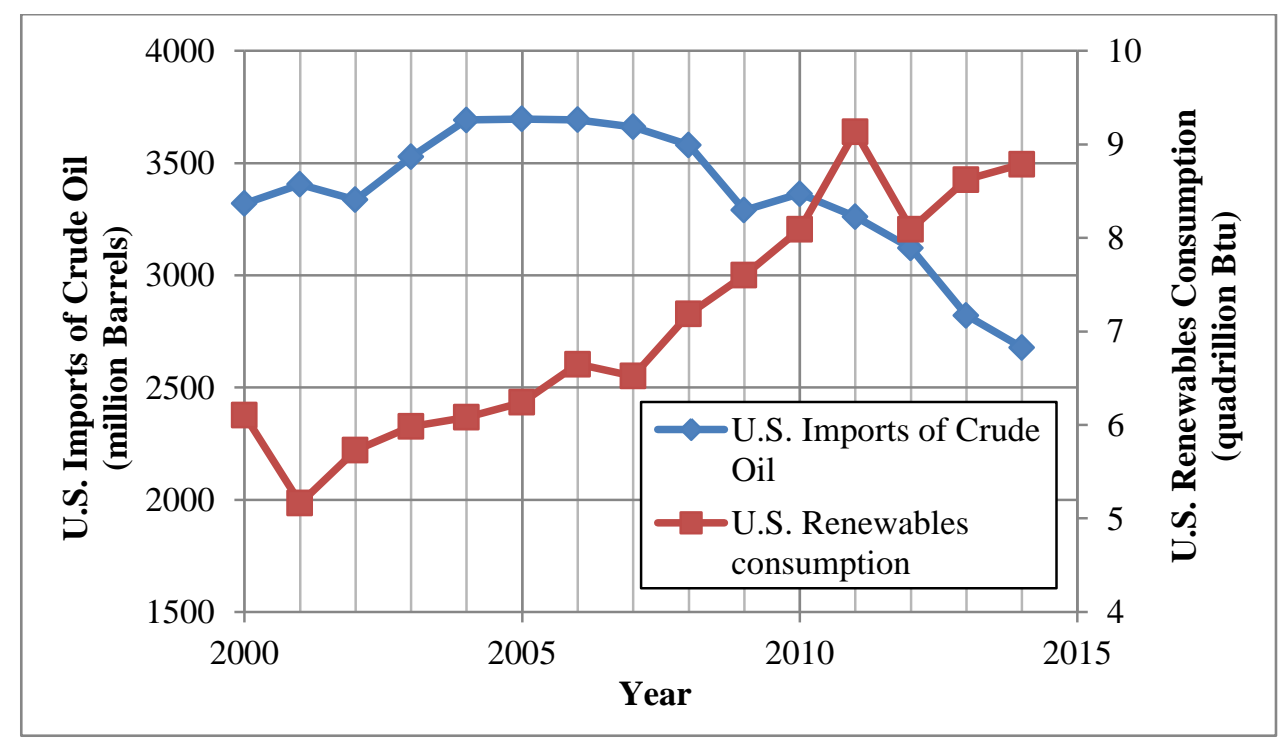

Figure 2.6: Comparison of annual U.S. crude oil imports and renewable energy consumption from 2000 to 2014, based on data from U.S. EIA. 


\subsubsection{Barriers to the GDHC Development}

Bloomquist and Lund identified some barriers to the development of geothermal district heating system from a survey based on 271 communities, among which only one community responded with interests (Bloomquist and Lund, 2000). For example, local authorities' unawareness of the geothermal energy benefits and local leaders' lack of the necessary knowledge to develop the system have shown to be detrimental to the expansion of geothermal energy. Thorsteinsson further studied 21 operating geothermal district heating systems and concluded the barriers into three categories: technical feasibility - most of the high quality hydrothermal resources have been developed into large scale power generation systems, while the technology to extract the huge EGS resources is immature; economic feasibility - the low cost of alternative energy forms such as natural gas and oil; social/political feasibility - the public and the leaders have inadequate knowledge of geothermal energy, and the geothermal research is severely underfunded (Thorsteinsson, 2008).

People tend to accept new things gradually. For example, the world's largest geothermal system - Reykjavik geothermal district heating system in Iceland, took nearly a century to develop from serving one house at the beginning to providing $61 \%$ of the total population of Iceland with hot water (Gunnlaugsson, 2008). One important assumption in this study was that, unlike the above situation, people would completely adopt geothermal energy as their primary heating and cooling source as soon as the GDHC system is built. No simulations were included to describe people's attitude of unfamiliar with geothermal energy to liking geothermal energy. Studying such expanding process of a renewable energy system is beyond the scope of this project. A good suggestion for future work is to add another system metric to represent the portion of people willing to use geothermal energy in the target area. A good example is explained in Labay and Kinnear's research to explore cunstomers' decision process in the adoption of solar energy (Labay and Kinnear, 1981). But in this study, it was simply assumed that the capacity of a GDHC system should meet the overall heating and cooling demands of the whole population. 


\subsubsection{Energy Demand Estimation}

This study aims to cover both the residential and the commercial buildings' heating and cooling demands. Since the energy consumption very much depends on the climate and the day-to-day ambient temperature, this study focuses to find the maximum heating and cooling demand, so that it can be used as the design capacity of the surface energy conversion facilities. Figure 2.7 shows the flow diagram of the energy demand estimation process.

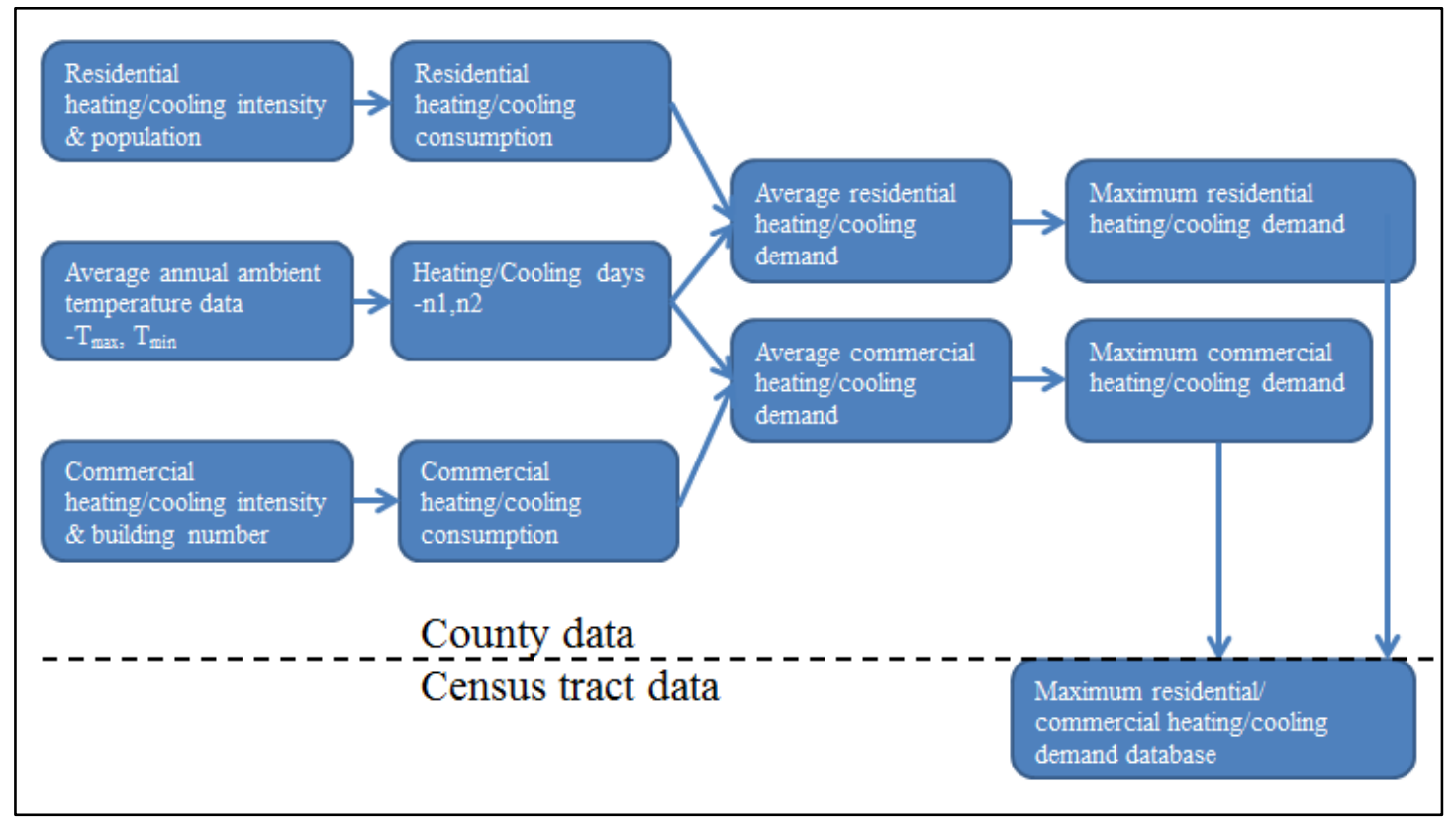

Figure 2.7: Flow diagram to estimate the energy demand of the target location.

This study estimated the overall energy demand with the overall population and the energy consumption intensity per capita for residential section, and with the overall building number and the energy consumption intensity per building for commercial section. The county and census tract based population data was found from the Topologically Integrated Geographic Encoding and Referencing database (TIGER) from U.S. Census Bureau. The commercial building number was found from the latest Commercial Buildings Energy Consumption Survey (CBECS) by U.S. EIA in 2003. The U.S. EIA estimates the consumptions of residential household's end-uses by the climate regions. Their heating and cooling intensities for different regions are shown in Table 2.2. 
The CBECS estimates the consumptions of commercial building's end-uses by the census regions. Their heating and cooling intensities are shown in Table 2.3.

Table 2.2: Residential buildings heating/cooling consumptions (MMBtu/household) by U.S. climate regions in 2009.

\begin{tabular}{|c|c|c|c|}
\hline Climate Region & Space Heating, $\delta_{S H}$ & Water Heating, $\delta_{W H}$ & Cooling, $\delta_{C}$ \\
\hline Very Cold/Cold & 60.5 & 18.3 & 2.0 \\
\hline Mixed-Humid & 37.8 & 16.2 & 6.5 \\
\hline Mixed-Dry/Hot-Dry & 18.2 & 15.3 & 8.7 \\
\hline Hot-Humid & 11.9 & 11.7 & 14.5 \\
\hline Marine & 26.4 & 14.5 & 1.2 \\
\hline & \\
U.S. Climate & \\
Region Map & & \\
& \\
\end{tabular}

Table 2.3: Commercial buildings heating/cooling consumption (trillion Btu) of the mountain and the pacific region, in western U.S., 2003.

\begin{tabular}{|c|c|c|c|}
\hline Census Region & Space Heating, $\Delta_{S H}$ & Water Heating, $\Delta_{W H}$ & Cooling, $\Delta_{C}$ \\
\hline Mountain & 167 & 41 & 31 \\
\hline Pacific & 131 & 68 & 55 \\
\hline
\end{tabular}

This study assumed a trigonometric function to curve-fit the year-round ambient temperature. The function of the day-to-day ambient temperature $T_{a b}$ is shown in Equation 2.12:

$$
T_{a b}=\left(T_{a b M a x}-T_{a b M i n}\right) \times \sin \left(\frac{\pi}{365 n}\right)+T_{a b M i n}
$$


The maximum and minimum ambient temperatures for each location were found from the National Climatic Data Center database. It was also assumed that days with temperature lower than $18.3^{\circ} \mathrm{C}$ accounted into space heating days, while days with temperature greater than $18.3^{\circ} \mathrm{C}$ accounted into cooling days. The total heating days $n_{H}$ and cooling days $n_{C}$ can be calculated by Equation 2.13:

$$
\left\{\begin{array}{c}
n_{H}=365 \times \frac{18.3-T_{a b M i n}}{T_{a b M a x}-T_{a b M i n}} \\
n_{C}=365-n_{H}
\end{array}\right.
$$

Thus, taking the residential part as an example, the peak heating and cooling demands were calculated by Equation 2.14 and 2.15, where $h h$ is the household number and $p p l$ is the population. The commercial part was estimated with the similar process.

$$
\begin{aligned}
& \text { Heating: }\left\{\begin{array}{c}
T_{a b M a x}>18.3, \dot{H}_{\text {peak }}=\left(\frac{\delta_{S H} \times h h}{n_{H}}+\frac{\delta_{W H} \times h h}{365}\right) \times \frac{p p l_{\text {Census }}}{p p l_{\text {County }}} \times \frac{\pi / 365^{\times n_{H}}}{\sin \left(\pi / 365 \times n_{H}\right)} \\
T_{a b M a x}<18.3, \dot{H}_{\text {peak }}=\left(\frac{\delta_{S H} \times h h}{n_{H}}+\frac{\delta_{W H} \times h h}{365}\right) \times \frac{p p l_{\text {Census }} \times \pi}{p p l_{\text {County }}}
\end{array}\right. \\
& \text { Cooling: }\left\{\begin{array}{c}
T_{a b M a x}>18.3, \dot{C}_{\text {peak }}=\left(\frac{\delta_{C} \times h h}{n_{C}}\right) \times \frac{p p l_{\text {Census }}}{p p l_{\text {County }}} \times \frac{\pi / 365 \times\left(n_{C}-n_{H}\right)}{\cos \left(\pi / 365 \times n_{H}\right)-\cos \left(\pi / 365^{\times} n_{C}\right)} \\
T_{a b M a x}<18.3, \dot{C}_{\text {peak }}=0
\end{array}\right.
\end{aligned}
$$

\subsection{LCOH Model Development}

As mentioned in section 2.3, none of the existing cost models can be perfectly implemented into this study considering the GDHC system's feature of energy production and consumption balance. This part of the study discusses how to develop the cost model for GDHC system and calculates the LCOH. Six categories of parameters have been used to characterize the system. They are:

1) Resource parameters - Geothermal temperature, geothermal gradient, etc. 
2) Market parameters - Population density, energy intensive, climate data, etc.

3) Capital parameters - Well drilling and exploration, stimulation cost, heating and cooling unit cost, etc.

4) O\&M parameters - Reservoir O\&M, surface facility O\&M, make-up wells.

5) Financial parameters - Discount rate, lifetime, capacity factor, etc.

6) Risk parameters - Possible ranges for the above selected parameters.

With these parameters, the cost model first accesses the reservoir database to get the essential reservoir characteristics, and then calculates target heating/cooling demand; based on local energy demand, the cost model defines the wells' production rate and designs the corresponding surface heating and cooling unit, as well as the distribution system. Finally, it calculates the levelized cost of energy and annual energy production as well as a series of economic parameters such as capital cost, $\mathrm{O} \& \mathrm{M}$ cost, project cash flow details, etc. The following part discusses two modules which constitute the cost model, namely - surface facility design and economics, and well design and economics. They were developed in Excel spreadsheets, with necessary reservoir database and economic factor database. The cost model was designed to function as a standalone or be called in as an Excel-customized macro by other programs.

\subsubsection{Surface Facility Design and Economics}

Surface equipment for a GDHC system mainly consists of a distribution network, a series of heat exchangers for heating, and an absorption chiller system for cooling. This part of the study illustrates the surface equipment layout, the necessary design and their cost evaluation.

The GDHC system aims to provide heating and cooling to a large number of people. The assumption that every person at the target area would accept the geothermal energy at the beginning eliminates concerns about gradual expansion of the distribution network. Since geothermal reservoirs exist in different locations with different population densities, a general living pattern was assumed and imposed on the design of the distribution network. As shown in Figures 2.8a, 2.8c, and 2.8d, it was assumed that houses are spaced geographical-uniformly throughout the whole area. A uniform distance between two 
buildings was assumed as $D_{N N}$, which decreases with increase in population and number of houses. When the population reaches a point such that $D_{N N}$ reaches a required minimum, people tend to live in apartment buildings rather than building more houses. The described housing pattern is repeated by more number of apartment buildings with larger building stories until the population reaches saturation. It is to be noted that at low population density, people tend to live closely as shown in Figure $2.8 \mathrm{~b}$, rather than the assumed scenario illustrated in Figure 2.8a. However, the use of a GDHC system in a low population density area may not be economically feasible since its cost per capita is expected to be much higher. Developing GDHC for such a scenario is not the interest of this study.

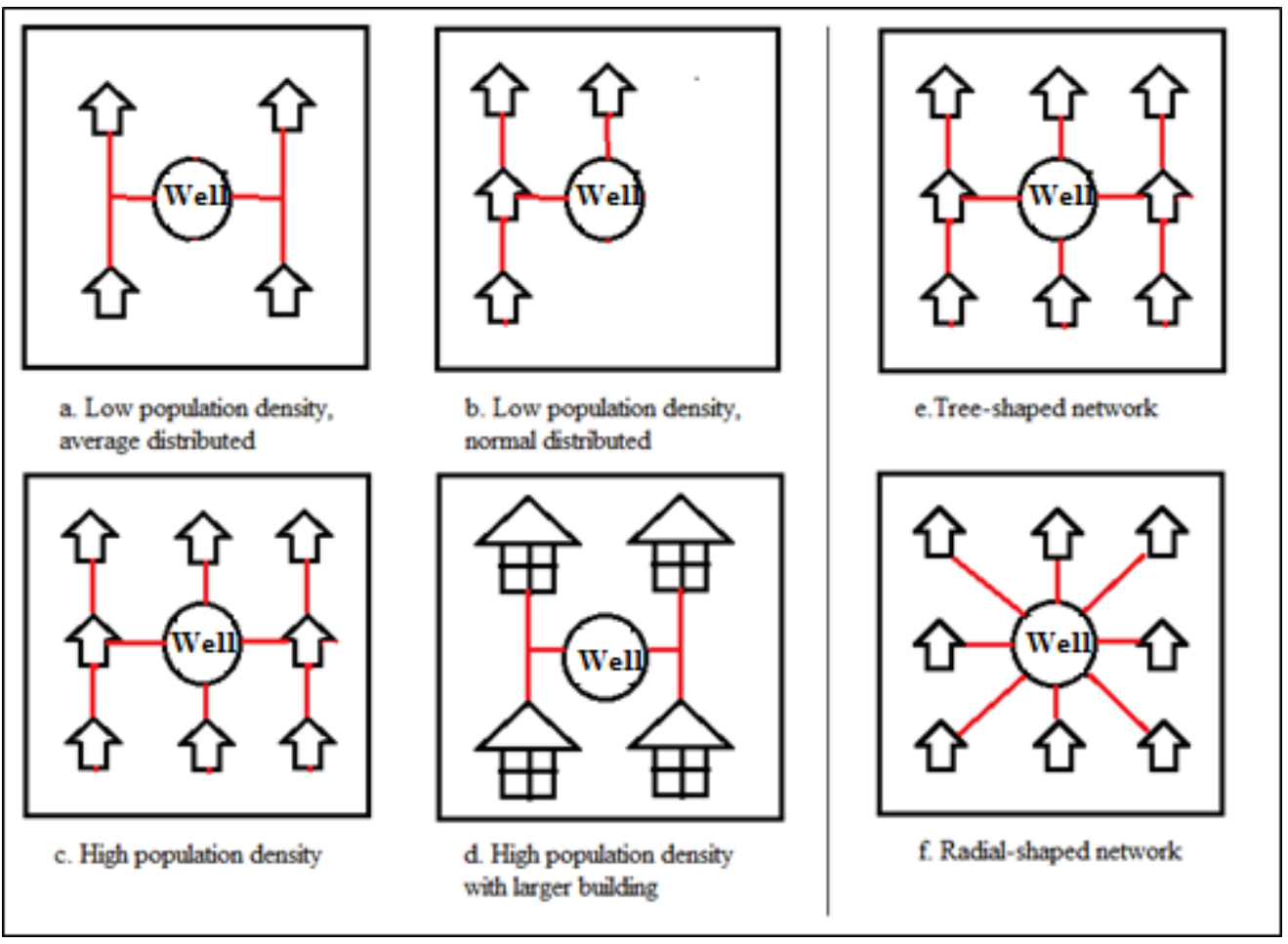

Figure 2.8: The housing pattern with increase population and distribution network design.

The geothermal production wells were assumed to be located at the center of the target area. Based on the Xia's research on Hong Kong's cooling distribution network (Xia, et al., 2011), a tree-shaped design shown in Figure 2.8e, is more economical than a radialshaped design shown in Figure 2.8f, when the service nodes are greater than ten. Furthermore, the length of the pipeline $L$ is a function of the service nodes number $N$ and 
the average distance between two nodes $D_{N N}$, as shown in Equation 2.16. Based on Ogden's research on the hydrogen transition strategies, the average distance between two nodes $D_{N N}$, is a function of the target area $A$ and nodes number $N$, as shown in Equation 2.17 .

$$
\begin{aligned}
& L=D_{N N} \times N^{1.04} \\
& D_{N N}=\sqrt{0.15 \times A / N}
\end{aligned}
$$

As a result, the length of the distribution line was calculated in Equation 2.18,

$$
L=\left\{\begin{array}{c}
p p l<1500, L=0.4 \times A^{0.5} \times(p p l / 3)^{0.54} \\
1500<p p l<5000, L=0.4 \times A^{0.5} \times(p p l / 6)^{0.54} \\
p p l>5000, L=0.4 \times A^{0.5} \times(p p l / 8)^{0.54}
\end{array}\right.
$$

The capital cost of the pipeline $C A P_{\text {pipe }}$ was calculated in Equation 2.19 to 2.21, based on Persson and Werner's research on hot water distribution cost based on European cities (Persson and Werner, 2011).

$$
\begin{aligned}
& C A P_{\text {pipe }}=L \times c_{0} \\
& c_{0}=c_{1}+D \times c_{2} \\
& D=0.0486 \times \ln \left(G_{S} / L\right)+0.0007
\end{aligned}
$$

Where $c_{0}, c_{1}$, and $c_{2}$ are cost constants for the pipeline, as shown in Table 2.4, D is the pipeline diameter, and $G_{s}$ is the annual energy provided through the pipeline.

Table 2.4: Cost constants for pipeline capital cost calculation.

\begin{tabular}{|c|c|c|}
\hline & $c_{1} \$ / \mathrm{m}$ & $c_{2,} \$ / \mathrm{m}^{2}$ \\
\hline Outer area, population $<1500$ & 198.716 & 1818.448 \\
\hline Median, 1500<population $<5000$ & 281.624 & 2270.1 \\
\hline Inner city, population $>5000$ & 376.316 & 2660.952 \\
\hline
\end{tabular}


Equation 2.22 to 2.26 were used to estimate the pumping cost $P C$, where $\Delta P_{f}$ is the pressure drop due to the friction, $f$ is the friction coefficient, $\rho$ is water density, $v$ is the water flow velocity, $R e$ is the Reynolds number, $e$ is electricity rate, $\dot{V}$ is the volume flow rate, $m_{p}$ is the mass flow rate, $\eta_{\text {pump }}$ is the pump efficiency, and $t$ is the pumping time. The friction coefficient $f$ was calculated by Equation 2.23 for turbulent flow $\left(10^{4}>R e>\right.$ $4 \times 10^{8}$ ), where $\varepsilon$ is the average roughness for steel pipes, and was assumed to be 0.045 mm (Chen, 1979).

$$
\begin{gathered}
-\Delta P_{f}=\frac{2 \times f \times \rho \times v^{2} \times L}{D} \\
\frac{1}{\sqrt{4 f}}=-2 \times \log \left\{\frac{\varepsilon}{3.7065 D}-\frac{5.0452}{\operatorname{Re}} \log \left[\frac{1}{2.8257}\left(\frac{\varepsilon}{D}\right)^{1.1098}+\frac{5.8506}{\operatorname{Re}^{0.8981}}\right]\right\} \\
v=\frac{\dot{V}}{\pi D^{2} / 4} \\
\dot{V}=\dot{m}_{p} / \rho \\
P C_{\text {surface }}=\frac{e}{\eta_{\text {pump }}} \times\left(\Delta P_{f}\right) \times \dot{V} \times t
\end{gathered}
$$

A basic building heating unit is shown in Figure 2.9, with a shell and tube heat exchanger outside the building (OUT-HXER), and a hot water radiator inside the building (RADIATOR). The geothermal hot water is sent to each building and go through the shell side of the heat exchanger. Another loop of water is circulating through the tube side of the heat exchanger and the radiator. The use of the secondary loop of water inside the building helps to prevent hot corrosive geothermal water from scaling the indoor pipes which are usually installed inside the walls and are hard to replace. 


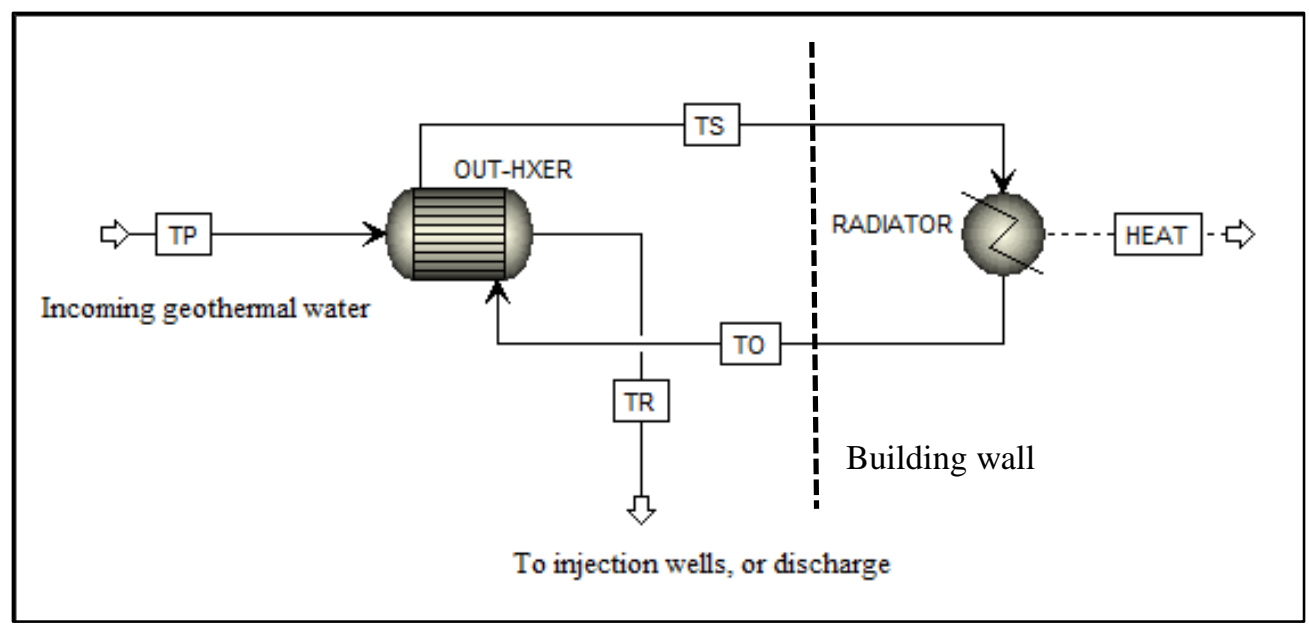

Figure 2.9: Schematic of the building heating unit of a GDHC system.

The theory of heat exchanger design has been well developed, e.g. (Fraas, 1989), and (Shah and Sekulic, 2003). The size of the OUT-HXER was determined by a set of user defined parameters at reference state, which are shown in Table 2.5.

Table 2.5: Streams table of the building heating unit.

\begin{tabular}{|c|c|c|c|}
\hline Stream & From & To & $\begin{array}{c}\text { Value at } \\
\text { reference state }\end{array}$ \\
\hline$T_{p}$ & $\begin{array}{c}\text { Production } \\
\text { well }\end{array}$ & OUT-HXER & $\begin{array}{c}85^{\circ} \mathrm{C} \text { to } 210^{\circ} \mathrm{C}, \\
\text { from reservoir } \\
\text { database }\end{array}$ \\
\hline$T_{r}$ & OUT-HXER & $\begin{array}{c}\text { Reinjection } \\
\text { well }\end{array}$ & $43^{\circ} \mathrm{C}$ \\
\hline$T_{s}$ & OUT-HXER & RADIATOR & $80^{\circ} \mathrm{C}$ \\
\hline$T_{o}$ & RADIATOR & OUT-HXER & $40^{\circ} \mathrm{C}$ \\
\hline$H E A T$ & RADIATOR & $\begin{array}{c}\text { Inside } \\
\text { building }\end{array}$ & $\begin{array}{c}\text { Peak heating } \\
\text { demand }\end{array}$ \\
\hline
\end{tabular}

The size of the OUT-HXER was calculated by Equation 2.27 and 2.28, where $A_{H X}$ is the heat transfer area, $\dot{H}_{0}$ is the estimated peak heating demand, $U$ is the heat transfer coefficient, $F$ is the correction factor, and subscript 0 indicates the reference state. The 
OUT-HXER was assumed to be a single shell pass, two tube passes heat exchanger, and the correction factor $F$ was found from Bowman, et al.'s chart for a 1-2 heat exchanger (Bowman, et al., 1940).

$$
\begin{aligned}
& A_{H X}=\dot{H}_{0} /\left(U \times F \times L M T D_{\text {out } 0}\right) \\
& L M T D_{\text {out } 0}=\frac{\left(T_{p 0}-T_{s 0}\right)-\left(T_{r 0}-T_{o 0}\right)}{\ln \left(\left(T_{p 0}-T_{s 0}\right) /\left(T_{r 0}-T_{o 0}\right)\right)}
\end{aligned}
$$

For the hot water radiator inside the building, the film coefficients of the streams inside and outside of the tubes were assumed to be constant. Therefore, the overall heat transfer coefficient was also assumed to be constant. Then the Valdimarsson's equation was used to calculate the normal operating states based on the reference state of the hot water radiator, as shown in Equation 2.29 (Valdimarsson, 1993).

$$
\left(\frac{\dot{H}}{\dot{H}_{0}}\right)^{1.3}=\frac{L M T D_{\text {in }}}{L M T D_{\text {in } 0}}=\frac{\left[\left(T_{s}-T_{\text {room }}\right)-\left(T_{o}-T_{\text {room }}\right)\right] / \ln \left[\left(T_{s}-T_{\text {room }}\right) /\left(T_{o}-T_{\text {room }}\right)\right]}{\left[\left(T_{s 0}-T_{\text {room }}\right)-\left(T_{o 0}-T_{\text {room }}\right)\right] / \ln \left[\left(T_{s 0}-T_{\text {room }}\right) /\left(T_{o 0}-T_{\text {room }}\right)\right]}
$$

The temperature drop of the water inside the radiator was assumed to be $40^{\circ} \mathrm{C}$, and the heating demand was assumed to follow the sine function throughout the whole year with the peak demand occurs at minimum ambient temperature, as shown in Equation 2.30 and Equation 2.31:

$$
\begin{aligned}
& T_{s}-T_{o}=40 \\
& \dot{H}=\dot{H}_{0} \times \cos \left(\frac{\pi}{365} \times n\right)
\end{aligned}
$$

The $T_{s}$ and $T_{o}$ was then solved on a daily basis. The mass flow rate of the geothermal production water was calculated by Equation 2.32, where $T_{r}=T_{o}+3$.

$$
\dot{m}_{p}=\dot{H} /\left[C_{\text {water }} \times\left(T_{p}-T_{r}\right)\right]
$$


The capital cost of the heat exchanger $C A P_{H X}$ was calculated by Equation 2.33 (Stevenson, 2014), where $c_{3}$ is the cost constant for heat exchangers.

$$
C A P_{H X}=c_{3} \times \exp \left[8.821-0.30863 \times\left(\ln A_{H X}\right)+0.0681 \times\left(\ln A_{H X}\right)^{2}\right]
$$

A centralized single-effect water/lithium bromide absorption chiller was assumed in this study, as illustrated in Figure 2.10. Design of the absorption chiller system consulted Somers' work (Somers, et al., 2011). Table 2.6 shows the stream table of the absorption chiller system. The distribution network is switched to deliver chilled water to each building in summer. The absorption chiller system mainly has three phases, which are the evaporation, absorption, and regeneration. The low pressure water (stream 9) goes through the evaporator, evaporates into the steam, and extracts energy from the surrounding environments, which provides cooling. The use of the valves and the pump is to decrease the evaporator feeding's pressure in order to stimulate the evaporation process. The pure steam (stream 10) is then absorbed by the concentrated LiBr solution at the absorber. The use of $\mathrm{LiBr}$ solution can significantly increase its capability of absorbing steam. Then the $\mathrm{LiBr}$ solution (stream 1) is heated up by a series of heat exchangers so that water can be flashed back into steam (stream 6) for the next loop of the evaporation process. The geothermal hot water is used in one of the heat exchangers (HX-GEO). So the incoming temperature of stream GEOIN was equal to the geothermal production temperature, while the return temperature of stream GEOOT was calculated by assuming a pinch temperature of the heat exchanger $\mathrm{HX}-\mathrm{GEO}$ to be $5^{\circ} \mathrm{C}$. Table 2.6 shows the streams properties for providing a $6.3 \mathrm{MW}_{\text {th }}$ cooling demand. For other cooling demands, this model is simulated to determine the flow rates of the streams, while the temperatures and pressures are the same. Therefore, mass flow of the geothermal production water at heat exchanger HX-GEO was calculated by Equation 2.34, where $\dot{Q}_{H X}$ is the net duty of HX-GEO calculated by the Aspen Plus model.

$$
\dot{m}_{p}=\dot{Q}_{H X} /\left[C_{\text {water }} \times\left(T_{p}-T_{r}\right)\right]
$$


Table 2. 6: Streams table of the absorption chiller system.

\begin{tabular}{|c|c|c|c|c|c|c|}
\hline Stream & 1 & 2 & 3 & 4 & 5 & 6 \\
\hline Temperature, ${ }^{\circ} \mathrm{C}$ & 32.70 & 32.69 & 64.80 & 65.76 & 90.00 & 89.90 \\
\hline Pressure, $\mathrm{kPa}$ & 0.67 & 7.46 & 7.46 & 7.46 & 7.46 & 7.46 \\
\hline Flow rate, $\mathrm{kg} / \mathrm{s}$ & 32.40 & 32.40 & 32.40 & 32.40 & 32.40 & 2.68 \\
\hline LiBr fracture, \% & 21.84 & 21.84 & 21.84 & 21.84 & 21.84 & 0 \\
\hline Vapor fracture, \% & 0.00 & 0.00 & 0.00 & 0.00 & 12.00 & 100.00 \\
\hline
\end{tabular}

Table 2.6 continued

\begin{tabular}{|c|c|c|c|c|c|c|c|}
\hline Stream & 7 & 8 & 9 & 10 & 11 & 12 & 13 \\
\hline Temperature, ${ }^{\circ} \mathrm{C}$ & 78.40 & 40.20 & 1.31 & 1.30 & 89.90 & 53.30 & 43.15 \\
\hline Pressure, $\mathrm{kPa}$ & 7.46 & 7.46 & 0.67 & 0.67 & 7.46 & 7.46 & 0.67 \\
\hline Flow rate, $\mathrm{kg} / \mathrm{s}$ & 2.68 & 2.68 & 2.68 & 2.68 & 29.72 & 29.72 & 29.72 \\
\hline LiBr fracture, \% & 0 & 0 & 0 & 0 & 25.75 & 25.75 & 25.75 \\
\hline Vapor fracture, \% & 100.00 & 0.00 & 9.30 & 100.00 & 0.00 & 0.00 & 1.10 \\
\hline
\end{tabular}




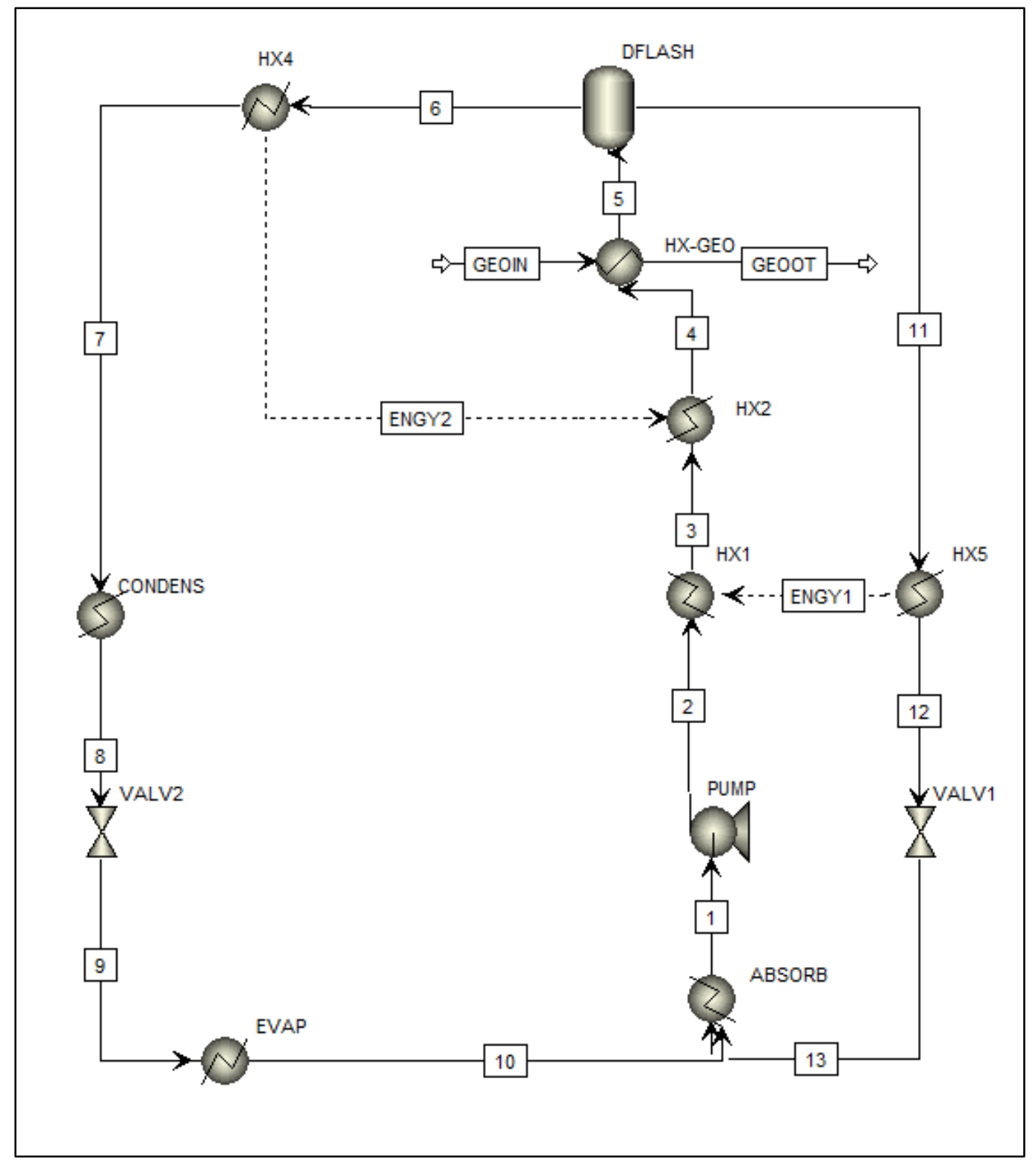

Figure 2.10: Schematic of the absorption chiller, cooling provided at EVAP, geothermal hot water flows through HX-GEO.

The capital cost of the absorption chiller $C A P_{A C}$ was calculated by Equation 2.35 to 2.37, where $C A P_{a b s}$ is the absorption tank cost, $C A P_{\text {pump }}$ is the centrifugal pump cost, $\dot{C}_{0}$ is the estimated peak cooling demand, $c_{4}$ and $c_{5}$ are cost constants for the absorption tank and the pump (Mahone, 1998).

$$
C A P_{A C}=C A P_{H X}+C A P_{a b s}+C A P_{\text {pump }}
$$




$$
\begin{aligned}
& C A P_{a b s}=c_{4} \times \dot{C}_{0} \\
& C A P_{\text {pump }}=c_{5} \times \dot{C}_{0}
\end{aligned}
$$

The annual operation and maintenance cost (O\&M) of the surface facilities was calculated by investigating the direct cost, such as the labor cost $c_{\text {labor }}$ and the fixed cost (tax and depreciation), as shown in Equation 2.38 (Turton, et al., 2008). $c_{\text {labor }}$ is found from the Bureau of Labor Statistics (BLS, 2013).

$$
O M_{\text {surface }}=2.065 \times c_{\text {labor }}+0.246 \times\left(C A P_{\text {pipe }}+C A P_{H X}+C A P_{A C}\right)
$$

\subsubsection{Well Design and Economics}

Geothermal drilling technology has been adapted from oil and gas practices, and has matured in the past 30 years since the development of the Geysers geothermal power plants in California. The maximum well production rate in this study was assumed to be $40 \mathrm{~kg} / \mathrm{s}$, and preliminary research has shown that for most of the target areas, three production wells are enough to provide sufficient energy for heating and cooling purposes. The injection-production wells arrangement was assumed to follow the oil field practice, with well spacing around 500 meters to ensure maximum energy extraction and minimum thermal drawdown for such a geothermal system with 30 years lifetime. With the exception of wells in EGS reservoirs, wells were assumed to be drilled to the depth from the USGS database identified in section 2.4 to reach the desired temperature and sufficient fracture for water flow. Subsequently, the number of production wells is calculated based on the required mass flow estimated in the surface design part in section 2.5. For deep EGS wells, the high cost of deep drilling will offset the advantage of the high temperature. The optimum among these scenarios must be discussed case by case, and is not included in this study.

Geo-fluid pumping is also needed, for injection wells to overcome the friction losses and for production wells to lift the production water to the surface. The setting depth of the pump $d_{\text {pump }}$ and its capacity $\dot{W}_{\text {pump }}$ were calculated by Equation 2.39 and 2.40, where $P_{R}$ is the reservoir pressure, $f_{R}$ is the overall friction. The cost of the pump was calculated by 
Equation 2.41. Calculations of annual pumping cost in the well field followed the same as described in section 2.5 .

$$
\begin{aligned}
& d_{\text {pump }}=d_{R}-\frac{P_{R}}{\rho \times\left(1+f_{R}\right)} \\
& \dot{W}_{\text {pump }}=40 \times d_{\text {pump }} / \eta_{\text {pump }} \\
& C A P_{\text {pump }}=c_{5} \times \dot{W}_{\text {pump }}
\end{aligned}
$$

There are not enough geothermal drilling data available to give an accurate estimation of the overall exploration to completion stages of geothermal wells. However, the oil and gas well drilling industry is well established with thousands of wells drilled every year. For this part of the study, collaborating with Cornell University geothermal group, the MIT Depth Dependent (MITDD) drilling index was updated with the latest available drilling data, and was used for the drilling cost estimation. The overall drilling expense and overall drilling depth database were updated to 2009 based on the Joint Association Survey on Drilling Costs 2009 (JAS) from the American Petroleum Institute. For an assumed drilling depth interval, the cost per meter data was calculated, then a unified polynomial function was used to fit all the data from all the drilling intervals, as shown in Equation 2.42. Figure 2.11 pictures the function between the drilling depth and the drilling cost.

$$
\begin{aligned}
C A P_{\text {drill }}= & 1.1592-1.908 \times 10^{-14} \times d_{R}{ }^{4}+4.0292 \times 10^{-10} \times d_{R}{ }^{3} \\
& -2.5874 \times 10^{-6} \times d_{R}{ }^{2}+8.5065 \times 10^{-3} \times d_{R}
\end{aligned}
$$




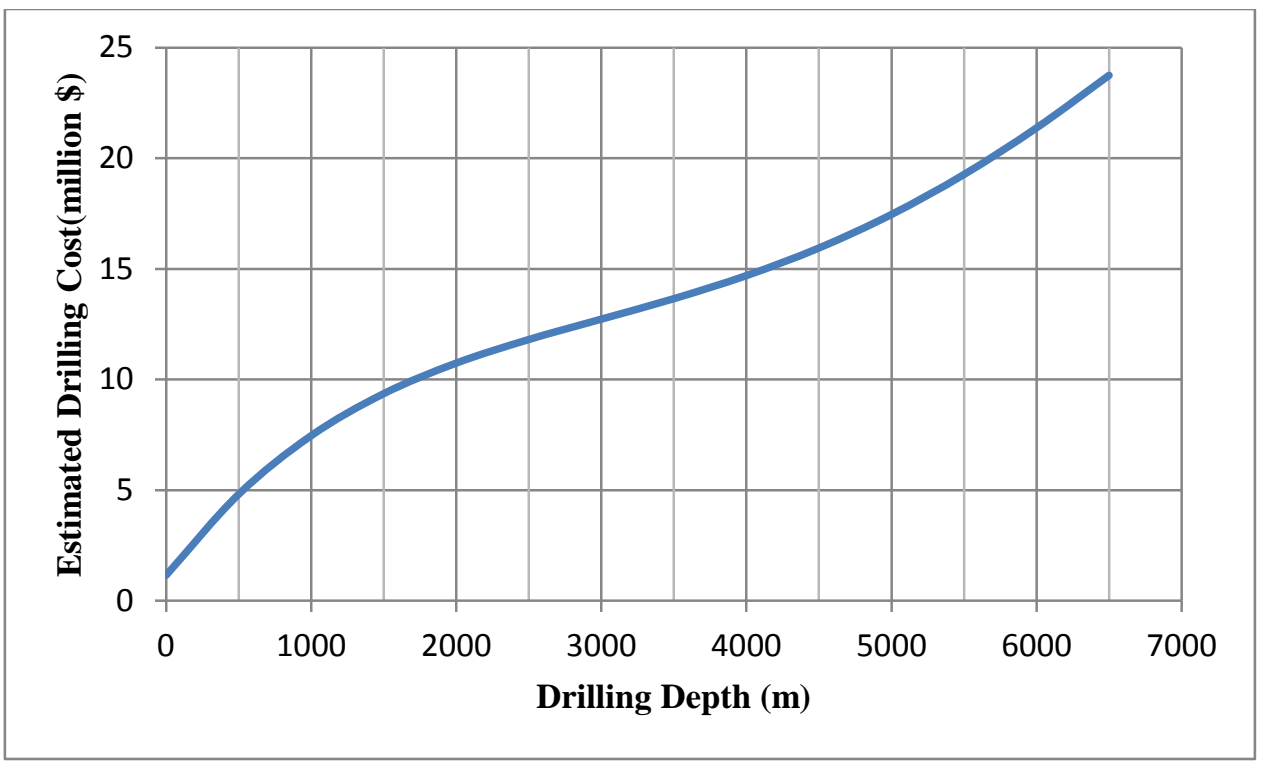

Figure 2.11: The drilling cost function with drilling depth.

The exploration wells are used by geologists to explore and confirm the existence of geothermal energy. The success of the exploration wells is essential to an economical drilling activity. Cost of exploration wells is usually less than that of production wells, but depends on the successful rate. The cost of exploration $C A P_{\text {expl }}$ was calculated by Equation 2.43, where $c_{6}$ is cost constant, and $\chi$ is the exploration successful rate.

$$
C A P_{\operatorname{expl}}=0.58 \times \exp \left(c_{6} \times d_{R}\right) \times \frac{1}{\chi}
$$

For near hydrothermal EGS reservoirs, well stimulation is needed to increase the porosity and permeability of the reservoir. The cost of stimulation $C A P_{\text {fracture }}$ is mainly the cost of huge amount of water used to fracture the reservoirs, and hence the pumping cost and water storage cost. Practices from the Marcellus shale industry suggest a cost range at $\$$ 1500 to $\$ 1800$ per meter of hydraulic fracturing. For a depth of 2500 meter reservoir, 0.8 million kilograms of water is needed to pump into the reservoir in 24 hours, creating a 69 MPa pressure to stimulate the rocks. The detailed cost is shown in Table 2.7, calculation based on cost per unit mass of water from Hefley and Seydor's research on Marcellus shale gas explorations (Hefley and Seydor, 2011). Estimations for the stimulation cost of the near hydrothermal EGS resources in this study followed the same process. 
Table 2.7: Stimulation cost breakdown for a 2,500-meter well based on practices from the Marcellus shale industry.

\begin{tabular}{|c|c|}
\hline Item & Cost, $\$$ \\
\hline Water & 648 \\
\hline Pump fuel & 8,000 \\
\hline Storage & 180,000 \\
\hline Pipeline & 475,200 \\
\hline Sand & 1,600 \\
\hline Total & 665,448 \\
\hline
\end{tabular}

The annual operation and maintenance cost $(\mathrm{O} \& \mathrm{M})$ of the well side was calculated as $25 \%$ of the labor cost $c_{\text {labor }}$ and $1 \%$ of the capital investment, as shown in Equation 2.44.

$$
O M_{\text {well }}=0.25 \times c_{\text {labor }}+0.01 \times\left(C A P_{\text {pump }}+C A P_{\text {drill }}+C A P_{\text {expl }}+C A P_{\text {fracture }}\right)
$$

\subsubsection{Risk Analysis}

In 2009, the US Department of Energy Geothermal Technology Program conducted a detailed risk analysis of the EGS technology (Young and Augustine, 2010). This part of the study consulted some of the probabilistic metrics which are also essential for the economics of the hydrothermal resources and near hydrothermal EGS from the risk analysis report. Moreover, the reservoir temperature profiles from the USGS database are also in a range of values with possibilities. With these probabilistic metrics, estimations of resources' thermal potential and their $\mathrm{LCOH}$ are expected in in a range of values with possibilities. Table 2.8 lists the probabilistic metrics which were used in this study. The Palisade decision tool @Risk was used to conduct Monte Carlo simulations for the risk analysis in this study. 
Table 2.8: Probabilistic metrics for risk analysis in the cost model, data follows a triangle distribution, in the format of (minimum value, most likely value, maximum value).

\begin{tabular}{|c|c|c|c|c|}
\hline Metrics & $\begin{array}{c}\text { Identified } \\
\text { hydrothermal } \\
\text { resources }\end{array}$ & $\begin{array}{c}\text { Undiscovered } \\
\text { hydrothermal } \\
\text { resources }\end{array}$ & $\begin{array}{c}\text { Near-hydro EGS } \\
\text { resources }\end{array}$ & Reference \\
\hline $\begin{array}{l}\text { Reservoir } \\
\text { temperature }\end{array}$ & \multicolumn{3}{|c|}{ Data directly or estimated from USGS database } & USGS \\
\hline $\begin{array}{l}\text { Exploration } \\
\text { success rate }\end{array}$ & $(0.2,0.35,0.5)$ & $(0.1,0.17,0.25)$ & $(0.2,0.35,0.5)$ & \multirow{4}{*}{$\begin{array}{c}\text { Young } \\
\text { and } \\
\text { Augustine, } \\
2010\end{array}$} \\
\hline $\begin{array}{l}\text { Non-well } \\
\text { exploration } \\
\text { cost, } \times 10^{6} \$\end{array}$ & \multicolumn{2}{|c|}{$(0.513,1.174,2.002)$} & $(0.417,1.314,2.534)$ & \\
\hline $\begin{array}{l}\text { Drilling cost } \\
\text { multiplier }\end{array}$ & \multicolumn{3}{|c|}{$(0.59,0.86,1.18)$} & \\
\hline $\begin{array}{l}\text { Stimulation } \\
\text { cost multiplier }\end{array}$ & NA & NA & $(0.9,2.6,5.0)$ & \\
\hline
\end{tabular}

\subsubsection{Cost Model Implementation}

Levelized cost of energy has been used in many renewable energy researches. It is a measurement of the overall competitiveness of a particular type of energy technology. It represents the cost per unit energy of building and operating an energy-providing technology over an assumed financial life (EIA, 2013). To this point, the capital costs and the O\&M costs of the surface facilities and the geothermal wells have been discussed. The levelized cost of thermal energy for GDHC systems was calculated by Equation 2.45 .

$$
L C O H=\frac{\sum(C A P+O M+P C)}{\sum G_{S}}
$$


Here a constant discount rate $r$ was used to discount future expense back to the present, and the project lifetime was assumed to be 30 years. The capital investment was calculated by Equation 2.46 .

$$
\sum C A P=\left(C A P_{\text {surface }}+C A P_{\text {well }}\right)
$$

Annual O\&M and pumping cost were calculated by Equation 2.47.

$$
\sum(O M+P C)=\left(O M_{\text {surface }}+O M_{\text {well }}+P C_{\text {surface }}+P C_{\text {well }}\right) \times \frac{(1+r)^{30}-1}{r \times(1+r)^{30}}
$$

The overall energy provided in 30 years was calculated by Equation 2.48.

$$
\sum G_{S}=G_{S} \times \frac{(1+r)^{30}-1}{r \times(1+r)^{30}}
$$

For all the resources, $C A P_{\text {surface }}$ is the sum of $C A P_{\text {pipe }}, C A P_{H X}$, and $C A P_{A C} ; C A P_{\text {well }}$ is the sum of $C A P_{\text {pump }}, C A P_{\text {drill }}$, and $C A P_{\text {expl }}$, noting that $C A P_{\text {well }}$ also includes $C A P_{\text {fracture }}$ for near hydrothermal EGS resources. The cost model calculated the $\mathrm{LCOH}$ for the 253 identified hydrothermal resources, 20 regions for the undiscovered hydrothermal resources, and the other 253 near hydrothermal EGS resources sequentially, and generated the supply curve.

\subsection{Thermal Potential for GDHC System}

\subsubsection{Identified Hydrothermal Resources}

Total available mass flow rate of each identified hydrothermal resource was first

estimated. A summary of the reservoir characteristics is in Appendix A-1. Figure 2.12 shows the histogram of the mass flow. It is seen that mass flow is mostly less than 120 $\mathrm{kg} / \mathrm{s}$, and therefore, a maximum of three production wells would be sufficient. 


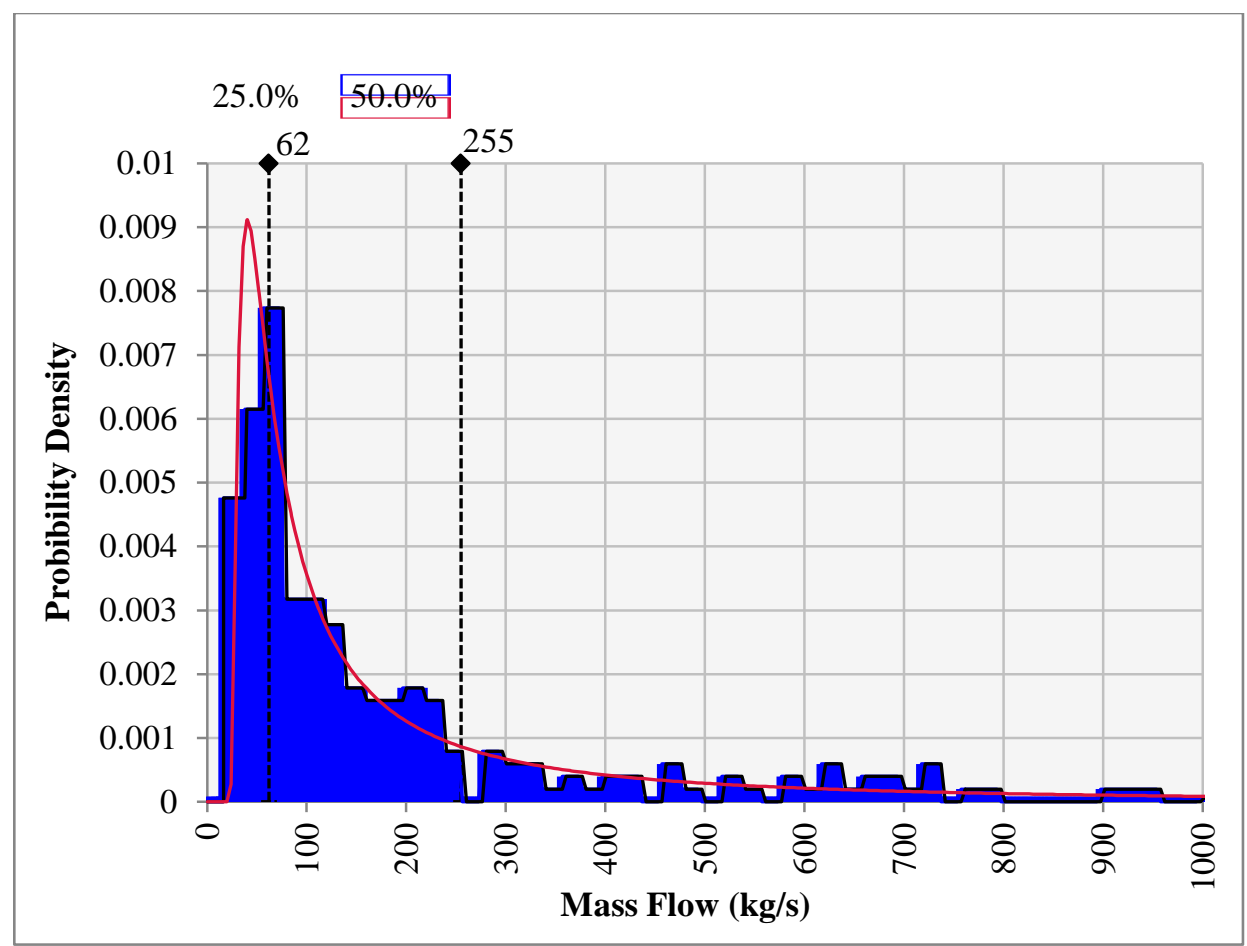

Figure 2.12: Histogram of the identified hydrothermal resources mass flow rates and the predicted probability density curve.

The overall thermal potential was then estimated with a mean of $72,577 \mathrm{MW}_{\text {th }}$, a $95 \%$ probability of $33,250 \mathrm{MW}_{\text {th }}$ and a $5 \%$ probability of $113,535 \mathrm{MW}_{\text {th }}$ by Monte Carlo simulations. Currently, there are quite a few numbers of resources already under development or in operation, mainly for geothermal power generation and space heating. The installed power generation capacity from identified hydrothermal resources is 2,479 $\mathrm{MW}_{\mathrm{e}}$ (Augustine, et al., 2011), and that of space heating is around $215 \mathrm{MW}_{\text {th }}$ (Lund, et al., 2011). If assuming an overall $10 \%$ efficiency of thermal energy to power generation, the remaining thermal potential from identified hydrothermal resources would have a mean of 47,566 $\mathrm{MW}_{\text {th. }}$ Figure 2.13 shows the pie chart of the hydrothermal potential distribution in each state, which shows that identified resources are concentrated in the state of California, Nevada, Alaska, and Oregon. 


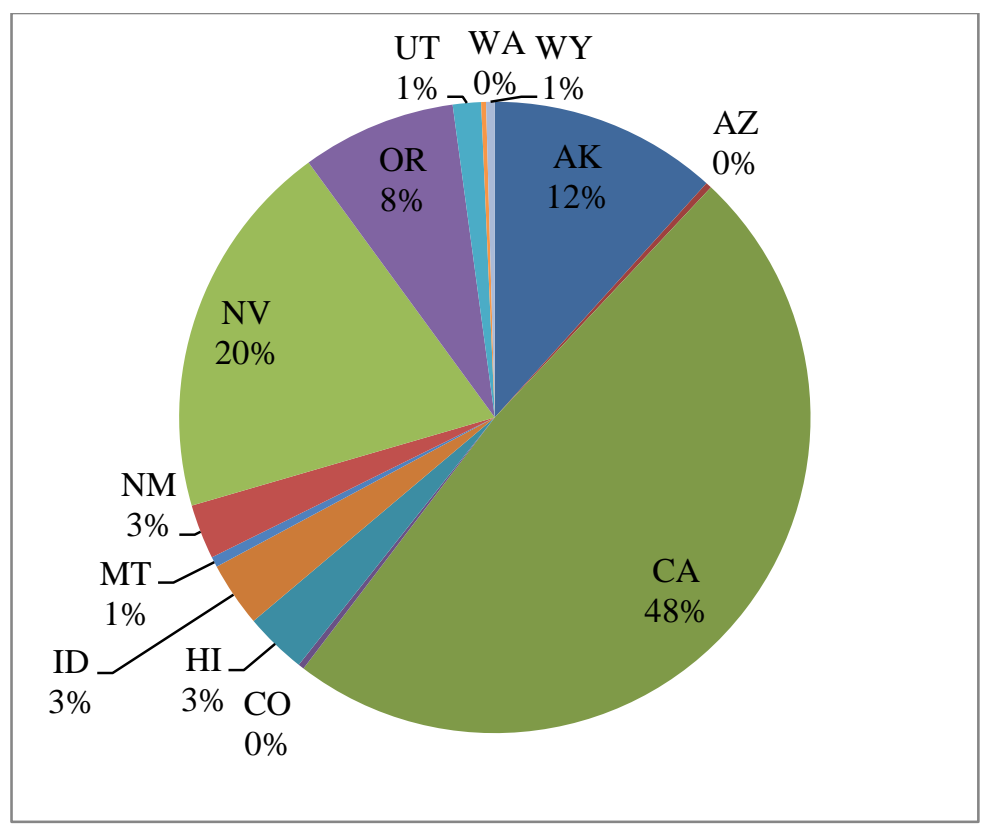

Figure 2.13: Pie chart of the remaining identified hydrothermal potential in each state, with a total of $47 \mathrm{GW}_{\text {th }}$.

\subsubsection{Undiscovered Hydrothermal Resources}

For undiscovered hydrothermal resources, the favorability factor presents the ratio of the undiscovered hydrothermal resources to the identified hydrothermal resource. The calculated favorability factor for each state is shown in Table 2.9.

Table 2.9: Favorability factor of different geothermal regions.

\begin{tabular}{|c|c||c|c|}
\hline Alaska & 2.64 & New Mexico & 1.13 \\
\hline Arizona & 0.71 & Nevada & 3.40 \\
\hline California & 1.50 & Oregon & 1.70 \\
\hline Colorado & 1.02 & Utah & 1.44 \\
\hline Hawaii & 13.45 & Washington & 0.39 \\
\hline Idaho & 1.85 & Wyoming & 0.59 \\
\hline Montana & 0.43 & & \\
\hline
\end{tabular}


A summary of the reservoir characteristics of the undiscovered hydrothermal resources is in Appendix A-2. Thermal potential of the undiscovered hydrothermal resources is calculated with a mean of $159,566 \mathrm{MW}_{\text {th }}$, a $95 \%$ probability of $70,953 \mathrm{MW}_{\text {th }}$, and a $5 \%$ probability of $253,071 \mathrm{MW}_{\text {th }}$. Figure 2.14 shows the pie chart of the undiscovered hydrothermal potential distribution in each state, which shows that undiscovered resources are concentrated in the state of California, Nevada, Hawaii, and Alaska. This is quite evident from the favorability map in Figure 2.4. And regions with more identified resources are more likely to have more undiscovered resources. Such states (CA, NV, HI, AK, OR) should be more focused when exploring geothermal energy.

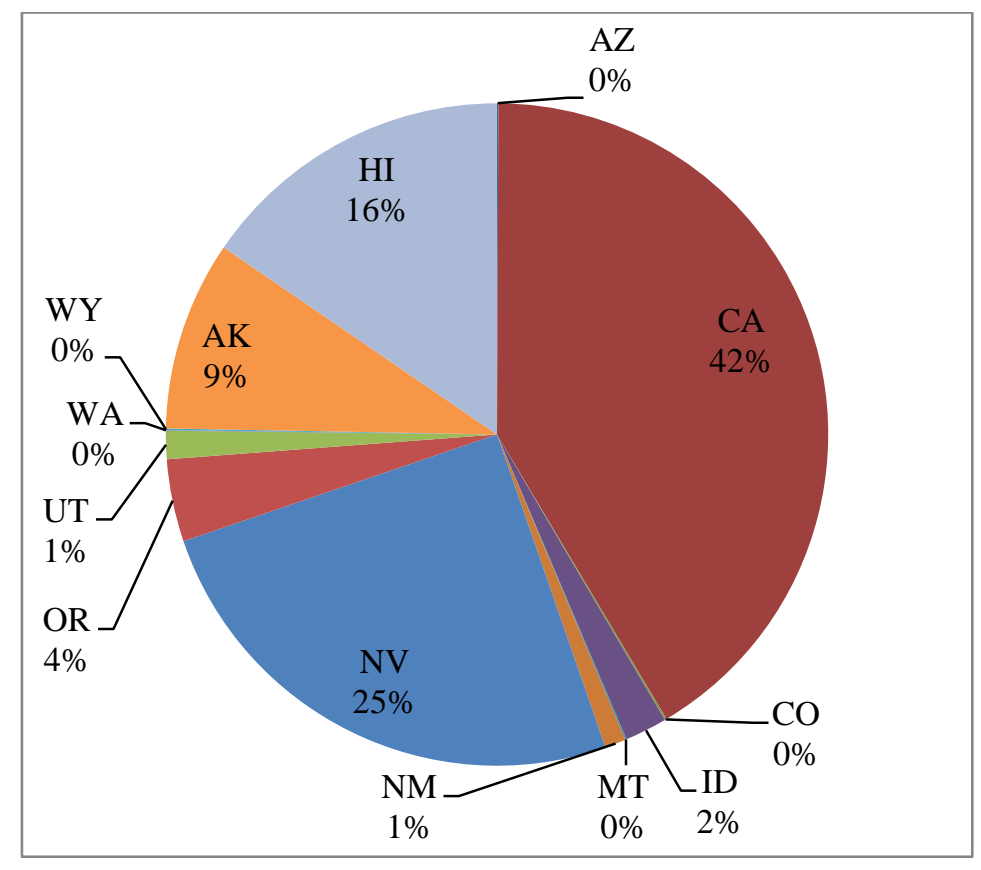

Figure 2.14: Pie chart of the undiscovered hydrothermal potential in each state, with a total of $159 \mathrm{GW}_{\mathrm{th}}$.

\subsubsection{Near Hydrothermal EGS Resources}

The near hydrothermal EGS has the same reservoir depth and temperature with its proximal hydrothermal reservoir. The thermal potential of each near hydrothermal EGS is the thermal potential difference between the mean and the high-end estimation of its corresponding hydrothermal resources. A list of the calculated near hydrothermal resource is shown in Appendix A-1. The overall thermal potential was estimated at 
$40,958 \mathrm{MW}_{\text {th. }}$. The top five resources with the most thermal potential were all found in California, which are Salton See area (8,393 $\left.\mathrm{MW}_{\text {th }}\right)$, Geysers area $\left(3,432 \mathrm{MW}_{\text {th }}\right)$, Brawley $\left(2,080 \mathrm{MW}_{\mathrm{th}}\right)$, Coso area $\left(1,415 \mathrm{MW}_{\mathrm{th}}\right)$, and Medicine Lake area (1,375 $\left.\mathrm{MW}_{\mathrm{th}}\right)$.

\subsection{LCOH Estimation and Supply Curve Development}

\subsubsection{Identified Hydrothermal Resources}

As stated in section 2.5, the GDHC system must be built at a populated location, so that the geothermal hot water can be consumed without much of the energy loss. There are some of the geothermal resources identified in this study with very few people living near them. With the levelized cost model, the calculated levelized costs at such locations were extremely high, more than $\$ 150 / \mathrm{MMBtu}$. In the following analysis, those locations with unreasonably high levelized cost are neglected. Figure 2.15 shows the calculated LCOH of the identified hydrothermal resources coupled with a geothermal temperature map at $6.5 \mathrm{~km}$. The color of the dot indicates the calculated $\mathrm{LCOH}$, while the size of the dot indicates the population size. A cost summary of each resource is shown in Appendix A1. All the resources with competitive levelized cost can be characterized as with median or high reservoir temperature, with median or low drilling depth, and with large population size. 


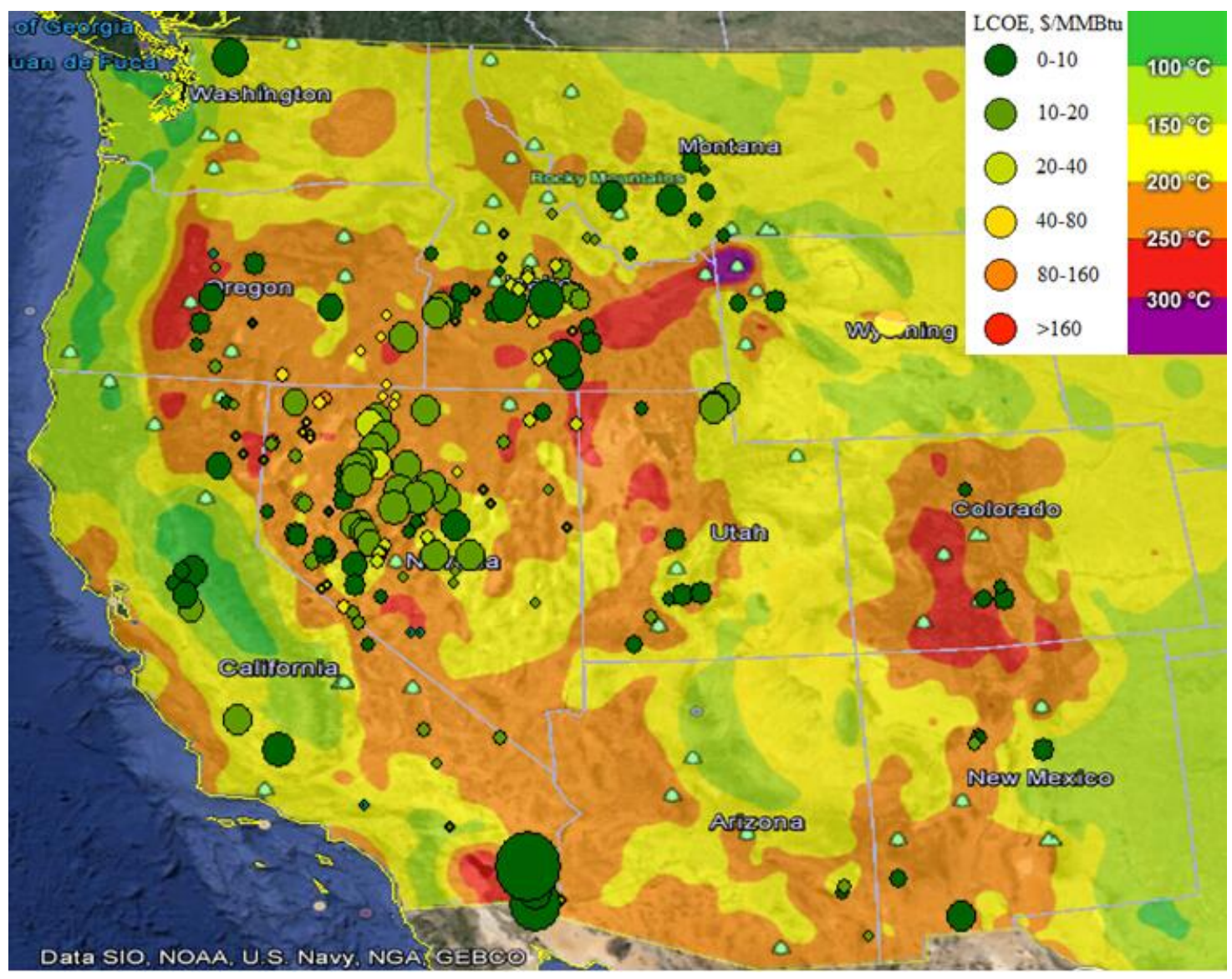

Figure 2.15: Maps of the identified hydrothermal resources, coupled with a western U.S. geothermal temperature map at $6.5 \mathrm{~km}$.

It is not practical to show the LCOH calculation of all the resources. Instead, Figure 2.16 shows the overall cost breakdown by sorting the resources into nine different categories by population and depth. The overall cost during 30 years is around $\$ 40$ to 60 million. It is clear that overall cost increases with the depth increases because of the significant well capital increase. The overall cost also increases with the population increases because of the significant surface capital increase. The surface capital dominates the investment when the drilling depth is smaller than 1000 meters, while the wells capital dominates the investment when the drilling depth is larger than 1000 meters. 


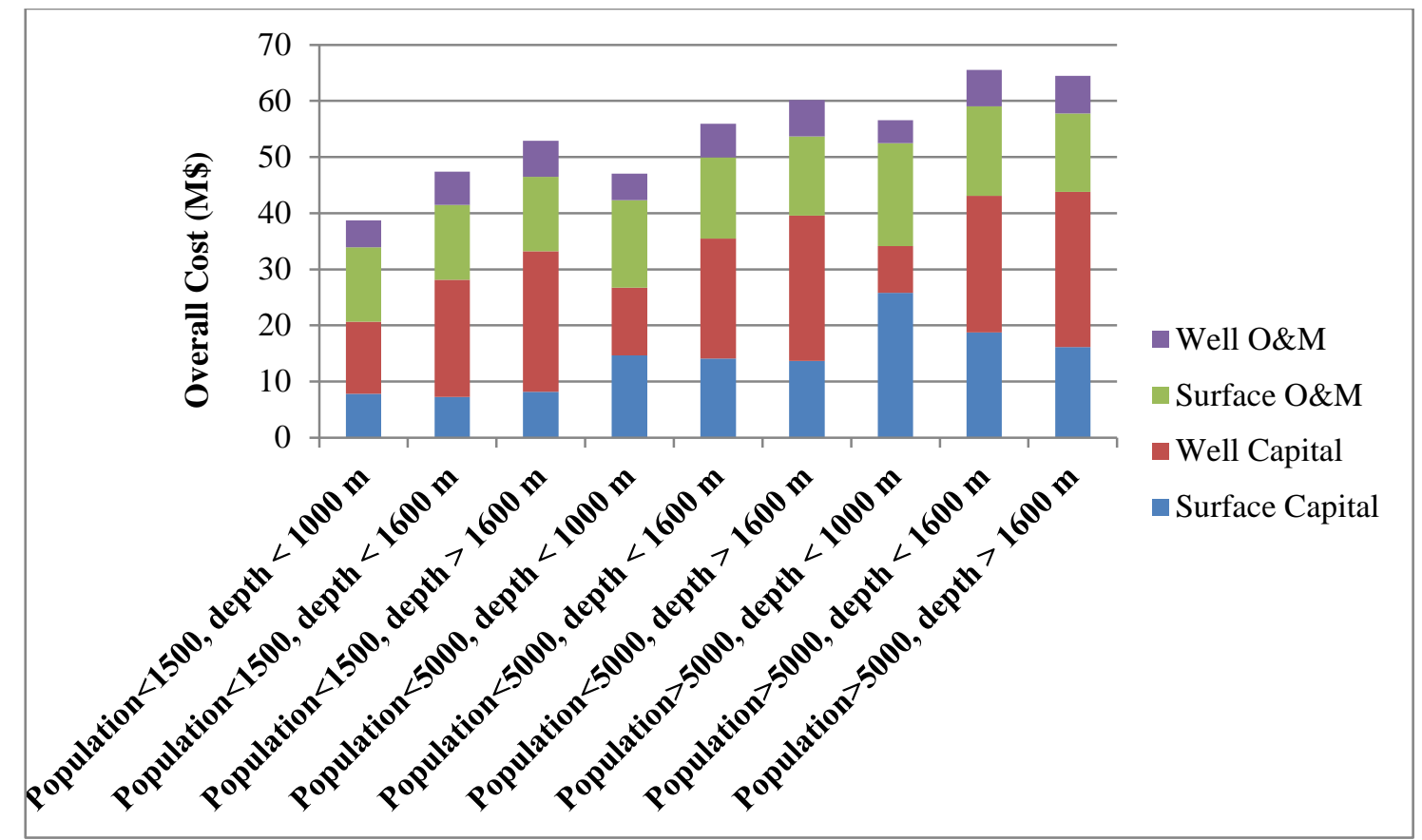

Figure 2.16: Cost breakdown of the GDHC projects of identified hydrothermal resources.

Among all the identified hydrothermal resources, the Weiser area in Idaho has the lowest levelized cost, at a mean of $\$ 6.74 / \mathrm{MMBtu}$. Table 2.10 shows the cost summary of the GDHC project at the Weiser area. The overall cost during 30 years is \$ 84 million, and the overall energy provided is $12.5 \times 10^{6} \mathrm{MMBtu}$.

Table 2.10: Cost summary for the simulated GDHC system at Weiser, ID.

\begin{tabular}{|c|c|c|}
\hline \multirow{4}{*}{ Capital Investment } & Wells Drilling & $16.9 \times 10^{6} \$$ \\
\cline { 2 - 3 } & $\begin{array}{c}\text { Wells Exploration \& } \\
\text { Miscellaneous }\end{array}$ & $3.0 \times 10^{6} \$$ \\
\cline { 2 - 3 } & Production Wells Pumps & $1.1 \times 10^{6} \$$ \\
\cline { 2 - 3 } & Injection Wells Pumps & $1.3 \times 10^{6} \$$ \\
\cline { 2 - 3 } & Surface Heating/Cooling & $1.9 \times 10^{6} \$$ \\
\cline { 2 - 3 } & Distribution System & $23.0 \times 10^{6} \$$ \\
\hline \multirow{4}{*}{ O\&M } & Wells Field & $0.4 \times 10^{6} \$ / y$ \\
\cline { 2 - 3 } & Surface Heating/Cooling & $1.6 \times 10^{6} \$ / \mathrm{y}$ \\
\cline { 2 - 3 } & System pumping & $0.4 \times 10^{6} \$ / \mathrm{y}$ \\
\hline
\end{tabular}


Figure 2.17 shows the year-round temperature profiles of the main streams of the surface heating/cooling facility, if the GDHC system is built at the Wesier area. The incoming temperature of the geothermal water $T_{p}$ is constant throughout the year at $90^{\circ} \mathrm{C}$. During the space heating days, the supply temperature of the hot water radiator $T_{s}$ increases with the ambient temperature $T_{a b}$ decreases due to heating demand increases. During the space cooling days, the geothermal hot water is directly used in the absorption chiller system. And the supply temperature $T_{s}$ is the same to the production temperature $T_{p}$.

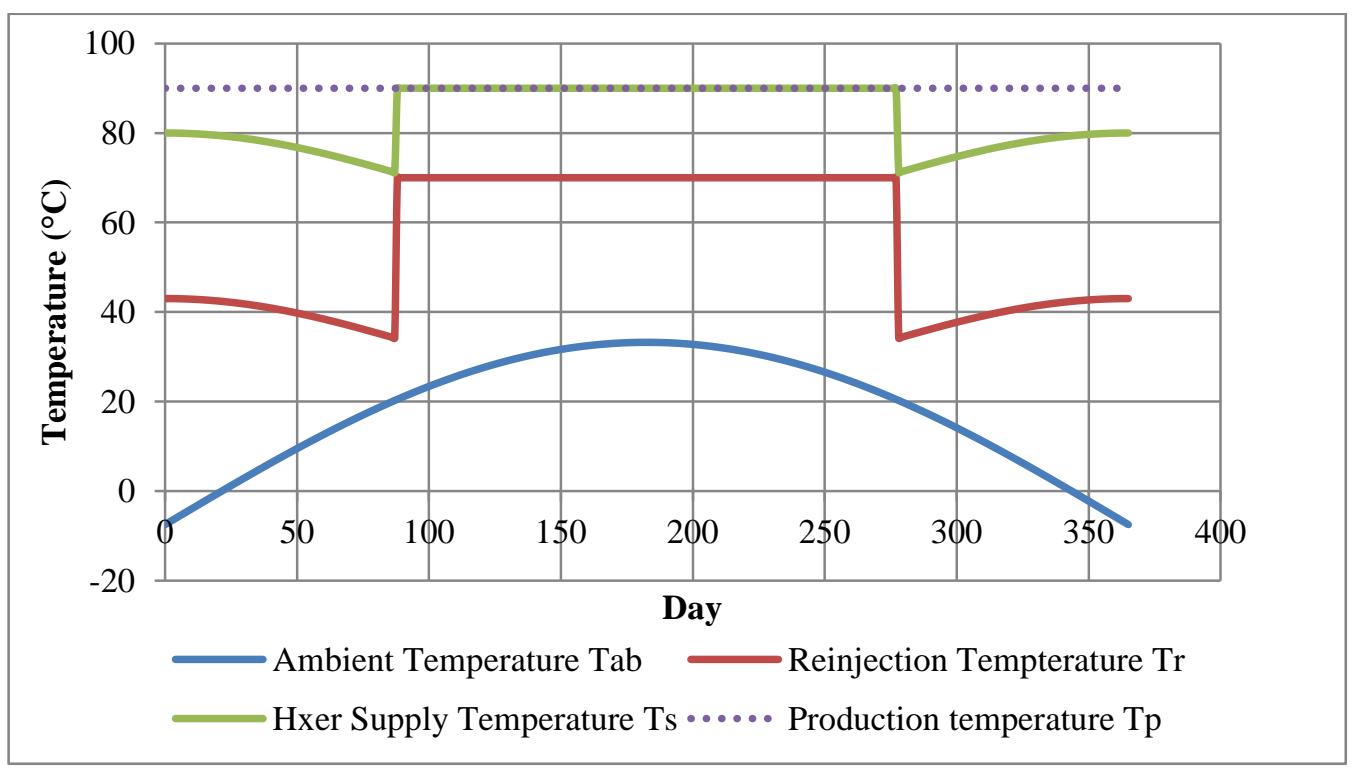

Figure 2.17: Temperature profile of main streams of the GDHC system in the Weiser area in Idaho.

Figure 2.18 shows the year-round mass flow rate profile of the geothermal production water regarding to the daily heating or cooling demand, if the GDHC system is built at the Wesier area. The maximum flow of production water is at the peak heating demand with $210 \mathrm{~kg} / \mathrm{s}$, which requires six production wells. Since the cooling demand is much smaller than the heating, the required flow rate in summer is therefore much less than that in winter. 


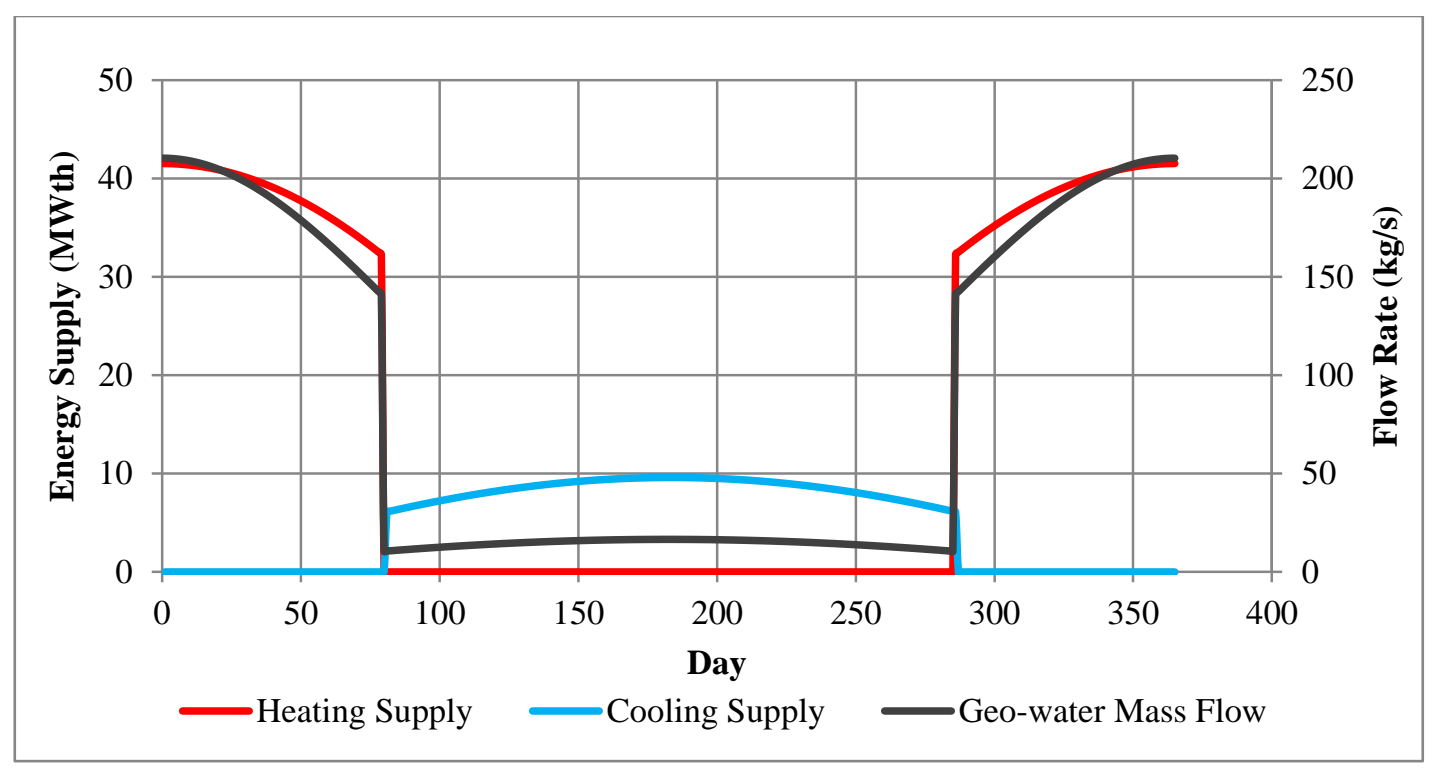

Figure 2. 18: Year-round flow rate profile of the geothermal production water of the GDHC system in the Weiser area in Idaho, corresponding to the daily system energy production.

The supply curve was then plotted based on each resource's paired thermal potential and the $\mathrm{LCOH}$. Here, as shown in Figure 2.19, the supply curve is truncated at $50 \mathrm{GW}_{\text {th }}$ to emphasize the resources with the lowest levelized cost, which are likely to be developed first. There are around 5 to $8 \mathrm{GW}_{\text {th }}$ of thermal energy which can be utilized under \$ 40/MMBtu. According to Edenhofer, et al., the cost of heating from any form of renewable energy becomes competitive to others when the price is not more than \$ 40/MMBtu (Edenhofer, et al., 2011). In comparison with the current cost of residential heating by natural gas, which is $\$ 9.2 / \mathrm{MMBtu}$ (EIA, 2013), there is only a very small amount of identified hydrothermal energy which can be utilized cheaper than this cost, while the most of the identified resources are still above that cost. 


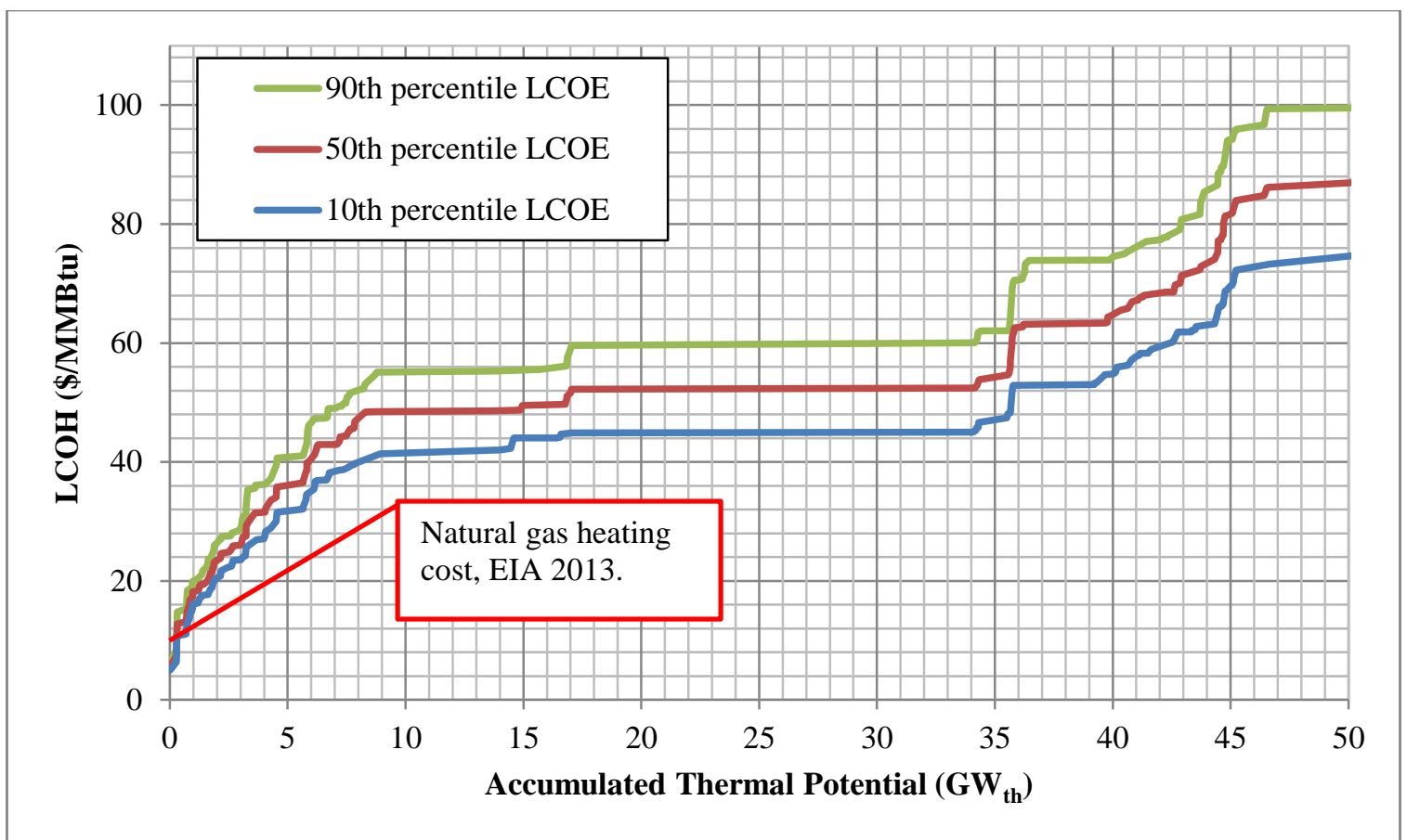

Figure 2.19: Supply curve of the identified hydrothermal resources, truncated at $50 \mathrm{GW}_{\text {th }}$, in comparison with the current cost of heating by natural gas, which is $\$ 9.2 / \mathrm{MMBtu}$.

\subsubsection{Undiscovered Hydrothermal Resources}

For undiscovered hydrothermal resources, the reservoir characteristics are more like the larger identified geothermal reservoirs in each region. However, the local energy demand cannot be determined since the location is unknown. When estimating the $\mathrm{LCOH}$ for this category of the resource, local energy demand was assumed to be that of the most populated place in that region. Figure 2.20 shows the overall cost breakdown of undiscovered hydrothermal resources. It is clear that overall cost still follows the trend as found from the identified ones, increasing with the increase in drilling depth and population. But for each column, the well capital increases because of the increasing exploration cost, and hence increase the overall cost. Among all the undiscovered resources, the ones in California with temperature greater than $150^{\circ} \mathrm{C}$ has the lowest LCOH at \$ 8.39/MMBtu. Table 2.11 shows the cost summary if the GDHC project built in that region. The overall cost during 30 years is $\$ 78$ million, and the overall energy provided is $9.3 \times 10^{6} \mathrm{MMBtu}$. 


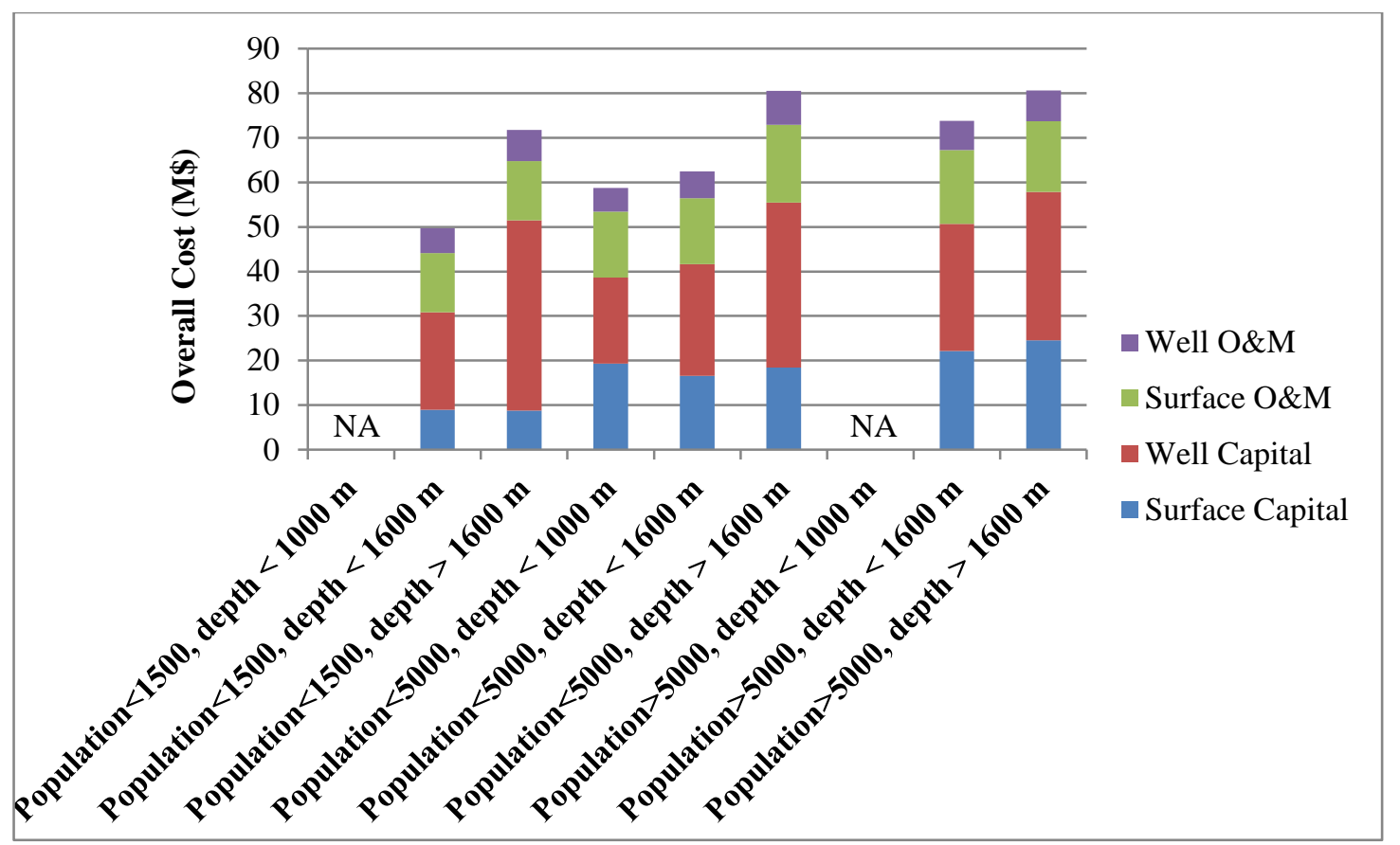

Figure 2.20: Cost breakdown of the GDHC projects of undiscovered hydrothermal resources.

Table 2.11: Cost summary for the simulated GDHC system in California with an undiscovered hydrothermal resource.

\begin{tabular}{|c|c|c|}
\hline \multirow{4}{*}{ Capital Investment } & Wells Drilling & $23.3 \times 10^{6} \$$ \\
\cline { 2 - 3 } & $\begin{array}{c}\text { Wells Exploration \& } \\
\text { Miscellaneous }\end{array}$ & $10.5 \times 10^{6} \$$ \\
\cline { 2 - 3 } & Production Wells Pumps & $0.56 \times 10^{6} \$$ \\
\cline { 2 - 3 } & Injection Wells Pumps & $0 \$$ \\
\cline { 2 - 3 } & Surface Heating/Cooling & $0.7 \times 10^{6} \$$ \\
\cline { 2 - 3 } & Distribution System & $19.8 \times 10^{6} \$$ \\
\hline \multirow{4}{*}{ O\&M } & Wells Field & $0.4 \times 10^{6} \$ /$ year \\
\cline { 2 - 3 } & Surface Heating/Cooling & $1.0 \times 10^{6} \$ /$ year \\
\cline { 2 - 3 } & System pumping & $0.1 \times 10^{6} \$ /$ year \\
\hline
\end{tabular}

The supply curve of the undiscovered hydrothermal resources is shown in Figure 2.21. There is about $65 \mathrm{GW}_{\text {th }}$ of the hydrothermal resources undiscovered in California which 
have a LCOH less than the current natural gas heating. Furthermore, there are up to 120 $\mathrm{GW}_{\text {th }}$ of undiscovered resources which have a LCOH less than $\$ 40 / \mathrm{MMBtu}$, which will be the most valuable resources, and to be developed first in future geothermal studies.

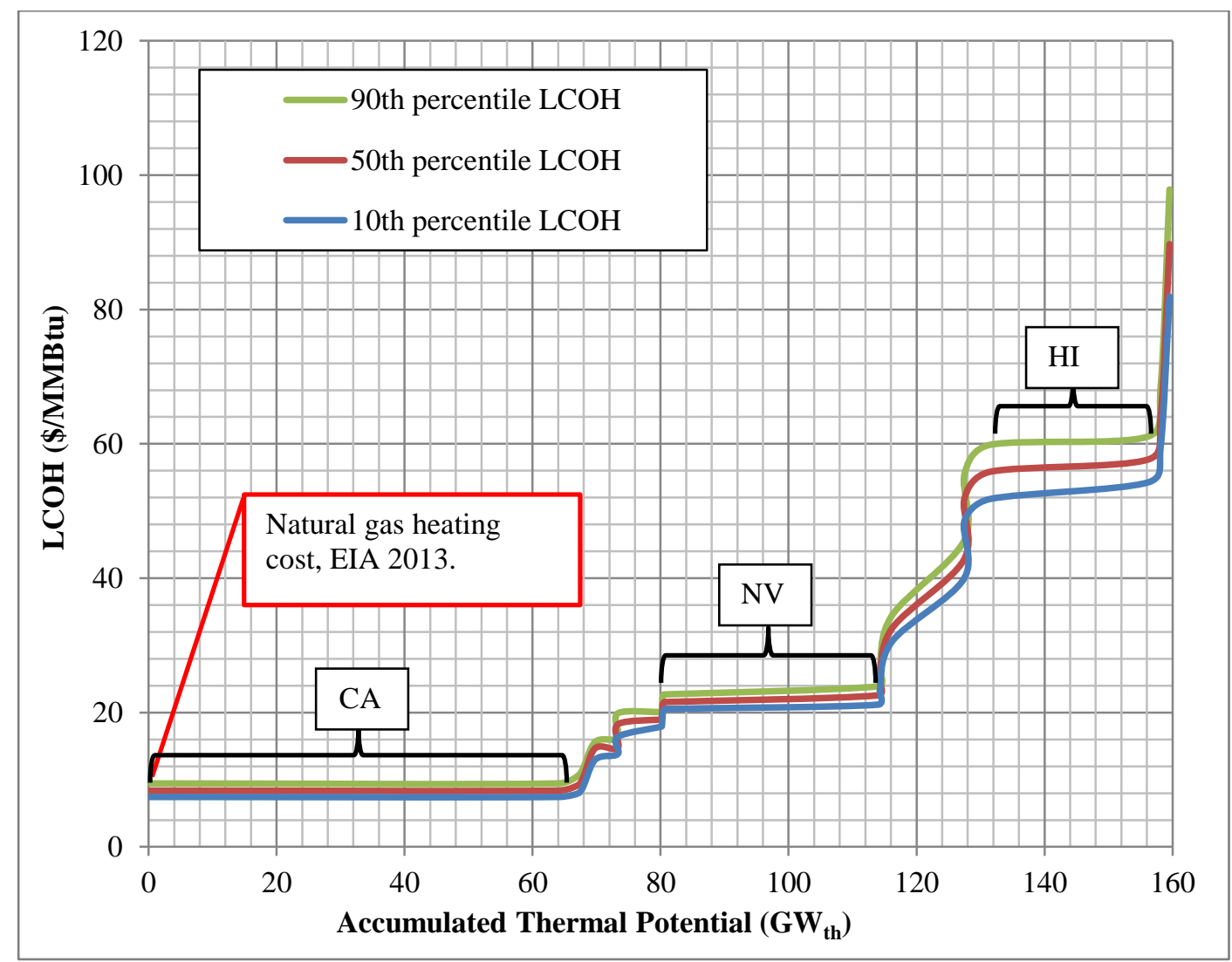

Figure 2.21: Supply curve of the undiscovered hydrothermal resources, in comparison with the current cost of heating by natural gas, which is $\$ 9.2 / \mathrm{MMBtu}$.

\subsubsection{Near Hydrothermal EGS Resources}

The LCOH of the near hydrothermal EGS is very similar to that of the identified hydrothermal ones, except that for the near hydrothermal EGS, artificial permeabilityincreasing technology (e.g. hydraulic fracturing) is required, which increases the well drilling capital. Among all the near hydrothermal EGS resources, the Weiser area in Idaho still has the lowest $\mathrm{LCOH}$ at $\$ 7.87 / \mathrm{MMBtu}$. The cost summary is similar to what is presented in Table 2.10, except that there is an added stimulation cost of about $\$ 13$ million to the well capital. The overall cost during 30 years is $\$ 91.6$ million, and the 
overall energy provided is $12.5 \times 10^{6}$ MMBtu. Figure 2.22 shows the supply curves of the near hydrothermal EGS resources with different flow rates.

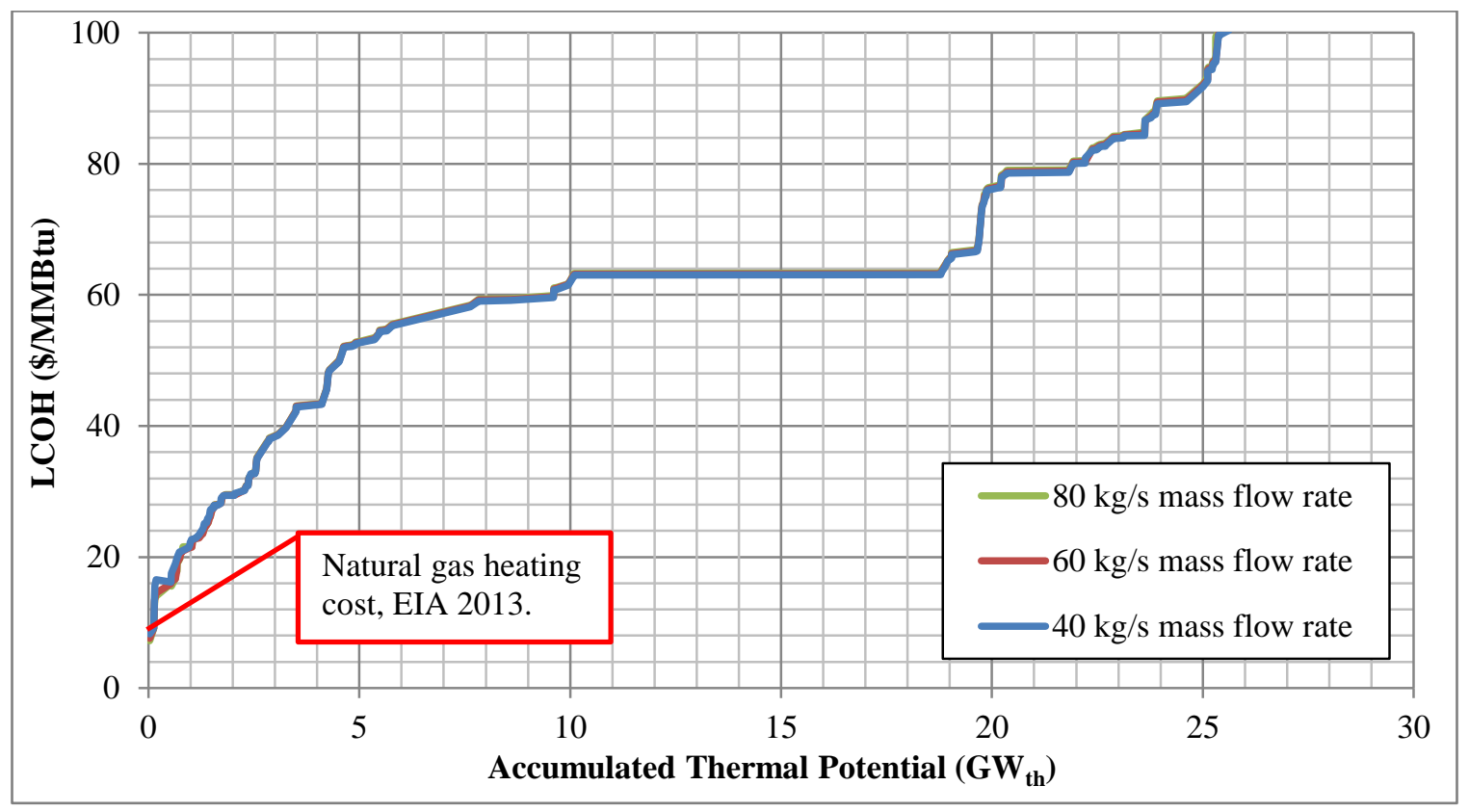

Figure 2.22: Supply curve of the near hydrothermal EGS, truncated at $\$ 100 / \mathrm{MMBtu}$, in comparison with the current cost of heating by natural gas, which is $\$ 9.2 / \mathrm{MMBtu}$.

Due to the uncertainty of the mass flow rate of each EGS reservoir, $40 \mathrm{~kg} / \mathrm{s}, 60 \mathrm{~kg} / \mathrm{s}, 80$ $\mathrm{kg} / \mathrm{s}$ were used as flow rate inputs for each case. Theoretically, with increasing flow rate, the levelized cost decreases because of the decreased number of production wells. The several resources at the left end of the supply curve in Figure 2.22 do follow such pattern: the levelized cost of the $80 \mathrm{~kg} / \mathrm{s}$ scenario is the lowest, while that of the $40 \mathrm{~kg} / \mathrm{s}$ scenario is the highest. For the other resources in this study, most locations only have a small energy demand, usually below $10 \mathrm{MW}_{\text {th }}$. Therefore, one production well with a $40 \mathrm{~kg} / \mathrm{s}$ water flow rate is sufficient to provide the energy demand. Increase in mass flow rate will not efficiently decrease the levelized cost. As a result, supply curves for the three different mass flow rate scenarios overlap for the most parts as shown in Figure 2.22. 


\subsubsection{The GDHC Supply Curve}

Figure 2.23 shows the supply curve of three categories of geothermal resources, Figure 2.24 combines them together, and Figure 2.25 partially enlarges the part with reasonable cost. The near hydrothermal EGS resource is always coupled with its corresponding hydrothermal one with a slightly higher cost. Since most of the low cost hydrothermal resources have already been developed into power generation, their corresponding EGS resources may be good choices for expanding the existing system. There are also a large amount of hydrothermal resources undiscovered with a very low $\mathrm{LCOH}$, which deserve more attentions in the future geothermal exploration.

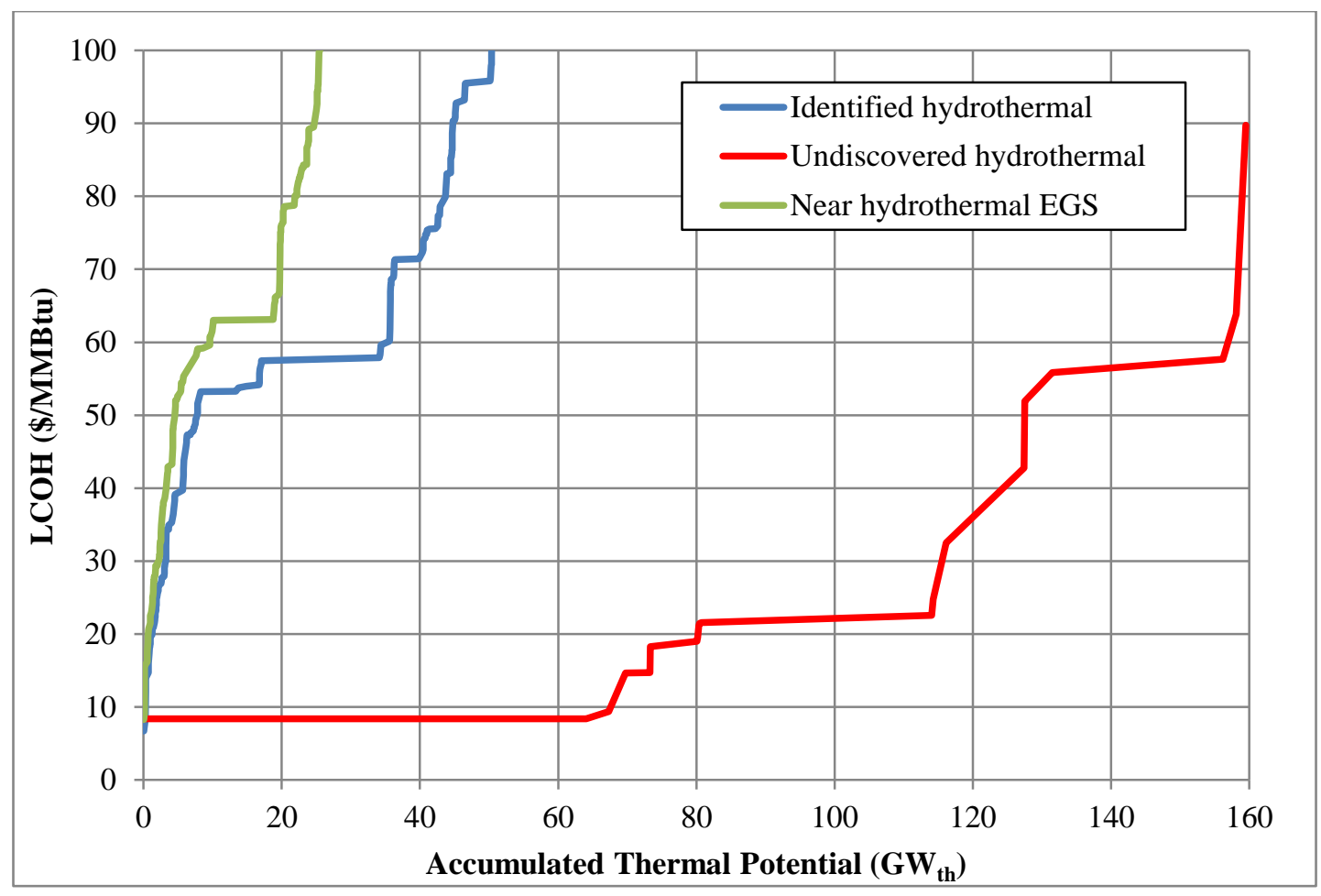

Figure 2.23: Supply curve of the U.S. GDHC application with different categories of geothermal resources. 


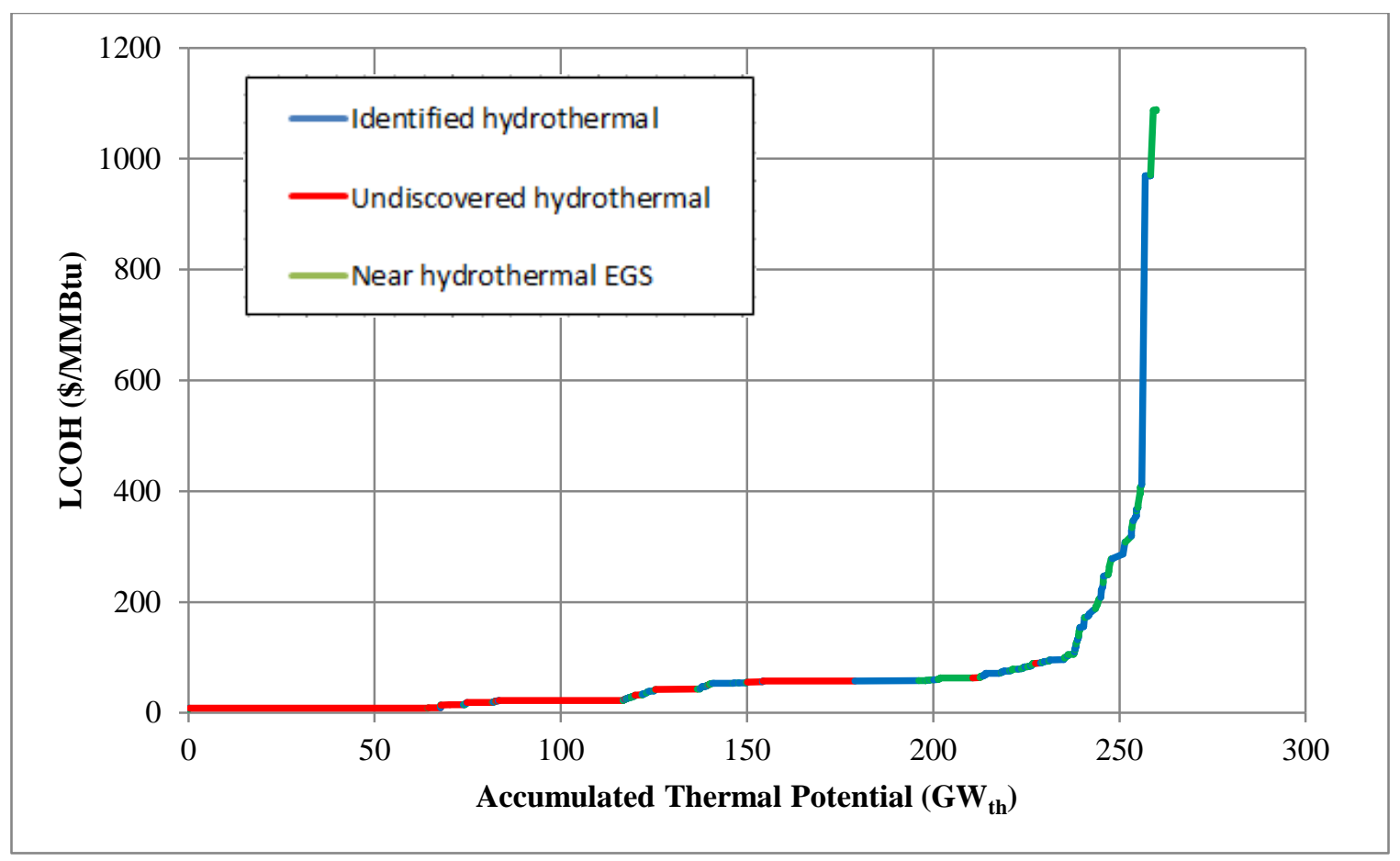

Figure 2.24: Supply curve of the U.S. GDHC application.

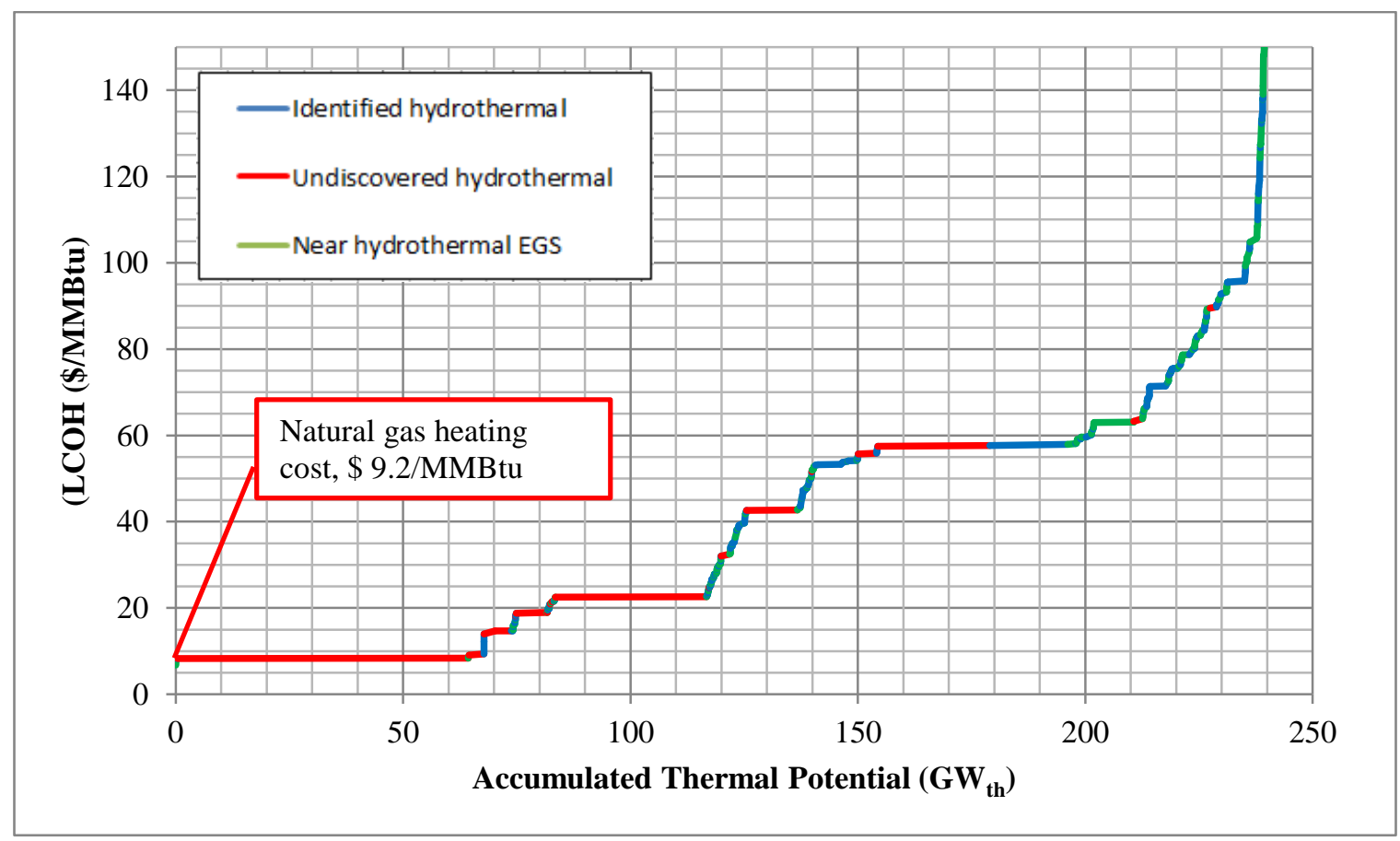

Figure 2.25: Partial enlargement of the supply curve, in comparison with the current natural gas heating cost, which is $\$ 9.2 / \mathrm{MMBtu}$. 


\subsection{Discussion}

Discussions of the $\mathrm{LCOH}$ in this part of the study are based on results from identified hydrothermal resources and near hydrothermal EGS resources. Some of the system inputs such as population and reservoir gradient are uncontrolled factors. The following part discusses such uncontrolled factors' effects on the LCOH.

\subsubsection{Population's Effect on LCOH}

The population has a significant effect on the LCOH of a GDHC system. Figure 2.26 shows the population served by the identified hydrothermal resources based GDHC systems versus their $\mathrm{LCOH}$. It shows that a resource with a larger population tend to have a lower $\mathrm{LCOH}$, while a resource with a smaller population tend to have a higher $\mathrm{LCOH}$. The predicted trend line in Figure 2.26 was fitted with a polynomial function by the least square error regression analysis, as shown in Equation 2.49. A larger population means a larger annual energy production, which is the denominator of the LCOH calculation, and hence decreases the $\mathrm{LCOH}$. However, a larger population also means larger surface heating/cooling facilities, a larger distribution network, and more production wells. Thus, the constant in Equation 2.49 can be interpreted as the minimum LCOH with saturated population of a particular location.

$$
L C O H=10202 \times p p l^{-0.7495}+1.6469
$$




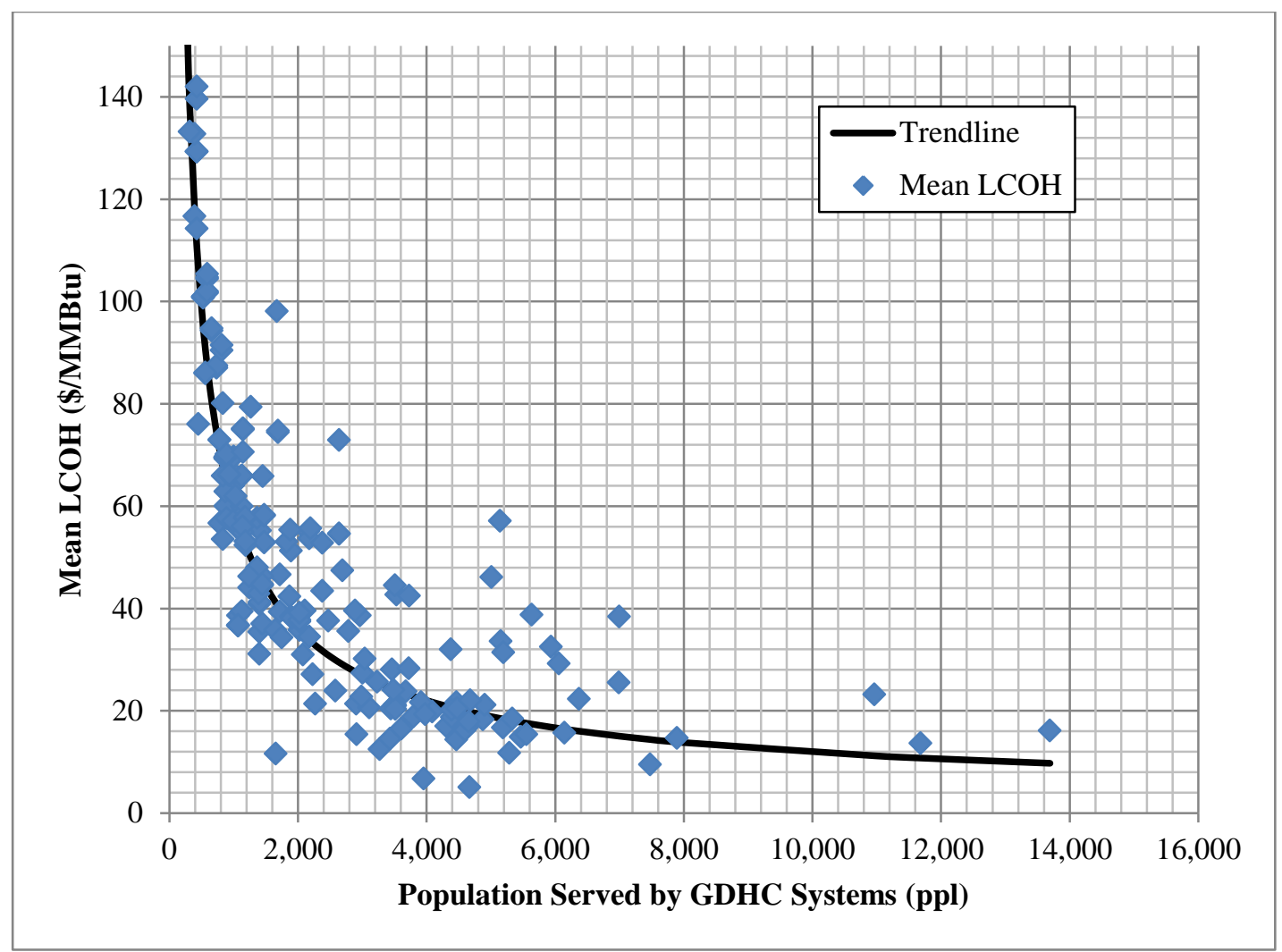

Figure 2.26: Population served by identified hydrothermal resource based GDHC systems versus their $\mathrm{LCOH}$. Blue dots are identified resources, and the trend line shows the predicted $\mathrm{LCOH}$ as a function of the population.

\subsubsection{Geothermal Gradient's Effect on LCOH}

The effect of the geothermal gradient is not significant to the $\mathrm{LCOH}$, but locations with higher gradients still tend to have a lower LCOH, as shown in Figure 2. 27. Most of the geothermal gradients of the identified resources are less than $0.2^{\circ} \mathrm{C} / \mathrm{m}$, while the corresponding LCOH range from \$ 10 to 140 per MMBtu. For hydrothermal resources and near hydrothermal EGS resources, the reservoir depths are fixed. Efforts to lower the drilling depth cannot ensure sufficient mass flow rate. This is the reason why gradient has little effect on the LCOH. However, it can be predicted that for a deep EGS based project, a higher gradient means less drilling capital and a higher production temperature and surely, a decrease in the LCOH. 


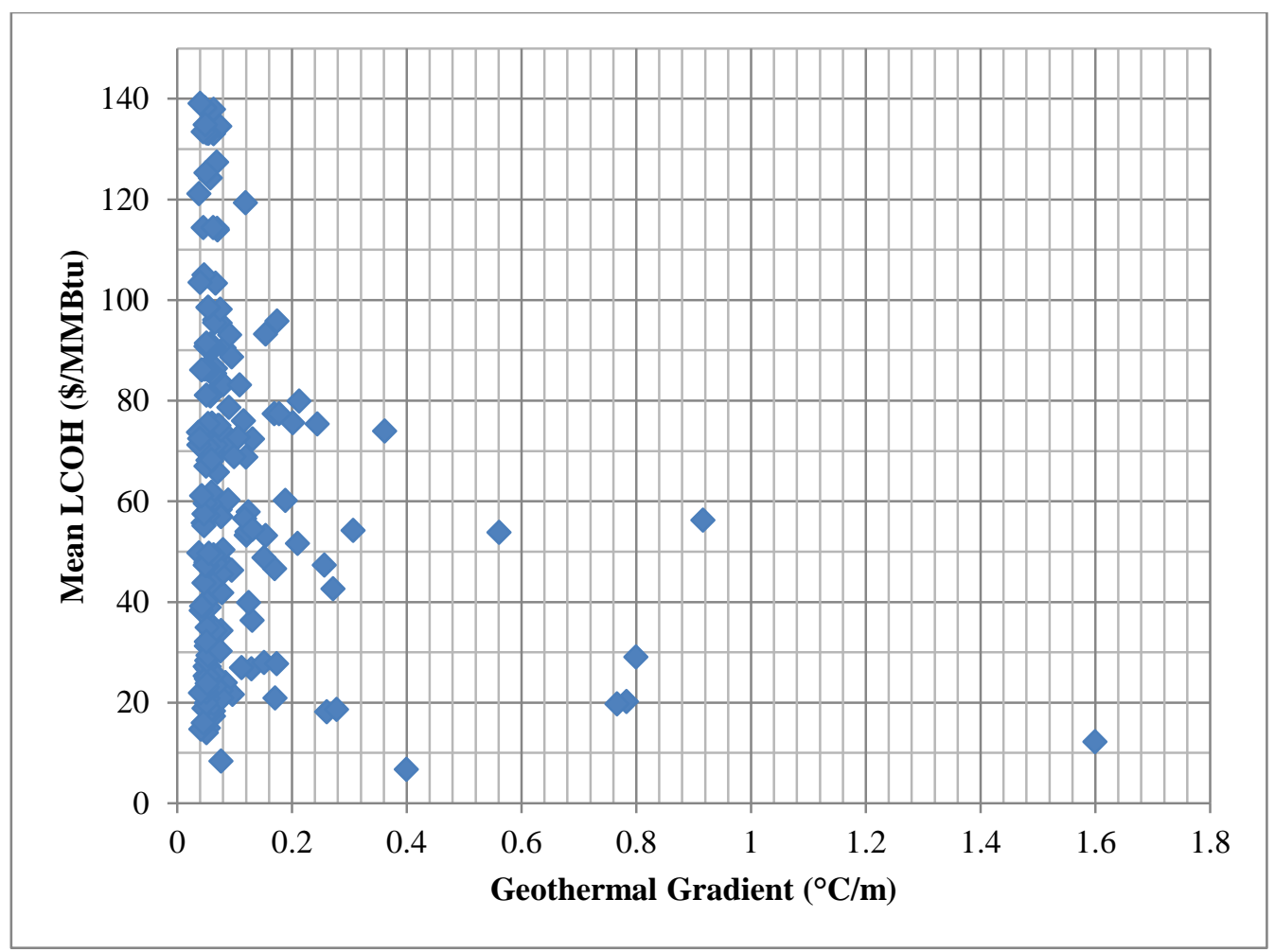

Figure 2.27: Geothermal gradients of the identified hydrothermal resources versus their calculated LCOH for the GDHC systems.

\subsubsection{Model Sensitivity}

To determine the sensitivity of the cost model, six technical or economic parameters from the model were selected, which are the energy demand, reservoir temperature, drilling cost, project lifetime, discount rate, and surface capital. Simulations were run for each parameter with $-50 \%,-25 \%,+25 \%$ and $+50 \%$ changes while the others stayed constant. Corresponding $\mathrm{LCOH}$ changes based on varies of the parameter were recorded. Results of the sensitivity analysis are shown in Figure 2.28. The energy demand has the most significant negative effect, while drilling cost has the most significant positive effect on $\mathrm{LCOH}$. Moreover, increasing the energy demand is the most effective way to decrease $\mathrm{LCOH}$. The project lifetime and reservoir temperature also have a negative effect on $\mathrm{LCOH}$, while surface capital and discount rate have a positive effect on $\mathrm{LCOH}$. 


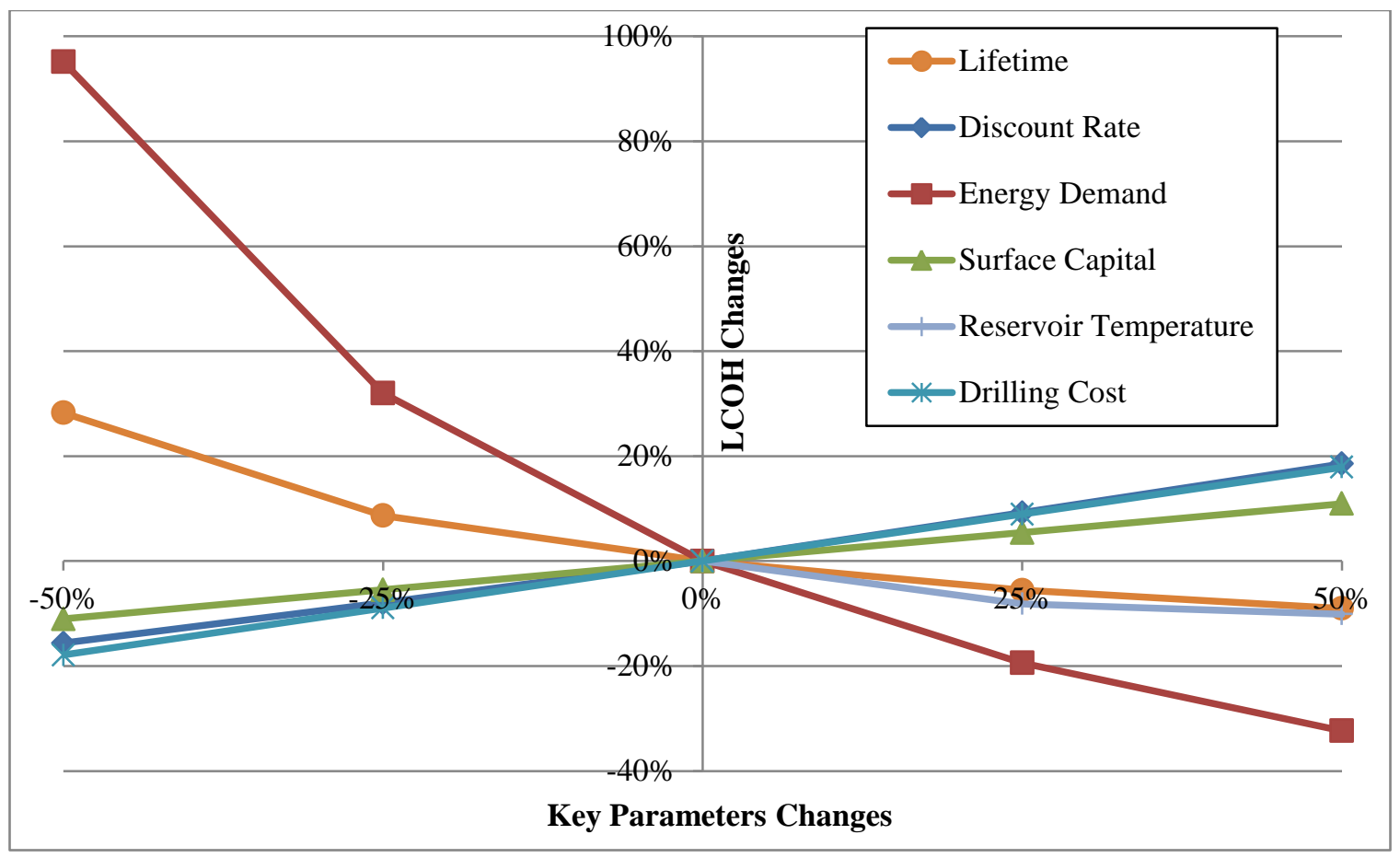

Figure 2.28: Sensitivity analysis of the cost model, showing energy demand has the most significant negative effect, while drilling cost has the most significant positive effect.

\subsection{Conclusion}

This part of the study focuses on the supply curve of geothermal district heating and cooling application. Geothermal resources were categorized into identified hydrothermal resources, undiscovered hydrothermal resources, near hydrothermal EGS resources and the deep EGS resources. Owing to the high cost of the deep EGS resources, only the first three categories have been discussed in this part of the study. 253 hydrothermal resources were identified from literature review, and 253 near hydrothermal EGS resources were assumed. Due to the uncertainties of the undiscovered resources, this category of hydrothermal resources was estimated by calculating their occurrence possibility in each state. As a summary, estimated thermal potential from each category of the resources is presented in Table 2.12. Following the fact that nearly half of the identified hydrothermal resources have already been developed into other applications such as power generation, the remaining potential from this category is about $47,566 \mathrm{MW}_{\text {th }}$, which is concentrated in the states of California, Nevada, Alaska, and Oregon. Estimated thermal potential from 
the undiscovered hydrothermal resources is about $159,566 \mathrm{MW}_{\mathrm{th}}$, which is concentrated in the states of California, Nevada, Hawaii, Alaska, and Oregon. Estimated thermal potential from the near hydrothermal EGS resources is about $40,958 \mathrm{MW}_{\text {th }}$.

Table 2.12: Estimated thermal potential and the corresponding lowest $\mathrm{LCOH}$ from the western U.S. geothermal resources.

\begin{tabular}{|c|c|c|c|c|}
\hline $\begin{array}{c}\text { Identified } \\
\text { hydrothermal } \\
\text { resources }\end{array}$ & $\begin{array}{c}5 \text { Percentile, } \\
\mathrm{MW}_{\text {th }}\end{array}$ & $\begin{array}{c}50 \text { Percentile, } \\
\mathrm{MW}_{\text {th }}\end{array}$ & $\begin{array}{c}\text { 95 Percentile, } \\
\mathrm{MW}_{\text {th }}\end{array}$ & $\begin{array}{c}\text { Lowest LCOH, } \\
\$ / \mathrm{MMBtu}\end{array}$ \\
\hline $\begin{array}{c}\text { Undiscovered } \\
\text { hydrothermal } \\
\text { resources }\end{array}$ & 70,953 & 159,566 & 253,071 & 6.74 \\
\hline $\begin{array}{c}\text { Near } \\
\text { hydrothermal } \\
\text { EGS }\end{array}$ & 40,958 & & 8.39 \\
\hline
\end{tabular}

This study also developed a cost model for the GDHC system, which enables a matrix of 20 user-defined inputs to characterize the geothermal resources as well as the target energy demand. The cost model was used for every resource to simulate the lifetime heating/cooling process, capital investment, and operation and maintenance activities. As a result, the lowest $\mathrm{LCOH}$ of identified hydrothermal resources to develop a GDHC system is at Weiser in Idaho, with a LCOH at \$6.74/MMBtu. That of the undiscovered hydrothermal resources is estimated at $\$ 8.39 / \mathrm{MMBtu}$ in the state of California, and that of the near hydrothermal EGS resources is \$7.87/MMBtu, also at Weiser in Idaho. For similar geologic settings, LCOH for the identified hydrothermal resource is the lowest, while that for the undiscovered hydrothermal resource is the highest because of the high exploration cost. All the resources with competitive levelized cost can be characterized as with a median or high reservoir temperature, a median or low drilling depth, and with a large population size. Analysis of the results revealed that population has significantly 
greater effect on $\mathrm{LCOH}$ than geothermal gradient. The energy demand has the most significant negative effect, while drilling cost has the most significant positive effect on $\mathrm{LCOH}$. Increasing the energy demand is the most effective way to decrease $\mathrm{LCOH}$.

Finally, the supply curve of GDHC application was developed. It shows the order in which resource should be developed based on the $\mathrm{LCOH}$ results. There are about $50 \%$ of the thermal potential with a levelized cost lower than $\$ 40 / \mathrm{MMBtu}$. With the exception of the lowest cost of the identified hydrothermal resource (Weiser area, ID) and its corresponding EGS resource, over $60 \mathrm{GW}_{\text {th }}$ of the potential is still undiscovered, with a cost lower than the natural gas heating. Moreover, there is another $35 \mathrm{GW}_{\text {th }}$ of the undiscovered hydrothermal resources with $\mathrm{LCOH}$ between less than $\$ 25 / \mathrm{MMBtu}$. The near hydrothermal EGS is the least expensive type of EGS resource. The levelized cost of the near hydrothermal EGS is a little higher than its corresponding identified hydrothermal resource. Thus in the supply curve, the near hydrothermal EGS and the identified hydrothermal resource are usually coupled. In fact, there is not much thermal potential available from identified hydrothermal resources, since most of the low cost resources have already been developed with other applications such as power generation. So the near hydrothermal EGS corresponding to the most competitive identified hydrothermal resources may be a good choice for expanding the existing system. 


\section{Chapter 3}

\section{Techno-Economic Assessment of GDHC Systems: A Case Study on West Virginia University}

\subsection{Introduction}

Geothermal energy has the advantages of sustainable energy output with a high capacity factor, but hydrothermal geothermal resources only exist in very few locations worldwide. Exploitable geothermal resources require three elements at the same time, which are the hot enough reservoir, the water itself, and permeable subsurface structure so that the hot water could be delivered to the surface. However, most of the geothermal resources consist of impermeable subsurface structure. Therefore, technology of the enhanced geothermal system (EGS) would be used to enhance the rock permeability by injecting large amounts of water into the reservoir.

Currently there is no large scale commercial EGS project, but only experimental activities operating all over the world. For example, the Fenton Hill geothermal power plant in New Mexico, U.S. with a net capacity of $5 \mathrm{MW}_{\mathrm{e}}$, and the pilot plant in Soultz, France with a net capacity of $1.5 \mathrm{MW}_{\mathrm{e}}$ (Tenzer, 2001). Augustine estimated that levelized cost of EGS power generation is at least $\$ 0.27 / \mathrm{kWh}$ (Augustine, et al., 2010).

Preliminary study shows that low temperature end uses such as space and water heating, and air conditioning contribute up to $25 \%$ of the U.S. annual energy consumption. Developing geothermal district heating and cooling (GDHC) systems based on EGS could efficiently decrease the fossil fuels usage for such low temperature applications, especially in the populated eastern U.S. where hydrothermal resources are not common. This part of the study proposes an EGS based GDHC system on the campus of West 
Virginia University (WVU) to evaluate its competitiveness as compared to the existing steam based heating and cooling system. Based on this case study, empirical functions for solving LCOH for EGS based GDHC systems are developed and the potential locations in West Virginia for developing such systems mapped. The objective is to provide a techno-economic benchmark for future EGS based GDHC systems development.

\subsection{The Initial: West Virginia Geothermal Hot Spot}

In 2010, Frone, Richards, and Blackwell at Southern Methodist University (SMU) Geothermal Lab identified elevated geothermal temperatures in West Virginia. With the updated data from oil and gas field, the new temperature profile is significantly higher than the previously estimated in the MIT report - The Future of Geothermal Energy (Tester, et al., 2006). The high temperature geothermal region extends from the north central WV i.e. from Monongalia County where WVU is located, to Greenbrier County in the southeastern WV. This part of the study evaluates the potential to develop the EGS based GDHC systems in the state of West Virginia, beginning with a case study on West Virginia University campus.

Geothermal energy is essentially a ubiquitous resource for which its economics vary regionally. The resource availability on the supply side and the energy consumption on the demand side must be carefully evaluated when examining a potential geothermal project. The large size energy consuming population, dense arrangement of the campus buildings, and the elevated geothermal temperature profile, makes West Virginia University a potential location for the GDHC development.

The geologic cross section $D-D^{\prime}$ (Ryder, et al., 2009) from the U.S. Geologic Survey is the nearest geologic cross section to illustrate the geologic framework at WVU, as shown in Figure 3.1, which suggests no massive aquifer layer beneath WVU. WVU is located about $20 \mathrm{~km}$ north of the well (API 47-049-00244) owned by the Phillips Petroleum Company, as shown in Figure 3.1. The 100-meter-thick Tuscarora Sandstone at depth 3.3 $\mathrm{km}$ (10000 feet) is of interest, as the successful EGS project at Gross Schoenebeck in Germany also has very similar geologic conditions with that of West Virginia, as shown 
in Table 3.1. The wells at Gross Schoenebeck were successfully stimulated by massive water fracture treatment which is a common reservoir fracturing method in oil industry, and an economical productivity was reached for a $70 \mathrm{~kW}$ geothermal power plant. The 30-meter-thick Oswego Sandstone at depth $3.6 \mathrm{~km}$ (12000 feet) is also of interest. The Oswego formation extends along the Appalachian basin to the central New York state where horizontal wells have been drilled, making it the fourth largest natural gas production formation in the state of New York (NYSDEC, 2011), suggesting that sufficient permeability may also be reached with proper stimulation at WVU.

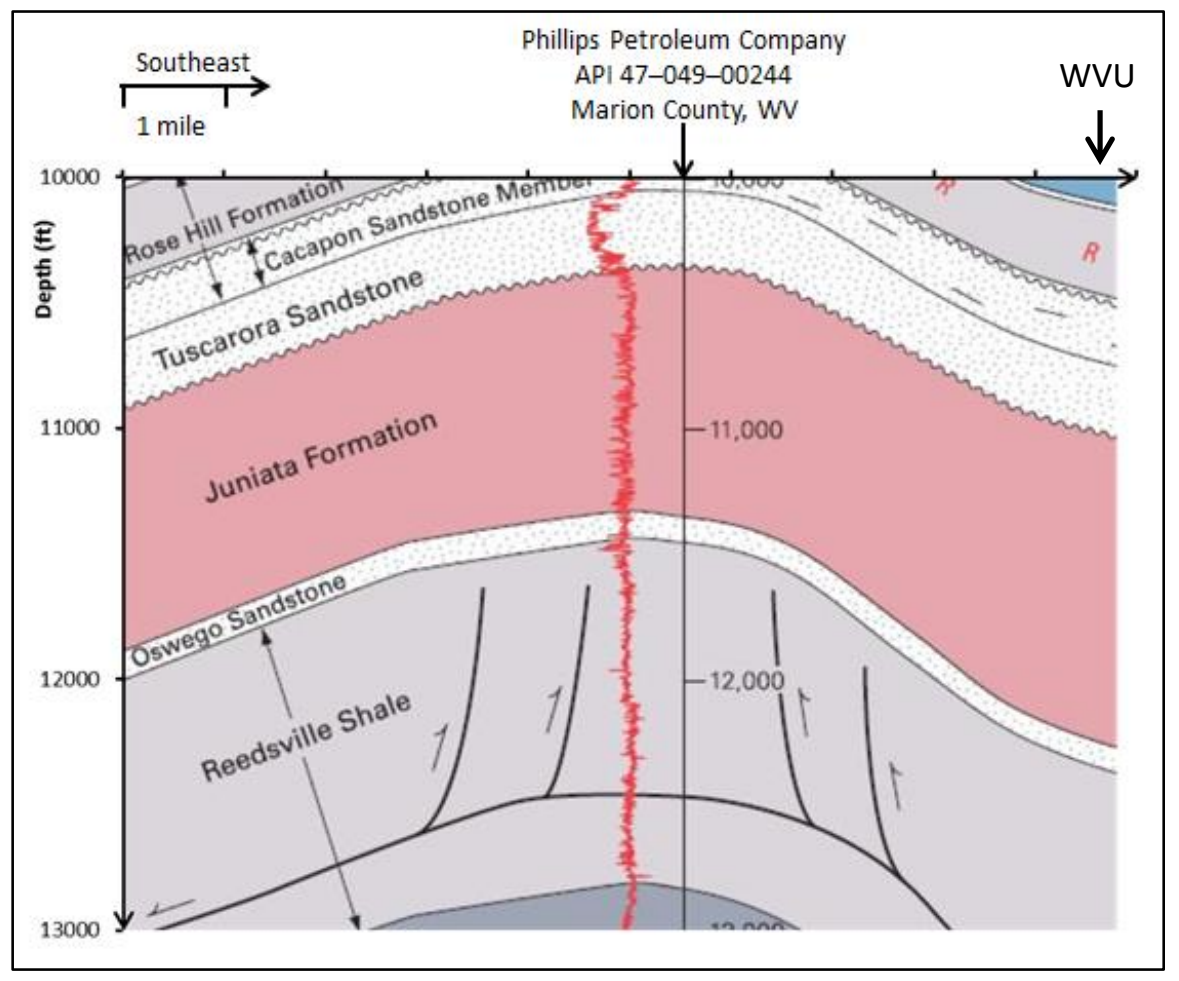

Figure 3.1: Geologic formations near Morgantown, WV at depth of 3 to $4 \mathrm{~km}$, the Tuscarora and Oswego Sandstone are of interest for GDHC development. 
Table 3.1: Comparison of the geologic conditions between Gross Schoenebeck and Morgantown, WV, data from Hurter, et al. (Hurter, et al., 2002) and Castle and Byrnes (Castle and Byrnes, 2005).

\begin{tabular}{|c|c|c|c|c|}
\hline & Rock Type & Depth, $\mathrm{m}$ & $\begin{array}{c}\text { Average } \\
\text { Permeability, mD }\end{array}$ & $\begin{array}{c}\text { Average } \\
\text { Porosity, \% }\end{array}$ \\
\hline \multirow{2}{*}{$\begin{array}{c}\text { Gross } \\
\text { Schoenebeck }\end{array}$} & Conglomerates & $\begin{array}{c}4200 \text { to } \\
4230\end{array}$ & 0.003 & 4.8 \\
\cline { 2 - 5 } & Volcanics & $\begin{array}{c}4230 \text { to } \\
4294\end{array}$ & 0.005 & 4.3 \\
\hline WVU & $\begin{array}{c}\text { Tuscarora } \\
\text { Sandstone }\end{array}$ & $\begin{array}{c}3200 \text { to } \\
3350\end{array}$ & 0.0048 & 6.8 \\
\hline
\end{tabular}

\subsection{Modeling the GDHC System on WVU Campus}

This case study aims to find the levelized cost of heat ( $\mathrm{LCOH})$ for GDHC system on the Evansdale campus, WVU, to replace the current steam based heating and cooling system. Peak heating and cooling demand were estimated to determine the necessary amount of geothermal hot water production as well as to design the surface energy conversion facilities. Aspen Plus models of the geothermal water distribution network with building heating units and a centralized $\mathrm{H}_{2} \mathrm{O} / \mathrm{LiBr}$ absorption chiller system were built to simulate the heating and cooling scenarios with various geothermal temperatures and flow rate profile. Cost estimation including cost of drilling geothermal wells, capital cost of surface equipment and operation and maintenance costs were made. Five pairs of temperature and flow rate cases were simulated to find the optimum state with the lowest $\mathrm{LCOH}$. Moreover, three sub-cases representing three different economic settings were also calculated in comparison with the cost of the current steam based system, which is about \$12/MMBtu for heating and cooling. 


\subsubsection{Existing Heating and Cooling Basics}

West Virginia University has three main campuses, the Health Sciences campus, downtown campus and the Evansdale campus. The Health Sciences campus is equipped with its own heating system, including two $600 \mathrm{hp}$ Cleaver-Brooks boilers rated at 7.36 $\mathrm{MW}_{\text {th }}$ each. Downtown campus primarily uses steam directly through the buildings, while the proposed GDHC system uses a secondary water to exchange heat with the geothermal water and then to heat the buildings. It would not likely be economical to replace the steam system on downtown campus since all the buildings' heating utilities would be retrofitted. Hence, only the Evansdale campus was considered for this case study. Most buildings on this campus use a steam/water heat exchanger system. Saturated steam is delivered to each building and exchanges heat with water which circulating through the building's radiation system. As long as the steam pipelines allow a sufficient flow rate of geothermal water to deliver the necessary heat, it is reasonable to replace the steam by geothermal hot water without a significant facility change. As for cooling, there are two 300 ton dual stage steam absorption chillers and two 600 ton dual stage steam absorption chillers in Evansdale campus, providing cooling for a total space of $75,000 \mathrm{~m}^{2}$.

The university's steam master plan is consulted to define the pipeline network. The campus is served by a $200 \mathrm{~mm}$ ( 8 inch) high pressure pipeline from Morgantown Energy Associates. The main steam enters from the northeast of the campus and is reduced to $0.86 \mathrm{MPa}, 140^{\circ} \mathrm{C}$ saturated steam which is then distributed throughout the campus. The main steam line is a $250 \mathrm{~mm}$ (10 inch) pipeline with a pressure drop of $226 \mathrm{~Pa} / \mathrm{m}$. The size of the sub-stream line varies with the heating load of different building, usually ranging from $100 \mathrm{~mm}$ (4 inch) to $200 \mathrm{~mm}(8 \mathrm{inch})$.

\subsubsection{Proposed Heating and Cooling System}

The university steam master plan estimates each building's peak heating demand by categorizing the buildings into classroom, greenhouse, and library. The heating demand coefficient for each category is $158 \mathrm{~W} / \mathrm{m}^{2}$ for the classroom, $79 \mathrm{~W} / \mathrm{m}^{2}$ for the green house, and $63 \mathrm{~W} / \mathrm{m}^{2}$ for the library from the steam master plan. Peak cooling demand was 
estimated at $95 \mathrm{~W} / \mathrm{m}^{2}$ for all buildings from the steam master plan. Gross floor area of each building was consulted with the university facility office. Historical weather data in Morgantown area from the National Climatic Data Center database was used to curve-fit the monthly energy demand from the peak value, as shown in Equation 3.1, where $\dot{H}$ and $\dot{C}$ are heating and cooling demands, $i$ is month index, $H D D$ and $C D D$ are degree heating day and degree cooling days.

$$
\frac{\dot{H}_{i}}{\dot{H}_{\text {peak }}}=\frac{H D D_{i}}{H D D_{\text {peak }}} \text {, and } \frac{\dot{C}_{i}}{\dot{C}_{\text {peak }}}=\frac{C D D_{i}}{C D D_{\text {peak }}}
$$

Thermal energy delivered to surface $(\dot{Q})$ by a GDHC system was defined in Equation 3.2, where $\dot{m}_{R}$ is total mass flow rate $(\mathrm{kg} / \mathrm{s}), C_{\text {water }}$ is specific heat of water $\left(\mathrm{J} / \mathrm{kg} /{ }^{\circ} \mathrm{C}\right), T_{R}$ is production temperature which is assumed to be the same as production temperature $\left({ }^{\circ} \mathrm{C}\right)$, and $T_{r}$ is reinjection temperature $\left({ }^{\circ} \mathrm{C}\right)$.

$$
\dot{Q}=\dot{m}_{R} \times C_{\text {water }} \times\left(T_{R}-T_{r}\right)
$$

The delivered energy should be at least equal to the campus heating or cooling demand. With the constant geothermal gradient, the production temperature is positively linear to the drilling depth. The maximum flow rate per production well in this case study was assumed to be $50 \mathrm{~kg} / \mathrm{s}$. To provide a fixed amount of energy, the flow rate and the production temperature influences each other inversely based on Equation 3.2. Therefore, five pairs of flow rate and production temperature inputs were selected and modeled by Aspen Plus to find the lowest $\mathrm{LCOH}$ for the system.

The layout of the Evansdale campus buildings and pipeline was used to help build the Aspen Plus heating model, as shown in Figure 3.2. The heating model consists of the heat exchangers, the pipelines, and the stream splitting nodes. The geothermal water is not directly used to avoid potential corrosion and scaling inside the buildings' radiator systems. A secondary clean fluid is used to exchange heat with the geothermal water, and circulating through the building radiators. The stream fraction of each splitter was calculated based on the ratio of the downstream heating load to the main stream heat content. Overall heat loss coefficient $(U)$ of the pipeline was calculated at $0.1874 \mathrm{~W} /$ 
$\mathrm{m}^{2} \cdot{ }^{\circ} \mathrm{C}$, based on a polyurethane insulation cover. Pipeline pressure drop due to frictional losses was assumed to be $226 \mathrm{~Pa} / \mathrm{m}$. The length of the pipeline was estimated at $4.6 \mathrm{~km}$. No pressure drop was considered in the splitter. The system was designed to maintain the indoor temperature at $23.9^{\circ} \mathrm{C}$ in winter.

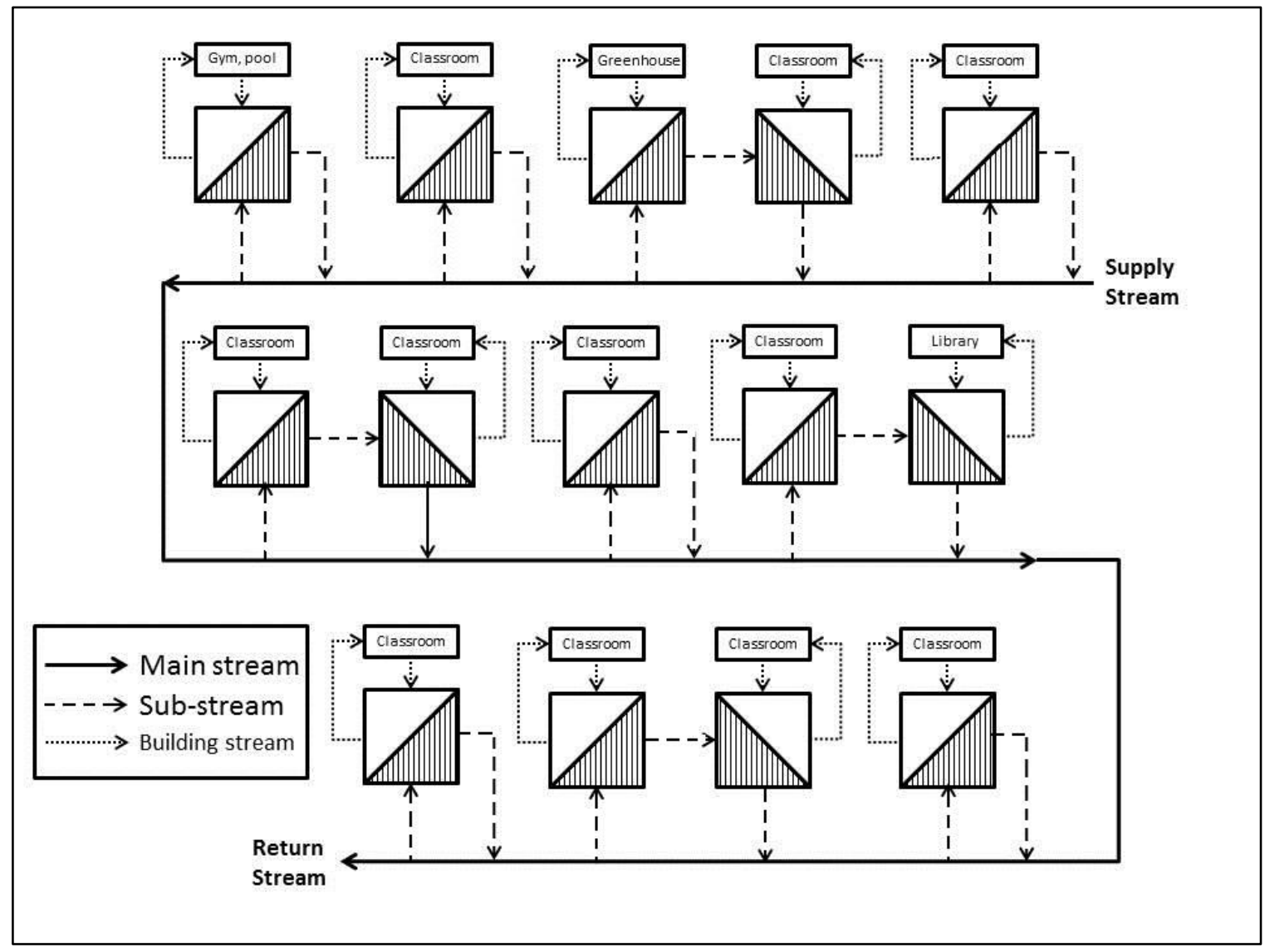

Figure 3.2: Layout of the Evansdale campus buildings (classroom, greenhouse, and library) and pipeline, based on which the Aspen Plus heating model was built.

Same centralized single-effect $\mathrm{H}_{2} \mathrm{O} / \mathrm{LiBr}$ absorption chiller system as discussed in Chapter 2 was assumed in this case study. The absorption chiller system was also modeled in the Aspen Plus to provide cooling for the campus. Simulations of the Aspen Plus heating and cooling model helped to determine the required production temperature and flow rate of the geothermal water, and to choose the candidate pairs of production temperature and flow rate for cost analysis. 


\subsubsection{LCOH Calculation for WVU Case Study}

To ensure comprehensiveness and accuracy, three other sub-cases were also solved for different economic environments. Case I estimated the LCOH for a general EGS based GDHC system. Case II considered certain tax preferential regulations and incentives for a renewable energy project. On the basis of Case II, Case III solved the LCOH exclude the surface facility operation and maintenance costs. It is because currently the university is purchasing steam from the steam company at \$12/MMBtu, which also does not account for the surface operation and maintenance costs. Thus, the LCOH calculated in Case III was used to compare with this steam cost.

A geothermal project is characterized with a high initial investment and a relatively low operating and maintenance cost (Erdogmus, et al., 2006). The initial investment includes the surface heating and cooling capital plus the geothermal well drilling cost. The operation and maintenance costs for both heating/cooling process and geothermal wells are needed every year throughout the lifetime. For this case study, a 5\% discount rate was assumed. Project lifetime was assumed to be 30 years.

The equipment cost of the heating/cooling system $C A P_{\text {surface }}$, is dominated by the cost of heat exchangers, which was estimated by the economic evaluation function of the Aspen Plus model. Estimation of drilling cost $C A P_{\text {drill }}$, followed the same as discussed in Chapter 2, as shown in Equation 3.3, where $d_{R}$ is the desired drilling depth. The equation was derived based on drilling data from the Joint Association Survey on Drilling Costs 2009 of the American Petroleum Institute. For each drilling interval, the overall cost was divided by the overall depth; then a unified polynomial function was used to fit all the data from all the drilling intervals.

$$
\begin{aligned}
\text { CAP } P_{\text {drill }}= & 1.1592-1.908 \times 10^{-14} \times d_{R}{ }^{4}+4.0292 \times 10^{-10} \times d_{R}{ }^{3} \\
& -2.5874 \times 10^{-6} \times d_{R}{ }^{2}+8.5065 \times 10^{-3} \times d_{R}
\end{aligned}
$$

The geothermal field O\&M cost $O M_{\text {well }}$ calculation used Sanyal's equation, which is derived from actual cost data from GeothermEx power generation facility, as shown in 
Equations 3.4 and 3.5 (Sanyal, 2004). The cost constant $c_{7}$, in cent $/ \mathrm{kWh}$, is a function of the power capacity $P$. $G_{s}$ is the annual providing thermal energy.

$$
\begin{aligned}
& c_{7}=2 \times \exp (-0.0025 \times(P / 0.1-5)) \\
& O M_{\text {well }}=c_{7} \times G_{s}
\end{aligned}
$$

The operating and maintenance cost of the heating/cooling system $O M_{\text {surface }}$, is associated with the day-to-day operation. The standard practice 18R-97 of the Association for the Advancement of Cost Engineering International (AACE) was used. Labor cost was assumed to be $\$ 100,000 / y e a r$. The utility cost of a GDHC system is mainly the pumping cost. The geothermal circulating water was assumed to be obtained from Monongahela River in close proximity to WVU with no cost. Equation 3.6 to 3.10 were used to estimate the annual pumping cost $P C$, where $\Delta P_{f}$ is the pressure drop due to the friction, $f$ is the friction coefficient, $\rho$ is water density, $v$ is the water flow velocity, $R e$ is the Reynolds number, $e$ is electricity rate, $\dot{V}$ is the volume flow rate, $m_{p}$ is the mass flow rate, $\eta_{\text {pump }}$ is the pump efficiency, and $t$ is the pumping time. The friction coefficient $f$ was calculated by Equation 3.7 for turbulent flow $\left(10^{4}>\operatorname{Re}>4 \times 10^{8}\right)$, where $\varepsilon$ is the average roughness for steel pipes, and was assumed to be $0.045 \mathrm{~mm}$ (Chen, 1979).

$$
\begin{gathered}
-\Delta P_{f}=\frac{2 \times f \times \rho \times v^{2} \times L}{D} \\
\frac{1}{\sqrt{4 f}}=-2 \times \log \left\{\frac{\varepsilon}{3.7065 D}-\frac{5.0452}{\operatorname{Re}} \log \left[\frac{1}{2.8257}\left(\frac{\varepsilon}{D}\right)^{1.1098}+\frac{5.8506}{\mathrm{Re}^{0.8981}}\right]\right\} \\
v=\frac{\dot{V}}{\pi D^{2} / 4} \\
\dot{V}=\dot{m}_{p} / \rho \\
P C_{\text {surface }}=\frac{e}{\eta_{\text {pump }}} \times\left(\Delta P_{f}\right) \times \dot{V} \times t
\end{gathered}
$$


The above terms are the major cost terms for the EGS based GDHC project. Estimation of $\mathrm{LCOH}$ followed the same procedure as discussed in Chapter 2, as shown in Equation 3.11 to 3.14 .

$$
\begin{gathered}
L C O H=\frac{\sum(C A P+O M+P C)}{\sum G_{S}} \\
\sum C A P=\left(C A P_{\text {surface }}+C A P_{\text {well }}\right) \\
\sum(O M+P C)=\left(O M_{\text {surface }}+O M_{\text {well }}+P C_{\text {surface }}+P C_{\text {well }}\right) \times \frac{(1+r)^{30}-1}{r \times(1+r)^{30}} \\
\sum G_{S}=G_{S} \times \frac{(1+r)^{30}-1}{r \times(1+r)^{30}}
\end{gathered}
$$

\subsection{Empirical LCOH Function Derivation}

From LCOH analysis of hydrothermal resources and near hydrothermal EGS in Chapter 2, it was concluded that energy demand has the most negative effect while the drilling cost has the most positive effect on $\mathrm{LCOH}$. To further look into the mathematical relations between them, two basic GDHC system metrics were selected as LCOH function variables, which are population density and geothermal gradient. WVU cost model was used to find the function by simply changing one variable while keeping the other constant.

The following part discusses several modifications of the WVU cost model for a more general LCOH estimation. The WVU case study directly estimated the energy demand by a building heating and cooling demand intensity constant, while here the energy demand was estimated based on population density, as shown in Equation 3.15, where $P$ is the population density, $A$ is the targeted area, $h p$ is average household size, and $\delta_{h}$ is household heating intensity. $P$ is the census tract based population density in $\mathrm{ppl} / \mathrm{km}^{2}$, which is available from the U.S. Census Bureau. $A$ was assumed to be $2.56 \mathrm{~km}^{2}$ which is consistent with the surface design in Chapter 2. $h p$ in ppl/house and $\delta_{h}$ in $\mathrm{MW}_{\mathrm{th}} /$ house are state wide constant available from the U.S. Energy Information Administration. 


$$
\dot{H}=\frac{P \times A}{h p} \times \delta_{h}
$$

The WVU cost model did not include the surface distribution cost, while here estimation of the distribution network cost was needed, and followed the same procedure as discussed in Chapter 2. The WVU cost model assumed the system return temperature to be $40^{\circ} \mathrm{C}$, while here the return temperature was set as s variable. The cost model solved the minimum LCOH by varying the drilling depth, and was achieved by the Excel solver function.

The geothermal gradient was calculated by least square error fitting with the SMU geothermal temperature at depth data, with surface temperature assumed to be $10^{\circ} \mathrm{C}$, as shown in Equation 3.16, where $G$ is the geothermal gradient, $i$ is depth from $3.5 \mathrm{~km}$ to 9.5 $\mathrm{km}$, with a $1 \mathrm{~km}$ interval, and $T_{R i}$ is geothermal temperature at depth $i$. Then a series of geothermal gradients were selected based on the gradient calculation results for WV. The $\mathrm{LCOH}$ function as an equation of population density at constant geothermal gradient was assumed similar to what have been found from the results of the hydrothermal resources in Chapter 2, as shown in Equation 3.17, where $a, b$, and $n$ are constants. For each gradient, different population densities were input into the cost model to calculate the LCOH. Constants $a, b$, and $n$ were calculated by least square error fitting Equation 3.18 with the population density and LCOH data. Finally, LCOH for an EGS based GDHC system for each of the census tract in WV was estimated.

$$
\begin{aligned}
& \text { MINIMUM: } \sum_{3.5}^{9.5}\left(i \times G+10-T_{R i}\right)^{2} \\
& L C O H=a \times P^{n}+b
\end{aligned}
$$

\subsection{Results and Discussion}

\subsubsection{West Virginia Geothermal Maps}

The geothermal temperature maps were generated by working with SMU Geothermal Lab. Figure 3.3 shows the geothermal temperature map of WV at $4.5 \mathrm{~km}$. Other 
geothermal temperature maps of WV can be found in Appendix B. SMU Geothermal Lab updated the temperature data from oil and gas wells, whose locations are also shown in Figure 3.3. To interpolate geothermal temperatures at other locations, the inverse distance weighted method was used and achieved by ArcGIS, which assumed the temperatures for the locations that are close to one another are more alike than those that are farther apart. Such an algorithm gives a more accurate estimation if the sample data is densely located. At $4.5 \mathrm{~km}$, geothermal temperature in Morgantown is in the range of 130 to $150^{\circ} \mathrm{C}$. The geothermal gradient at WVU was calculated to be $26.5^{\circ} \mathrm{C} / \mathrm{km}$.

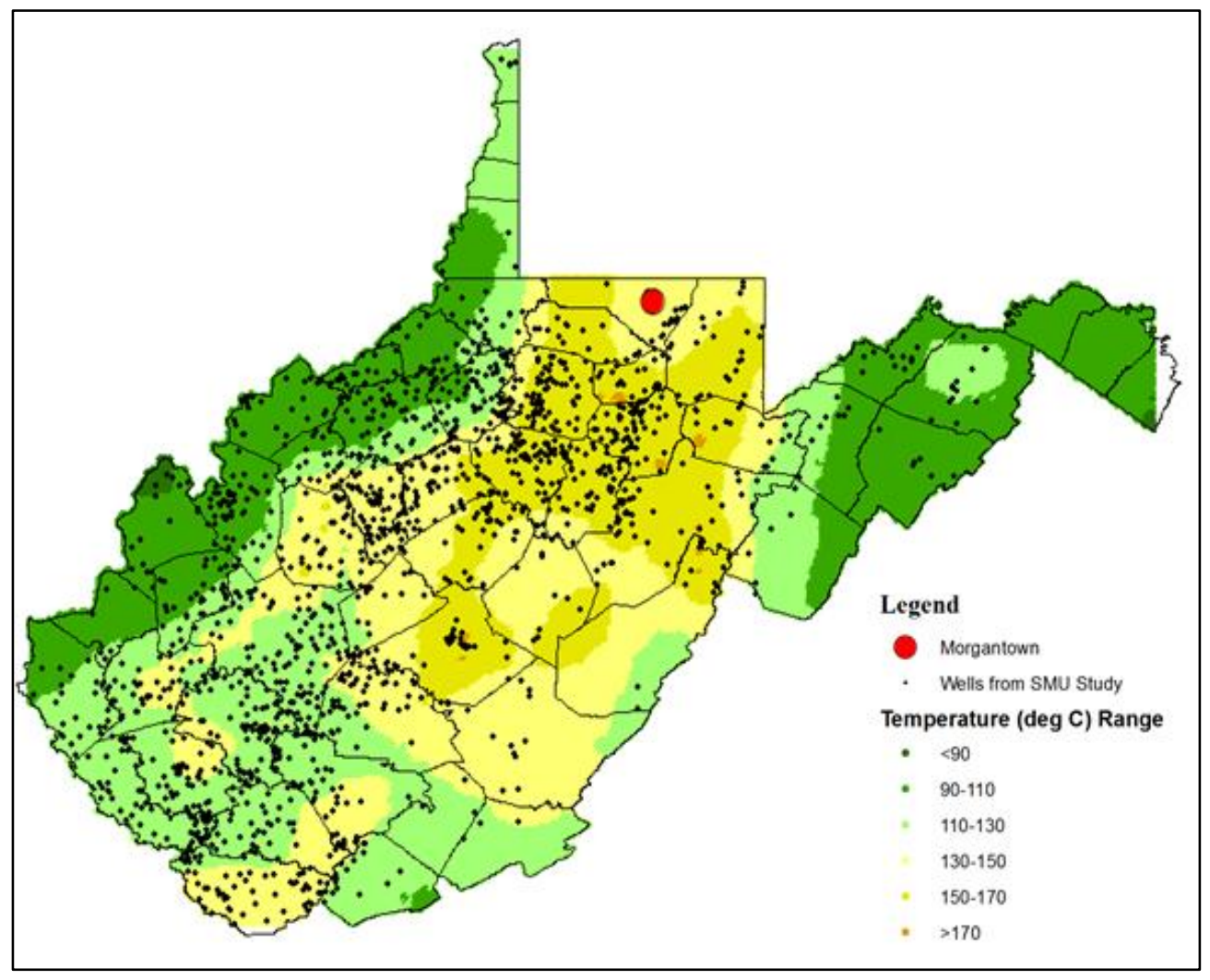

Figure 3.3: Geothermal temperature map of West Virginia at $4.5 \mathrm{~km}$, black dots show the locations of oil and gas wells from which SMU updated their temperature profiles. 


\subsubsection{Campus GDHC Characterization}

With the steam master plan, the campus peak heating and cooling demand were estimated at $22.9 \mathrm{MW}_{\text {th }}$ and $8.6 \mathrm{MW}_{\text {th }}$, respectively. Annual energy consumption was estimated at 305,184 MMBtu. The monthly heating and cooling demand were also estimated, as shown in Figure 3.4. Peak heating demand was estimated in January, while peak cooling demand was estimated in July.

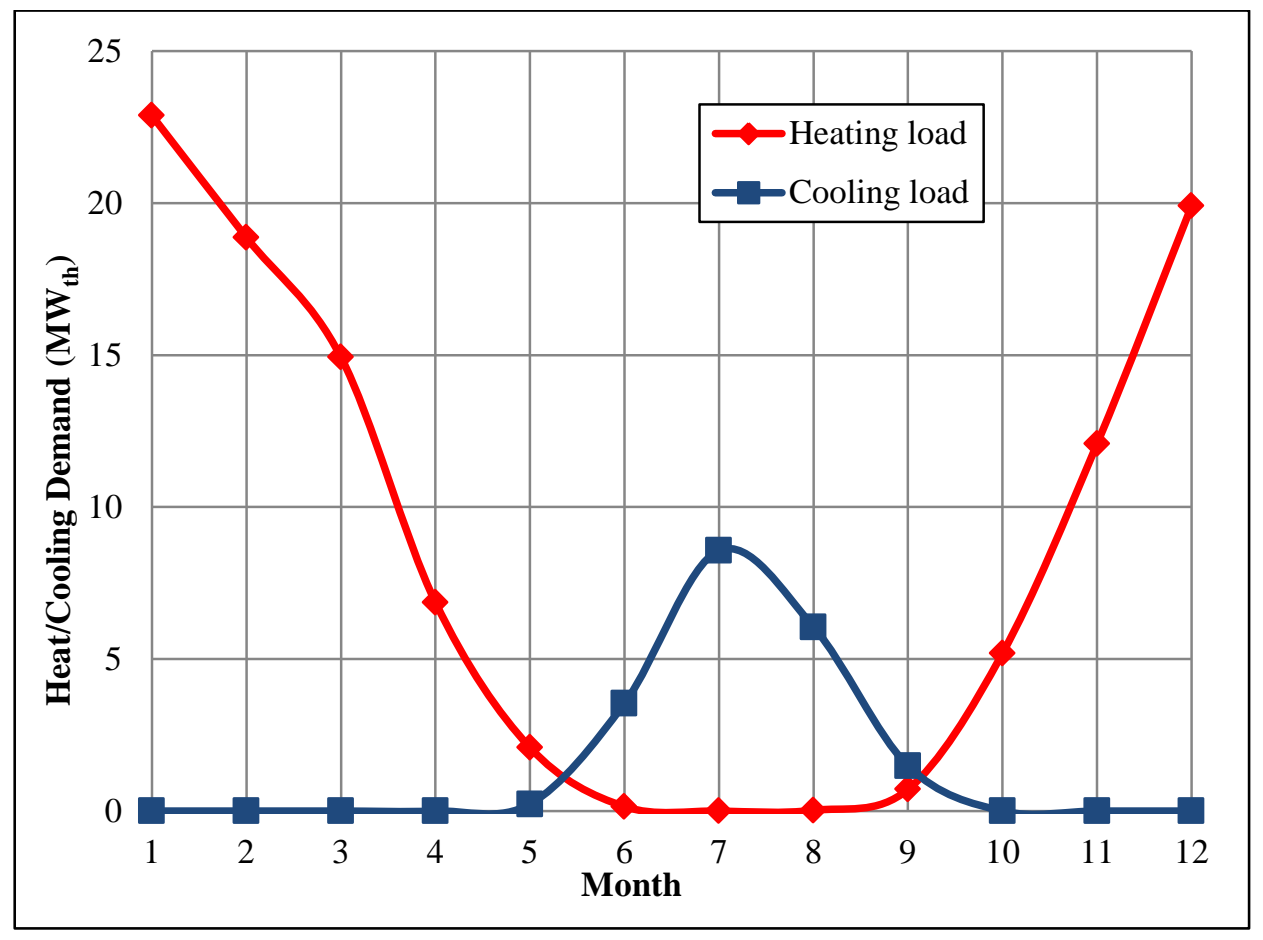

Figure 3.4: Monthly heating and cooling demand of the Evansdale Campus, WVU.

The GDHC system is designed to maintain the indoor temperature during winter at $23.9^{\circ} \mathrm{C}\left(75^{\circ} \mathrm{F}\right)$. As discussed in Chapter 2, geothermal hot water provides heating by a pair of heat exchangers. By assuming the overall pinch temperature of the two exchangers to be $16^{\circ} \mathrm{C}$, the minimum return temperature was calculated to be $40^{\circ} \mathrm{C}$ $\left(104^{\circ} \mathrm{F}\right)$. Considering the geothermal gradient at $26.5^{\circ} \mathrm{C} / \mathrm{km}$, four geothermal production temperatures were selected and simulated to ensure the drilling depth is less than $5 \mathrm{~km}$, which are $80^{\circ} \mathrm{C}, 100^{\circ} \mathrm{C}, 120^{\circ} \mathrm{C}$, and $140^{\circ} \mathrm{C}$. A production temperature higher or lower than this range would result in either a prohibitively expensive drilling cost or an 
unreasonably large number of production wells. Figure 3.5 shows the required flow rate versus the geothermal return temperature at different geothermal supply temperatures calculated by the Aspen Plus heating model, which agrees with Equation 3.2 that to provide a fixed amount of heating, geothermal mass flow rate and temperature drops between supply and return temperature affects each other inversely.

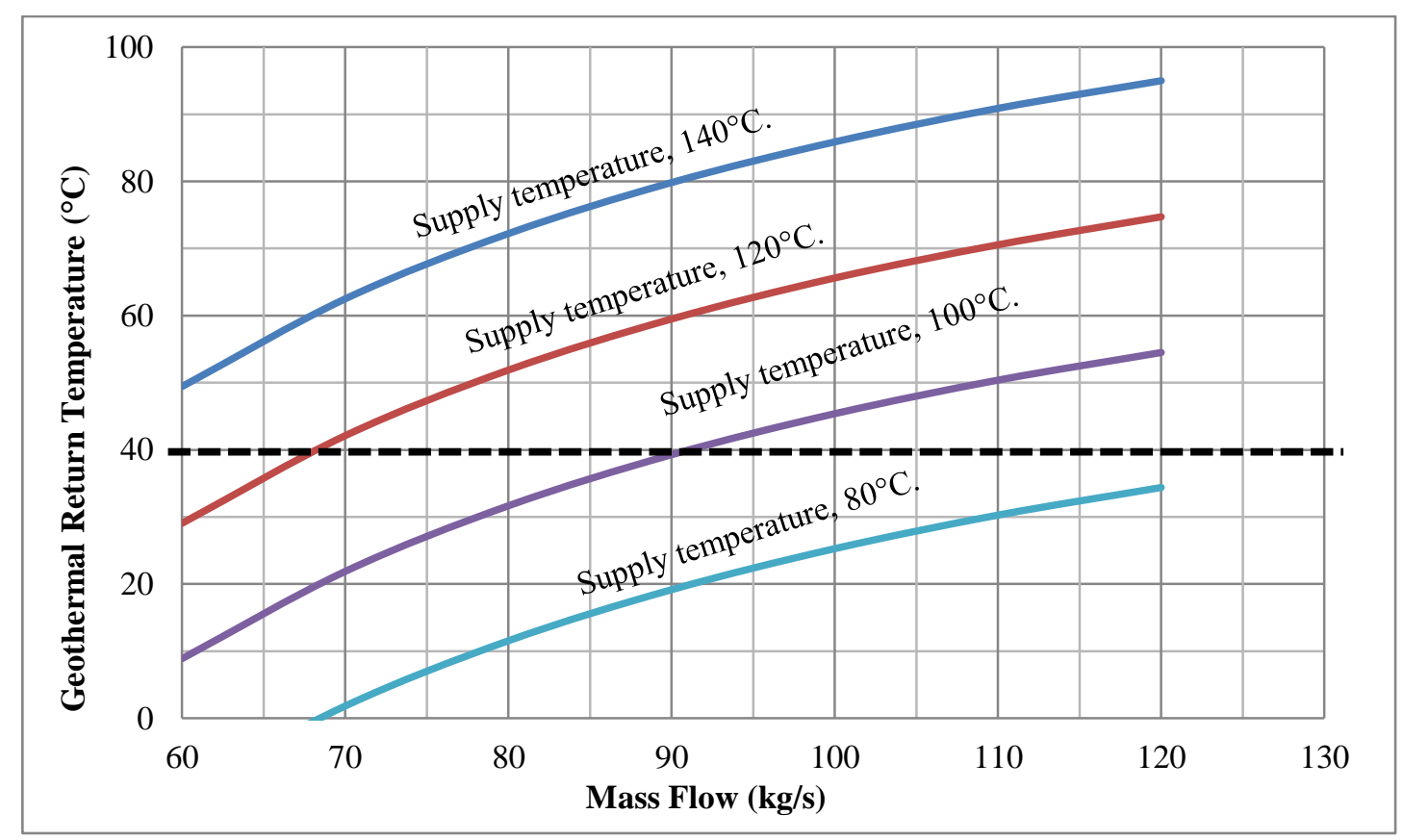

Figure 3. 5: Return temperature versus mass flow rate at selected supply temperatures to provide campus peak heating demand, dashed line indicates the minimum requirement for the return temperature.

By assuming the minimum return temperature as $40^{\circ} \mathrm{C}$, Figure 3.5 also reveals the required flow rate at each supply temperature so that the minimum return temperature is maintained. The Aspen Plus Design Spec function was used to find each minimum flow rate (variable) at each supply temperature (condition), to achieve a $40^{\circ} \mathrm{C}$ return temperature (target). Results are shown in Figure 3.6. The curve divides the plot into two parts. To provide $22.9 \mathrm{MW}_{\text {th }}$ of heating, flow rate must be selected from the section above the curve at each supply temperature to ensure a normal operation of the heat exchangers. Given practical constrains on the flow rate that can be achieved for a production well, maximum flow rate per well was assumed to be $50 \mathrm{~kg} / \mathrm{s}$, as plotted by 
the dashed lines in Figure 3.6. Once above the dashed line, one additional production well should be drilled. The Aspen Plus Design Spec function was again used to find the supply temperature at $148.9^{\circ} \mathrm{C}$ when the flow rate is $50 \mathrm{~kg} / \mathrm{s}$, and the supply temperature at $95.6^{\circ} \mathrm{C}$ when the flow rate is $100 \mathrm{~kg} / \mathrm{s}$. Therefore, five pairs of supply temperature and flow rate were selected for cost estimation, as shown in Table 3.2.

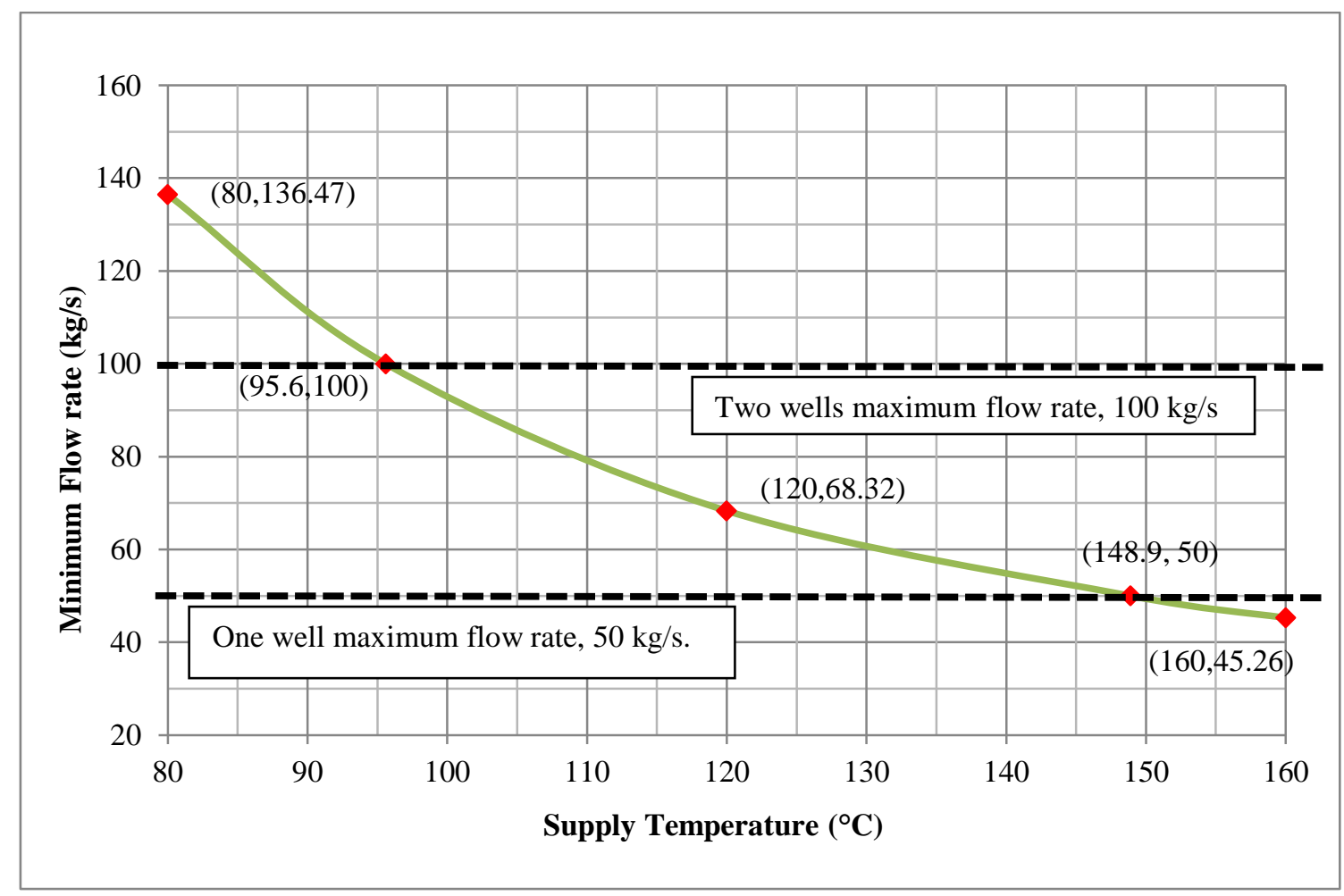

Figure 3.6: Minimum mass flow rate versus supply temperature to supply campus heating demand. Dashed lines indicate one production and two production wells' maximum flow rate. Red dots indicate the selected pairs of temperature and flow rate for cost estimation.

Since the campus heating demand is much higher than the cooling demand, any selected pair of supply temperature and flow rate from the heating model is able to provide sufficient cooling for the campus. Table 3.2 shows the five cases of supply temperature and mass flow rate which were investigated for WVU case study. 
Table 3.2: Investigated cases of geothermal flow and temperature for WVU case study.

\begin{tabular}{|c|c|c|}
\hline Index & Temperature, ${ }^{\circ} \mathrm{C}$ & Flow Rate, $\mathrm{kg} / \mathrm{s}$ \\
\hline 1 & 160.0 & 45.26 \\
\hline 2 & 148.9 & 50.00 \\
\hline 3 & 120.0 & 68.32 \\
\hline 4 & 95.6 & 100.00 \\
\hline 5 & 80.0 & 136.47 \\
\hline
\end{tabular}

\subsubsection{Campus GDHC Cost Analysis}

With geothermal gradient at $26.5^{\circ} \mathrm{C} / \mathrm{km}$ and surface temperature at $10^{\circ} \mathrm{C}$, drilling depths for case 1, 2, 3, 4, and 5 were calculated to be $5.67 \mathrm{~km}, 5.25 \mathrm{~km}, 4.16 \mathrm{~km}, 3.23 \mathrm{~km}$, and $2.65 \mathrm{~km}$, respectively. With the maximum flow rate of one production well at $50 \mathrm{~kg} / \mathrm{s}$, the number of wells including injection and production were calculated to be 2, 2, 3, 3, and 4 for each case. Overall drilling costs were calculated to be $\$ 39.92,36.67,45.21,39.48$, and 48.35 million, respectively. The O\&M cost of the reservoir field was estimated at $\$ 1.79$ million per year for all the five cases.

The Aspen Plus economic model directly evaluated the equipment purchase cost for the heating and cooling system, which is \$ 0.2 and 0.69 million. The AACE recommended practice 16R-90 estimated another \$ 2.34 million for installation, handling, and other indirect cost such as general facilities and overhead. Thus the total surface capital was estimated at $\$ 3.23$ million. Annual pumping costs were estimated to $\$ 21,467, \$ 23,715$, $\$ 32,405, \$ 47,431$, and $\$ 64,729$ for case 1, 2, 3, 4, and 5, respectively. Table 3.3 shows the surface O\&M cost breakdown by taking case 2 as an example. Surface O\&M costs for five cases were estimated to be $\$ 1.02,1.02,1.03,1.05$, and 1.06 million per year, respectively. Cost summary for all cases are shown in Table 3.4. On average, well capital accounts for $47.3 \%$ of the total investment, surface capital accounts for $3.7 \%$, well field O\&M accounts for $31.0 \%$, and surface O\&M accounts for $18.0 \%$. So choosing a high temperature geothermal reservoir with a sufficient permeability is the most important factor for an economical GDHC project. 
Table 3.3: Surface operation and maintenance cost estimation for case 2, in \$/per year, except for total direct cost, which is in $\$$.

\begin{tabular}{|c|c|c|}
\hline Item & Calculation & Value \\
\hline Total Direct Cost & $T D C$ & $3,226,212$ \\
\hline \hline Utility cost & $U C$ & 23,715 \\
\hline Labor cost & $C_{\text {labor }}$ & 100,000 \\
\hline Supervisory & $C_{\text {super }}=0.18 \times C_{\text {labor }}$ & 18,000 \\
\hline Maintenance & $M C=0.06 \times T D C$ & 193,573 \\
\hline Operation supply & $C_{\text {supply }}=0.009 \times T D C$ & 29,036 \\
\hline Depreciation & $D C=0.1 \times T D C$ & 322,621 \\
\hline Tax and insurance & $T I=0.032 \times T D C$ & 103,239 \\
\hline Overhead & $O V=0.708 \times C_{\text {labor }}+0.036 \times T D C$ & 186,944 \\
\hline Administration & $A D=0.177 \times C_{\text {labor }}+0.009 \times T D C$ & 46,736 \\
\hline Operation and Maintenance & $\begin{array}{c}\mathrm{O} \& \mathrm{M}=U C+C_{\text {labor }}+C_{\text {super }}+M C \\
+C_{\text {supply }}+D C+T I+O V+A D\end{array}$ & $1,023,864$ \\
\hline
\end{tabular}

Table 3.4: Cost summary of the proposed GDHC system on WVU campus, based on five selected temperature and flow rate cases.

\begin{tabular}{|c|c|c|c|c|c|}
\hline & 1 & 2 & 3 & 4 & 5 \\
\hline $\begin{array}{c}\text { Wells capital } \\
\times 10^{6} \$\end{array}$ & 39.92 & 36.67 & 45.21 & 39.48 & 48.35 \\
\hline $\begin{array}{c}\text { Wells O\&M, } \\
\times 10^{6} \text { \$/year }\end{array}$ & \multicolumn{5}{|c|}{1.79} \\
\hline $\begin{array}{c}\text { Surface capital, } \\
\times 10^{6} \$\end{array}$ \\
\hline $\begin{array}{c}\text { Surface O\&M, } \\
\times 10^{6} \text { \$/year }\end{array}$ & 1.02 & 1.02 & 1.03 & 1.05 & 1.06 \\
\hline
\end{tabular}


Finally, the LCOH for the proposed EGS based GDHC system on WVU campus was calculated with different production temperatures and flow rate, and in different economic scenarios. The results summary is shown in Table 3.5.

Table 3.5: LCOH (\$MMBtu) for the WVU campus GDHC system, in different geothermal water characteristics (case 1,2, 3, 4, and 5) and different economic scenarios (case I, II, and III)

\begin{tabular}{|c|c|c|c|c|c|}
\hline & 1 & 2 & 3 & 4 & 5 \\
\hline I & 18.37 & 17.69 & 19.54 & 18.37 & 20.31 \\
\hline II & 16.98 & 16.29 & 18.14 & 16.97 & 18.92 \\
\hline III & 15.03 & 14.33 & 16.15 & 14.93 & 16.82 \\
\hline
\end{tabular}

With certain preferential regulations and incentives, and by not considering the surface $\mathrm{O} \& \mathrm{M}$ cost, $\mathrm{LCOH}$ in economic case III is lower than that in other cases. Among the five candidate pairs of production temperature and flow rate, case 2 has the lowest $\mathrm{LCOH}$. Figure 3.7 shows the calculated $\mathrm{LCOH}$ for five temperature and flow rate cases in economic Case III. Figure 3.7 shows that although a larger mass flow rate can efficiently offset the temperature decrease and hence decrease drilling cost, it may also require more production wells to be drilled. For WVU case study, one injection well and one production well with a $148.9^{\circ} \mathrm{C}$ production temperature and a $50 \mathrm{~kg} / \mathrm{s}$ flow rate provides the most economical geothermal energy. 


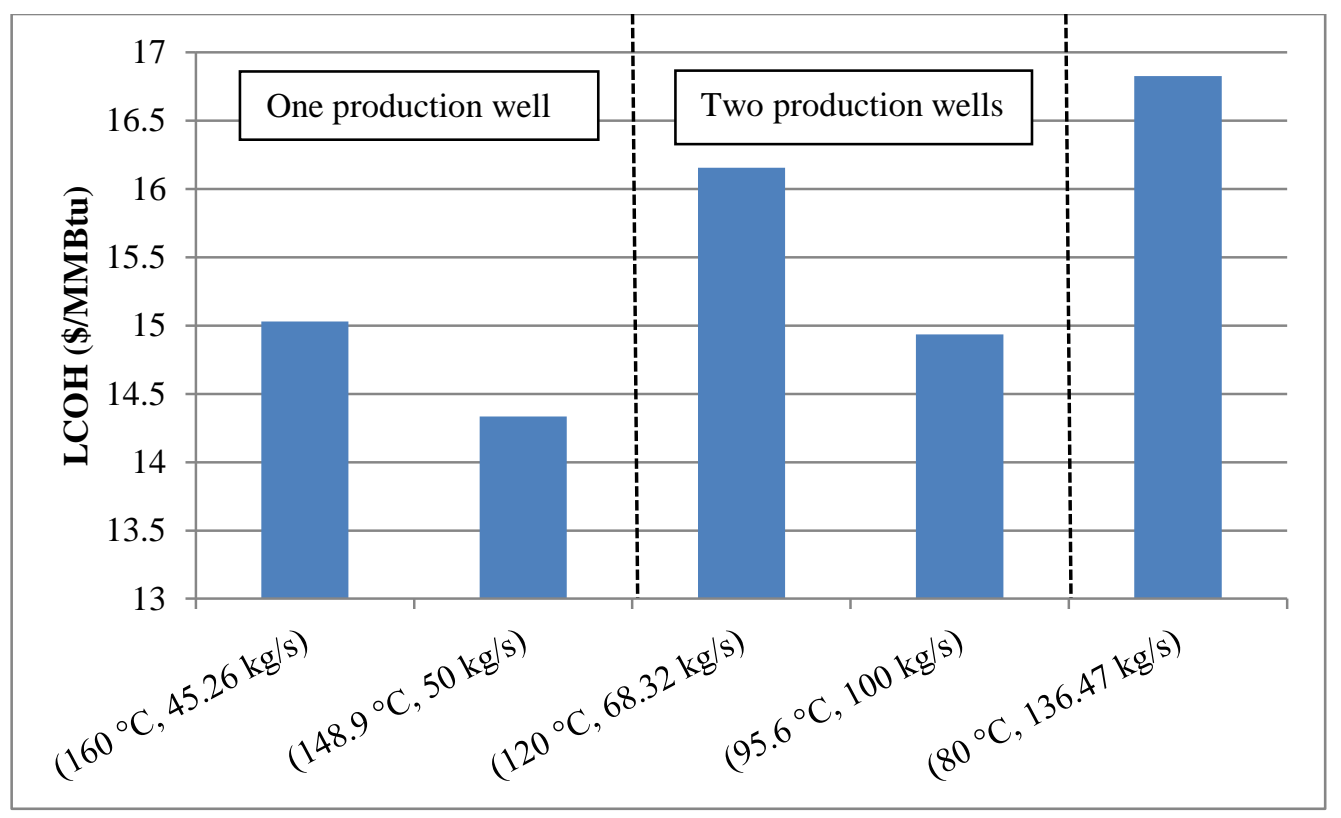

Figure 3.7: $\mathrm{LCOH}$ for the WVU GDHC project with selected temperature and flow rate.

Thus, for technical and economic consideration, the geothermal district heating and cooling system in West Virginia University should use one production and one injection well with a depth of $5.25 \mathrm{~km}$ for $148.9^{\circ} \mathrm{C}$ geothermal temperature. Maximum flow rate should be maintained at peak heating. The levelized cost of heating is estimated as \$14.33/MMBtu, which is higher than cost of the current steam based heating and cooling system at \$12/MMBtu. To further decease the $\mathrm{LCOH}$, cascading applications to decrease the return temperature should be considered, such as geothermal based green house, or using geothermal heating for snow melting under pathways and for the tracks of the university personal rapid transition (PRT) system. In addition, increasing maximum flow rate of the production well is also recommended with improved well field technology in the near future. If a lower return temperature can be achieved at $30^{\circ} \mathrm{C}$, and the maximum flow rate can be achieved at $65 \mathrm{~kg} / \mathrm{s}, \mathrm{LCOH}$ for the WVU GDHC system can be as low as \$13.61/MMBtu.

\subsubsection{LCOH Functions and State Wide Estimation}

The geothermal gradient and the population density maps of WV were drawn by ArcGIS, as shown in Figures 3.8 and 3.9. 


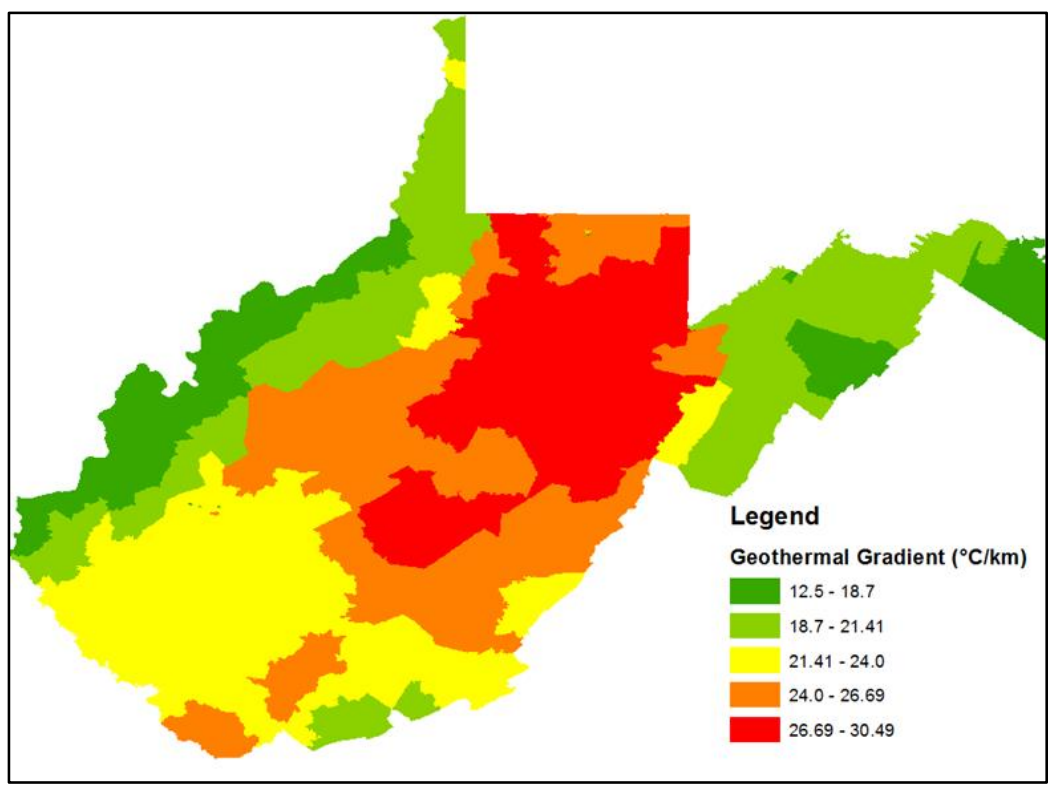

Figure 3. 8: Geothermal gradient map of WV, with a warmer color indicating a higher geothermal gradient.

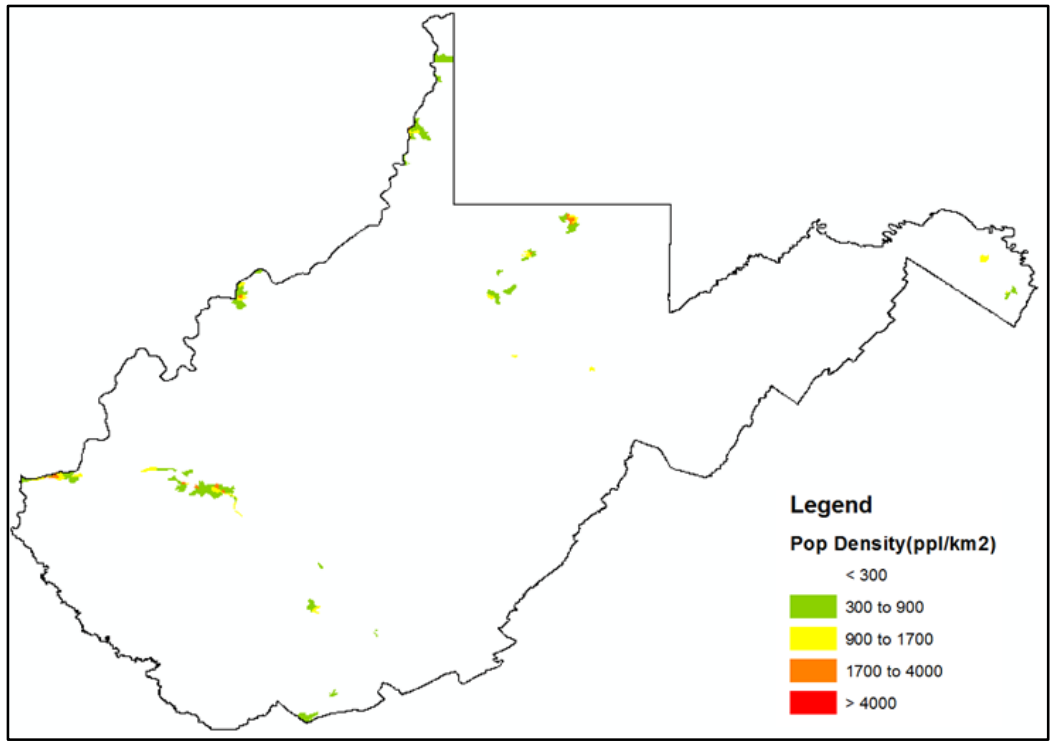

Figure 3.9: Population density map of WV, with a warmer color indicating a higher population density.

WV geothermal gradient was estimated in the range of 12 to $30^{\circ} \mathrm{C} / \mathrm{km}$. For $\mathrm{LCOH}$ functions derivation, geothermal gradients were set at 14 to $30^{\circ} \mathrm{C} / \mathrm{km}$, with $1^{\circ} \mathrm{C} / \mathrm{km}$ interval. For each gradient, the population densities were input to the cost model from 
1,000 to $30,000 \mathrm{ppl} / \mathrm{km}^{2}$, and the $\mathrm{LCOH}$ results were recorded. The population density and $\mathrm{LCOH}$ results were fitted with Equation 3.18 by least square error analysis, to find the function constants $\mathrm{a}, \mathrm{b}$, and $\mathrm{n}$. Results of $\mathrm{a}, \mathrm{b}$, and $\mathrm{n}$ for different geothermal gradients are shown in Table 3.6.

Table 3.6: Least square fitting results of $\mathrm{LCOH}$ function constants $\mathrm{a}, \mathrm{b}$, and $\mathrm{n}$ for different geothermal gradients $(G)$.

\begin{tabular}{|c|c|c|c|c|c|c|c|}
\hline$G,{ }^{\circ} \mathrm{C} / \mathrm{km}$ & $\mathrm{a}$ & $\mathrm{b}$ & $\mathrm{n}$ & $G,{ }^{\circ} \mathrm{C} / \mathrm{km}$ & $\mathrm{a}$ & $\mathrm{b}$ & $\mathrm{n}$ \\
\hline 14 & 22479.62 & 20 & -0.97166 & 23 & 7270.58 & 12 & -0.81079 \\
\hline 15 & 14552.61 & 18 & -0.90838 & 24 & 7932.52 & 12 & -0.82534 \\
\hline 16 & 14413.62 & 17 & -0.90936 & 25 & 8533.13 & 12 & -0.83772 \\
\hline 17 & 13187.28 & 16 & -0.89739 & 26 & 9269.50 & 12 & -0.8549 \\
\hline 18 & 19070.67 & 16 & -0.95537 & 27 & 9952.80 & 12 & -0.8708 \\
\hline 19 & 15327.95 & 15 & -0.92264 & 28 & 10636.10 & 12 & -0.8867 \\
\hline 20 & 39487.57 & 13 & -1.05939 & 29 & 11319.40 & 12 & -0.9026 \\
\hline 21 & 5803.75 & 12 & -0.77378 & 30 & 12002.70 & 12 & -0.9185 \\
\hline 22 & 6558.26 & 12 & -0.79376 & & & & \\
\hline
\end{tabular}

There are 484 census tracts in West Virginia. Table 3.7 lists the 23 census tracts with the estimated LCOH below \$30/MMBtu. GEOIDs are numeric codes that uniquely identify all administrative/legal and statistical geographic areas by the U.S. Census Bureau. Among all the census tracts in WV, the one (with GEOID 54061010101) in Morgantown has the lowest LCOH. Potential places are concentrated in Monongalia county, Kanawha county, and Cabell county. Figure 3.10 shows the census tracts map of WV with their calculated $\mathrm{LCOH}$, in which a warmer color represents a lower LCOH. It is clear that the warm colored areas in Figure 3.10 is very much overlapped with the populated areas as shown in Figure 3.9, indicating that a populated area is essential to an economical GDHC project. 
Table 3.7: Potential places for GDHC systems development in WV, whose LCOH is less than $\$ 30 /$ MMBtu.

\begin{tabular}{|c|c|c|c|c|c|}
\hline GEOID & LCOH & County & GEOID & LCOH & County \\
\hline 54061010101 & 15.44204 & Monongalia & 54039000800 & 27.26394 & Kanawha \\
\hline 54061010202 & 20.95987 & Monongalia & 54061010201 & 27.32543 & Monongalia \\
\hline 54039001300 & 22.69788 & Kanawha & 54039000600 & 27.74855 & Kanawha \\
\hline 54061010102 & 23.76512 & Monongalia & 54039001200 & 27.97992 & Kanawha \\
\hline 54069000500 & 24.71884 & Ohio & 54061012000 & 28.28341 & Monongalia \\
\hline 54049020100 & 25.64488 & Marion & 54011001100 & 28.91448 & Cabell \\
\hline 54039010200 & 25.88468 & Kanawha & 54039000700 & 28.94942 & Kanawha \\
\hline 54061010901 & 26.04718 & Monongalia & 54011001300 & 29.17957 & Cabell \\
\hline 54039013500 & 26.32721 & Kanawha & 54097966700 & 29.38451 & Upshur \\
\hline 54011001400 & 26.69390 & Cabell & 54107000500 & 29.67028 & Wood \\
\hline 54011000500 & 26.87133 & Cabell & 54107000300 & 29.70306 & Wood \\
\hline 54011001200 & 26.96996 & Cabell & & & \\
\hline
\end{tabular}




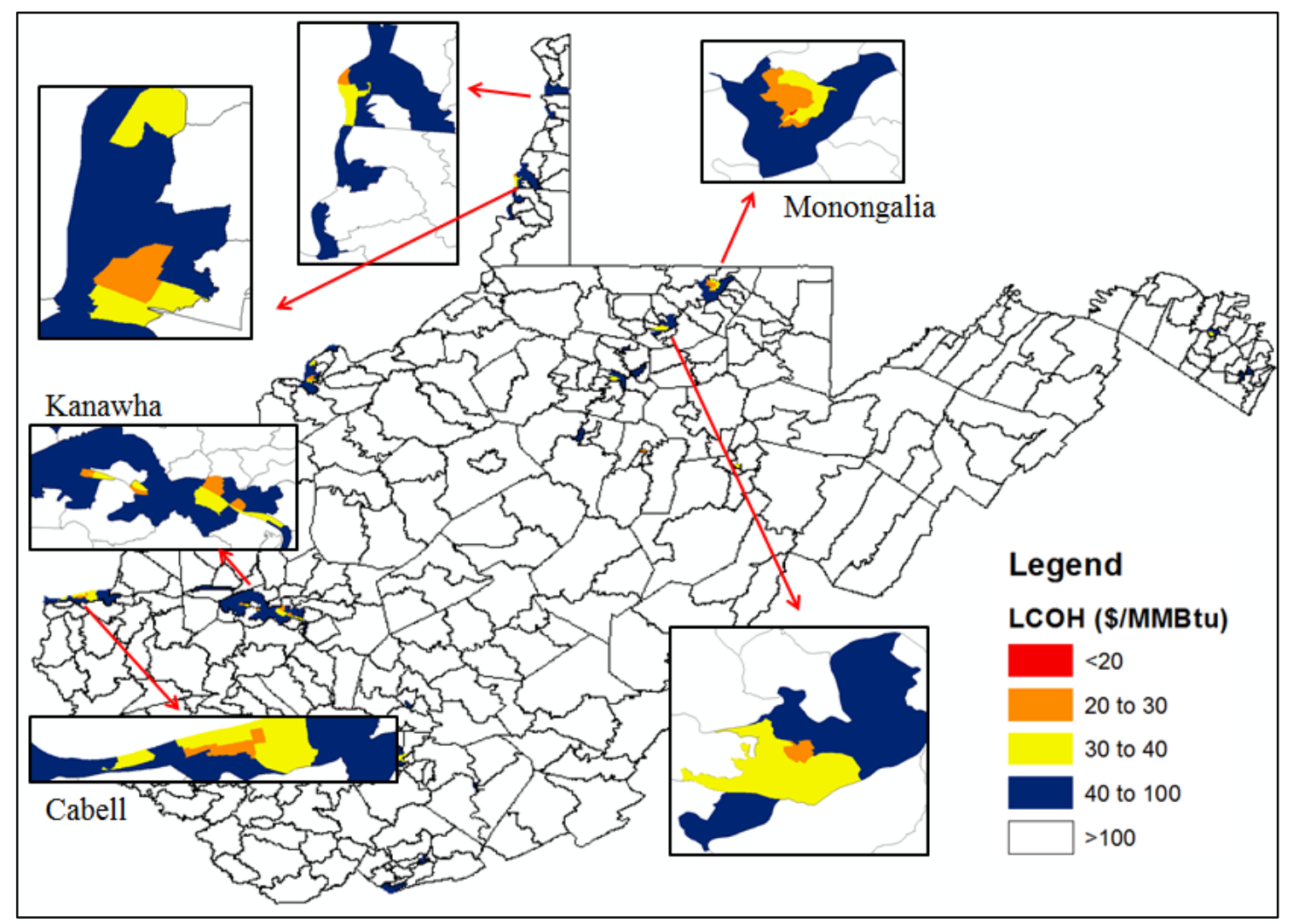

Figure 3.10: Census tracts map of WV, coupled with their estimated $\mathrm{LCOH}$, with a warmer color representing a lower LCOH. Lowest LCOH is found at Morgantown, WV.

Finally, the $\mathrm{LCOH}$ functions were plotted by Matlab for gradients from 10 to $50^{\circ} \mathrm{C} / \mathrm{km}$ and for population densities up to $30,000 \mathrm{ppl} / \mathrm{km}^{2}$, as shown in Figure 3.11. The LCOH decreases with increase in geothermal gradient and population density. The population density shows a strong negative effect on $\mathrm{LCOH}$ at any geothermal gradient, while the gradient only shows a negative effect on $\mathrm{LCOH}$ at a low population density. 


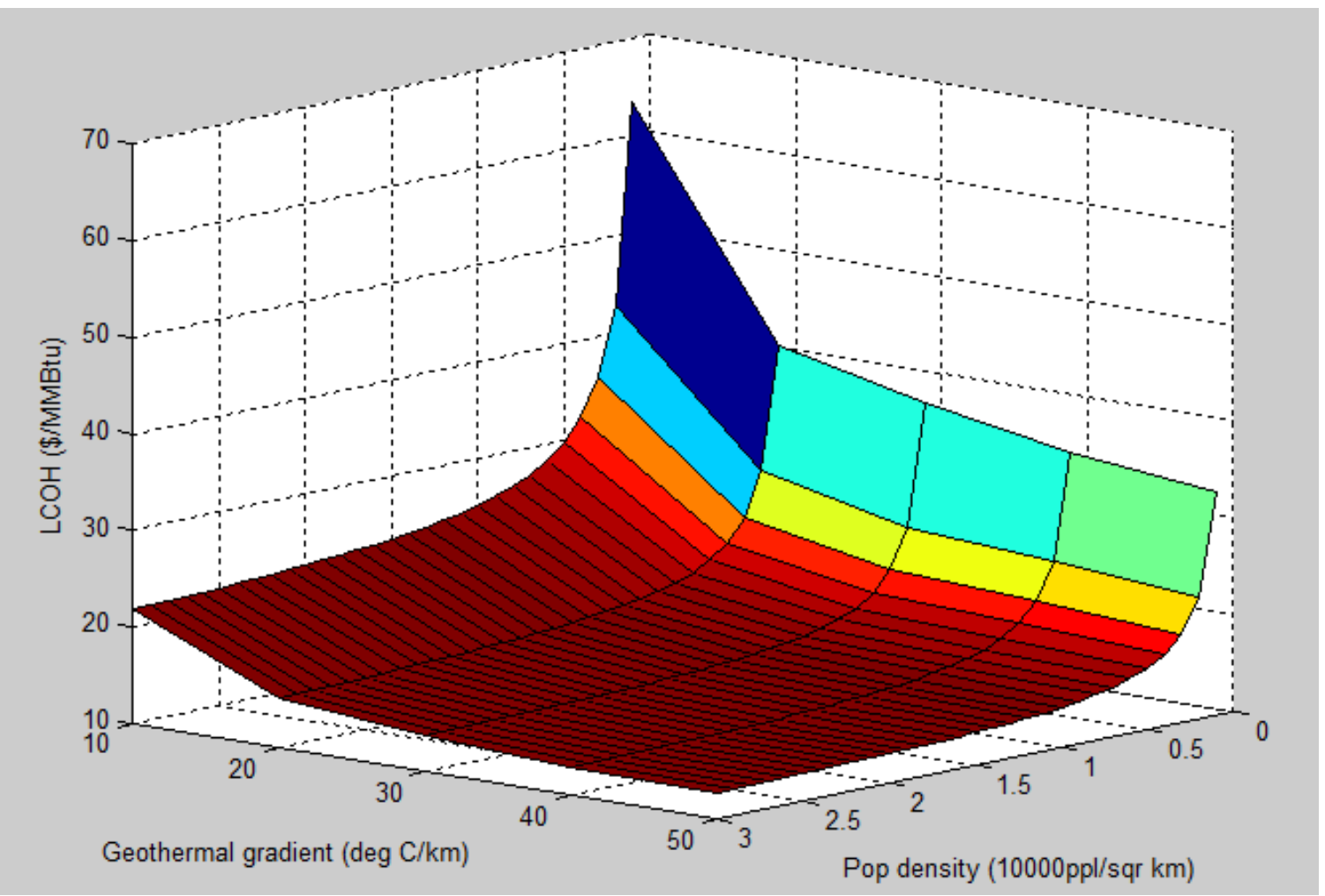

Figure 3.11: Plot showing the variation of $\mathrm{LCOH}$ function with population density and geothermal gradient.

\subsection{Conclusion}

This part of the study first conducted a techno-economic evaluation of an EGS based geothermal district heating and cooling system in the Evansdale campus, West Virginia University. The geological conditions at WVU and also reports from the SMU Geothermal Lab stating elevated geothermal temperatures in WV, fortify the fact that WVU has the potential to develop a GDHC system technically. Hence, the use of a geothermal system as a substitute to the current steam system particularly for heating and cooling has been the primary objective of this part of the study. To achieve the proposed objective, an Aspen Plus heating and cooling model was designed and simulated to provide the campus heating and cooling demand at 22.9 $\mathrm{MW}_{\text {th }}$ and 8.6 $\mathrm{MW}_{\text {th. }}$ To optimize the levelized cost of energy, five pairs of temperature and flow rate of geothermal production water were investigated. For the WVU case, a doublet system with a $50 \mathrm{~kg} / \mathrm{s}$ flow rate was calculated to be more economical than a triplet (with two production well, 
at a flow rate of $100 \mathrm{~kg} / \mathrm{s}$ ) or a higher order geothermal system. Geothermal wells were calculated to be drilled to a depth of $5.25 \mathrm{~km}$ to ensure a geothermal temperature at $148.9^{\circ} \mathrm{C}$. Maximum production flow rate at $50 \mathrm{~kg} / \mathrm{s}$ was recommended to ensure lowest LCOH. On Average, well capital accounts for $47.3 \%$ of the total investment, surface capital accounts for $3.7 \%$, well O\&M accounts for 31.0\%, and surface O\&M accounts for $18.0 \%$. Well capital and O\&M costs constitute the major portion of the overall investment. Drilling at a shallower depth might decrease the drilling cost significantly. However, it may require more production wells to ensure sufficient energy production. With certain tax preferential regulations and incentives, the LCOH for the WVU case was calculated at \$16.29/MMBtu. In comparison with the current steam purchase price which is $\$ 12 / \mathrm{MMBtu}$, surface O\&M cost was excluded. The resulting $\mathrm{LCOH}$ was then calculated at \$14.33/MMBtu. To further decease the $\mathrm{LCOH}$, cascading applications to decrease the return temperature must be considered, which include geothermal based greenhouse heating or geothermal snow melting under pathways and for the tracks of the university personal rapid transition (PRT) system. Additionally, increase in the maximum flow rate of the production well along with improved well technology is recommended. From the cost model of WVU case study, it can be inferred that for a lower return temperature assumed at $30^{\circ} \mathrm{C}$ and for maximum flow rate of $65 \mathrm{~kg} / \mathrm{s}$, the $\mathrm{LCOH}$ for the GDHC system is calculated at \$13.61/MMBtu.

Based on the cost model of WVU case study, LCOH was derived as a function of population density and geothermal gradient. The geothermal gradient in WV was calculated in the range of 12 to $30^{\circ} \mathrm{C} / \mathrm{km}$. There are 23 census tracts with the estimated LCOH below \$30/MMBtu, which are concentrated in Monongalia county, Kanawha county, and Cabell county. Minimum LCOH is observed in Morgantown, where WVU is located. LCOH decreases with the increase in geothermal gradient and population density. The population density shows a strong negative effect on $\mathrm{LCOH}$ at any geothermal gradient, while the gradient only shows a negative effect at a low population density. 


\section{Chapter 4}

\section{Conclusions and Recommendations}

\subsection{Significance and Conclusions}

Geothermal district heating and cooling has the potential to offset a considerable amount of fossil fuels consumption in the U.S. The GDHC system produces a more stable baseload energy while produces much less greenhouse gas and particulates emissions than conventional heating and cooling systems. However, the literatures on studies analyzing the economic impacts of installing or retrofitting existing systems are few in number. This study is unique in that its purpose was to utilize supply analyses for the GDHC systems and determine an appropriate economic assessment of the viability and sustainability of the systems. The significance of this study is to present a cost model for the GDHC system which for the first time takes the energy market demand into consideration for a geothermal project. By showing the technical feasibility and economic benefits of the GDHC systems, this study bridges the gap between theoretic design of the system and popularizing it among the public. Developing GDHC systems will help the national energy industry restructure to a more renewable and sustainable oriented system, and protect the national energy security. By evaluating the opportunities to develop GDHC systems in the United States, the following conclusions were made by this study:

$>$ The western U.S. is much more geothermally active than the eastern part. The overall geothermal potential is estimated with a mean of $273,100 \mathrm{MW}_{\text {th }}$, with levelized cost of heat ( $\mathrm{LCOH})$ as low as \$ 6.74/MMBtu, at Weiser in Idaho. Usually, the LCOH of the identified hydrothermal resource is the cheapest. The reservoir stimulation cost causes the near hydrothermal EGS has a higher LCOH. The most expensive one is the undiscovered hydrothermal resource due to the high exploration cost. 
The undiscovered hydrothermal resources are predicted to be concentrated in the states of California, Nevada, Hawaii, Alaska, and Oregon. Future geothermal exploration activities should more on such areas. Among the undiscovered resources, over $60 \mathrm{GW}_{\text {th }}$ of geothermal energy is with a LCOH lower than natural gas based heating system (\$9.2/MMBtu), and other $35 \mathrm{GW}_{\text {th }}$ of geothermal energy is with a LCOH lower than \$ 25/MMBtu.

The hot impermeable surroundings of the hydrothermal reservoir can also be used for geothermal applications, which are known as the near hydrothermal EGS resources. Apart from the fact that the near hydrothermal EGS resources have a bit higher $\mathrm{LCOH}$ than their corresponding hydrothermal resources, this category is the least expensive EGS resource. With the fact that most of the high quality hydrothermal resources have already been developed for other geothermal applications, the near hydrothermal EGS resources are worth considering for expanding the current energy system.

$>$ The high temperature and high flow rate of the geothermal resources are the key parameters when choosing a GDHC site. The local energy demand is the most important factor for the success of a GDHC system. Long distances between source and supply of the hot water would cause severe heat loss, so the GDHC system must built close to the energy market.

For hydrothermal and near hydrothermal EGS, since the reservoir depth is fixed, the geothermal gradient effect on $\mathrm{LCOH}$ is not significant. Sensitivity analysis shows that local energy demand, reservoir temperature and project lifetime have negative effects on $\mathrm{LCOH}$, while discount rate, well capital and surface capital have positive effects on $\mathrm{LCOH}$. Increasing the energy demand is the most effective way to decrease $\mathrm{LCOH}$.

A GDHC system based on West Virginia University campus is simulated as a preliminary case study which helps for detailed EGS based GDHC system research in the future. Results show that a doublet geothermal well system (one injection and one production), which is drilled to $5.25 \mathrm{~km}$ to ensure a geothermal 
temperature of $148.9^{\circ} \mathrm{C}$ can provide sufficient energy for the Evansdale campus heating and cooling demand. Maximum flow rate of $50 \mathrm{~kg} / \mathrm{s}$ should be maintained at peak energy demand. The $\mathrm{LCOH}$ is calculated as $\$ 14.33 / \mathrm{MMBtu}$, which is higher than the current steam based system (\$12/MMBtu).

With Southern Methodist University Geothermal Lab's finding of the elevated geothermal temperature in $\mathrm{WV}$, the $\mathrm{LCOH}$ of developing GDHC systems in WV is calculated for every census tract. The potential locations are concentrated in Monongalia County, Kanawha County, and Cabell County. Minimum LCOH is observed in Morgantown, where WVU is located. LCOH results show that the target area's population density has a strong negative effect on LCOH at any geothermal gradient, while the gradient only has a negative effect on LOCH at a low population density.

\subsection{Recommendations}

This project serves as a basis about where to develop the GDHC systems. People should consider the following aspects when developing any practical GDHC project based on this research, since assumptions and simplifications have been used.

In this research, the GDHC system is designed to provide heating and cooling energy for all the people in the target location. Study of Bloomquist and Lund shows consumers still have great reluctance in accepting the GDHC systems, especially if an extra fee for retrofit is needed (Bloomquist and Lund, 2000). Therefore, a careful energy market evaluation is recommended.

$>$ To further extract energy from geothermal water, cascading applications are recommended to decrease the return temperature. If the return temperature of WVU case study decreases from 40 to $30^{\circ} \mathrm{C}$, the $\mathrm{LCOH}$ can decreases by $5 \%$. For EGS resources, any technique that can increase the maximum flow rate of the production well is also recommended. 
The WVU case study does not provide in depth study on reservoir availability for a GDHC system. Future work is recommended to focus on geologic study, lithology study, and seismic study in Morgantown area, to ensure the availability of a sufficient water flow rate for the system.

The cost model in this research is the first ever cost model of geothermal energy which is designed for the GDHC system. It is recommended to couple this cost model with the reservoir simulation software to enable a more comprehensive analysis of the GDHC system. It is also recommended to enable this cost model for other kinds of geothermal direct uses.

Population density varies with the size of the target area. This research assumes the target area to be one square mile when designing the distribution network. The effect of choosing a larger or smaller target area remains unknown. In one hand, it changes the population density, and hence the energy demand; on the other hand, it changes the surface distribution network. Further work is recommended which enables the facility of choosing an optimum target area for the GDHC system.

This study proposed a novel method of analyzing the feasibility of geothermal energy, in addition to illustrating the need for environmentally-safe, renewable energy sources to meet legislation requirements. As demand for energy continues to rise, GDHC development may provide key assistance in providing a cleaner future on a global scale. 


\section{Reference}

Asif, M., Muneer, T. (2007) Energy supply, its demand and security issues for developed and emerging economies. Renewable and Sustainable Energy Reviews, 11:13881413.

Augustine, C., Young, K. R., and Anderson, A. (2010). Updated US geothermal supply curve. Proceedings, 35th Workshop on Geothermal Reservoir Engineering, Stanford University, Stanford, USA.

Blackwell, D., Richards, M., Frone, Z., Batir, J., Williams, M., Ruzo, A., and Dingwall, R. (2011) SMU Geothermal Laboratory Heat Flow Map of the Conterminous United States. Supported by Google.org. Available at http://www.smu.edu/geothermal.

Blackwell, D., Frone, Z., Richards, M., (2010). Elevated Crustal Temperatures in West Virginia: Potential for Geothermal Power. Huffington Department of Earth Sciences Geothermal Laboratory, Southern Methodist University.

Blackwell, D., and Richards, M. (2004). Geothermal map of North America, AAPG Map, scale 1:6,500,000, Product Code 423. Southern Methodist University Geothermal Lab.

Blair, J. M. (1978). Control of oil. Vintage Books.

Bloomquist, R. G. (1985). Evaluation and ranking of geothermal resources for electrical generation or electrical offset in Idaho, Montana, Oregon and Aashington, Executive Summary. Washing State Energy Office, Olympia, USA.

Bloomquist, R. G., and Lund, J. (2000). Resource development potential-revenue generation potential: only a balanced approach can lead to district energy development. TRANSACTIONS-GEOTHERMAL RESOURCES COUNCIL, 13-18.

Bowman, R. A., Mueller, A. C., \& Nagle, W. M. (1940). Mean temperature difference in design. Trans. ASME, 62(4), 283-294. 
Bureau of Labor Statistics (BLS) Employment Cost Index (ECI) (2013). Private industry - Utilities. CIS2014400000000I at http://www.bls.gov/ncs/ect/data.htm

Castle, J.W., Byrnes, A.P., (2005) Petrophysics of Lower Silurian sandstones and integration with the tectonic-stratigraphic framework, Appalachian basin, United States. American Association of Petroleum Geologist Bulletin, 89-1, pp. 41-60.

Chamorro César, Mondéjar María, Ramos Roberto, Segovia José, Martín María, Villamañán Miguel. (2012) World geothermal power production status: Energy, environmental and economic study of high enthalpy technologies. Energy, 42(2012):10-18.

Chen, N. H. (1979). An explicit equation for friction factor in pipe. Industrial \& Engineering Chemistry Fundamentals, 18(3), 296-297.

Cook, T. R., Dogutan, D. K., Reece, S. Y., Surendranath, Y., Teets, T. S., and Nocera, D. G. (2010). Solar energy supply and storage for the legacy and nonlegacy worlds. Chemical reviews, 110(11), 6474-6502.

Edenhofer, O., Pichs-Madruga, R., Sokona, Y., Seyboth, K., Matschoss, P., Kadner, S., Zwickel, T., Eickemeier, P, Hansen, G., Schlömer, S., Stechow, C. (2011) IPCC Entingh, D. J., Petty, S., and Livesay, B. J. (1988). IMGEO-Impact of R\&D on cost of geothermal power: Documentation and model version 2.09. Sandia National Laboratory.

Entingh, D. J. (2006). Introduction to the geothermal electricity technology evaluation model (GETEM), Princeton Energy Resources International.

Erdogmus, B., Toksoy, M., Ozerdem, B., and Aksoy, N. (2006). Economic assessment of geothermal district heating systems: A case study of Balcova-Narlidere, Turkey. Energy and buildings, 38(9), 1053-1059.

Fraas, A. P. (1989). Heat exchanger design. John Wiley \& Sons. 
Gao, H., Chen, Z., Osadetz, K. G., Hannigan, P., and Watson, C. (2000). A pool-based model of the spatial distribution of undiscovered petroleum resources. Mathematical Geology, 32(6), 725-749.

Garside, L., (1994). Description of Nevada Thermal Springs and Wells by County. Nevada Bureau Geothermal Technologies Program.

Gifford, J.S., Grace, R.C. (2011). CREST: Cost of renewable energy spreadsheet tool. National Renewable Energy Laboratory.

Giggenbach, W. F. (1988). Geothermal solute equilibria. derivation of Na-K-Mg-Ca geoindicators. Geochimica et cosmochimica acta, 52(12), 2749-2765.

Gilman, P., and Dobos, A. (2012). System Advisor Model, SAM 2011.12. 2: General Description (No. NREL/TP-6A20-53437). National Renewable Energy Laboratory.

Glassley, W. (2010) Geothermal Energy: Renewable Energy and the Environment. $C R C$ Press.

Gordon, R. L. (1975). Economic analysis of coal supply: an assessment of existing studies (No. PB-243220). Pennsylvania State Univ., University Park, USA.

Gudmudsson, J., Freeston, D., Lienau, P. (1985) The Lindal Diagram. Geothermal Resources Council Transaction, Vol 9-Part 1.

Gunnlaugsson, E. (2008). District heating in Reykjavík; past-present-future. In UNU Geothermal Training Programme. 30th Anniversary Workshop, Reykjavík, Iceland.

He, X., and Anderson, B. J. (2012). Low-temperature geothermal resources for district heating: an energy-economic model of West vlVirginia University case study. Proceedings, 37th Workshop on Geothermal Reservoir Engineering, Stanford University, Stanford, USA. 
Hefley, B., and Seydor, S. (2011). The economic impact of the value chain of a Marcellus shale well. University of Pittsburgh.

Hurter, S., Kohler, S., Saadat, A., Holl, H.G., Rockel, W., Trautwein, U., Zimmermann, G., Wolfgramm, M., and Huenges, E., (2002) Stimulating low permeability aquifers: Experiments in Rotliegend Sandstones, NE Germany. Geothermal Resources Council Transactions.

Karingithi, C.W., (2009). Chemical geothermometers for geothermal exploration. Proceedings, Exploration for Geothermal resources, Lake Naivasha, Kenya.

Kasameyer, R. (1997). Brief guidelines for the development of inputs to CCTS from the technology working group-working draft, Lawrence Livermore Laboratory, Livermore, CA.

Kilian, L. (2006). Not all oil price shocks are alike: disentangling demand and supply shocks in the crude oil market. CEPR Discussion Paper No. 5994, available at SSRN: http://ssrn.com/abstract=975262.

Klein, C.W., Lovekin, J.W., Sanyal, S.K. (2004). New geothermal site identification and qualification. GeothermEX, Inc.

Kline, D., Heimiller, D., and Cowlin, S. (2008). A GIS method for developing wind supply curves. National Renewable Energy Laboratory.

Labay, D. G., and Kinnear, T. C. (1981). Exploring the consumer decision process in the adoption of solar energy systems. Journal of consumer research, 271-278.

Lashof, D., Ahuja, D. (1990) Relative contributions of greenhouse gas emission to global warming. Nature, 344: 529-531.

Lee, K. C. (1996). Classification of geothermal resources an engineering approach. Proceedings, 21th Workshop on Geothermal Reservoir Engineering, Stanford University, Stanford, USA. 
Lei, H., and Valdimarsson, P. (2009). District heating modelling and simulation. Proceedings, 34th Workshop on Geothermal Reservoir Engineering, Stanford University, Stanford, USA.

Lienau P., Lunis B. (1998) Geothermal direct use engineering and design book. Oregon Institution of Technology.

Lovekin, J. (2004). Geothermal inventory. Bulletin Geothermal Resources Council, 33(6), 242-244.

Lund, J., Freeston, D., Boyd, T., (2010). Direct application of geothermal energy: 2010 worldwide review. World Geothermal Congress.

Lund, J. W., Freeston, D. H., and Boyd, T. L. (2011). Direct utilization of geothermal energy 2010 worldwide review. Geothermics, 40(3), 159-180.

Special Report on Renewable Energy Sources and Climate Change Mitigation. Cambridge University Press. Cambridge, United Kingdom and New York, USA.

Mahone, D. (1998). Absorption chillers. Southern California Gas Company.

Marcel, R. G., (2007). Technology status of direct geothermal utilization. Paper presented at European Geothermal Congress, Unterhaching, Germany.

McVeigh, J., Cohen, J., Vorum, M., Porro, G., and Nix, G. (2007). Preliminary technical risk technical risk analysis for the geothermal technologies program. National Renewable Energy Laboratory.

Mock, J. E., Tester, J. W., and Wright, P. M. (1997). Geothermal energy from the earth: its potential impact as an environmentally sustainable resource. Annual review of Energy and the Environment, 22(1), 305-356.

Muffler, L. J. P., and Guffanti, M. (1979). Assessment of geothermal resources of the United States--1978. US Geological Survey. 
Muffler, P., and Cataldi, R. (1978). Methods for regional assessment of geothermal resources. Geothermics, 7(2), 53-89.

Nathenson, M. (1975). Physical factors determining the fraction of stored energy recoverable from hydrothermal convection systems and conduction-dominated areas (No. USGS-OFR-75-525). Geological Survey, Menlo Park, USA.

New York State oil, gas and mineral resources annual report 2010. New York State Department of Environmental Conservation, Division of Mineral Resources.

Ozgener, L., Hepbasli, A., and Dincer, I. (2005). Energy and exergy analysis of Salihli geothermal district heating system in Manisa, Turkey. International Journal of Energy Research, 29(5), 393-408.

Pan, G. (1993). Indicator favorability theory for mineral potential mapping. Nonrenewable Resources, 2(4), 292-311.

Persson, U., AND Werner, S. (2011). Heat distribution and the future competitiveness of district heating. Applied Energy, 88(3), 568-576.

Petty, S., Livesay, B. J., Long, W. P., and Geyer, J. (1992). Supply of geothermal power from hydrothermal sources: A study of the cost of power in 20 and 40 years. Sandia National Laboratories.

Petty, S., Porro, G. (2007). Updated US geothermal supply characterization. Proceedings, 32th Workshop on Geothermal Reservoir Engineering, Stanford University, Stanford, USA.

Priest, S. S., Blanton, A. J., Sacket, P. C., Welch, S. L., and MA, W. (2000).Geothermal industry temperature profiles from the Great Basin. US Geological Survey.

Reed, M. J. (1982). Assessment of low-temperature geothermal resources of the United States-1982 (No. USGS-CIRC-892). US Geological Survey, Menlo Park, USA. 
Ryder, R.T., Crangle, R.D., Trippi, M.H., Swezey, C.S., Lentz, E.E., Rowan, E.L., and Hope, R.S. (2009). Geologic cross section D-D' through the Appalachian basin from the Findlay arch, Sandusky County, Ohio, to the Valley and Ridge province, Hardy County, West Virginia. U.S. Geological Survey Scientific Investigations Map 3067, 2 sheets, 52-p. pamphlet.

Sanyal, S. K. (2004). Cost of geothermal power and factors that affect it. Proceedings, 29th Workshop on Geothermal Reservoir Engineering, Stanford University, Stanford, USA.

Shah, R. K., and Sekulic, D. P. (2003). Fundamentals of heat exchanger design. John Wiley \& Sons.

Smith, R. L., and Shaw, H. R. (1979). Igneous-related geothermal systems. US Geologic Survey Circular, 790, 12-17.

Somers, C., Mortazavi, A., Hwang, Y., Radermacher, R., Rodgers, P., \& Al-Hashimi, S. (2011). Modeling water/lithium bromide absorption chillers in ASPEN Plus. Applied Energy, 88(11), 4197-4205.

Stevenson, P. (2014). The potential for recovering and using surplus heat from industry. Department of Energy \& Climate Change, UK.

Tenzer, H. (2001). Development of hot dry rock technology. Bulletin Geo-Heat Center, Oregon Institution of Technology, USA.

Tester, J. W., Anderson, B. J., Batchelor, A. S., Blackwell, D. D., DiPippo, R., Drake, E. M., ... and Veatch, R. W. (2006). The future of geothermal energy: Impact of enhanced geothermal systems (EGS) on the United States in the 21st Century. Massachusetts Institute of Technology, Cambridge, USA.

Thorsteinsson, H. H. (2008). US geothermal district heating: barriers and enablers. Doctoral dissertation, Massachusetts Institute of Technology. 
Turton, R., Bailie, R. C., Whiting, W. B., and Shaeiwitz, J. A. (2008). Analysis, synthesis and design of chemical processes. Pearson Education.

U.S. Energy Information Administration Heating Fuels Comparison Calculator, (2013).

U.S. Energy Information Administration. (2013). Assumptions to the Annual Energy Outlook 2013.

U.S. Energy Information Administration. (2011). International Energy Statistics.

U.S. National Aeronautics and Space Administration. (2012). GISS Surface Temperature Analysis.

Valdimarsson, P. (1993). Modelling of geothermal district heating systems. University of Iceland, Faculty of Engineering.

White, D. E., and Williams, D. L. (1975). Assessment of geothermal resources of the United States--1975 (No. USGS-75-726). Geological Survey Circular.

Williams, C. F. (2004). Development of revised techniques for assessing geothermal resources. Proceedings, 29th Workshop on Geothermal Reservoir Engineering, Stanford University, Stanford, USA.

Williams, C. F., and DeAngelo, J. (2008). Mapping geothermal potential in the western United States. Geothermal Resources Council Transactions, 32, 181.

Williams, C. F., Reed, M. J., Mariner, R. H., DeAngelo, J., and Galanis Jr, S. P. (2008). Assessment of moderate-and high-temperature geothermal resources of the United States. US Geological Survey fact sheet, 3082(4).

Williams, C. F., Reed, M. J., Mariner, R. H., DeAngelo, J., and Galanis Jr, S. P. (2009). Quantifying the undiscovered geothermal resources of the United States. US Geologic Survey, Geothermal Resources Council Transactions, 33, 995-1001.

Xia, L., Lorente, S., and Bejan, A. (2011). Constructal design of distributed cooling on the landscape. International Journal of Energy Research, 35(9), 805-812. 
Yildirim, N., Toksoy, M., and Gökçen, G. (2006). District heating system design for a university campus. Energy and buildings, 38(9), 1111-1119.

Young, K. R., Augustine, C., and Anderson, A. (2010). Report on the US DOE Geothermal Technologies Program's 2009 Risk Analysis. Proceedings, 35th Workshop on Geothermal Reservoir Engineering, Stanford University, Stanford, USA. 


\section{Appendix A: Geothermal Reservoir Characteristics and $\mathrm{LCOH}$}

Table A-1: Identified Hydrothermal Resources and Near Hydrothermal EGS

\begin{tabular}{|c|c|c|c|c|c|c|c|c|c|c|}
\hline $\begin{array}{l}\stackrel{\mathscr{E}}{\Xi} \\
\text { Z }\end{array}$ & & 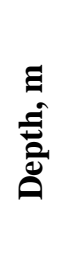 & 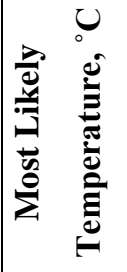 & 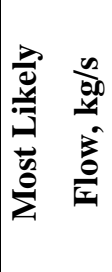 & 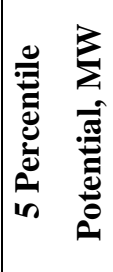 & 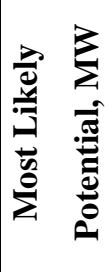 & 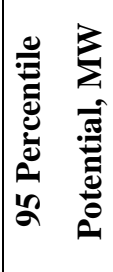 & 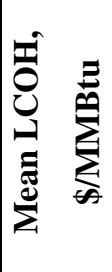 & 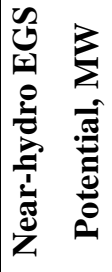 & 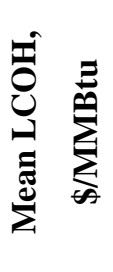 \\
\hline $\begin{array}{l}\bar{d} \\
\frac{2}{2} \\
\bar{d} \\
3\end{array}$ & 最 & ఫ్రి & ฉ̊ & 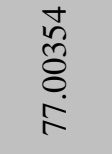 & $\begin{array}{l}n \\
\infty \\
\infty \\
2 \\
\infty \\
i\end{array}$ & 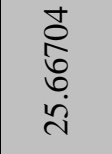 & $\begin{array}{l}1 \\
\delta \\
0 \\
\infty \\
\tilde{n} \\
\end{array}$ & $\underset{\sigma}{\stackrel{t}{0}}$ & 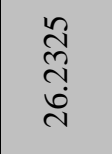 & $\underset{\infty}{\infty}$ \\
\hline 莺 & $\begin{array}{l}\text { Õ } \\
\tilde{a} \\
\tilde{1}\end{array}$ & ڤิ & $\varrho$ & 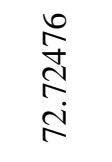 & $\begin{array}{l}\vec{ָ} \\
\underset{\forall}{\sigma} \\
\stackrel{+}{+}\end{array}$ & $\begin{array}{l}\infty \\
\infty \\
\infty \\
\infty \\
\infty \\
\text { ते }\end{array}$ & 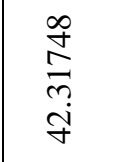 & $\begin{array}{l}\mathscr{q} \\
\dot{ \pm}\end{array}$ & $\begin{array}{l}\vec{\sigma} \\
\hat{\sigma} \\
\stackrel{a}{a}\end{array}$ & $\begin{array}{l}n \\
n \\
0\end{array}$ \\
\hline छे & نَ & : & ষ্ల & 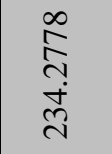 & $\begin{array}{l}\frac{m}{\sigma} \\
\dot{\delta}\end{array}$ & $\begin{array}{l}\bar{N} \\
\bar{a} \\
\stackrel{\sim}{i}\end{array}$ & 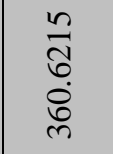 & $\underset{\infty}{\infty}$ & 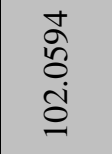 & $\frac{m}{a}$ \\
\hline 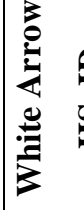 & $\begin{array}{l}\text { 是 } \\
\hat{1}\end{array}$ & in & 8 & $\frac{\Xi}{\bar{a}}$ & $\begin{array}{l}\underset{N}{\hat{0}} \\
\stackrel{\sim}{+} \\
\dot{\sigma}\end{array}$ & 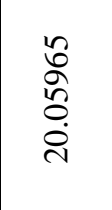 & $\frac{5}{\frac{5}{7}}$ & $\stackrel{\text { I }}{\text { I }}$ & $\begin{array}{l}\text { N } \\
\text { D. } \\
\text { I }\end{array}$ & $\begin{array}{l}8 \\
\dot{ \pm}\end{array}$ \\
\hline 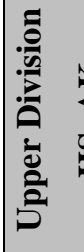 & $\begin{array}{l}\text { है } \\
\text { की }\end{array}$ & ڤิ & $\stackrel{\varrho}{\exists}$ & $\begin{array}{l}\text { ले } \\
\text { } \\
\infty \\
\text { nं }\end{array}$ & $\begin{array}{l}\hat{\infty} \\
\hat{\sigma} \\
0 \\
\stackrel{r}{r}\end{array}$ & $\begin{array}{l}\hat{\infty} \\
\bar{n} \\
m\end{array}$ & $\frac{\sqrt[n]{n}}{\frac{\pi}{6}}$ & $\frac{n}{\sigma}$ & $\begin{array}{l}\text { aे } \\
\text { wn } \\
\text { aे }\end{array}$ & ঐे \\
\hline 葛 & 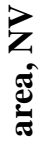 & \&్ర & 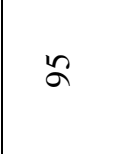 & $\begin{array}{l}\frac{n}{n} \\
\text { ọ } \\
\text { n }\end{array}$ & \begin{tabular}{l}
$\stackrel{2}{2}$ \\
\multirow{2}{2}{} \\
$\stackrel{i}{i}$
\end{tabular} & 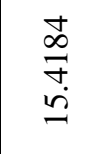 & $\begin{array}{l}0 \\
\stackrel{0}{0} \\
\stackrel{0}{0} \\
\stackrel{2}{0}\end{array}$ & $\begin{array}{l} \pm \\
\infty \\
-\infty\end{array}$ & $\begin{array}{l}\infty \\
\infty \\
\curvearrowright \\
\dot{ \pm}\end{array}$ & 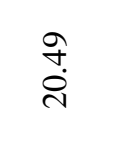 \\
\hline 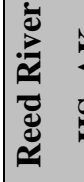 & \begin{tabular}{l}
4 \\
\multirow{2}{*}{} \\
0
\end{tabular} & กิ & 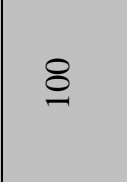 & $\begin{array}{l}\frac{n}{1} \\
\cdots \\
8 \\
8\end{array}$ & 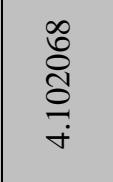 & 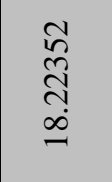 & \begin{tabular}{l}
\multirow{J}{0}{} \\
$\stackrel{\infty}{7}$ \\
$\dot{m}$
\end{tabular} & $\begin{array}{l}\stackrel{0}{0} \\
\dot{0}\end{array}$ & $\begin{array}{l}+ \\
\infty \\
\stackrel{\sim}{n} \\
\end{array}$ & $\begin{array}{l}\stackrel{0}{+} \\
\dot{T}\end{array}$ \\
\hline
\end{tabular}




\begin{tabular}{|c|c|c|c|c|c|c|c|c|c|c|}
\hline 总 & z & ষ্ల & 8 & 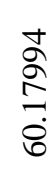 & 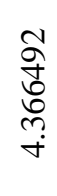 & $\begin{array}{l}\text { ले } \\
\stackrel{2}{\text { సे }} \\
\stackrel{2}{2}\end{array}$ & $\begin{array}{l}\stackrel{\circ}{2} \\
\stackrel{2}{1} \\
\dot{n}\end{array}$ & $\begin{array}{l}\vec{J} \\
\infty \\
\infty\end{array}$ & \begin{tabular}{l}
0 \\
0 \\
\multirow{2}{0}{} \\
$ِ$
\end{tabular} & $\stackrel{\infty}{\stackrel{\infty}{*}}$ \\
\hline $\begin{array}{l}00 \\
\frac{0}{3} \\
\frac{0}{0} \\
3 \\
3\end{array}$ & $\begin{array}{l}\text { Õ } \\
\hat{\Xi}\end{array}$ & त् & 8 & $\frac{\infty}{\underset{f}{\dot{f}}}$ & 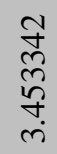 & 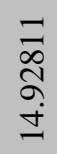 & 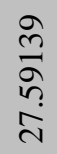 & $\begin{array}{l}\infty \\
\stackrel{\infty}{\sim} \\
\end{array}$ & $\begin{array}{l}\text { ㅁ } \\
\stackrel{i}{i} \\
\text { In }\end{array}$ & $\begin{array}{l}\hat{6} \\
\ddot{n}\end{array}$ \\
\hline 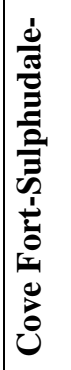 & 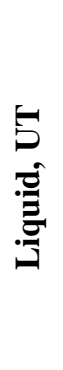 & $\stackrel{8}{\circ}$ & 으 & $\begin{array}{l}\stackrel{N}{f} \\
\stackrel{+}{\sim} \\
\text { d }\end{array}$ & 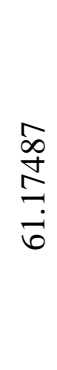 & $\begin{array}{l}\hat{2} \\
\text { nे } \\
\end{array}$ & 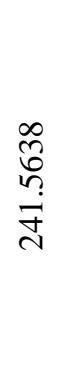 & $\begin{array}{l}\infty \\
\infty \\
\stackrel{\sim}{0}\end{array}$ & $\begin{array}{l}\frac{\hat{n}}{6} \\
\dot{\sigma} \\
\bar{a}\end{array}$ & $\begin{array}{l}+ \\
\text { ¿ } \\
\text { i }\end{array}$ \\
\hline 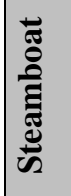 & 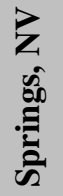 & ్ㅗ & $\sqrt{6}$ & 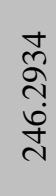 & 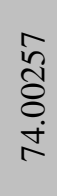 & $\begin{array}{l}\hat{8} \\
\hat{n} \\
\dot{2}\end{array}$ & $\begin{array}{l}\hat{2} \\
\text { n̊ } \\
\stackrel{0}{0}\end{array}$ & $\stackrel{\ddot{n}}{n}$ & \begin{tabular}{l}
$\vec{\infty}$ \\
\multirow{+}{*}{} \\
$\sim$ \\
$\tilde{\sigma}$
\end{tabular} & 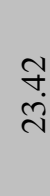 \\
\hline 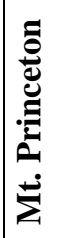 & 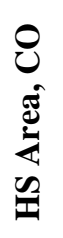 & \& & $\curvearrowleft$ & 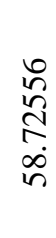 & 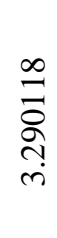 & $\begin{array}{l}\stackrel{n}{\Xi} \\
\stackrel{n}{N} \\
\stackrel{n}{=}\end{array}$ & $\begin{array}{l}\hat{D} \\
\tilde{n} \\
\hat{0} \\
\dot{n} \\
m\end{array}$ & $\stackrel{ }{\stackrel{N}{0}}$ & $\begin{array}{l}n \\
\infty \\
n \\
n\end{array}$ & $\begin{array}{l}\mathfrak{d} \\
\ddot{i}\end{array}$ \\
\hline 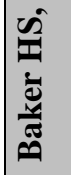 & $\overleftarrow{3}$ & त् & $\stackrel{n}{=}$ & 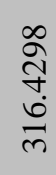 & 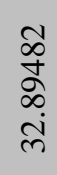 & $\begin{array}{l} \pm \\
\infty \\
\infty \\
\infty \\
=\end{array}$ & $\begin{array}{l}0 \\
0 \\
\dot{0} \\
\stackrel{\sim}{v}\end{array}$ & $\bar{m}$ & $\begin{array}{l}\text { } \\
\text { ๙ } \\
\text { }\end{array}$ & $\begin{array}{l}8 \\
\stackrel{0}{ }\end{array}$ \\
\hline 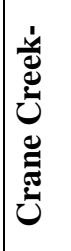 & 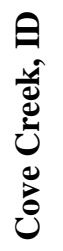 & ஜ̊ & $\stackrel{n}{n}$ & 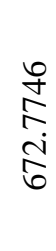 & 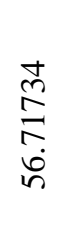 & $\begin{array}{l}n \\
\infty \\
\infty \\
0 \\
0 \\
0 \\
n\end{array}$ & 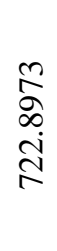 & 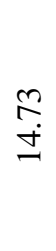 & 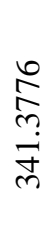 & $\stackrel{\infty}{\stackrel{\infty}{0}}$ \\
\hline 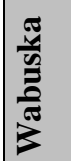 & $\begin{array}{l}\vec{z} \\
\hat{\mathbf{I}}\end{array}$ & त् & $\stackrel{n}{=}$ & $\begin{array}{l}n \\
\tilde{\delta} \\
0 \\
\\
\end{array}$ & $\begin{array}{l}\bar{\nabla} \\
\stackrel{\oplus}{+} \\
\stackrel{0}{0}\end{array}$ & $\begin{array}{l}\tilde{\sigma} \\
\tilde{\sigma} \\
\dot{b} \\
+\end{array}$ & $\begin{array}{l}\infty \\
\infty \\
\infty \\
\infty \\
\dot{0} \\
\infty\end{array}$ & $\begin{array}{c}\hat{\sim} \\
\infty\end{array}$ & $\begin{array}{l}\stackrel{\circ}{\sigma} \\
\stackrel{\sigma}{\sigma} \\
\stackrel{\rho}{2}\end{array}$ & $\begin{array}{l}\sigma \\
\infty \\
\sigma\end{array}$ \\
\hline 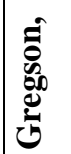 & $\sum$ & ్ㅗㄱ & $\stackrel{\varrho}{ }$ & $\begin{array}{l}\hat{\delta} \\
\text { مे } \\
\hat{n} \\
\text { aे }\end{array}$ & 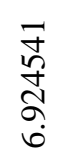 & 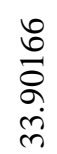 & $\begin{array}{l}\stackrel{2}{n} \\
\stackrel{f}{f} \\
\ddot{\sigma}\end{array}$ & $\begin{array}{l}\stackrel{\vartheta}{*} \\
\infty\end{array}$ & $\begin{array}{l}\bar{\infty} \\
\underset{\sim}{\infty}\end{array}$ & స్తి \\
\hline
\end{tabular}




\begin{tabular}{|c|c|c|c|c|c|c|c|c|c|}
\hline 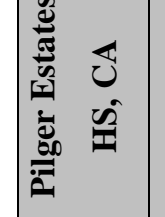 & $\underline{8}$ & $\therefore$ & 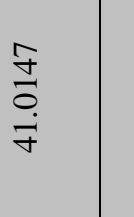 & 竞 & 总 & 旁噌 & 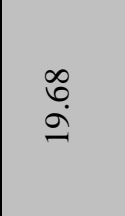 & 范 & สี \\
\hline & 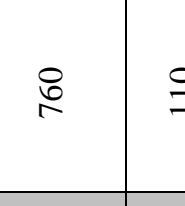 & $\cong$ & 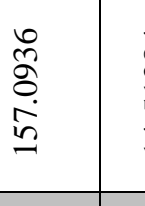 & 憘 & 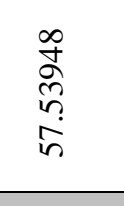 & 产 & $\overline{\bar{c}}$ & 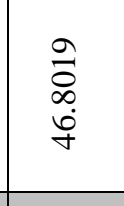 & : \\
\hline & $\bar{g}$ & $\therefore \frac{\bar{g}}{3}$ & 吾 & 㩊 & 峷 & 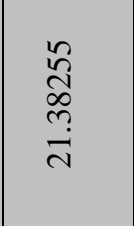 & $\underline{\mathscr{x}}$ & 善 & 彞 \\
\hline & $\stackrel{g}{g}$ & 呈 & 言 & 商 & 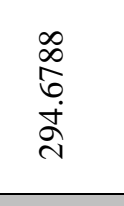 & 参 & : & 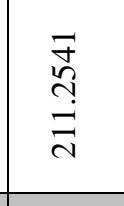 & 彜 \\
\hline 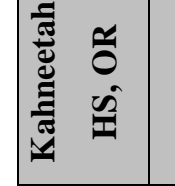 & 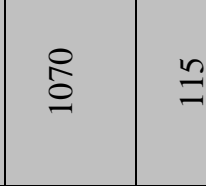 & $\cong$ & 皆 & 商 & 譬 & 高 & $\frac{\mathrm{g}}{\mathrm{g}}$ & 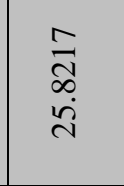 & $\frac{\mathscr{2}}{8}$ \\
\hline & $\cong$ & $\cong$ & 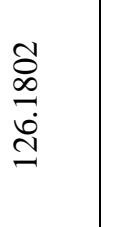 & 高 & 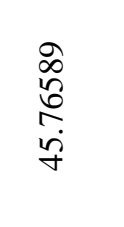 & 票 & ì & 害 & 㱛 \\
\hline | & $\approx$ & $\approx \frac{7}{\Xi}$ & 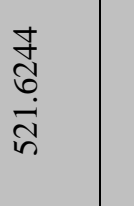 & 筞 & 嘉 & 产 & $\stackrel{g}{\stackrel{g}{g}}$ & 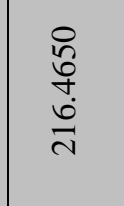 & $\frac{g}{d}$ \\
\hline 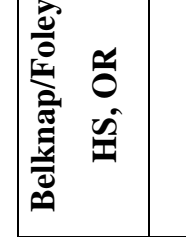 & $\cong$ & 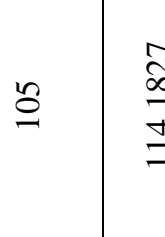 & 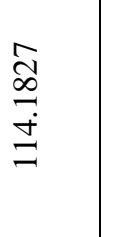 & 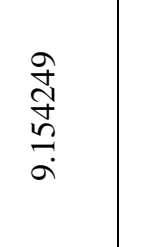 & 总 & $\frac{2}{2}$ & 焉 & 喜 & 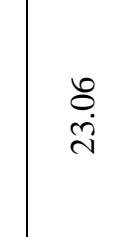 \\
\hline & $\cong$ & $\cong$ & & & & & $\overline{8}$ & 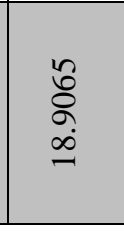 & \\
\hline
\end{tabular}




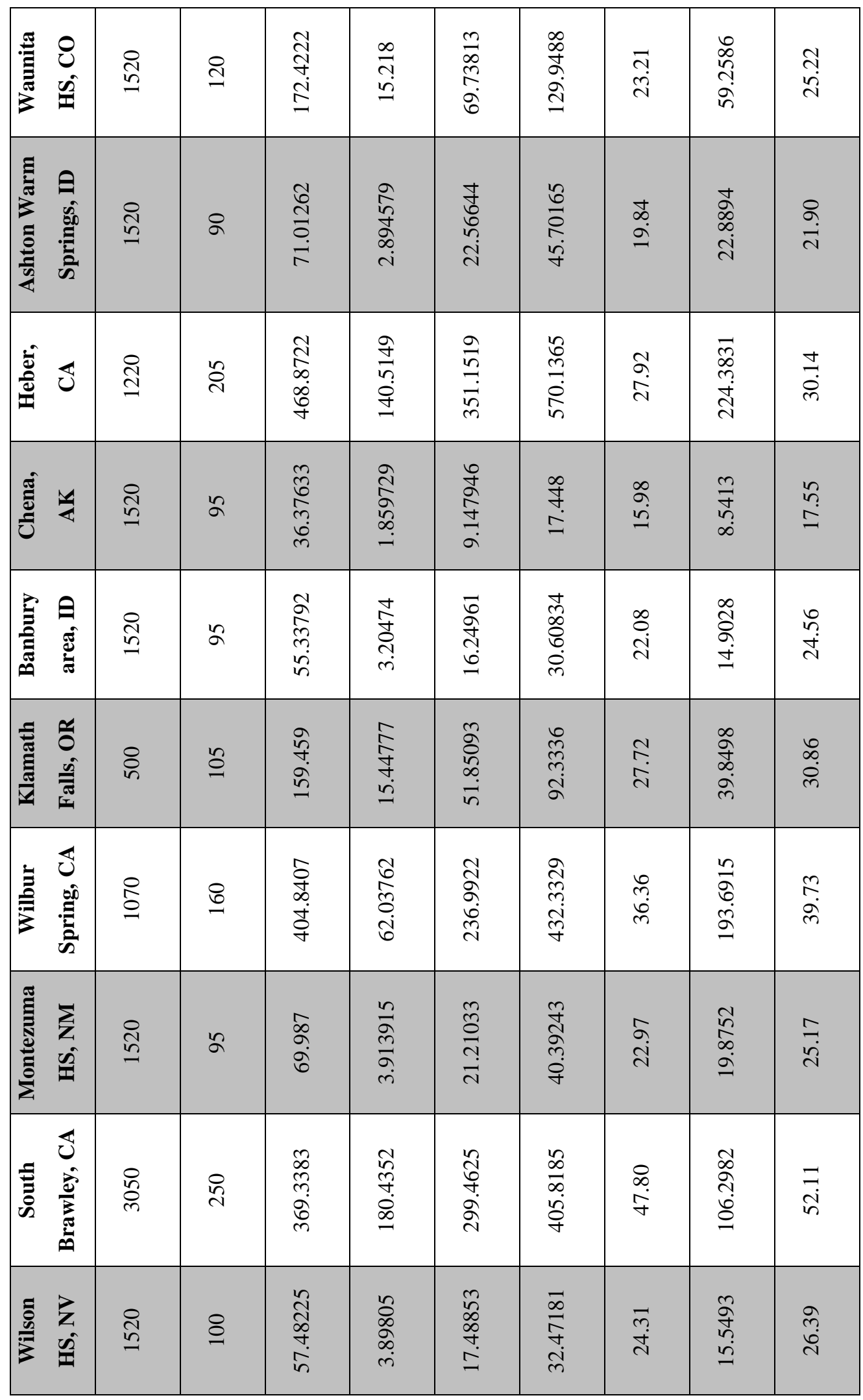




\begin{tabular}{|c|c|c|c|c|c|c|c|c|c|}
\hline 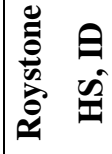 & तี & \& & 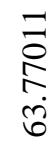 & $\begin{array}{l}\vec{J} \\
\stackrel{\sigma}{\sigma} \\
\infty \\
i \\
i\end{array}$ & \begin{tabular}{l}
$\hat{f}$ \\
\multirow{\sigma}{0}{} \\
$\infty$ \\
0 \\
0
\end{tabular} & 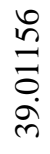 & $\underset{\stackrel{+}{d}}{\stackrel{+}{+}}$ & \begin{tabular}{l}
\multirow{2}{\alpha}{} \\
$\stackrel{\alpha}{\alpha}$
\end{tabular} & $\stackrel{\vec{N}}{\stackrel{N}{N}}$ \\
\hline 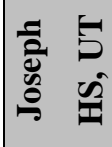 & $\begin{array}{l}\text { กิ } \\
\text { กิ- }\end{array}$ & ฉ̊ & $\frac{\hat{\sigma}}{\stackrel{\sigma}{+}}$ & 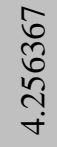 & \begin{tabular}{l}
0 \\
\multirow{+}{*}{} \\
$n$ \\
$\infty$ \\
-1
\end{tabular} & $\begin{array}{l}0 \\
\infty \\
\hat{\sigma} \\
\dot{n} \\
\dot{m}\end{array}$ & $\begin{array}{l}\text { ते } \\
\text { ते }\end{array}$ & $\begin{array}{l}\hat{n} \\
\hat{n} \\
n\end{array}$ & 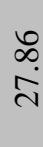 \\
\hline 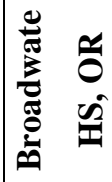 & 8 & $\stackrel{\imath}{\varrho}$ & $\frac{\frac{9}{5}}{\frac{\sigma}{6}}$ & 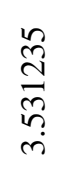 & 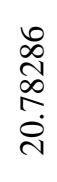 & 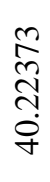 & $\begin{array}{l}m \\
\stackrel{0}{0}\end{array}$ & 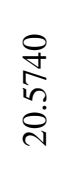 & $\underset{m}{\tilde{m}}$ \\
\hline 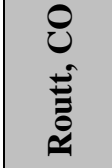 & กิ & $\stackrel{ }{=}$ & 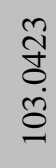 & 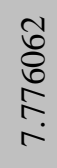 & 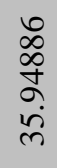 & 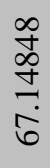 & $\begin{array}{l}\text { ָे } \\
\text { ñ }\end{array}$ & $\begin{array}{l}\tilde{D} \\
\infty \\
\dot{\infty} \\
\dot{\infty}\end{array}$ & $\stackrel{?}{\stackrel{n}{\sim}}$ \\
\hline 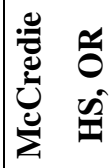 & 고 & $\stackrel{n}{a}$ & $\begin{array}{l}\stackrel{\infty}{ \pm} \\
\underset{\infty}{\infty} \\
\dot{J}\end{array}$ & $\begin{array}{l}\tilde{N} \\
\ddot{n} \\
\infty \\
\infty \\
\dot{n}\end{array}$ & 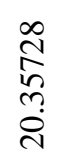 & 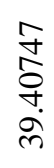 & $\frac{\mathfrak{r}}{\stackrel{i}{i}}$ & $\begin{array}{l}\text { ôn } \\
\text { nn } \\
\end{array}$ & 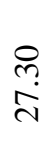 \\
\hline 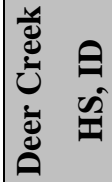 & $\begin{array}{l}0 \\
\infty \\
\infty\end{array}$ & $\stackrel{2}{\beth}$ & $\begin{array}{l}\hat{6} \\
\infty \\
0 \\
\dot{0} \\
0\end{array}$ & $\begin{array}{l}= \\
\stackrel{\infty}{\infty} \\
\stackrel{+}{=}\end{array}$ & 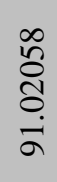 & 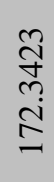 & $\begin{array}{l}\text { ڤे } \\
\text { ڤn }\end{array}$ & $\begin{array}{l}\stackrel{2}{2} \\
\infty \\
\infty \\
\infty\end{array}$ & $\begin{array}{l}\text { ते } \\
\text { i }\end{array}$ \\
\hline 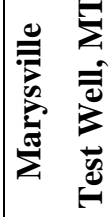 & \&్ర & 8 & $\begin{array}{l}\frac{a}{0} \\
\text { N } \\
\stackrel{ \pm}{v}\end{array}$ & $\underset{\stackrel{\infty}{+}}{\stackrel{\infty}{+}}$ & 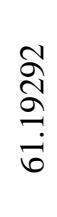 & 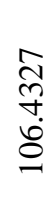 & $\frac{+}{\vec{d}}$ & 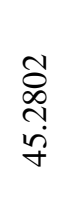 & 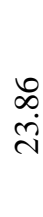 \\
\hline 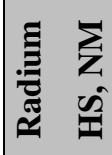 & त् & ฉ & 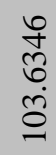 & \begin{tabular}{l}
$\infty$ \\
\multirow{f}{*}{} \\
$\stackrel{5}{f}$ \\
$\stackrel{+}{*}$
\end{tabular} & $\begin{array}{c}\frac{n}{2} \\
\stackrel{2}{a} \\
\frac{\infty}{n}\end{array}$ & $\begin{array}{l}\frac{\hat{\pi}}{2} \\
\hat{\sigma} \\
\hat{\gamma}\end{array}$ & $\stackrel{ }{\vec{\lambda}}$ & 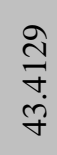 & $\begin{array}{l}\stackrel{+}{+} \\
\text { จे }\end{array}$ \\
\hline 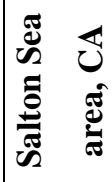 & ঐे & $\stackrel{\circ}{m}$ & 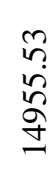 & \begin{tabular}{l}
$\hat{\infty}$ \\
\multirow{1}{*}{} \\
$\infty$ \\
$\infty$ \\
$\infty$
\end{tabular} & 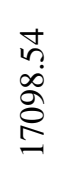 & $\begin{array}{l}\vec{j} \\
m \\
\infty \\
\infty \\
\tilde{d} \\
i\end{array}$ & $\begin{array}{l}\infty \\
\infty \\
i\end{array}$ & $\begin{array}{l}\frac{ \pm}{\sigma} \\
\infty \\
\dot{\alpha} \\
\text { ळे }\end{array}$ & $\overline{\text { ले }}$ \\
\hline 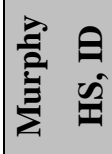 & กิ & 8 & 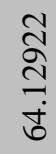 & $\begin{array}{l}\infty \\
\stackrel{\infty}{\sigma} \\
\stackrel{m}{n} \\
\dot{m}\end{array}$ & 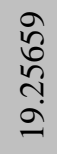 & 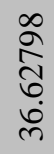 & $\begin{array}{l}8 \\
\stackrel{0}{0} \\
\text { i }\end{array}$ & $\begin{array}{l}\delta \\
\delta \\
\hat{\sigma} \\
\sigma\end{array}$ & $\begin{array}{l}n \\
\alpha \\
\infty \\
i\end{array}$ \\
\hline
\end{tabular}




\begin{tabular}{|c|c|c|c|c|c|c|c|c|c|}
\hline 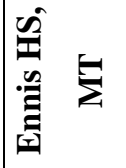 & त् & $\stackrel{n}{=}$ & 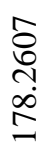 & 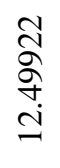 & $\begin{array}{l}\stackrel{0}{\mathbb{J}} \\
\stackrel{+}{+}\end{array}$ & $\begin{array}{l}\tilde{n} \\
\dot{J} \\
\dot{0} \\
\dot{J}\end{array}$ & 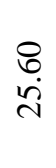 & 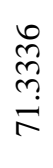 & 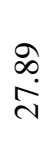 \\
\hline 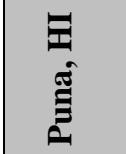 & $\stackrel{?}{0}$ & in & 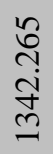 & $\begin{array}{l}8 \\
\qquad \\
2 \\
\infty\end{array}$ & $\begin{array}{l}\underset{N}{\sigma} \\
\tilde{\infty}\end{array}$ & $\begin{array}{l}\mathscr{\infty} \\
\infty \\
0 \\
\infty \\
\infty \\
0\end{array}$ & $\frac{\infty}{\dot{\dot{b}}}$ & 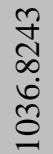 & $\begin{array}{l}\overline{0} \\
\ddot{n}\end{array}$ \\
\hline 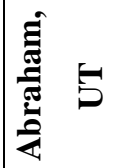 & $\begin{array}{l}\text { त్ } \\
\text { n. }\end{array}$ & ฉ & $\begin{array}{l}\frac{0}{n} \\
\frac{n}{2} \\
\text { in }\end{array}$ & $\begin{array}{l}\frac{n}{\infty} \\
\infty \\
\stackrel{n}{r} \\
i\end{array}$ & $\begin{array}{l}+ \\
\stackrel{\infty}{+} \\
\infty \\
\stackrel{+}{+} \\
\pm\end{array}$ & $\begin{array}{l}\infty \\
\stackrel{\infty}{N} \\
\infty \\
\infty \\
\infty\end{array}$ & $\frac{0}{\stackrel{\sim}{N}}$ & $\begin{array}{l}\circ \\
\stackrel{0}{0} \\
\dot{1} \\
\dot{2}\end{array}$ & 홍 \\
\hline 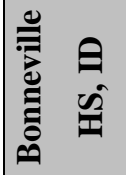 & तี & $\curvearrowleft$ & \begin{tabular}{l}
$\hat{b}$ \\
$\infty$ \\
\multirow{+}{+}{} \\
$\infty$
\end{tabular} & $\begin{array}{l}\frac{n}{2} \\
\frac{\sigma}{\sigma} \\
\dot{\sigma}\end{array}$ & 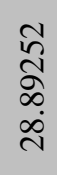 & $\begin{array}{l}\text { बे } \\
\text { हे } \\
\vdots \\
\dot{0}\end{array}$ & 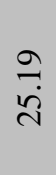 & 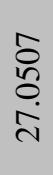 & $\stackrel{\text { }}{\stackrel{\sim}{N}}$ \\
\hline 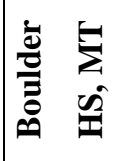 & $\begin{array}{l}\text { त్ } \\
\text { n. }\end{array}$ & 8 & $\begin{array}{l}0 \\
\stackrel{0}{\infty} \\
\stackrel{N}{N} \\
\dot{ர}\end{array}$ & 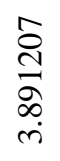 & 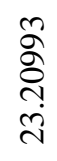 & $\begin{array}{l}\circ \\
\mathscr{D} \\
\infty \\
\infty \\
\dot{+}\end{array}$ & $\begin{array}{l}\infty \\
\infty \\
\ddot{\nu}\end{array}$ & $\begin{array}{l}\hat{\alpha} \\
\hat{o} \\
\text { in }\end{array}$ & $\begin{array}{l}\infty \\
\infty \\
\ddot{d}\end{array}$ \\
\hline 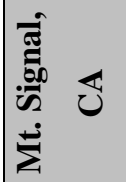 & त్ & $\stackrel{n}{n}$ & $\begin{array}{l}n \\
\tilde{n} \\
\infty \\
\dot{\delta} \\
\text { ठิ }\end{array}$ & $\begin{array}{l}\bar{a} \\
\text { d̦ } \\
\dot{j}\end{array}$ & $\begin{array}{l}\hat{\tilde{n}} \\
\stackrel{\delta}{\infty} \\
\hat{\infty}\end{array}$ & 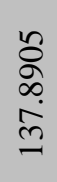 & $\begin{array}{l}\stackrel{\infty}{\sim} \\
\stackrel{\infty}{+}\end{array}$ & $\begin{array}{l}\stackrel{n}{n} \\
i n \\
\frac{n}{n}\end{array}$ & $\begin{array}{l}\text { J } \\
\text { तn }\end{array}$ \\
\hline 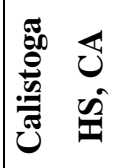 & त् & 肙 & $\begin{array}{l}\stackrel{n}{ \pm} \\
\stackrel{+}{+} \\
\stackrel{+}{\sim}\end{array}$ & $\frac{\dot{d}}{\text { d. }}$ & 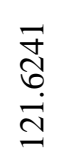 & $\begin{array}{l}\text { すे } \\
\dot{+} \\
\stackrel{a}{\alpha}\end{array}$ & $\stackrel{\vartheta}{\vec{\gamma}}$ & $\begin{array}{l}\hat{\sigma} \\
\infty \\
\hat{\sigma} \\
\hat{a}\end{array}$ & $\begin{array}{l}n \\
\mathfrak{n} \\
\mathfrak{f}\end{array}$ \\
\hline 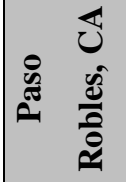 & ్ㅗ & $\curvearrowleft$ & $\begin{array}{l}\overline{8} \\
8 \\
n \\
\dot{7}\end{array}$ & 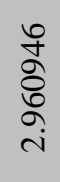 & 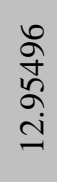 & 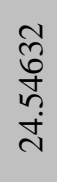 & $\frac{\tilde{n}}{\dot{m}}$ & $\begin{array}{l}\stackrel{0}{J} \\
\Xi \\
=\end{array}$ & $\begin{array}{l}\infty \\
\text { ले }\end{array}$ \\
\hline 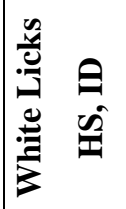 & 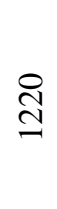 & $\stackrel{ }{=}$ & \begin{tabular}{l} 
ले \\
$\infty$ \\
\multirow{1}{*}{} \\
ปે
\end{tabular} & $\begin{array}{l}\hat{o} \\
2 \\
o \\
a\end{array}$ & $\begin{array}{l}n \\
\sqrt[n]{b} \\
\infty \\
\dot{7}\end{array}$ & 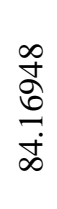 & $\begin{array}{l}\text { m. } \\
\text { mे }\end{array}$ & 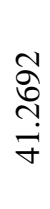 & $\begin{array}{l}\hat{\sigma} \\
\text { m }\end{array}$ \\
\hline 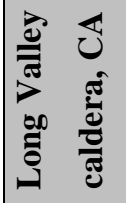 & ஜి & ?े & $\begin{array}{l}\text { aे } \\
\text { ஸे } \\
\text { ñ }\end{array}$ & 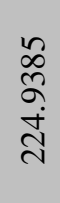 & 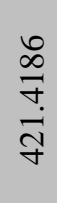 & 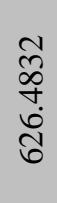 & \begin{tabular}{l}
$\infty$ \\
\multirow{n}{n}{} \\
$m$
\end{tabular} & 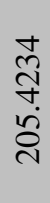 & $\begin{array}{l}\mathbb{8} \\
\infty \\
\infty \\
m\end{array}$ \\
\hline
\end{tabular}




\begin{tabular}{|c|c|c|c|c|c|c|c|c|}
\hline & \begin{tabular}{|l|l|}
$\underline{2}$ & $=$ \\
\end{tabular} & \begin{tabular}{l|l} 
萦 \\
\end{tabular} & 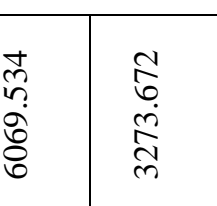 & 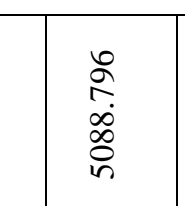 & 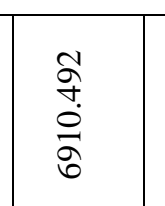 & 号 & 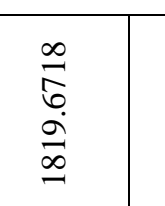 & $\frac{2}{p}$ \\
\hline & 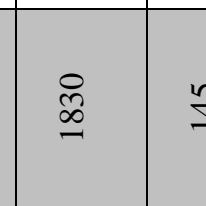 & 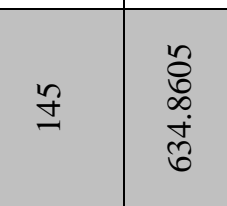 & 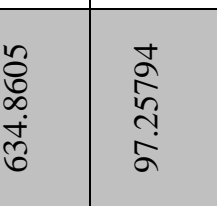 & 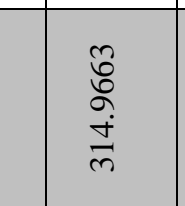 & 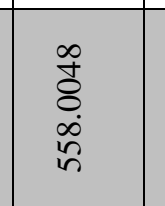 & $\frac{g}{\partial}$ & $\stackrel{\circ}{\circ}$ & 5 \\
\hline & 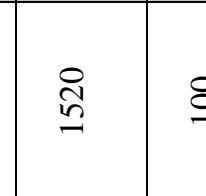 & 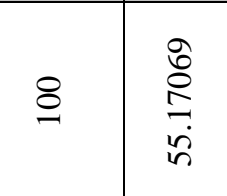 & 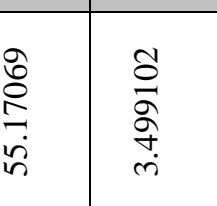 & 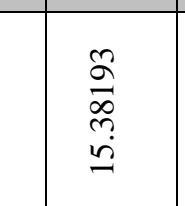 & 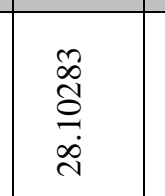 & 喿 & 善 & $\frac{8}{8}$ \\
\hline & 宰 & $\triangleq \quad$ & 量喜 & 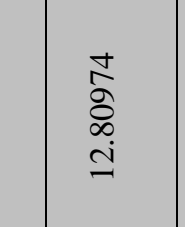 & 总 & 占 & 墁 & 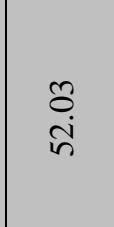 \\
\hline & : & $\cong$ & 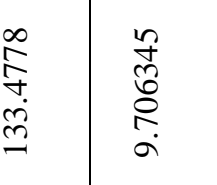 & 旁 & 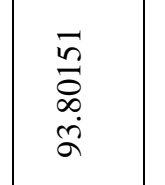 & 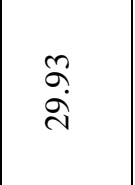 & 敦 & : \\
\hline & $\underline{\underline{\underline{Q}}}$ & $\cong \overline{\bar{z}}$ & 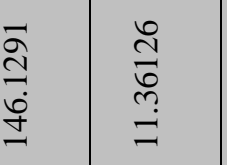 & 冨 & 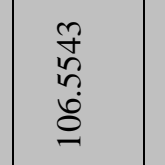 & 爱 & 总 & $\overline{\frac{\delta}{\partial}}$ \\
\hline & \begin{tabular}{|l|l}
$\mathscr{g}$ & $\Xi$
\end{tabular} & $\underline{\underline{z}}$ & $\frac{1}{8}$ & 彭 & 恙 & 尊 & 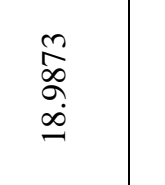 & $\frac{8}{5}$ \\
\hline & 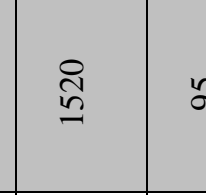 & $\begin{array}{ll}\circ \\
5\end{array}$ & $\begin{array}{l}0 \\
\frac{6}{2}\end{array}$ & 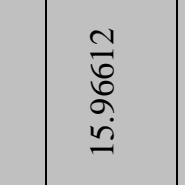 & 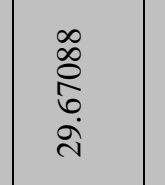 & \& & 产 & g \\
\hline & 号 & 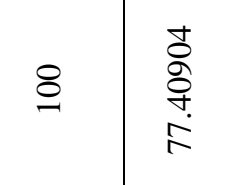 & 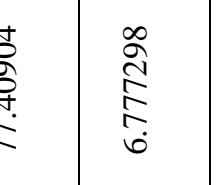 & 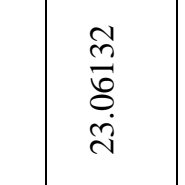 & \begin{tabular}{|l} 
总 \\
尊
\end{tabular} & $\mid \begin{array}{l}8 \\
\dddot{7}\end{array}$ & 曾 & $\frac{9}{*}$ \\
\hline & 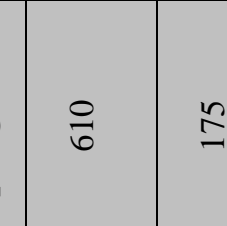 & $\cong \quad$ & 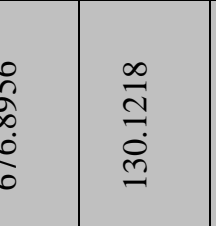 & 䔝 & 等 & $f^{7}$ & 善 & $T^{n}$ \\
\hline
\end{tabular}




\begin{tabular}{|c|c|c|c|c|c|c|c|c|c|}
\hline & 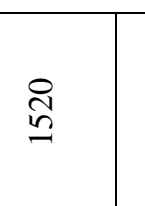 & $\stackrel{\underline{g}}{ }$ & 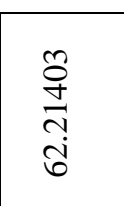 & 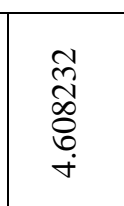 & 尌 & 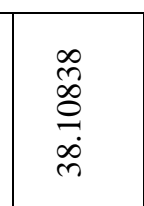 & 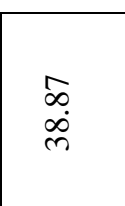 & 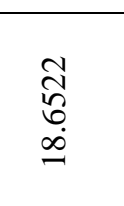 & ఫి \\
\hline & 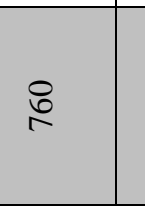 & $\underline{\underline{z}}$ & $\begin{array}{l}\frac{5}{5} \\
\frac{5}{7}\end{array}$ & $\begin{array}{l}\text { 坟 } \\
\text { to }\end{array}$ & 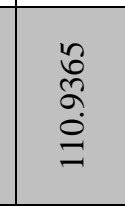 & 害 & 商 & 敦 & $\frac{8}{7}$ \\
\hline & $\frac{O}{j}$ & $\stackrel{n}{8}$ & 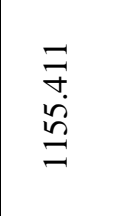 & 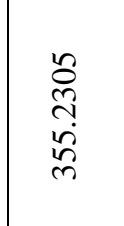 & 竒 & 量 & 啇 & 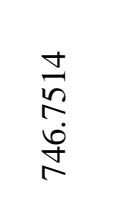 & $\frac{\infty}{\frac{\alpha}{\partial}}$ \\
\hline & ฐ & 8 & $\frac{2}{\frac{2}{2}}$ & 总 & 㙜 & 旁尊 & $\frac{\partial}{\partial}$ & 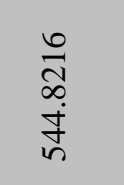 & 5 \\
\hline & $\stackrel{\varrho}{\varrho}$ & $\underline{\Omega}$ & 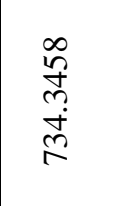 & $\begin{array}{l}\frac{\mathscr{\%}}{\sigma} \\
\frac{\partial}{\sigma}\end{array}$ & \begin{tabular}{|l}
$\overline{8}$ \\
$\bar{y}$
\end{tabular} & \begin{tabular}{|l}
$\frac{5}{2}$ \\
$\frac{a}{6}$
\end{tabular} & 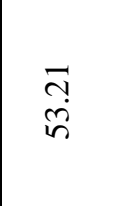 & 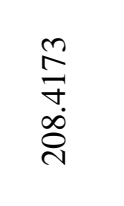 & $\frac{\mathscr{2}}{\partial}$ \\
\hline & 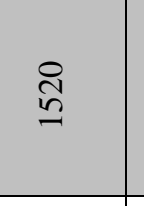 & 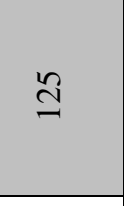 & 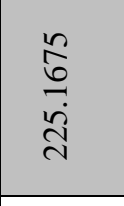 & $\begin{array}{l}\frac{n}{2} \\
\frac{2}{2} \\
\end{array}$ & 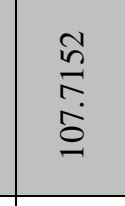 & $\begin{array}{l}\frac{-}{5} \\
\frac{5}{3}\end{array}$ & 今. & 愛 & : \\
\hline & $\stackrel{\varrho}{\varrho}$ & $\cong$ & 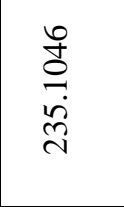 & 离 & $\begin{array}{l}\frac{0}{2} \\
\frac{i}{2}\end{array}$ & \begin{tabular}{|l}
$\frac{\underline{\underline{z}}}{\underline{\underline{z}}}$ \\
\end{tabular} & 㟦 & 嘸 & $\frac{\pi}{n}$ \\
\hline & 8 & 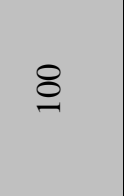 & 縞 & 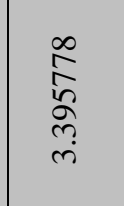 & 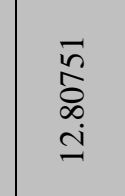 & 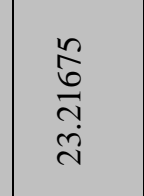 & $\overline{5}$ & 尊 & ซี \\
\hline & $\Xi$ & $\supseteqq$ & 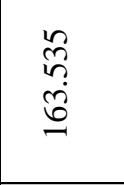 & $\stackrel{9}{\underline{9}}$ & 爱 & $\begin{array}{l}\text { 䱏 } \\
\end{array}$ & $\stackrel{\%}{q}$ & 曾 & 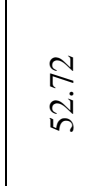 \\
\hline & $\underline{\underline{\underline{x}}}$ & $\underline{\underline{g}}$ & 縍 & 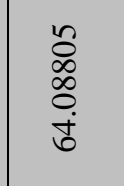 & 爱 & 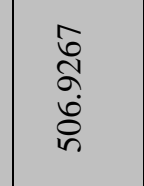 & $\frac{\mathscr{q}}{\dot{q}}$ & 善 & 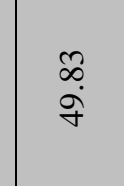 \\
\hline
\end{tabular}




\begin{tabular}{|c|c|c|c|c|c|c|c|c|c|}
\hline & 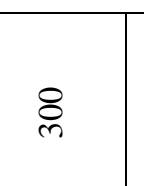 & $\underline{\underline{x}}$ & \begin{tabular}{|l|l|} 
\\
憘
\end{tabular} & 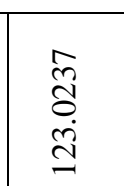 & $\frac{5}{2}$ & $\begin{array}{l}\frac{5}{8} \\
\end{array}$ & & 产 & \\
\hline & $\stackrel{\mathscr{g}}{\mathscr{g}}$ & $\stackrel{8}{a}$ & 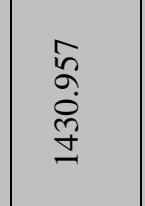 & 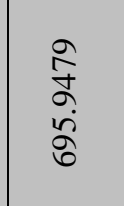 & 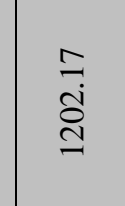 & 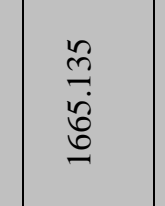 & $\frac{8}{2}$ & 憘 & gి \\
\hline & $\frac{2}{2}$ & $\underline{2}$ & 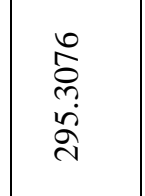 & 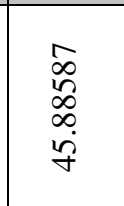 & \begin{tabular}{|l} 
\\
喜
\end{tabular} & 害 & 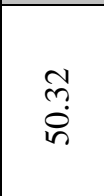 & 总 & 商 \\
\hline & 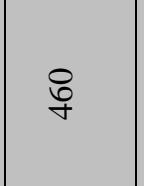 & $\cong$ & $\begin{array}{l}\text { 总 } \\
\underline{=}\end{array}$ & 竟 & 善 & 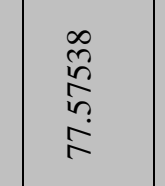 & $\frac{2}{n-2}$ & 善 & 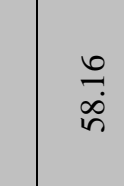 \\
\hline & $\underline{g}$ & $\stackrel{8}{\circ}$ & \begin{tabular}{|l} 
\\
豆 \\
\end{tabular} & 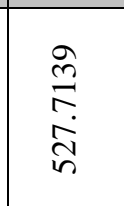 & 兴 & 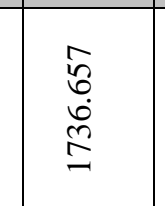 & $\infty$ & 总 & $\underset{⿱ 亠 ⿻}{q}$ \\
\hline & 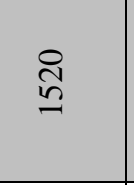 & s & $\mid \begin{array}{c}\frac{\mathrm{t}}{\mathrm{z}} \\
\mathrm{i}\end{array}$ & 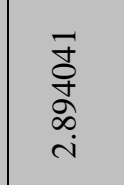 & 等 & \begin{tabular}{|l} 
总 \\
s.
\end{tabular} & $\frac{\mathscr{0}}{\tilde{\sigma}}$ & $\frac{8}{\partial}$ & 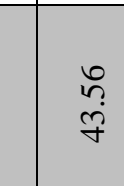 \\
\hline & 8 & $\dddot{x}$ & 嘉 & 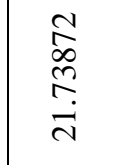 & 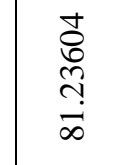 & 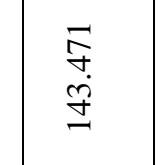 & 寿 & 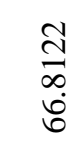 & 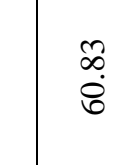 \\
\hline & 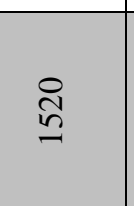 & $\cong$ & 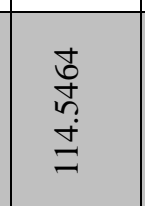 & 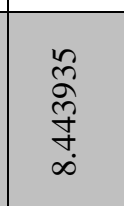 & \begin{tabular}{|l}
\multirow{2}{*}{$+\frac{8}{7}$} \\
\end{tabular} & 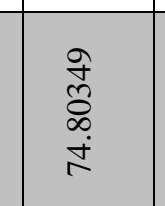 & $\frac{7}{q}$ & 旁 & 胥 \\
\hline & $\stackrel{g}{a}$ & $\cong$ & 兽 & 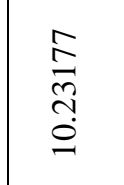 & 善 & 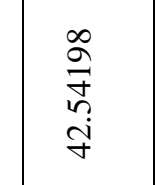 & 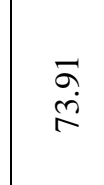 & 兴 & $\frac{8}{8}$ \\
\hline & 总 & 呈 & 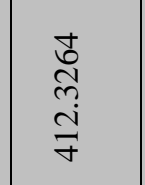 & 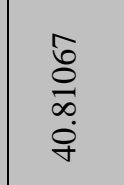 & 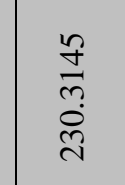 & \begin{tabular}{|l} 
高 \\
辛
\end{tabular} & $\bar{s}$ & 言 & 总 \\
\hline & & $\stackrel{?}{2}$ & & $\frac{\frac{g}{n}}{2}$ & 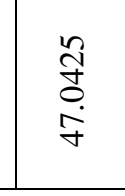 & \begin{tabular}{|l} 
䅭 \\
\end{tabular} & & & \\
\hline
\end{tabular}




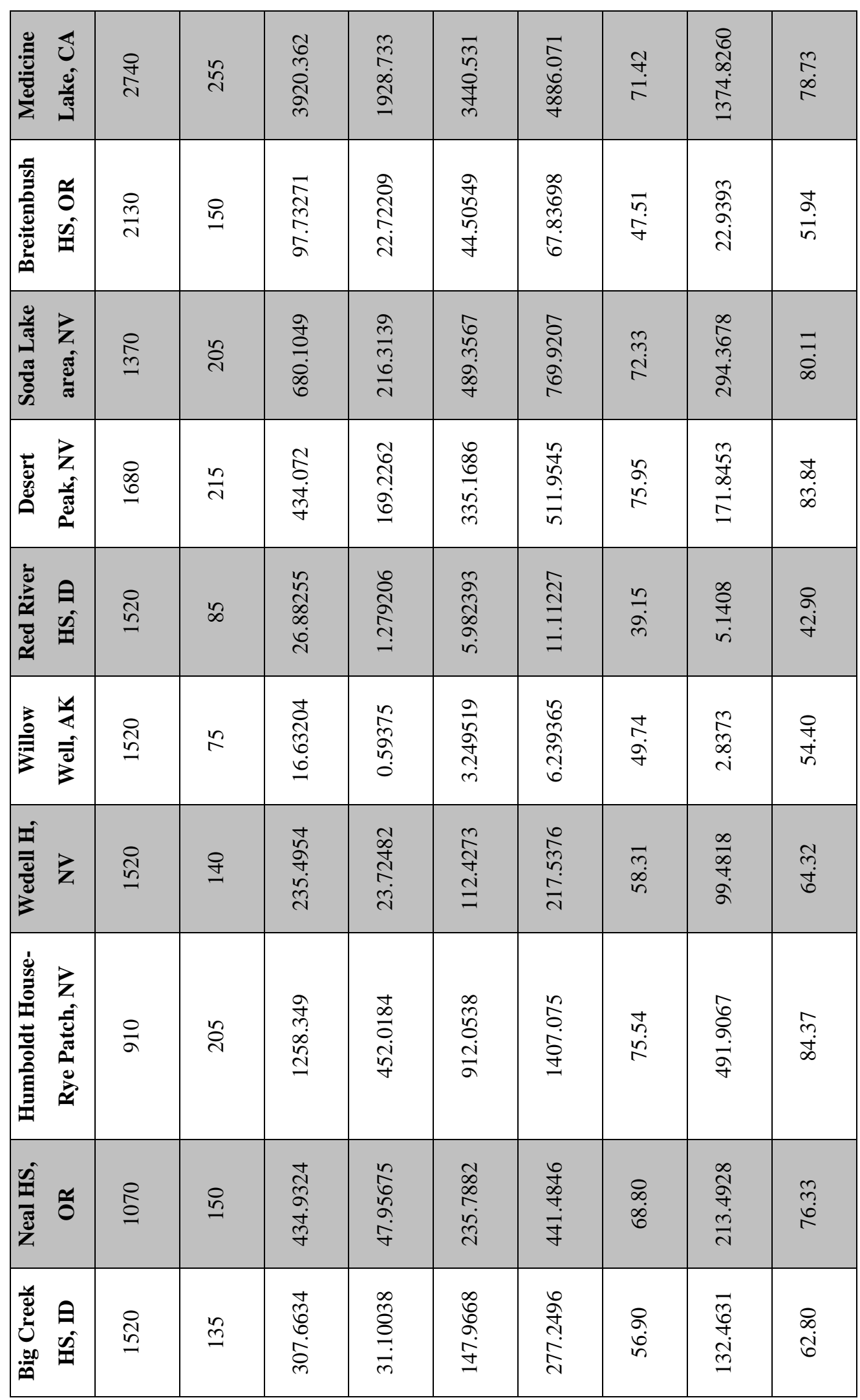




\begin{tabular}{|c|c|c|c|c|c|c|c|c|}
\hline & 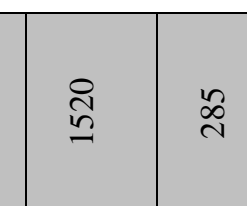 & 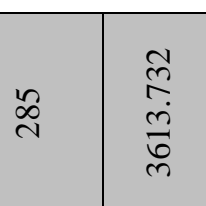 & 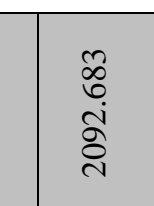 & \begin{tabular}{|l|}
2 \\
$\frac{2}{8}$
\end{tabular} & 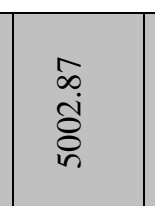 & $\overrightarrow{\bar{\alpha}}$ & & \\
\hline & $\cong$ & 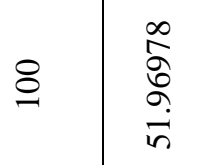 & 㕉 & 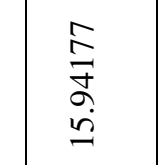 & 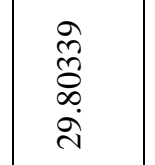 & 离 & 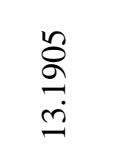 & : \\
\hline 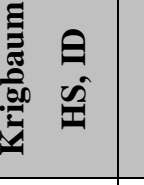 & : $:$ & : & 产 & 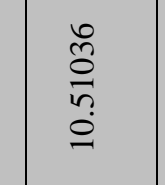 & 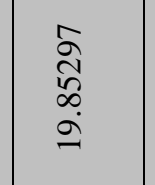 & $\stackrel{\%}{q}$ & 喜 & $\frac{a}{\vec{\alpha}}$ \\
\hline 4 & 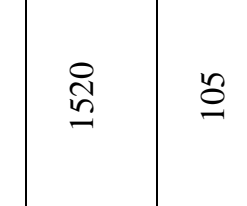 & 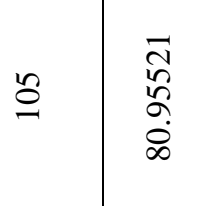 & 嘉 & 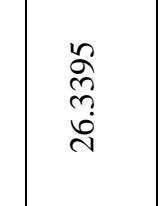 & 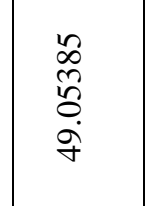 & 声 & 善 & \\
\hline 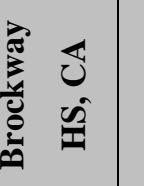 & : & : & 㩊 & 善 & 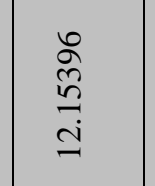 & $\mathscr{8}$ & 喜 & \\
\hline & $\dddot{\Xi}$ & פ & $\begin{array}{l}\text { 总 } \\
\text { 总 }\end{array}$ & 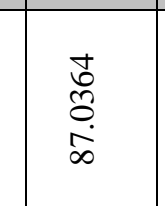 & 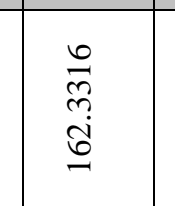 & 产 & 冞 & \\
\hline & $\cong$ & 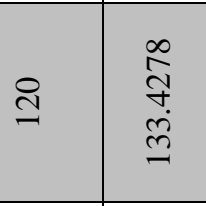 & 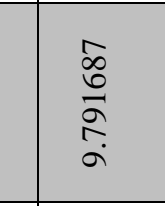 & 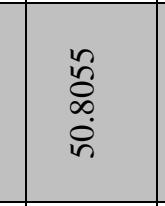 & 产 & $\frac{8}{8}$ & 鰥 & \\
\hline & \begin{tabular}{|l|l|}
$\check{g}$ & $\cong$
\end{tabular} & $\begin{array}{ll}2 \\
2\end{array}$ & 言 & 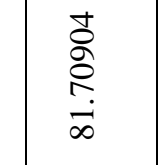 & 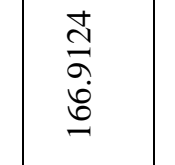 & $\stackrel{8}{\stackrel{8}{9}}$ & 鄯 & \\
\hline & 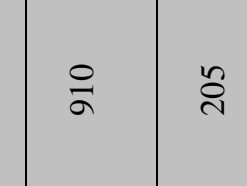 & 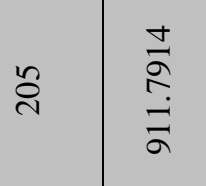 & $\frac{\mathbb{Z}}{\underline{z}}$ & 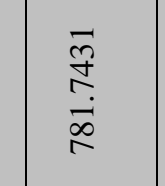 & 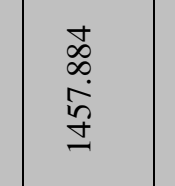 & $\bar{s}$ & 孰 & \\
\hline & 兽 & 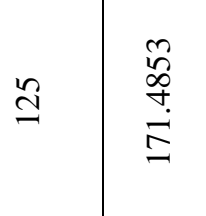 & $\stackrel{\check{g}}{2}$ & 剖 & 总 & 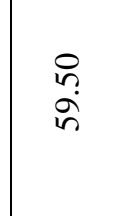 & & \\
\hline
\end{tabular}




\begin{tabular}{|c|c|c|c|c|c|c|c|c|c|}
\hline & 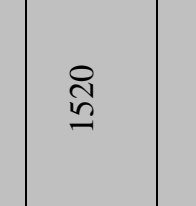 & s. & 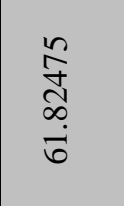 & 总 & \begin{tabular}{|l}
$\mathbf{8}$ \\
意 \\
$\underline{\underline{a}}$
\end{tabular} & 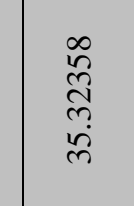 & 華 & 熟 & 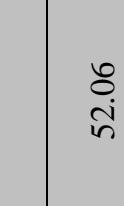 \\
\hline & 气气 & $\dddot{g}$ & 害 & 量 & $\begin{array}{l}\text { 歖 } \\
\text { the }\end{array}$ & $\begin{array}{l}\frac{n}{\grave{n}} \\
\text { â }\end{array}$ & $\stackrel{乛}{2}$ & 总 & 言 \\
\hline & 番 & $\nexists$ & 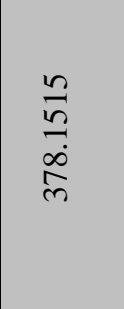 & 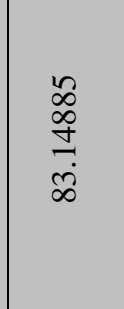 & 善 & $\begin{array}{l}\frac{9}{2} \\
\frac{8}{2}\end{array}$ & 美 & 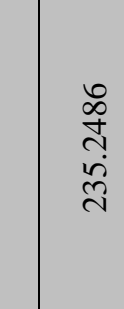 & 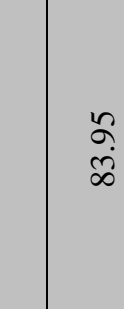 \\
\hline & $\dddot{g}$ & $\dddot{a}$ & 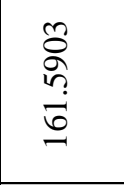 & 暜 & 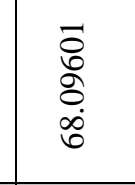 & 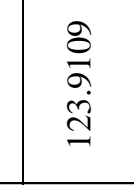 & $\overline{\bar{g}}$ & 善 & 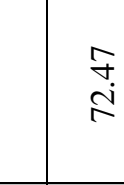 \\
\hline & $\cong$ & $\mathrm{s}$ & 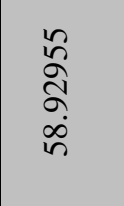 & 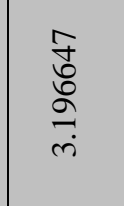 & 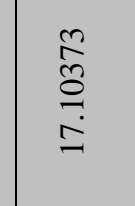 & \begin{tabular}{|l} 
螪 \\
\end{tabular} & 系 & $\begin{array}{l}\text { 罍 } \\
\end{array}$ & 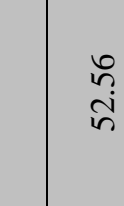 \\
\hline & ஜํ. & 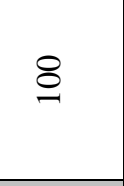 & 善 & 总 & 彦 & 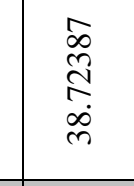 & $\overline{\bar{g}}$ & 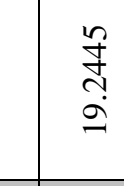 & 壱 \\
\hline & 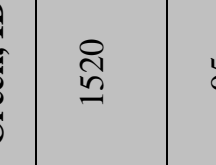 & s & 离 & $\begin{array}{l}\text { 洯 } \\
\text { | }\end{array}$ & 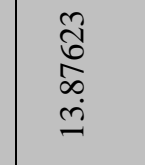 & 参 & శి & 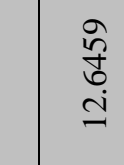 & مَ \\
\hline & $\check{\tilde{g}}$ & 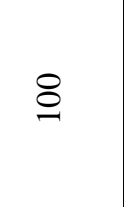 & " & 离 & 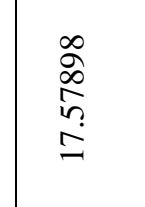 & $\frac{\frac{5}{8}}{3}$ & $\frac{\infty}{\partial}$ & 曾 & \\
\hline
\end{tabular}




\begin{tabular}{|c|c|c|c|c|c|c|c|c|c|}
\hline 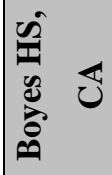 & त్ & $\stackrel{\varrho}{=}$ & $\frac{\infty}{\stackrel{\infty}{+}} \frac{0}{8}$ & 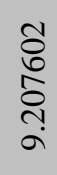 & $\begin{array}{l}\frac{n}{r} \\
\stackrel{\vec{g}}{\sigma}\end{array}$ & $\begin{array}{l}\mathfrak{2} \\
\frac{1}{6} \\
\infty \\
\infty\end{array}$ & 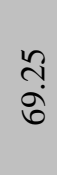 & 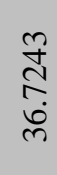 & ڤे \\
\hline 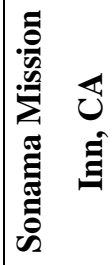 & 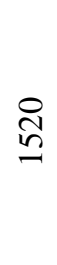 & $\stackrel{\varrho}{=}$ & 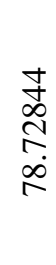 & 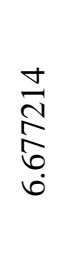 & 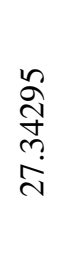 & 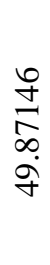 & $\begin{array}{l}\stackrel{\infty}{1} \\
\stackrel{b}{0}\end{array}$ & 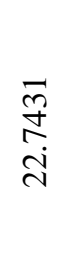 & ô \\
\hline 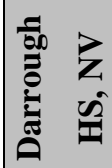 & $\frac{0}{6}$ & ్ㅗ & 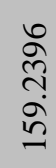 & $\begin{array}{l}\hat{\Delta} \\
\text { à } \\
\dot{\Xi}\end{array}$ & 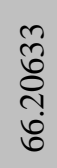 & $\begin{array}{l}0 \\
\infty \\
m \\
\\
\text { ñ }\end{array}$ & $\stackrel{n}{n}$ & $\underset{\stackrel{\tilde{I}}{I}}{\overrightarrow{\dot{H}}}$ & $\underset{\infty}{n}$ \\
\hline 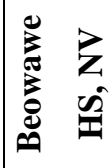 & $\underset{\sim}{\stackrel{+}{d}}$ & $\frac{n}{2}$ & $\begin{array}{l}\infty \\
\infty \\
\stackrel{m}{?} \\
\stackrel{0}{\circ}\end{array}$ & $\begin{array}{l}\bar{\delta} \\
\text { ర్ర } \\
\overline{\bar{v}}\end{array}$ & $\begin{array}{l}\frac{1}{2} \\
\text { ó } \\
\text { on } \\
\text { nn }\end{array}$ & 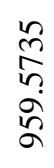 & 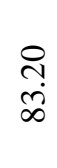 & $\begin{array}{l}\text { f } \\
\text { mे } \\
\infty \\
\infty \\
\infty\end{array}$ & $\stackrel{\infty}{\sigma}$ \\
\hline 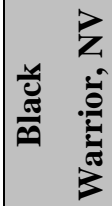 & ్ㅗ & $\stackrel{n}{n}$ & 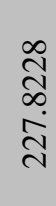 & $\begin{array}{l}\vec{\alpha} \\
\stackrel{0}{0} \\
\stackrel{\sim}{+} \\
\dot{N}\end{array}$ & $\begin{array}{l}+ \\
\& \\
\stackrel{\infty}{+} \\
\dot{0} \\
0\end{array}$ & $\begin{array}{l}\stackrel{+}{0} \\
\stackrel{0}{0} \\
\dot{0} \\
\stackrel{0}{0}\end{array}$ & $\stackrel{\infty}{\underset{+}{+}}$ & $\begin{array}{l}\overline{\hat{O}} \\
\bar{\alpha} \\
\text { à }\end{array}$ & $\underset{\infty}{\vec{d}}$ \\
\hline 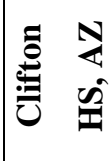 & ิㅗ & $\stackrel{\varrho}{=}$ & 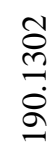 & 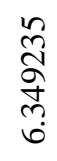 & $\begin{array}{l}\infty \\
8 \\
\infty \\
\infty \\
\infty \\
\infty\end{array}$ & 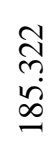 & $\begin{array}{l}\stackrel{2}{+} \\
\stackrel{q}{q}\end{array}$ & $\begin{array}{l}8 \\
\infty \\
\dddot{0} \\
8 \\
8\end{array}$ & $\begin{array}{l}\tilde{D} \\
\dot{H}\end{array}$ \\
\hline 苞 & 8 & $\approx$ & 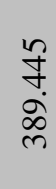 & 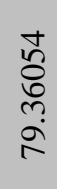 & $\begin{array}{l}\hat{\circ} \\
\stackrel{2}{2} \\
\dot{0} \\
\stackrel{1}{0}\end{array}$ & $\begin{array}{l}\tilde{\delta} \\
\tilde{n} \\
\tilde{n} \\
n\end{array}$ & 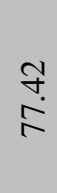 & $\begin{array}{l}\text { वे } \\
\text { ర్ } \\
\dot{ \pm}\end{array}$ & $\underset{\infty}{\infty}$ \\
\hline 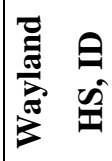 & $\underset{\infty}{\infty}$ & $\stackrel{\text { }}{-1}$ & $\begin{array}{l}n \\
\infty \\
\delta \\
\dot{\infty} \\
\infty\end{array}$ & 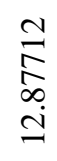 & \begin{tabular}{l}
$\infty$ \\
\multirow{N}{n}{} \\
$\infty$ \\
$\infty$ \\
$\infty$
\end{tabular} & 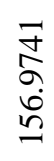 & $\begin{array}{l}\infty \\
\dot{q} \\
\dot{q}\end{array}$ & $\begin{array}{l}\infty \\
\infty \\
\stackrel{0}{+} \\
\stackrel{\nabla}{\gamma}\end{array}$ & $\begin{array}{l}\stackrel{+}{+} \\
\stackrel{+}{n}\end{array}$ \\
\hline 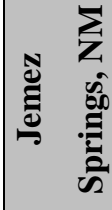 & ్ㅗ & $\stackrel{\varrho}{ }$ & $\begin{array}{l}2 \\
\text { in } \\
\text { n. } \\
=\end{array}$ & $\begin{array}{c}\mathcal{T} \\
\tilde{\sigma} \\
\tilde{ల} \\
\infty \\
\infty\end{array}$ & $\begin{array}{l}\hat{0} \\
\infty \\
o \\
+ \\
\dot{\gamma}\end{array}$ & $\begin{array}{l}\infty \\
0 \\
8 \\
0 \\
n \\
2 \\
1\end{array}$ & $\underset{\infty}{\infty}$ & & $\underset{0}{\stackrel{0}{\infty}}$ \\
\hline 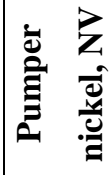 & ิㅗㄱ & $\stackrel{\varrho}{\cong}$ & $\begin{array}{l}\stackrel{2}{2} \\
\dot{+} \\
\dot{0}\end{array}$ & $\begin{array}{l}2 \\
\infty \\
\infty \\
\infty \\
\stackrel{J}{~}\end{array}$ & \begin{tabular}{l}
$\stackrel{0}{n}$ \\
$i n$ \\
\multirow{2}{*}{} \\
$\infty$ \\
$n$
\end{tabular} & $\begin{array}{l}\underset{\Xi}{\infty} \\
\infty \\
\stackrel{0}{0}\end{array}$ & $\stackrel{0}{\longrightarrow}$ & $\frac{8}{8}$ & $\begin{array}{l}\bar{\sigma} \\
\infty \\
\infty\end{array}$ \\
\hline
\end{tabular}




\begin{tabular}{|c|c|c|c|c|c|c|c|c|}
\hline & 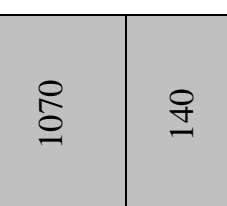 & 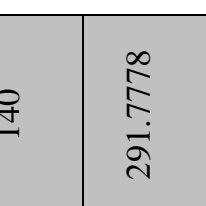 & 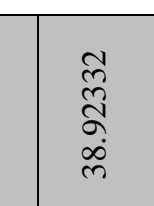 & 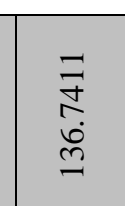 & 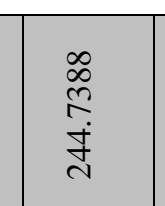 & $\bar{z}$ & 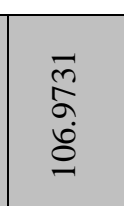 & \\
\hline & $\stackrel{\square}{\square}$ & 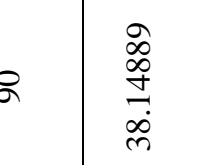 & 商 & 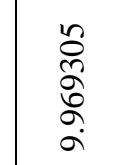 & 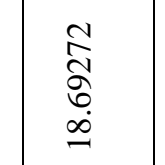 & $\frac{n}{n}$ & 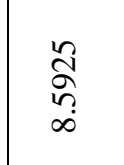 & \\
\hline & $\cong$ & 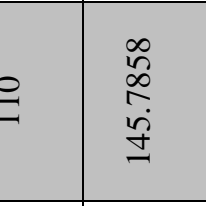 & 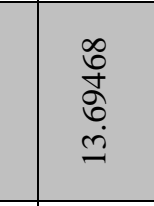 & 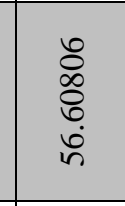 & 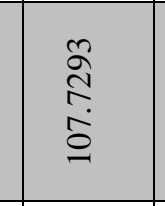 & $\frac{\sigma}{*}$ & 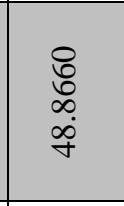 & \\
\hline & $\stackrel{g}{\Xi}$ & 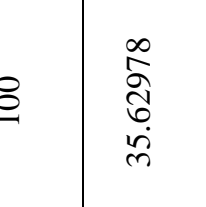 & 善 & 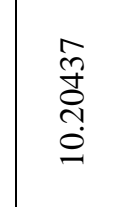 & 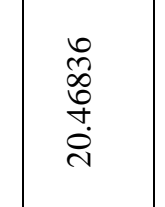 & 总 & 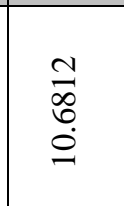 & $\begin{array}{l}q_{\infty}^{8} \\
\infty\end{array}$ \\
\hline & $\cong$ & $=$ = 憘 & 产 & $\frac{2}{2}$ & 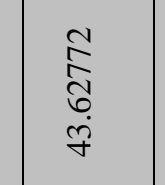 & $\frac{\pi}{8}$ & 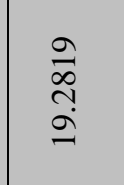 & $g$ \\
\hline & $\stackrel{\square}{g}$ & 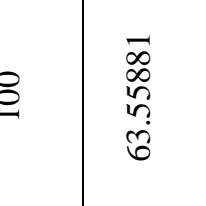 & 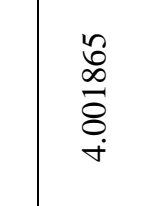 & 釬 & 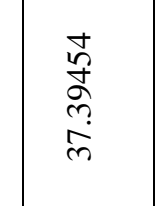 & 縞 & 总 & \\
\hline & $\stackrel{\underline{\underline{\underline{x}}}}{\varrho}$ & 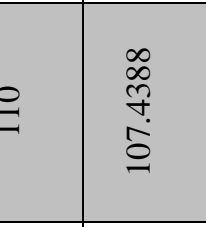 & 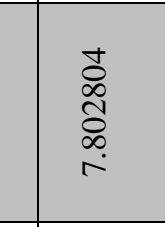 & $\frac{5}{5}$ & \begin{tabular}{|l|}
$\frac{\infty}{\mathbf{x}_{3}}$ \\
\end{tabular} & $\frac{8}{\partial}$ & 总 & 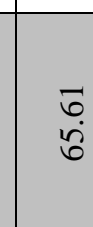 \\
\hline & $\stackrel{\square}{9}$ & 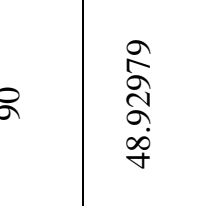 & 莃 & 墨 & 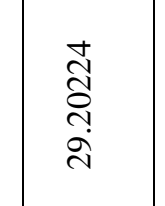 & 喜 & $\begin{array}{l}\frac{O}{\bar{z}} \\
\frac{a}{a}\end{array}$ & \\
\hline & פ & $=\frac{\stackrel{o}{\bar{\partial}}}{\underline{\underline{\partial}}}$ & . & m & \begin{tabular}{|l|l}
$\frac{\infty}{\mathrm{g}}$ \\
$\mathrm{g}$ \\
$\mathrm{g}$
\end{tabular} & $r$ & 就 & \\
\hline & \begin{tabular}{l|l}
$\stackrel{g}{g}$ \\
\end{tabular} & 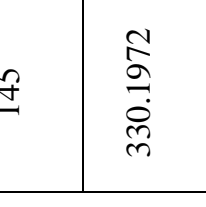 & & & 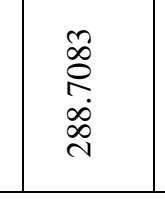 & & 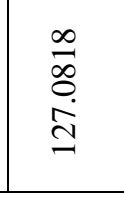 & \\
\hline
\end{tabular}




\begin{tabular}{|c|c|c|c|c|c|c|c|c|c|}
\hline$\underline{x}$ & $\ddot{g}$ & $\cong$ & 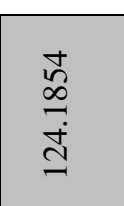 & 蔏 & 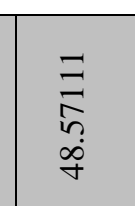 & \begin{tabular}{|l|l}
\multicolumn{2}{c}{} \\
s. \\
s.
\end{tabular} & 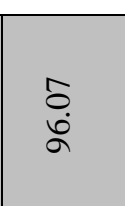 & 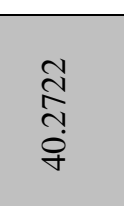 & 总 \\
\hline & ฐి & $\cong$ & 唁 & 囍 & 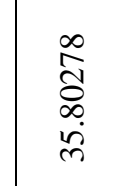 & 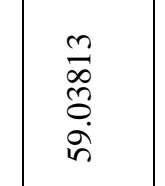 & 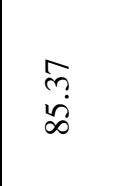 & 踦 & 采 \\
\hline & 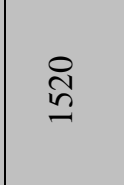 & 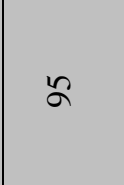 & 嘉 & 管 & 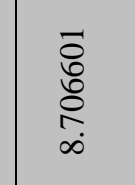 & 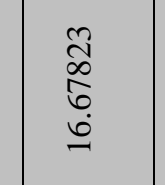 & 喜 & 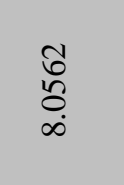 & : \\
\hline & $\check{g}$ & $\cong$ & 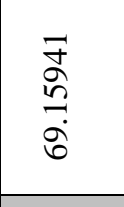 & 喜 & 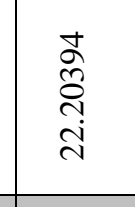 & 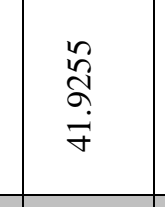 & 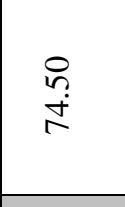 & $\begin{array}{l}\frac{\infty}{0} \\
\frac{\mathrm{g}}{\mathrm{g}}\end{array}$ & 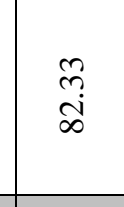 \\
\hline & $\check{g}$ & $\cong$ & 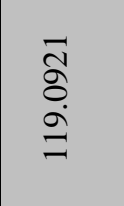 & 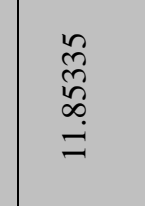 & 絭 & 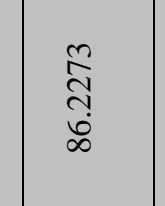 & 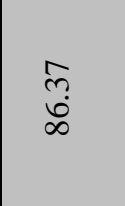 & $\frac{\frac{\partial}{\partial}}{\partial}$ & 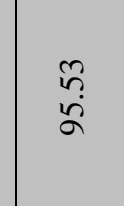 \\
\hline 童 & $\check{g}$ & $\therefore$ & 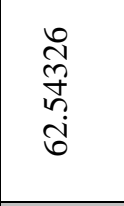 & 喜 & \begin{tabular}{|l} 
\\
童 \\
|
\end{tabular} & 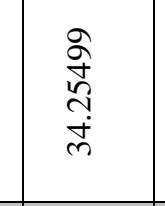 & 装 & $\begin{array}{l}\text { gू } \\
\stackrel{2}{6}\end{array}$ & : \\
\hline & $\stackrel{\check{g}}{\underline{9}}$ & $\cong$ & 尊 & 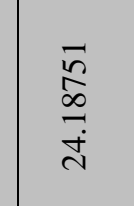 & 嘉 & 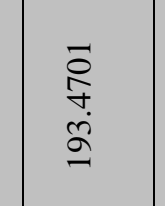 & 佘 & 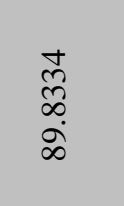 & 兽 \\
\hline & 卓 & $\cong$ & 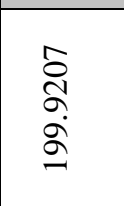 & 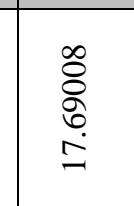 & 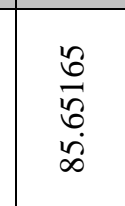 & 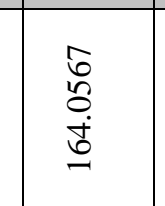 & $\stackrel{\pi}{\pi}$ & 总 & 高 \\
\hline & 总 & $\stackrel{\varrho}{\varrho}$ & 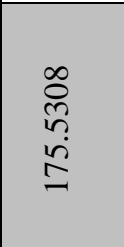 & 歖 & 暿 & 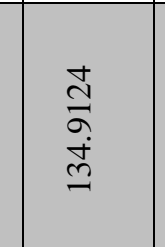 & 产 & 㩊 & $\frac{5}{5}$ \\
\hline 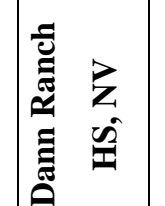 & $\sqrt{\mathscr{g}}$ & - & $\therefore$ & $\stackrel{x}{\underline{x}}$ & $\underline{n}$ & 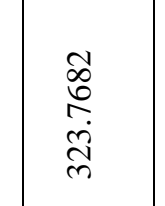 & $\bar{z}$ & 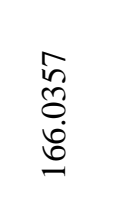 & 咅 \\
\hline
\end{tabular}




\begin{tabular}{|c|c|c|c|c|c|c|c|c|c|}
\hline & 竞 & $\cong$ & 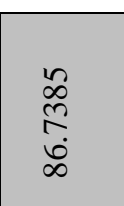 & 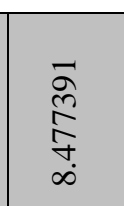 & 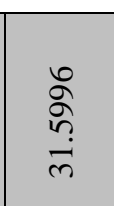 & 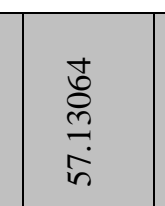 & है & $\frac{5}{\frac{5}{2}}$ & 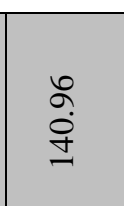 \\
\hline & 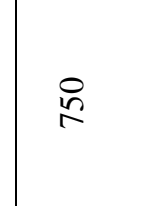 & 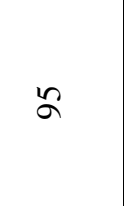 & 嬉 & 寒 & \begin{tabular}{|l} 
\\
善 \\
\end{tabular} & $\frac{2}{2}$ & 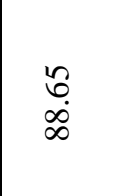 & 高 & $\bar{\Sigma}$ \\
\hline & ஜ̊ & $\Xi$ & 量 & 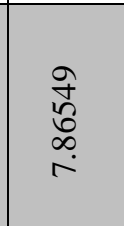 & 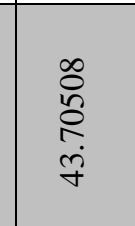 & $\frac{\ddot{z}}{\bar{z}}$ & 舀 & 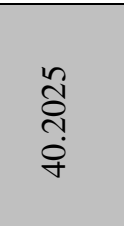 & 高 \\
\hline & $\stackrel{\check{g}}{\underline{g}}$ & $\cong$ & 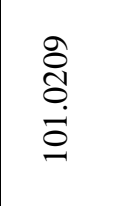 & $\begin{array}{l}\frac{\alpha}{2} \\
\frac{6}{2}\end{array}$ & 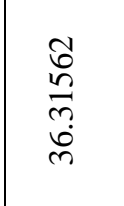 & \begin{tabular}{|l}
$\overline{\mathrm{V}}$ \\
$\mathrm{v}$ \\
$\mathrm{g}$
\end{tabular} & 告 & 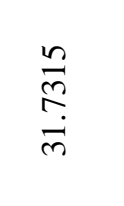 & के \\
\hline & 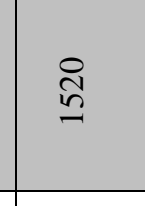 & $\cong$ & 总 & $\begin{array}{r}\text { 蒿 } \\
\end{array}$ & $\begin{array}{l}\text { 总 } \\
\text { ఫे } \\
\end{array}$ & 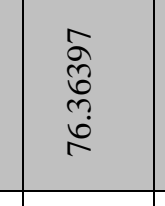 & ڤ. & 总 & 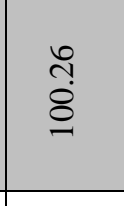 \\
\hline & $\stackrel{\Xi}{g}$ & $\cong$ & 畨 & 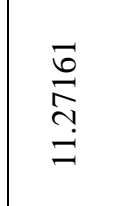 & 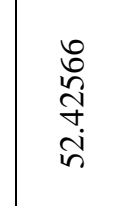 & 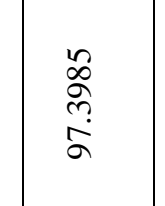 & 高 & 辤 & 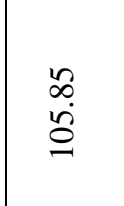 \\
\hline & 爰 & $\Xi$ & $\frac{\frac{2}{2}}{\frac{2}{2}}$ & 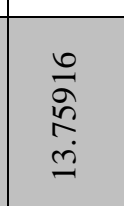 & 亳 & 等 & $\frac{2}{5}$ & 繂 & 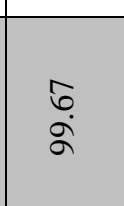 \\
\hline & $\stackrel{\Omega}{9}$ & $\cong$ & 樀 & 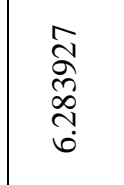 & 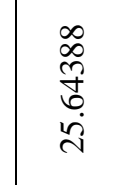 & 喜 & $\overline{\mathrm{g}}$ & 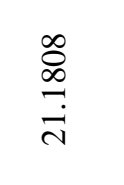 & $\frac{\partial}{\frac{2}{3}}$ \\
\hline 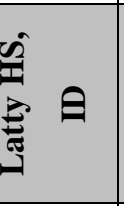 & g & $\cong$ & $\begin{array}{l}\text { 总 } \\
\text { : }\end{array}$ & 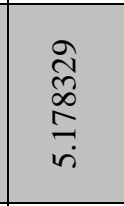 & 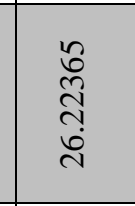 & 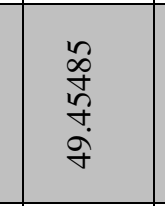 & 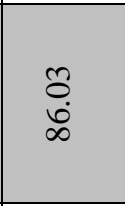 & 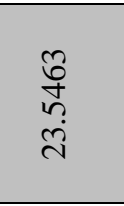 & 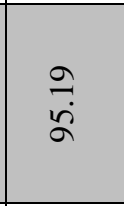 \\
\hline & 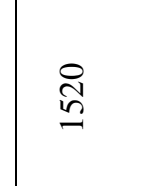 & $\cong$ & 品 & 总 & \begin{tabular}{|l} 
\\
\\
\end{tabular} & 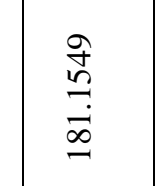 & 驾 & 圣 & 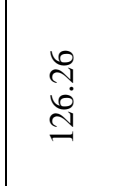 \\
\hline
\end{tabular}




\begin{tabular}{|c|c|c|c|c|c|c|c|c|c|}
\hline & ğ & $\cong$ & 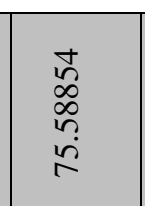 & 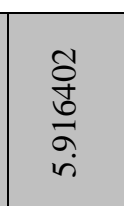 & 产 & 譬 & $\frac{\infty}{\alpha}$ & 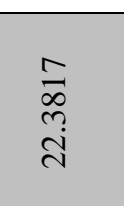 & \\
\hline & $\check{g}$ & $\underline{8}$ & 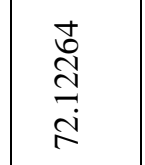 & 咅 & 嘉 & 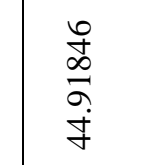 & $\frac{\mathscr{g}}{\mathrm{g}}$ & 量 & $g$ \\
\hline & 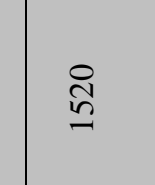 & : & 总 & 䜌 & 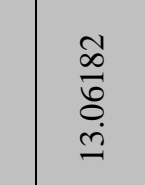 & \begin{tabular}{|l}
$\frac{8}{2}$ \\
$\frac{g}{3}$
\end{tabular} & $\stackrel{\mathrm{E}}{\mathrm{E}}$ & 言 & \\
\hline & $\bar{\Omega}$ & $\cong$ & 善 & 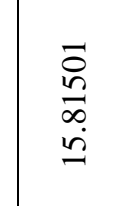 & 善 & 总 & $\overline{\mathrm{E}}$ & 譥 & $\frac{\mathscr{z}}{\tilde{z}}$ \\
\hline & Ø̊ & $\cong$ & 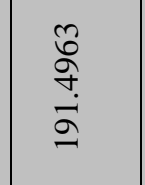 & 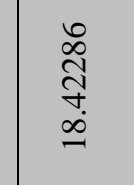 & 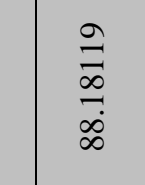 & 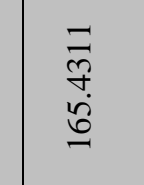 & $\frac{.}{2}$ & $\frac{\infty}{\frac{\alpha}{2}}$ & 5 \\
\hline & $\approx$ & $\stackrel{8}{8}$ & \begin{tabular}{|l}
$\frac{2}{2}$ \\
$\frac{2}{3}$ \\
$\frac{3}{2}$
\end{tabular} & 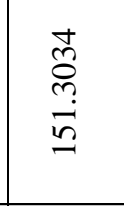 & $\begin{array}{l}\frac{2}{8} \\
\frac{1}{3}\end{array}$ & 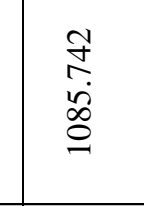 & 总 & $\begin{array}{l}\text { 愛 } \\
\text { 妾 }\end{array}$ & $=$ \\
\hline & $\ddot{g}$ & $\fallingdotseq$ & $\begin{array}{l}\text { 善 } \\
\text { s. }\end{array}$ & 薏 & 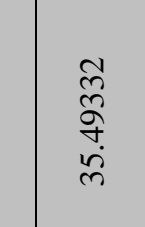 & 总 & $\overrightarrow{\mathrm{g}}$ & 善 & $\frac{.}{x_{x}}$ \\
\hline & 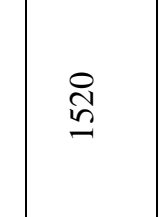 & $\underline{8}$ & 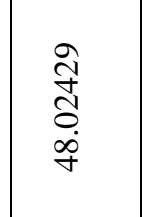 & 离 & 獣 & 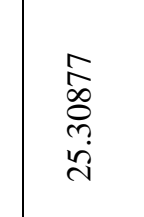 & $\frac{q^{\prime}}{\alpha}$ & 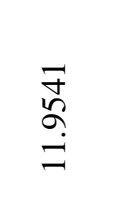 & \\
\hline & $\cong$ & $\cong$ & 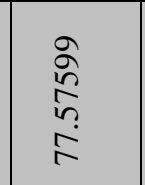 & 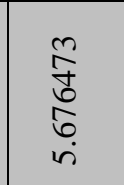 & \begin{tabular}{|l} 
\\
嘉
\end{tabular} & 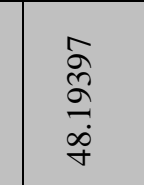 & 蛋 & 簽 & \\
\hline & & 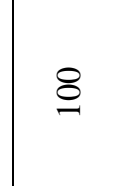 & 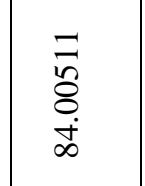 & 喜 & 18 & 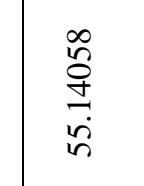 & $\mathscr{Z}$ & 善 & \\
\hline
\end{tabular}




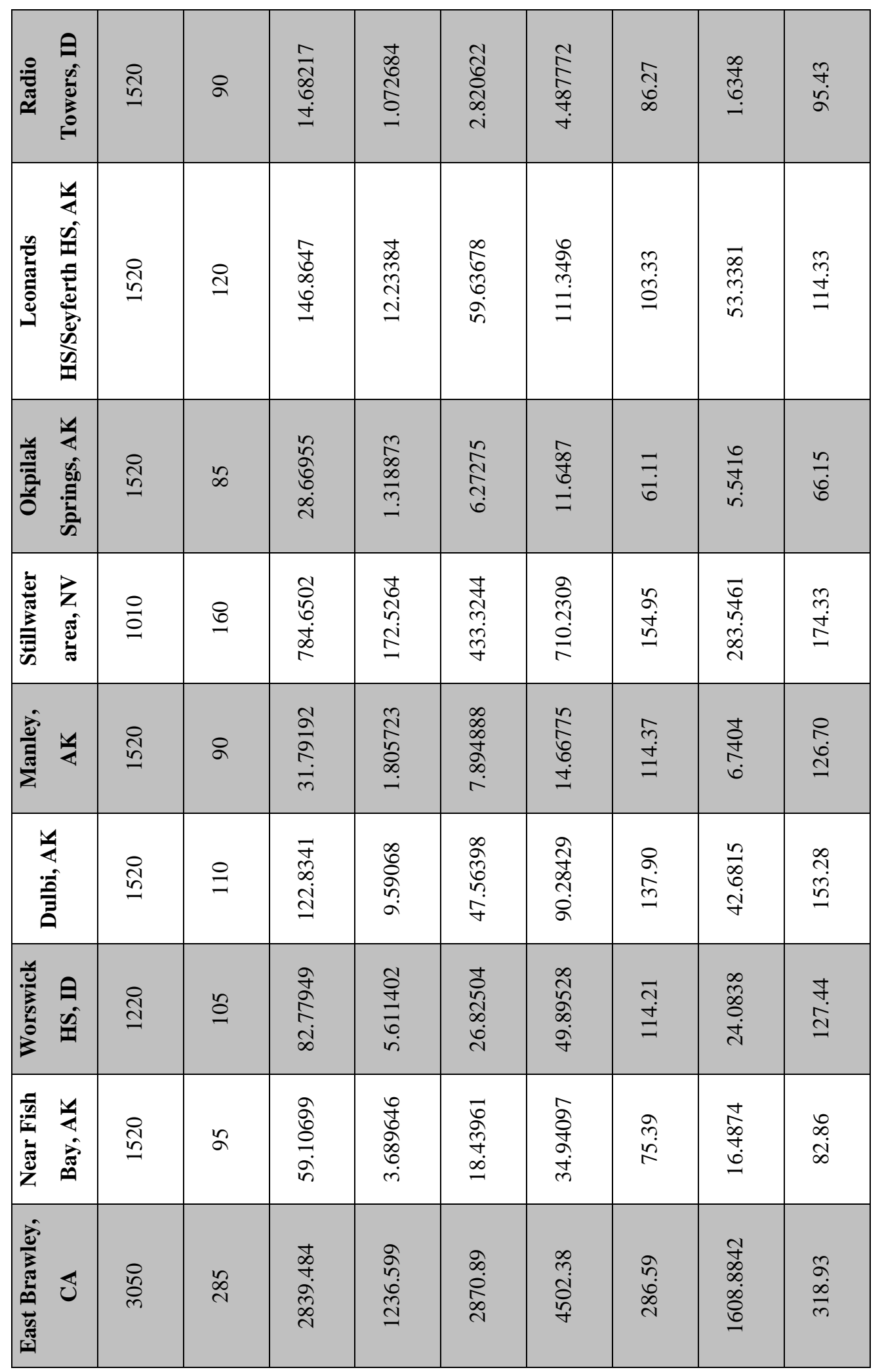




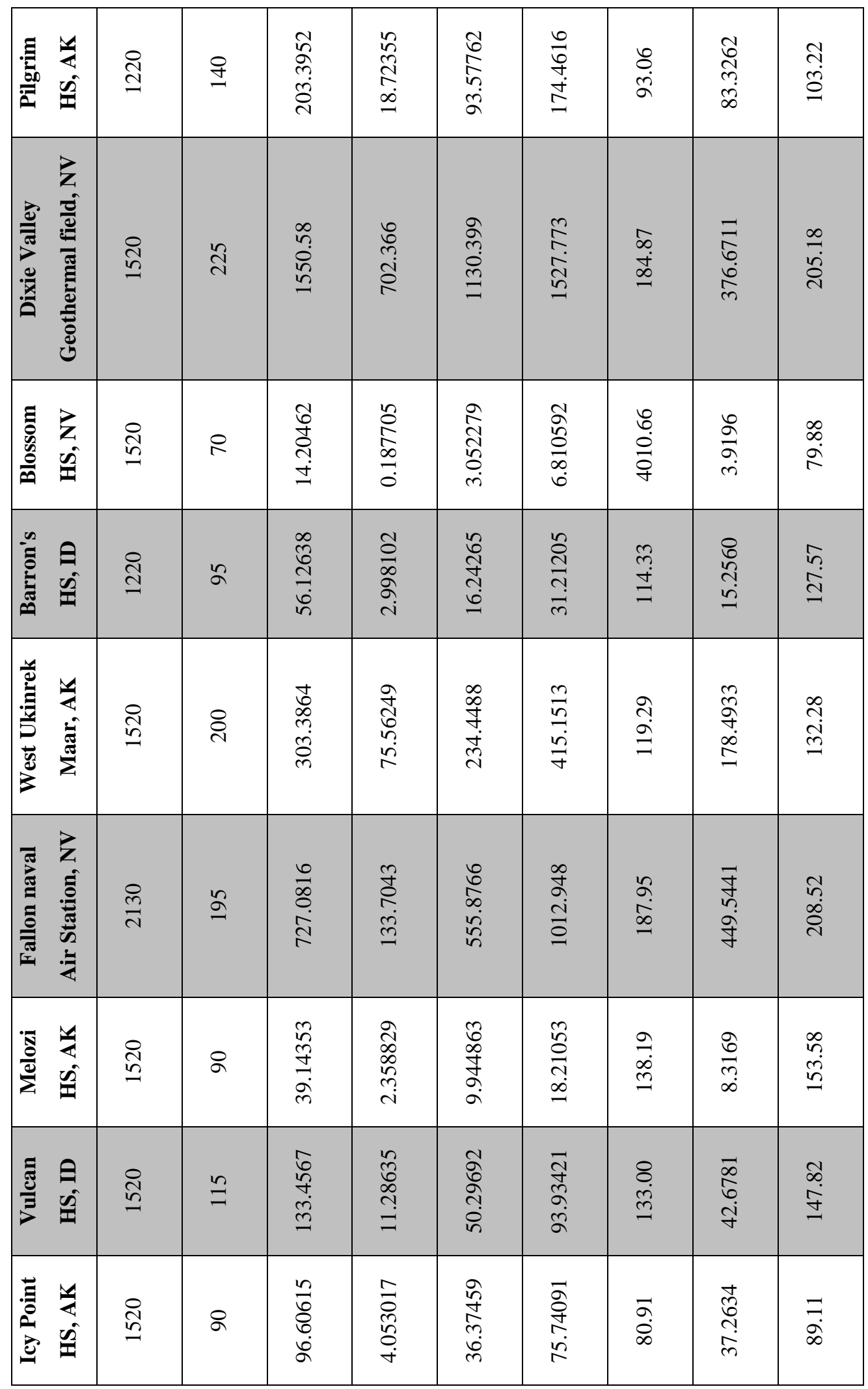




\begin{tabular}{|c|c|c|c|c|c|c|c|c|c|}
\hline & $\bar{g}$ & $\Xi$ & $\bar{y}$ & 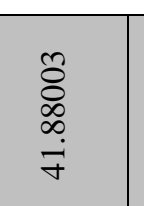 & \begin{tabular}{|l|}
$\underline{\underline{z}}$ \\
$\underline{z}$
\end{tabular} & 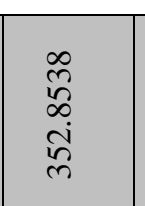 & 跣 & 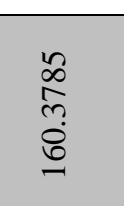 & $\frac{\circ}{\sigma}$ \\
\hline & $\mathscr{q}$ & $\underline{\underline{z}}$ & 总 & 嘉 & $\mid$ & $\mid$ & 要 & 爰 & $\frac{1}{\geq}$ \\
\hline & $\overline{\mathscr{g}}$ & $\cong$ & 善 & 旁 & 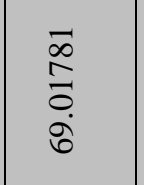 & 总 & 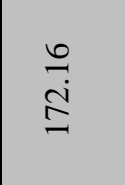 & 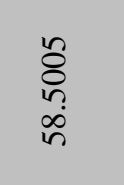 & $\frac{\alpha}{\alpha} \frac{\alpha}{\alpha}$ \\
\hline & $\stackrel{\square}{g}$ & $\underline{\underline{\underline{p}}}$ & 背 & 㩊 & 産 & 苞 & $\frac{t}{\delta}$ & 咅 & 善 \\
\hline & $\bar{g}$ & $\underline{\Xi}$ & 喜 & 罯 & 总 & 善 & 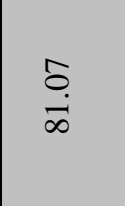 & 总 & \% \\
\hline & 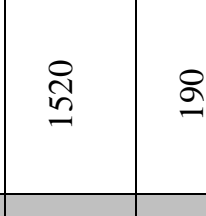 & $\cong$ & 䜌 & 喜 & 缶 & 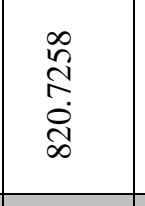 & 善 & $\begin{array}{l}\text { 高 } \\
\text { s. } \\
\text { a }\end{array}$ & 离 \\
\hline & $\cong$ & $\underline{8}$ & 善 & 蟑 & 喜 & 喜 & 素 & 参 & 兽 \\
\hline & 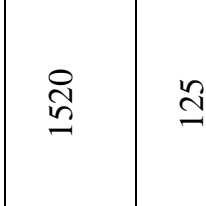 & $\cong$ & 歚 & 善 & 量 & $\begin{array}{l}\text { : } \\
\text { : } \\
\text { d. }\end{array}$ & $\stackrel{\infty}{\Xi}$ & 总 & $\frac{2}{\partial}$ \\
\hline & $\check{g}$ & $\S$ & 善 & 高 & $\frac{\frac{\partial}{2}}{\frac{\partial}{\alpha}}$ & $\begin{array}{l}\text { 总 } \\
\frac{6}{7}\end{array}$ & $\overline{\underline{\underline{\beta}}}$ & 兽 & $\approx$ \\
\hline & $\stackrel{\square}{g}$ & $\stackrel{\underline{s}}{\underline{s}}$ & 歚 & 繂 & 童 & & & - & \\
\hline
\end{tabular}




\begin{tabular}{|c|c|c|c|c|c|c|c|c|c|}
\hline 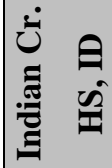 & ్ㅗ & $\curvearrowleft$ & $\frac{\sqrt{6}}{\sqrt{6}}$ & 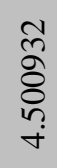 & $\begin{array}{l}\text { oे } \\
\text { +े } \\
\stackrel{+}{+}\end{array}$ & \begin{tabular}{l}
$\stackrel{0}{N}$ \\
\multirow{n}{n}{} \\
\multirow{\gamma}{*}{}
\end{tabular} & $\begin{array}{l} \pm \\
\ddot{m}\end{array}$ & $\begin{array}{l}\overline{0} \\
\stackrel{\circ}{+} \\
\text { ì }\end{array}$ & \begin{tabular}{l}
$\curvearrowleft$ \\
\multirow{J}{\pm}{}
\end{tabular} \\
\hline 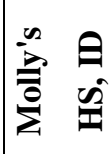 & ్ㅗ & $n$ & 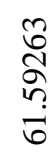 & $\begin{array}{l}\bar{b} \\
\delta \\
n \\
n \\
n \\
n\end{array}$ & $\begin{array}{l}\bar{n} \\
\tilde{0} \\
\infty \\
\infty\end{array}$ & 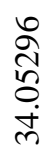 & $\begin{array}{l}\bar{D} \\
\ddot{n}\end{array}$ & $\frac{\hat{\sigma}}{\stackrel{\sigma}{\sigma}}$ & $\begin{array}{l}\stackrel{2}{+} \\
\end{array}$ \\
\hline 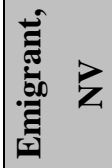 & $\underset{d}{\stackrel{+}{d}}$ & 6 & $\frac{\hat{\sigma}}{\hat{\sigma}}$ & 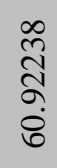 & 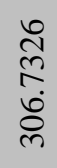 & $\underset{\substack{+\infty \\
\infty}}{\infty}$ & 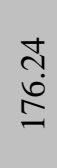 & 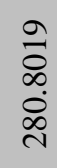 & $\begin{array}{l}\hat{\sigma} \\
\ddot{2} \\
\Omega\end{array}$ \\
\hline 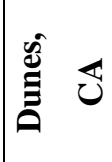 & $\stackrel{?}{0}$ & $\stackrel{n}{ \pm}$ & $\begin{array}{l}n \\
n \\
i \\
i \\
n \\
n\end{array}$ & 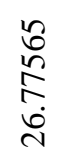 & $\begin{array}{l}\hat{\sigma} \\
\hat{\mathfrak{d}} \\
\end{array}$ & $\begin{array}{l}\stackrel{N}{t} \\
\delta \\
\dot{g} \\
\stackrel{d}{d}\end{array}$ & $\begin{array}{l}0 \\
\text { n. } \\
\infty \\
\infty \\
\infty\end{array}$ & $\begin{array}{l}\underset{g}{\partial} \\
\stackrel{g}{=}\end{array}$ & $\begin{array}{l}n \\
\dot{b} \\
\dot{0} \\
\tilde{m}\end{array}$ \\
\hline 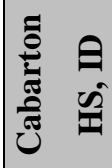 & त् & $\infty$ & 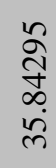 & $\begin{array}{l}\vec{\infty} \\
\infty \\
\infty \\
\stackrel{r}{-}\end{array}$ & $\begin{array}{l}\hat{\curvearrowright} \\
\hat{n} \\
\hat{\alpha} \\
\infty\end{array}$ & $\begin{array}{l}8 \\
8 \\
8 \\
8 \\
1\end{array}$ & $\begin{array}{l}\hat{m} \\
\tilde{m}\end{array}$ & $\begin{array}{l}\infty \\
0 \\
0 \\
\end{array}$ & $\stackrel{9}{\infty}$ \\
\hline 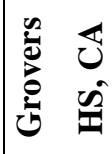 & ్ㅗ & \& & 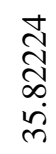 & 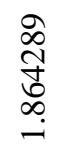 & $\begin{array}{l}i n \\
\vdots \\
0 \\
0\end{array}$ & $\begin{array}{l}\infty \\
\infty \\
2 \\
\wp \\
\infty \\
\infty\end{array}$ & $\begin{array}{l}\mathscr{n} \\
\dot{m} \\
\dot{\sigma}\end{array}$ & \begin{tabular}{l}
$\stackrel{r}{o}$ \\
$\stackrel{m}{f}$ \\
\multirow{\sigma}{a}{}
\end{tabular} & \\
\hline 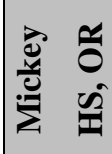 & $\stackrel{?}{0}$ & 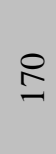 & $\begin{array}{l}8 \\
\delta \\
\vdots \\
\hat{n} \\
i\end{array}$ & 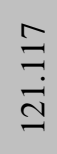 & 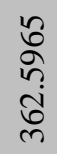 & 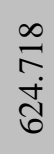 & $\frac{0}{\stackrel{0}{\pi}}$ & $\begin{array}{l}n \\
8 \\
0 \\
\dot{8} \\
\text { iे }\end{array}$ & $\begin{array}{l}\infty \\
\vdots \\
n \\
n \\
n\end{array}$ \\
\hline 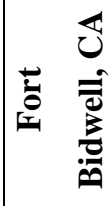 & $\stackrel{8}{\circ}$ & $\stackrel{\varrho}{=}$ & 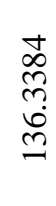 & $\begin{array}{l}\hat{\sigma} \\
\stackrel{2}{a} \\
\ddot{n}\end{array}$ & 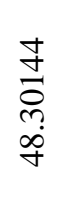 & $\begin{array}{l} \pm \\
\delta \\
\delta \\
\vdots \\
\infty\end{array}$ & $\begin{array}{l}8 \\
0 \\
\dot{0} \\
\stackrel{0}{0}\end{array}$ & $\begin{array}{l}n \\
\hat{\sigma} \\
i n \\
0 \\
0\end{array}$ & $\begin{array}{l}8 \\
\text { ते }\end{array}$ \\
\hline 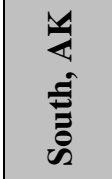 & ్ㅗ & $\infty$ & $\begin{array}{l}\vec{J} \\
\dot{\Xi} \\
\text { ते }\end{array}$ & $\begin{array}{l}\frac{n}{5} \\
\frac{+}{5} \\
\vdots \\
0\end{array}$ & $\begin{array}{l}\text { ô } \\
\text { } \\
\infty \\
+ \\
+\end{array}$ & 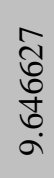 & $\begin{array}{l}\infty \\
0 \\
\stackrel{0}{2}\end{array}$ & $\begin{array}{l}\stackrel{m}{\hat{\sigma}} \\
\dot{+}\end{array}$ & $\begin{array}{l}n \\
\stackrel{n}{n} \\
n\end{array}$ \\
\hline 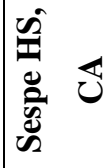 & ్ㅗ & 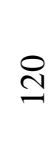 & 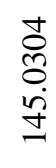 & $\begin{array}{l}0 \\
\dot{0} \\
0 \\
+ \\
\dot{0}\end{array}$ & 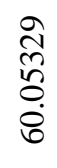 & 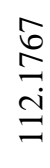 & $\begin{array}{l}\hat{\sigma} \\
\overrightarrow{\tilde{N}}\end{array}$ & \begin{tabular}{l}
$\bar{\infty}$ \\
$\infty$ \\
\multirow{N}{n}{} \\
in
\end{tabular} & $\begin{array}{l}\overrightarrow{+} \\
\stackrel{0}{0} \\
\stackrel{+}{0}\end{array}$ \\
\hline 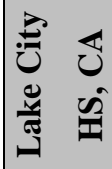 & त् & 0 & $\begin{array}{l}\overline{\tilde{N}} \\
\ddot{n} \\
\dot{\Xi}\end{array}$ & $\begin{array}{l}n \\
m \\
\infty \\
\infty\end{array}$ & 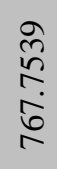 & 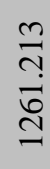 & $\begin{array}{l}\text { वे } \\
\stackrel{\infty}{+} \\
\text { d }\end{array}$ & $\begin{array}{l}\frac{\sigma}{\sigma} \\
\frac{\sigma}{\sigma} \\
\frac{\sigma}{\sigma}\end{array}$ & 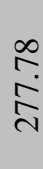 \\
\hline
\end{tabular}




\begin{tabular}{|c|c|c|c|c|c|c|c|c|c|c|}
\hline$\frac{\tilde{n}}{\tilde{z}}$ & 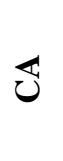 & กิ & 8 & 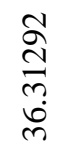 & $\begin{array}{l}\vec{J} \\
\stackrel{0}{0} \\
\stackrel{-}{-}\end{array}$ & $\begin{array}{l}+ \\
\infty \\
\stackrel{\infty}{0} \\
\stackrel{0}{0}\end{array}$ & 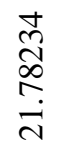 & $\vec{\sim}$ & $\begin{array}{l}\text { ڤ్ } \\
\text { } \\
\stackrel{9}{=}\end{array}$ & $\begin{array}{l}8 \\
\stackrel{0}{0}\end{array}$ \\
\hline E & 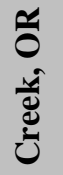 & $\frac{0}{a}$ & $\stackrel{n}{=}$ & $\begin{array}{l}\stackrel{\infty}{N} \\
\underset{\sim}{\tilde{D}} \\
\stackrel{D}{ }\end{array}$ & $\begin{array}{l}\frac{n}{\hat{\Delta}} \\
0 \\
\stackrel{0}{0}\end{array}$ & $\begin{array}{l}\frac{m}{\sigma} \\
\stackrel{\sigma}{f} \\
\dot{q}\end{array}$ & 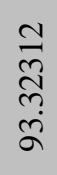 & $\begin{array}{l}\sigma \\
\stackrel{\sigma}{0} \\
\stackrel{\infty}{\pi}\end{array}$ & 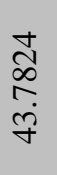 & $\begin{array}{l}\stackrel{a}{+} \\
\stackrel{+}{+} \\
\text { d }\end{array}$ \\
\hline$\frac{\vec{b}}{\stackrel{3}{Z}}$ & $\begin{array}{l}\text { Oै } \\
\hat{\Omega}\end{array}$ & స్ & $\ddot{n}$ & 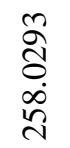 & 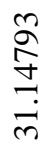 & $\begin{array}{l}\cong \\
\\
\stackrel{n}{=}\end{array}$ & 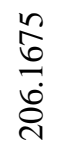 & $\begin{array}{l}\tilde{c} \\
\dot{d} \\
\tilde{\lambda}\end{array}$ & 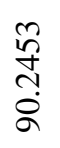 & $\begin{array}{l}\hat{b} \\
\hat{\delta} \\
\text { }\end{array}$ \\
\hline 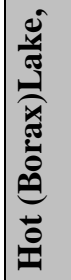 & 号 & กิ & ำ & $\begin{array}{l}\text { న̂ } \\
\text { m. } \\
\infty \\
i n \\
i n\end{array}$ & $\begin{array}{l}0 \\
\infty \\
\infty \\
\infty \\
\infty \\
\infty \\
\infty\end{array}$ & $\begin{array}{l}\infty \\
\infty \\
6 \\
\infty \\
\infty \\
\infty\end{array}$ & $\begin{array}{l}n \\
\infty \\
\infty \\
\infty \\
\dot{D} \\
\stackrel{n}{n}\end{array}$ & $\begin{array}{l}0 \\
\stackrel{a}{d} \\
\stackrel{d}{d}\end{array}$ & 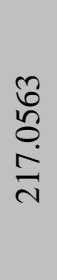 & $\begin{array}{r}\hat{\kappa} \\
\hat{N}\end{array}$ \\
\hline 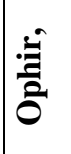 & 4 & ్ㅗ & $\infty$ & $\begin{array}{l}\hat{\widehat{N}} \\
\stackrel{\infty}{0}\end{array}$ & 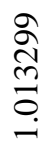 & 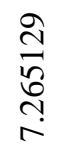 & $\begin{array}{l}\infty \\
\stackrel{0}{d} \\
0 \\
\stackrel{2}{2}\end{array}$ & $\begin{array}{l}8 \\
\dot{0} \\
\infty\end{array}$ & $\frac{\substack{n\\
}}{n}$ & $\frac{m}{\dot{d}}$ \\
\hline 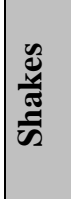 & 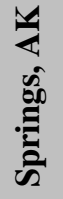 & त् & ฉ & $\begin{array}{l}\stackrel{0}{n} \\
\stackrel{n}{+} \\
\text { ¿ }\end{array}$ & $\begin{array}{l}\stackrel{2}{\infty} \\
\stackrel{+}{+} \\
\stackrel{0}{0} \\
0\end{array}$ & 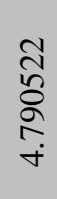 & \begin{tabular}{l}
0 \\
\multirow{2}{0}{} \\
0 \\
0
\end{tabular} & $\underset{i}{\stackrel{J}{i}}$ & $\begin{array}{l}\frac{n}{\mathfrak{a}} \\
\stackrel{+}{+}\end{array}$ & $\stackrel{n}{i n}$ \\
\hline 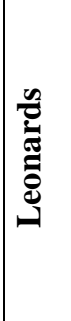 & 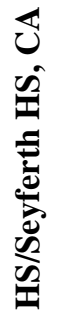 & ్ㅗ & 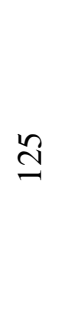 & $\begin{array}{l}\infty \\
2 \\
\tilde{n} \\
\stackrel{m}{n}\end{array}$ & $\begin{array}{l}\hat{a} \\
\stackrel{3}{=} \\
=\end{array}$ & 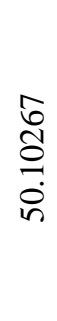 & 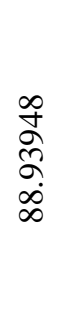 & $\begin{array}{l}n \\
n \\
\infty \\
=\end{array}$ & $\begin{array}{l}\infty \\
\stackrel{\infty}{n} \\
\infty \\
\infty \\
\infty\end{array}$ & $\begin{array}{l}\bar{\infty} \\
\stackrel{\infty}{\varrho}\end{array}$ \\
\hline 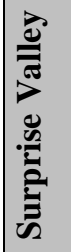 & $\begin{array}{l}\tilde{U} \\
\hat{\Xi}\end{array}$ & ్ㅗ & $\stackrel{n}{\beth}$ & $\begin{array}{l}n \\
\infty \\
m \\
\tilde{o} \\
0\end{array}$ & 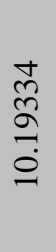 & $\begin{array}{l}\underset{+}{+} \\
\text { } \\
\stackrel{0}{0} \\
+\end{array}$ & $\begin{array}{l}\hat{\sigma} \\
\infty \\
\infty \\
\infty \\
\dot{r}\end{array}$ & $\begin{array}{l}\stackrel{2}{\circ} \\
\infty \\
\stackrel{0}{+}\end{array}$ & 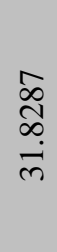 & 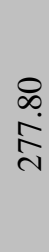 \\
\hline
\end{tabular}




\begin{tabular}{|c|c|c|c|c|c|c|c|c|c|}
\hline 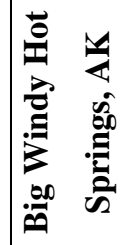 & ్ㅗ & $\curvearrowleft$ & $\begin{array}{l}0 \\
\infty \\
0 \\
0 \\
\infty \\
\infty\end{array}$ & 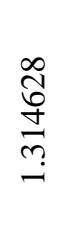 & $\begin{array}{l}\bar{\infty} \\
\tilde{n} \\
\tilde{n} \\
\tilde{n}\end{array}$ & $\begin{array}{l}\frac{a}{\infty} \\
= \\
i n \\
i n\end{array}$ & $\begin{array}{l}\text { ले } \\
\text { ஸे }\end{array}$ & के & $\begin{array}{l}\hat{\sigma} \\
\dot{y}\end{array}$ \\
\hline 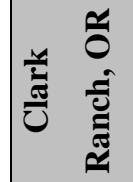 & $\begin{array}{l}\text { N } \\
\text { I }\end{array}$ & $\stackrel{\varrho}{ }$ & $\begin{array}{l}\tilde{\delta} \\
\tilde{\infty} \\
\dot{8} \\
\delta\end{array}$ & 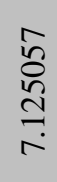 & $\begin{array}{l}\mathscr{2} \\
\stackrel{\Xi}{=} \\
\dot{m}\end{array}$ & 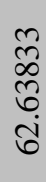 & $\begin{array}{l}\text { oे } \\
\text { dे }\end{array}$ & $\begin{array}{l}\text { +े } \\
\text { సे } \\
\text { ते }\end{array}$ & \begin{tabular}{l}
8 \\
$\infty$ \\
$\infty$ \\
\multirow{2}{*}{}
\end{tabular} \\
\hline 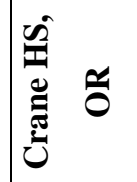 & ָี & $\stackrel{2}{\varrho}$ & 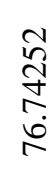 & 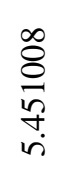 & 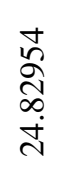 & 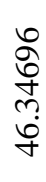 & $\frac{\mathfrak{I}}{\stackrel{a}{d}}$ & 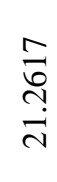 & 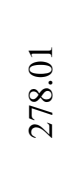 \\
\hline 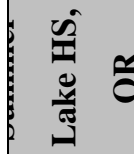 & $\stackrel{ }{0}$ & $\stackrel{\varrho}{ }$ & $\begin{array}{l}\stackrel{\nabla}{Z} \\
\dot{J} \\
\dot{J}\end{array}$ & 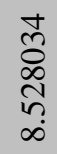 & $\begin{array}{l}\infty \\
\infty \\
n \\
n \\
o \\
+\end{array}$ & 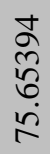 & $\begin{array}{l}\hat{\sigma} \\
\dot{m} \\
m\end{array}$ & $\begin{array}{l}n \\
n \\
n \\
n\end{array}$ & $\begin{array}{l}\text { ñ } \\
\text { in } \\
\text { in }\end{array}$ \\
\hline 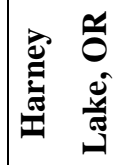 & $\begin{array}{l}\text { N } \\
\text { I }\end{array}$ & ? & $\begin{array}{l}\stackrel{\alpha}{+} \\
\underset{\infty}{\infty} \\
\dot{D}\end{array}$ & 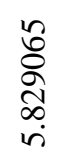 & $\begin{array}{l}\infty \\
\infty \\
+ \\
\vdots \\
\\
\end{array}$ & 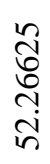 & 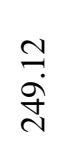 & 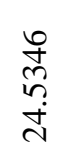 & 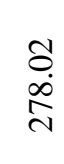 \\
\hline 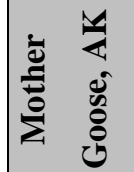 & ్ㅗ & 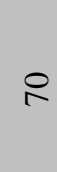 & 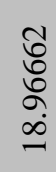 & $\begin{array}{l}\infty \\
\infty \\
\infty \\
\infty \\
\infty \\
0\end{array}$ & 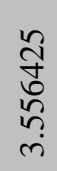 & $\begin{array}{l}\frac{\infty}{6} \\
\frac{8}{8} \\
0 \\
0\end{array}$ & 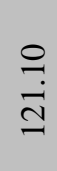 & $\begin{array}{l}\stackrel{8}{8} \\
\dot{+} \\
\dot{q}\end{array}$ & $\begin{array}{l}\text { m. } \\
m \\
m\end{array}$ \\
\hline 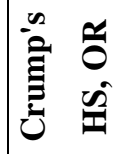 & ్ㅗ & $\stackrel{\cap}{n}$ & $\begin{array}{l}\frac{0}{\pi} \\
\frac{\sigma}{\sigma} \\
\frac{\sigma}{6}\end{array}$ & $\frac{2}{8}$ & 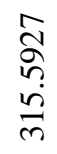 & 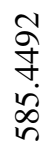 & 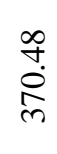 & $\begin{array}{l}0 \\
\infty \\
\infty \\
0 \\
\stackrel{n}{\hat{N}}\end{array}$ & $\begin{array}{l}\stackrel{1}{a} \\
\text { J }\end{array}$ \\
\hline 泀 & กิ & ?c & 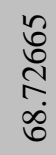 & $\begin{array}{l}\underset{N}{\infty} \\
\infty \\
\infty \\
\infty \\
+\end{array}$ & 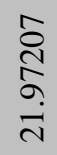 & $\frac{\text { ন }}{\hat{\sigma}}$ & 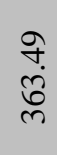 & $\underset{\cong}{\stackrel{N}{\Xi}}$ & $\begin{array}{l}\hat{b} \\
\dot{8} \\
\&\end{array}$ \\
\hline 兽 & ڤ્స & 8 & $\begin{array}{l}\vec{\infty} \\
i n \\
0 \\
\dot{n} \\
i\end{array}$ & $\begin{array}{l}\hat{n} \\
\hat{\sigma} \\
\dot{\sigma}\end{array}$ & \begin{tabular}{l}
2 \\
2 \\
\multirow{2}{0}{} \\
$\dot{0}$
\end{tabular} & 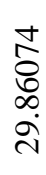 & $\begin{array}{l}\stackrel{P}{0} \\
\infty \\
\text { N }\end{array}$ & $\stackrel{m}{\stackrel{n}{n}}$ & 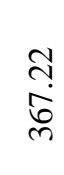 \\
\hline 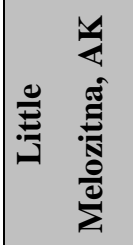 & ్ㅗ & $\infty$ & $\begin{array}{l}+ \\
\infty \\
0 \\
0 \\
i \\
\text { in }\end{array}$ & $\frac{\stackrel{g}{+}}{\frac{\pi}{d}}$ & 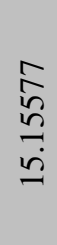 & 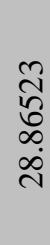 & $\begin{array}{l}\text { ț } \\
\text { ஸூ } \\
\text { లె }\end{array}$ & $\begin{array}{l}0 \\
0 \\
0 \\
\dot{2}\end{array}$ & 홍 \\
\hline
\end{tabular}




\begin{tabular}{|c|c|c|c|c|c|c|c|c|c|}
\hline 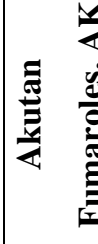 & ิㅗㄱ & 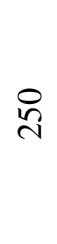 & $\frac{\bar{a}}{\vec{a}}$ & 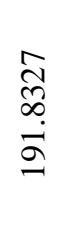 & $\begin{array}{l}\stackrel{2}{2} \\
\dot{n} \\
\ddot{b}\end{array}$ & $\begin{array}{l}\stackrel{n}{n} \\
\stackrel{2}{\Xi} \\
=\end{array}$ & $\begin{array}{l}\stackrel{\infty}{n} \\
\dot{\sim} \\
m \\
m\end{array}$ & $\begin{array}{l}\stackrel{0}{N} \\
\text { ñ } \\
\stackrel{0}{0} \\
\stackrel{n}{n}\end{array}$ & 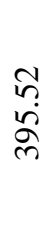 \\
\hline 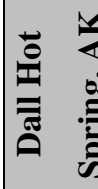 & 고 & $\curvearrowleft$ & 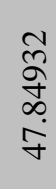 & $\begin{array}{l}\underset{\sigma}{\sigma} \\
\stackrel{\infty}{\infty} \\
\infty \\
i\end{array}$ & 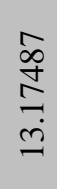 & $\begin{array}{l}\stackrel{0}{+} \\
\stackrel{\alpha}{+} \\
\dot{d}\end{array}$ & 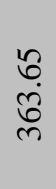 & 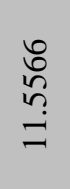 & 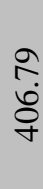 \\
\hline 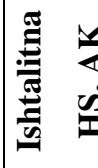 & त् & $\stackrel{\imath}{\varrho}$ & 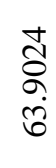 & $\begin{array}{l}\mathcal{N} \\
\infty \\
\infty \\
\infty \\
\infty \\
\infty \\
\dot{\infty}\end{array}$ & $\begin{array}{l}\widehat{N} \\
\hat{\sigma} \\
\stackrel{0}{0}\end{array}$ & 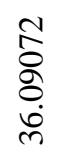 & $\begin{array}{l}\hat{n} \\
\hat{n} \\
\text { ñ }\end{array}$ & $\begin{array}{l}\text { 年 } \\
\text { in } \\
\text { I }\end{array}$ & $\begin{array}{l}\stackrel{2}{0} \\
\stackrel{0}{\circ}\end{array}$ \\
\hline 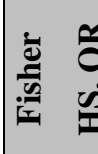 & त् & $\curvearrowleft$ & 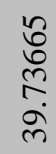 & $\begin{array}{c}\hat{a} \\
\hat{d} \\
\infty \\
i\end{array}$ & $\begin{array}{l}\stackrel{8}{\circ} \\
\stackrel{n}{5} \\
=\end{array}$ & 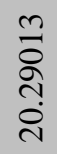 & $\begin{array}{l}\mathfrak{n} \\
\stackrel{2}{0} \\
m\end{array}$ & 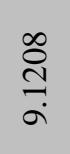 & 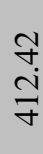 \\
\hline 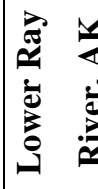 & त् & $\infty$ & 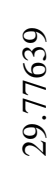 & 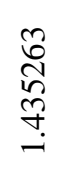 & 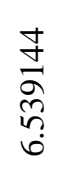 & 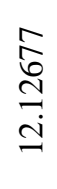 & $\begin{array}{l}m \\
\underset{n}{0}\end{array}$ & $\begin{array}{l}\stackrel{2}{\curvearrowright} \\
\text { in }\end{array}$ & $\frac{f}{\stackrel{f}{8}}$ \\
\hline$\underset{\pi}{\approx}$ & त् & $\infty$ & 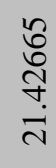 & $\begin{array}{l}2 \\
\hat{\sigma} \\
\hat{\sigma} \\
\vdots \\
\vdots\end{array}$ & $\begin{array}{l}\overline{8} \\
8 \\
0 \\
0 \\
\dot{+}\end{array}$ & 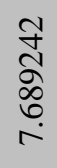 & $\begin{array}{l}8 \\
\stackrel{0}{+} \\
\dot{0}\end{array}$ & $\begin{array}{l}\stackrel{\vartheta}{0} \\
\dot{+} \\
\dot{r}\end{array}$ & $\stackrel{\text { ते }}{\stackrel{+}{+}}$ \\
\hline 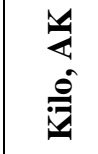 & त् & $\stackrel{n}{r}$ & $\begin{array}{l}\bar{a} \\
\infty \\
\dot{\infty} \\
\ddot{\lambda}\end{array}$ & \begin{tabular}{l}
$\bar{\infty}$ \\
\multirow{0}{0}{} \\
0 \\
+ \\
0
\end{tabular} & $\begin{array}{l}\vec{n} \\
\tilde{n} \\
\tilde{\sigma} \\
\tilde{r}\end{array}$ & $\begin{array}{l}\frac{n}{\alpha} \\
\frac{\tilde{\sigma}}{2} \\
0 \\
\dot{n}\end{array}$ & \begin{tabular}{l}
$\stackrel{\overbrace{}}{+}$ \\
\multirow{d}{0}{}
\end{tabular} & $\frac{\tilde{n}}{\stackrel{i}{i}}$ & $\frac{\stackrel{9}{+}}{\stackrel{5}{+}}$ \\
\hline 记 & 곡 & $\stackrel{n}{r}$ & 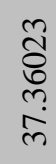 & 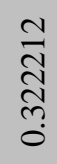 & 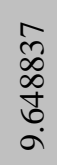 & $\begin{array}{l}\bar{\infty} \\
\infty \\
\tilde{n} \\
\\
\stackrel{\sim}{\sim}\end{array}$ & $\begin{array}{l}\stackrel{\infty}{1} \\
\stackrel{0}{0}\end{array}$ & $\begin{array}{l}\hat{n} \\
\text { ஸे } \\
\dot{I}\end{array}$ & $\begin{array}{l}\text { बे } \\
\text { }\end{array}$ \\
\hline 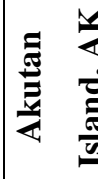 & ్ㅗ & 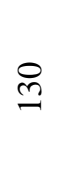 & 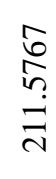 & 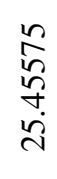 & 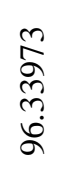 & 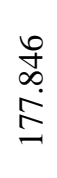 & $\begin{array}{l}\mathfrak{q} \\
\dot{q} \\
m\end{array}$ & 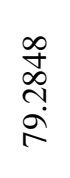 & $\begin{array}{l}\stackrel{2}{\hat{n}} \\
\stackrel{\mathrm{m}}{\mathrm{m}}\end{array}$ \\
\hline 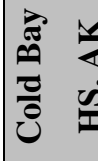 & तี & ฉ & 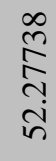 & \begin{tabular}{l}
$\tilde{F}$ \\
\multirow{H}{*}{} \\
$\infty$ \\
$\infty$ \\
$\dot{n}$
\end{tabular} & $\begin{array}{l}8 \\
\stackrel{0}{\Xi} \\
= \\
\end{array}$ & $\frac{\sqrt[n]{n}}{\stackrel{n}{n}}$ & $\begin{array}{l}\text { f } \\
\tilde{n} \\
\tilde{n}\end{array}$ & $\begin{array}{l}\stackrel{m}{\pi} \\
\infty \\
\dot{n} \\
\stackrel{n}{n}\end{array}$ & $\begin{array}{l}\text { ठ } \\
\text { ळे } \\
\text { ले }\end{array}$ \\
\hline
\end{tabular}




\begin{tabular}{|c|c|c|c|c|c|c|c|c|c|}
\hline 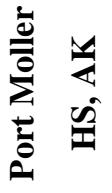 & ్ㅗㄱ & $\triangleright$ & $\frac{7}{\frac{7}{n}}$ & 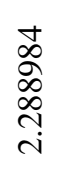 & 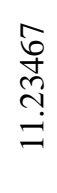 & $\begin{array}{l}\overline{8} \\
\tilde{n} \\
\hat{n}\end{array}$ & $\begin{array}{l}m \\
\dot{0} \\
\stackrel{n}{n}\end{array}$ & $\begin{array}{l}\text { aे } \\
\text { ర్ } \\
\text { = }\end{array}$ & $\begin{array}{l}\text { It } \\
\stackrel{\circ}{\circ}\end{array}$ \\
\hline 春 & ్ㅗㄱ & $\infty$ & $\underset{\infty}{+}$ & 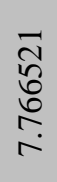 & $\begin{array}{l}\stackrel{0}{\pi} \\
\stackrel{2}{2} \\
6 \\
0\end{array}$ & 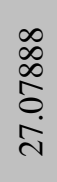 & $\begin{array}{l}\bar{\sigma} \\
\dot{0} \\
n \\
m\end{array}$ & $\begin{array}{l}2 \\
\stackrel{0}{0} \\
0\end{array}$ & $\begin{array}{l}\overrightarrow{1} \\
\text { ळे }\end{array}$ \\
\hline 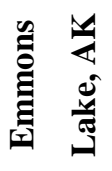 & $\begin{array}{l}\text { ก } \\
\text { nิ }\end{array}$ & $\curvearrowleft$ & \begin{tabular}{l}
$\hat{\infty}$ \\
$\infty$ \\
\multirow{+}{m}{} \\
$\dot{\infty}$ \\
+
\end{tabular} & 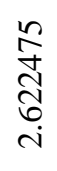 & 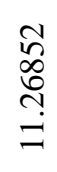 & $\begin{array}{l}\hat{\sigma} \\
\hat{n} \\
\infty \\
\dot{\lambda}\end{array}$ & $\begin{array}{l}n \\
\text { ñ } \\
\stackrel{n}{n} \\
m\end{array}$ & $\begin{array}{l}\text { 조 } \\
\text { N̦ } \\
\stackrel{0}{0}\end{array}$ & 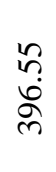 \\
\hline 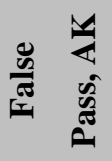 & ్ㅠㅁ & $\infty$ & 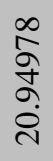 & 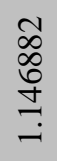 & $\begin{array}{l}\frac{a}{a} \\
\frac{\hat{n}}{2} \\
\overrightarrow{+}\end{array}$ & $\begin{array}{l}n \\
\frac{n}{6} \\
\infty \\
\infty\end{array}$ & $\begin{array}{l}\circ \\
\text { ఠं } \\
n \\
m\end{array}$ & $\begin{array}{l}\hat{\sigma} \\
\text { ñ. } \\
\text { m. }\end{array}$ & $\begin{array}{l}\text { ̊ू } \\
\text { ळू } \\
\text { ले }\end{array}$ \\
\hline 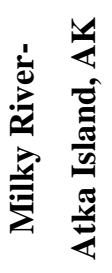 & $\begin{array}{l}\text { ก } \\
\text { กิ- }\end{array}$ & $\stackrel{\mathscr{n}}{\mathrm{N}}$ & 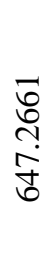 & 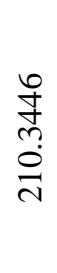 & 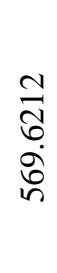 & 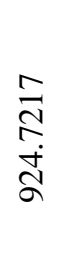 & $\begin{array}{l}\circ \\
\text { oे } \\
\text { ᄋ̊ }\end{array}$ & $\begin{array}{l}\vec{\infty} \\
\infty \\
i \\
i n \\
n\end{array}$ & $\begin{array}{l}\stackrel{2}{0} \\
\hat{\infty} \\
0\end{array}$ \\
\hline 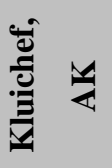 & त్ & సે & $\frac{\bar{n}}{\stackrel{\infty}{\bar{n}}}$ & $\begin{array}{l}\hat{0} \\
n \\
n \\
\hat{n} \\
\text { ñ }\end{array}$ & $\begin{array}{l}\bar{F} \\
\text { ले } \\
\infty \\
\text { ले }\end{array}$ & $\begin{array}{l}\text { సे } \\
\text { ல் } \\
\text { in }\end{array}$ & $\begin{array}{l} \pm \\
\vec{d} \\
\stackrel{0}{\circ}\end{array}$ & $\begin{array}{l}0 \\
6 \\
0 \\
i n \\
n\end{array}$ & $\begin{array}{l}\stackrel{8}{0} \\
\hat{+} \\
\stackrel{0}{0}\end{array}$ \\
\hline 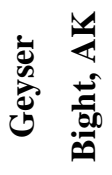 & त् & 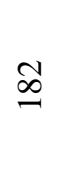 & $\begin{array}{l}\text { fo } \\
\text { D } \\
\text { I }\end{array}$ & $\begin{array}{l}n \\
\infty \\
\infty \\
\infty \\
m\end{array}$ & $\begin{array}{l}\text { ते } \\
\text { ñ } \\
\text { ूू }\end{array}$ & $\begin{array}{l}\vec{g} \\
\stackrel{j}{\Xi}\end{array}$ & $\begin{array}{l}0 \\
\frac{0}{0} \\
a\end{array}$ & $\begin{array}{l}n \\
\hat{n} \\
\infty \\
n \\
n\end{array}$ & $\begin{array}{l}\stackrel{8}{0} \\
\stackrel{\infty}{0} \\
\stackrel{0}{0}\end{array}$ \\
\hline 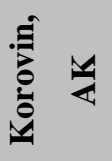 & ్ㅗ & $\stackrel{P}{ }$ & 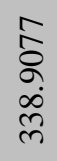 & 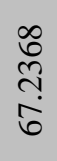 & 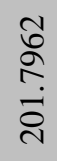 & 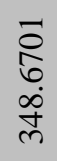 & $\begin{array}{l}\text { ஜn } \\
\text { oे } \\
\text { ò }\end{array}$ & \begin{tabular}{l}
0 \\
\multirow{1}{0}{} \\
$\dot{y}$ \\
\pm \\
$\vdots$
\end{tabular} & 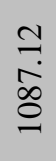 \\
\hline $\begin{array}{l}\frac{y}{4} \\
\frac{1}{5} \\
\frac{0}{4}\end{array}$ & กิ & $\stackrel{n}{n}$ & 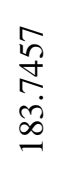 & 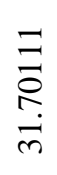 & $\begin{array}{l}\vec{n} \\
\stackrel{n}{a} \\
\stackrel{a}{n}\end{array}$ & $\begin{array}{l}n \\
0 \\
0 \\
0\end{array}$ & $\begin{array}{l}\hat{n} \\
\hat{\alpha}\end{array}$ & $\begin{array}{l}\hat{\infty} \\
\stackrel{8}{0} \\
i\end{array}$ & $\begin{array}{l}n \\
\stackrel{1}{0} \\
0 \\
0\end{array}$ \\
\hline 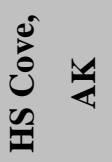 & ్ㅡㅁ & $\stackrel{\varrho}{=}$ & 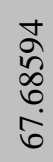 & $\begin{array}{l}\hat{\widehat{o}} \\
\stackrel{n}{n} \\
\text { n? }\end{array}$ & $\begin{array}{l}2 \\
0 \\
0 \\
\text { ते }\end{array}$ & $\begin{array}{l}\infty \\
\infty \\
\hat{n} \\
\infty \\
\dot{m}\end{array}$ & $\begin{array}{l}\text { के } \\
\hat{\alpha} \\
\hat{\alpha}\end{array}$ & $\begin{array}{l}\text { ô } \\
\stackrel{+}{1} \\
\stackrel{-}{-}\end{array}$ & $\begin{array}{l}0 \\
\text { n̊? } \\
\infty \\
0\end{array}$ \\
\hline
\end{tabular}




\begin{tabular}{|c|c|c|c|c|c|c|c|c|c|c|}
\hline 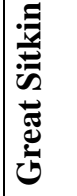 & 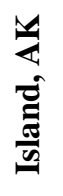 & กี & 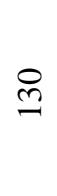 & $\underset{\substack{n \\
i}}{\stackrel{\infty}{a}}$ & $\underset{\substack{n \\
\stackrel{\sim}{f}}}{\stackrel{n}{\sim}}$ & $\begin{array}{l}\infty \\
\stackrel{0}{n} \\
\stackrel{n}{+} \\
\stackrel{+}{\infty} \\
\infty\end{array}$ & $\begin{array}{l}n \\
\\
0 \\
0\end{array}$ & 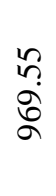 & $\begin{array}{l}\infty \\
\frac{\infty}{\delta} \\
\infty \\
\infty\end{array}$ & $\begin{array}{l}\stackrel{\overbrace{}}{\hat{0}} \\
\infty \\
0\end{array}$ \\
\hline 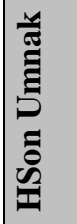 & 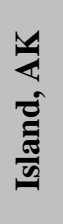 & ్ㅗ & 8 & $\begin{array}{l}\stackrel{\wp}{8} \\
\stackrel{J}{\sigma} \\
\stackrel{\sigma}{q}\end{array}$ & $\begin{array}{l}\stackrel{\infty}{\sigma} \\
\underset{J}{J} \\
\stackrel{+}{+}\end{array}$ & 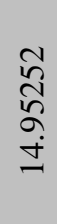 & 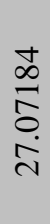 & $\begin{array}{l}\frac{0}{0} \\
\frac{\rho}{a}\end{array}$ & $\begin{array}{l}\infty \\
\stackrel{\infty}{f} \\
\stackrel{+}{J}\end{array}$ & $\begin{array}{l}\stackrel{+}{n} \\
\infty \\
0 \\
0\end{array}$ \\
\hline 咅 & 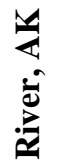 & ్ㅗ & $\infty$ & $\begin{array}{l}\mathscr{1} \\
\infty \\
\infty \\
\infty \\
\infty \\
\stackrel{1}{0}\end{array}$ & 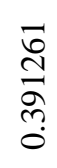 & 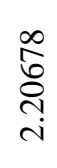 & $\begin{array}{l}n \\
\hat{\alpha} \\
\hat{\alpha} \\
\text { no }\end{array}$ & $\frac{\text { ñ }}{\hat{\sigma}}$ & ્ָసે & $\begin{array}{l}\stackrel{2}{0} \\
\infty \\
\infty \\
0\end{array}$ \\
\hline 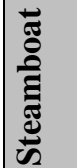 & 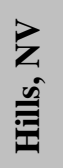 & तี & $\stackrel{0}{\sim}$ & $\begin{array}{l}\frac{m}{n} \\
\tilde{n} \\
\tilde{n}\end{array}$ & 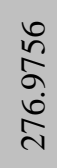 & 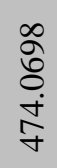 & $\begin{array}{l}\text { Jे } \\
\infty \\
0 \\
\dot{1} \\
0 \\
0\end{array}$ & $\stackrel{n}{n}$ & 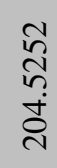 & $\begin{array}{c}\text { ָे. } \\
\text { ते }\end{array}$ \\
\hline 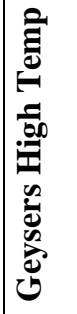 & 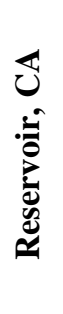 & $\underset{\infty}{\infty}$ & $\frac{n}{n}$ & $\frac{n}{\infty}$ & 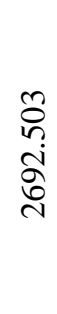 & 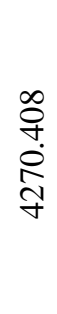 & $\begin{array}{l}\mathcal{N} \\
\text { ஸे } \\
\infty \\
\infty \\
\infty \\
\infty\end{array}$ & $\begin{array}{l}\text { ָे } \\
\text { nn }\end{array}$ & $\begin{array}{l}\hat{\alpha} \\
\hat{\sigma} \\
\bar{\sigma}\end{array}$ & 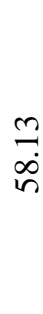 \\
\hline 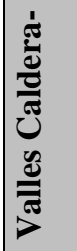 & 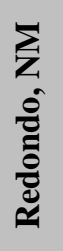 & $\begin{array}{c}n \\
m \\
m\end{array}$ & $\stackrel{n}{\curvearrowright}$ & $\begin{array}{l}\frac{\hat{\sigma}}{\sigma} \\
\text { ळે }\end{array}$ & 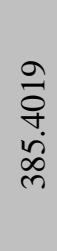 & 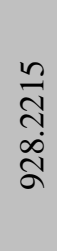 & $\begin{array}{l}\text { N } \\
\stackrel{2}{\rho} \\
\stackrel{f}{ \pm}\end{array}$ & $\begin{array}{l}\stackrel{\vartheta}{+} \\
\stackrel{r}{r}\end{array}$ & $\frac{\hat{a}}{\infty} \underset{\dot{n}}{i}$ & $\stackrel{\swarrow}{\curvearrowright}$ \\
\hline 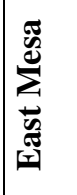 & 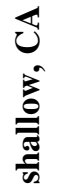 & $\stackrel{?}{0}$ & $\tilde{6}$ & $\begin{array}{l}\infty \\
\delta \\
+ \\
\stackrel{\sigma}{\sigma} \\
\stackrel{\sim}{v}\end{array}$ & $\begin{array}{l}\text { సे } \\
\text { సે } \\
\stackrel{\text { సे }}{\text { ते }}\end{array}$ & $\begin{array}{l}\stackrel{N}{+} \\
\stackrel{+}{+} \\
\stackrel{+}{=}\end{array}$ & $\begin{array}{l}\hat{n} \\
\stackrel{n}{0} \\
\hat{\sigma}\end{array}$ & $\begin{array}{l}\text { rn } \\
\infty \\
\infty \\
\infty\end{array}$ & $\begin{array}{l}\frac{m}{5} \\
\stackrel{m}{n} \\
\stackrel{2}{\infty}\end{array}$ & \\
\hline 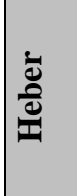 & $\begin{array}{l}\text { U } \\
\text { है } \\
\frac{\hat{\sigma}}{\bar{E}}\end{array}$ & స్ & $\stackrel{?}{I}$ & $\begin{array}{l}\hat{\delta} \\
0 \\
0 \\
0 \\
0\end{array}$ & 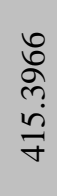 & 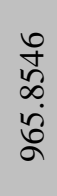 & $\begin{array}{l}\overline{0} \\
\text { ஸे } \\
\text { ñ }\end{array}$ & $\frac{\sigma}{\tilde{N}}$ & $\begin{array}{l}\bar{n} \\
\text { n. } \\
\text { ñ } \\
i n\end{array}$ & $\begin{array}{l}\bar{b} \\
\dot{0} \\
\text { mे }\end{array}$ \\
\hline
\end{tabular}




\begin{tabular}{|c|c|c|c|c|c|c|c|c|c|c|}
\hline 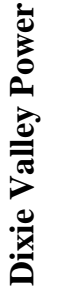 & 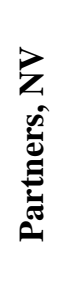 & तิ & $\underset{\sim}{\infty}$ & 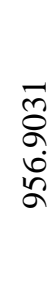 & $\begin{array}{l}\underset{f}{+} \\
\infty \\
\dot{f} \\
\dot{f}\end{array}$ & 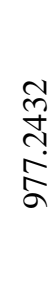 & $\begin{array}{l}\vec{\sim} \\
\stackrel{n}{g} \\
\Xi\end{array}$ & $\begin{array}{l}\infty \\
\dot{+} \\
\dot{\infty}\end{array}$ & 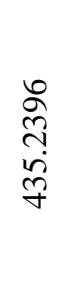 & $\frac{\infty}{\mathscr{n}}$ \\
\hline 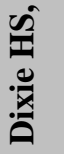 & z & ஓి & 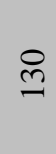 & 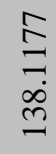 & $\begin{array}{l}\stackrel{8}{2} \\
\stackrel{2}{2} \\
\stackrel{0}{0}\end{array}$ & $\begin{array}{l}n \\
\infty \\
\infty \\
0 \\
\infty \\
i\end{array}$ & 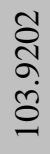 & $\begin{array}{l}\infty \\
\infty \\
\infty \\
\infty\end{array}$ & 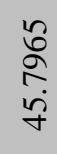 & $\frac{\infty}{n}$ \\
\hline 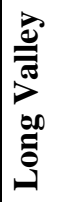 & 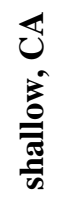 & ஜి & $\stackrel{n}{I}$ & $\begin{array}{l}\text { فे } \\
\dot{\delta} \\
\dot{\delta}\end{array}$ & $\begin{array}{l}+ \\
\stackrel{\infty}{0} \\
\sigma \\
i \\
i n\end{array}$ & $\begin{array}{l}\hat{N} \\
\stackrel{n}{n} \\
\stackrel{n}{c}\end{array}$ & 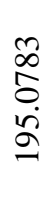 & $\begin{array}{l}\stackrel{\infty}{n} \\
\text { ñ }\end{array}$ & $\begin{array}{l}\stackrel{\nabla}{\sim} \\
\stackrel{\Omega}{R}\end{array}$ & $\begin{array}{l}0 \\
\infty \\
\infty\end{array}$ \\
\hline 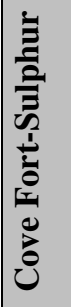 & 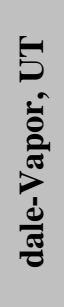 & 8 & $n$ & $\begin{array}{l}\vec{J} \\
\infty \\
\mathbb{N} \\
\text { d }\end{array}$ & 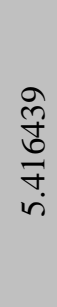 & $\begin{array}{l}\overline{8} \\
\mathbb{D} \\
\\
\text { I }\end{array}$ & 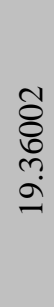 & $\frac{\pi}{\pi}$ & $\underset{\Omega}{\stackrel{g}{r}}$ & 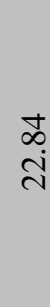 \\
\hline
\end{tabular}


Table A-2: Undiscovered Hydrothermal Resources

\begin{tabular}{|c|c|c|c|c|c|c|c|c|c|c|}
\hline 里 & 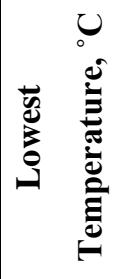 & 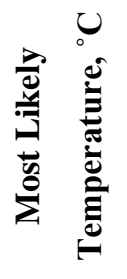 & & 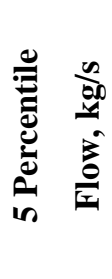 & 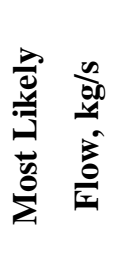 & 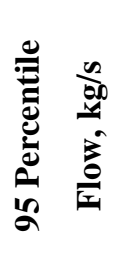 & 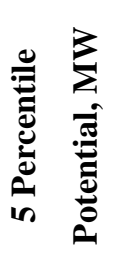 & 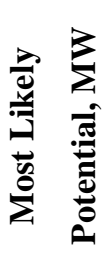 & 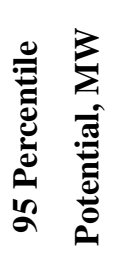 & 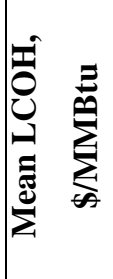 \\
\hline $\begin{array}{l}0 \\
0 \\
8 \\
\bar{v} \\
2 \\
4\end{array}$ & \begin{tabular}{l}
0 \\
\multirow{2}{n}{} \\
กิ \\
0
\end{tabular} & $\begin{array}{l}\stackrel{8}{\circ} \\
\stackrel{n}{\circ} \\
0 \\
=\end{array}$ & 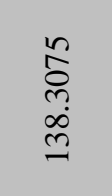 & 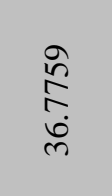 & 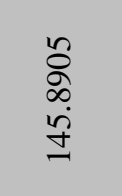 & $\begin{array}{l}\frac{n}{o} \\
\text { ลे } \\
\text { nे }\end{array}$ & 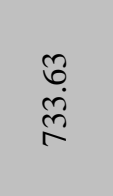 & 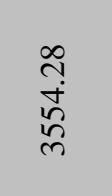 & $\begin{array}{l}\text { ले } \\
\text { ర્ठ } \\
\text { ర్ర }\end{array}$ & $\begin{array}{l}\stackrel{P}{ \pm} \\
\dot{\Xi}\end{array}$ \\
\hline $\begin{array}{l}0 \\
0 \\
0 \\
\pi \\
2 \\
4\end{array}$ & 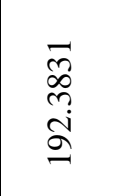 & $\begin{array}{l}\stackrel{0}{n} \\
\stackrel{n}{\vdots} \\
\Xi\end{array}$ & 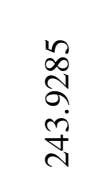 & 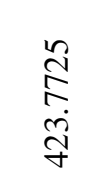 & $\begin{array}{l}\frac{\sigma}{a} \\
\dot{\sigma} \\
\infty \\
\sigma\end{array}$ & \begin{tabular}{l}
$\stackrel{0}{ }$ \\
\multirow{+}{+}{} \\
$\stackrel{0}{0}$ \\
0
\end{tabular} & $\begin{array}{l}n \\
\hat{\sigma} \\
\stackrel{\infty}{+} \\
\dot{f}\end{array}$ & $\begin{array}{l}\stackrel{ }{\Xi} \\
\stackrel{\Xi}{\Xi}\end{array}$ & 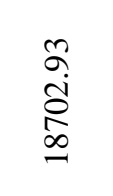 & 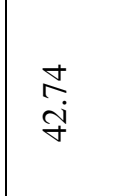 \\
\hline $\begin{array}{l}0 \\
0 \\
0 \\
\bar{n} \\
\underline{1}\end{array}$ & 0 & 0 & 0 & 0 & 0 & 0 & 0 & 0 & 0 & z \\
\hline $\begin{array}{l}0 \\
0 \\
0 \\
\Lambda \\
\hat{\theta}\end{array}$ & 离 & in & : & 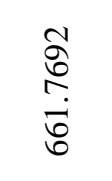 & 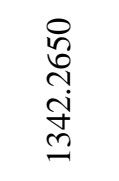 & 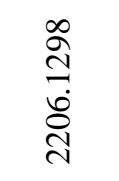 & $\begin{array}{l}\stackrel{a}{g} \\
\stackrel{m}{\Xi}\end{array}$ & 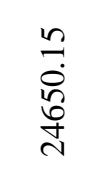 & $\begin{array}{l}n \\
\stackrel{n}{\dot{T}} \\
\stackrel{7}{\infty} \\
\infty\end{array}$ & $\begin{array}{l}\overline{6} \\
\text { in }\end{array}$ \\
\hline $\begin{array}{l}u \\
0 \\
0 \\
\frac{n}{v} \\
\frac{v}{u}\end{array}$ & $\begin{array}{l}\text { ते } \\
\text { న. } \\
\infty \\
0\end{array}$ & 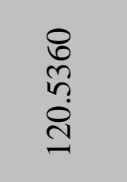 & $\begin{array}{l}\stackrel{8}{2} \\
\stackrel{2}{0} \\
\dot{0}\end{array}$ & $\begin{array}{l}\infty \\
\text { ڤેे } \\
\frac{\dot{\gamma}}{2}\end{array}$ & $\begin{array}{l}\hat{D} \\
\infty \\
i \\
\infty \\
m\end{array}$ & 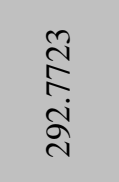 & $\begin{array}{l}\circ \\
\stackrel{\alpha}{\alpha}\end{array}$ & $\begin{array}{l}\hat{\sigma} \\
\text { i } \\
\text { a }\end{array}$ & $\begin{array}{l}\stackrel{m}{n} \\
\stackrel{\infty}{\infty} \\
\stackrel{m}{m}\end{array}$ & $\begin{array}{l}\tilde{n} \\
\text { } \\
\end{array}$ \\
\hline $\begin{array}{l}0 \\
0 \\
0 \\
0 \\
0 \\
0 \\
0\end{array}$ & 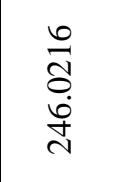 & 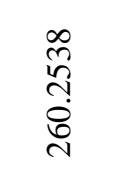 & $\begin{array}{l}\infty \\
\infty \\
\stackrel{n}{0} \\
\stackrel{0}{N}\end{array}$ & 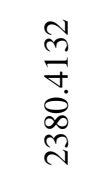 & $\begin{array}{l}5 \\
0 \\
n \\
\infty \\
n \\
2 \\
\infty\end{array}$ & \begin{tabular}{l}
$\hat{i}$ \\
$\stackrel{n}{2}$ \\
$i$ \\
\multirow{2}{*}{} \\
$i$
\end{tabular} & $\begin{array}{l}\vec{m} \\
\text { ळ̊ } \\
\dot{8}\end{array}$ & 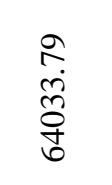 & $\frac{\widetilde{N}}{\stackrel{\Xi}{\Xi}}$ & $\underset{\infty}{\infty}$ \\
\hline $\begin{array}{l}0 \\
0 \\
8 \\
\bar{v} \\
v \\
2\end{array}$ & $\begin{array}{l}\stackrel{a}{0} \\
\tilde{n} \\
\ddot{\infty}\end{array}$ & $\stackrel{ }{=}$ & 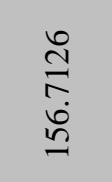 & $\begin{array}{l}\bar{\delta} \\
\text { ○े } \\
\stackrel{0}{0}\end{array}$ & 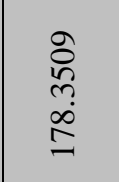 & 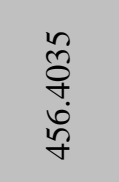 & $\begin{array}{l}\infty \\
\stackrel{\sim}{\sim}\end{array}$ & $\begin{array}{l}\infty \\
0 \\
\dot{0} \\
0\end{array}$ & $\begin{array}{l}\frac{0}{6} \\
\frac{0}{2}\end{array}$ & $\frac{\Omega}{n}$ \\
\hline 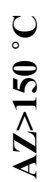 & 0 & 0 & 0 & 0 & 0 & 0 & 0 & 0 & 0 & $\overleftrightarrow{Z}$ \\
\hline
\end{tabular}




\begin{tabular}{|c|c|c|c|c|c|c|c|c|c|c|}
\hline $\begin{array}{l}0 \\
0 \\
\text { in } \\
\text { v } \\
\text { ê }\end{array}$ & 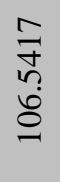 & $\begin{array}{l}\cong \\
\stackrel{+}{\Xi} \\
\exists\end{array}$ & $\begin{array}{l}\frac{\infty}{\Xi} \\
\stackrel{\Xi}{\Xi} \\
\Xi\end{array}$ & $\begin{array}{l}\tilde{n} \\
\tilde{n} \\
\text { ñ }\end{array}$ & 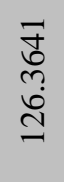 & 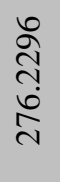 & $\frac{\infty}{n}$ & $\frac{\stackrel{?}{\sim}}{\stackrel{f}{\Xi}}$ & 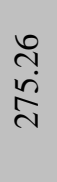 & 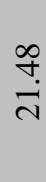 \\
\hline $\begin{array}{l}0 \\
0 \\
\\
\hat{0} \\
0\end{array}$ & 0 & 0 & 0 & 0 & 0 & 0 & 0 & 0 & 0 & 飞 \\
\hline 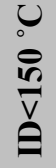 & 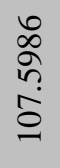 & 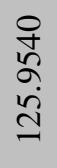 & 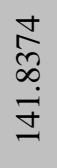 & $\begin{array}{l}\hat{\hat{a}} \\
\hat{b} \\
\dot{0}\end{array}$ & $\begin{array}{l}\text { నू } \\
\tilde{n} \\
\infty \\
\infty \\
m\end{array}$ & 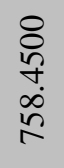 & 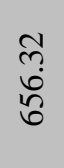 & 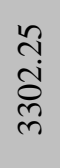 & 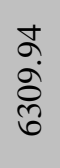 & ๙ొ? \\
\hline $\begin{array}{l}0 \\
0 \\
\hat{n} \\
\hat{n} \\
\hat{\theta}\end{array}$ & 0 & 0 & 0 & 0 & 0 & 0 & 0 & 0 & 0 & $\overleftrightarrow{\mathrm{z}}$ \\
\hline 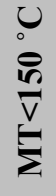 & 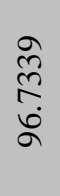 & $\begin{array}{l}\stackrel{n}{2} \\
\stackrel{2}{\infty} \\
\stackrel{0}{0}\end{array}$ & 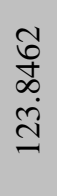 & $\begin{array}{l}\stackrel{\infty}{d} \\
\stackrel{0}{0} \\
\stackrel{+}{+}\end{array}$ & 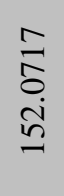 & 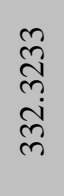 & $\stackrel{m}{\stackrel{n}{d}}$ & $\begin{array}{l}0 \\
\infty \\
\infty \\
\infty\end{array}$ & $\begin{array}{l}\bar{\sigma} \\
\ddot{\delta} \\
\text { ¿े }\end{array}$ & $\stackrel{\bar{n}}{\varrho}$ \\
\hline $\begin{array}{l}0 \\
0 \\
\hat{n} \\
\hat{\Lambda}\end{array}$ & 0 & 0 & 0 & 0 & 0 & 0 & 0 & 0 & 0 & $\overleftrightarrow{z}$ \\
\hline $\begin{array}{l}u \\
0 \\
\text { vo } \\
\bar{v} \\
\sum_{z}\end{array}$ & 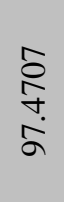 & 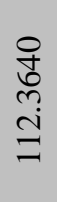 & $\begin{array}{l}m \\
\infty \\
8 \\
\text {. } \\
\stackrel{1}{-}\end{array}$ & $\begin{array}{l}\text { dै } \\
\text { तె } \\
\text { लn }\end{array}$ & $\begin{array}{l}\stackrel{\infty}{\circ} \\
\stackrel{\infty}{\infty}\end{array}$ & $\begin{array}{l}\stackrel{8}{0} \\
\text { Nं } \\
\text { ते }\end{array}$ & on & 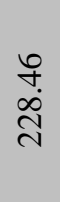 & $\begin{array}{l}\infty \\
\infty \\
\tilde{f}\end{array}$ & 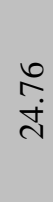 \\
\hline $\begin{array}{l}0 \\
0 \\
0 \\
\hat{n} \\
\hat{n}\end{array}$ & 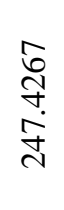 & $\begin{array}{l}\hat{\sigma} \\
\text { ָे } \\
\text { i } \\
\text { d }\end{array}$ & 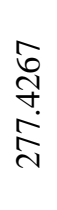 & $\begin{array}{l}\infty \\
\stackrel{\infty}{+} \\
\stackrel{n}{n} \\
\stackrel{n}{n}\end{array}$ & $\begin{array}{l}8 \\
\stackrel{2}{+} \\
\stackrel{8}{2}\end{array}$ & 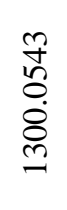 & $\begin{array}{l}\frac{n}{a} \\
\stackrel{a}{n}\end{array}$ & $\begin{array}{l}\stackrel{0}{\text { n}} \\
\stackrel{9}{+}\end{array}$ & $\begin{array}{l}\vec{b} \\
\dot{0} \\
\infty \\
\tilde{N}\end{array}$ & 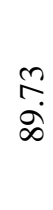 \\
\hline $\begin{array}{l}u \\
0 \\
o n \\
\text { D } \\
z \\
z\end{array}$ & $\begin{array}{l}\mathscr{\infty} \\
\infty \\
\stackrel{\infty}{\vdots} \\
\equiv\end{array}$ & 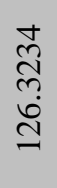 & 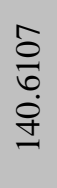 & $\begin{array}{l}\text { fo } \\
n \\
n \\
n\end{array}$ & 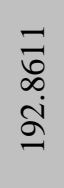 & 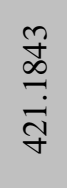 & $\begin{array}{l}\text { on } \\
n \\
n \\
n\end{array}$ & $\frac{\vec{f}}{\stackrel{\vec{n}}{\sigma}}$ & $\begin{array}{l}\text { in } \\
\text { i } \\
\infty \\
\\
\end{array}$ & $\begin{array}{l}\stackrel{\sigma}{\infty} \\
\infty\end{array}$ \\
\hline $\begin{array}{l}0 \\
0 \\
\stackrel{0}{n} \\
\hat{\lambda} \\
z\end{array}$ & $\begin{array}{l}\infty \\
\stackrel{0}{\circ} \\
\stackrel{\infty}{\circ} \\
\infty\end{array}$ & 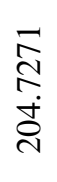 & $\begin{array}{l}\widehat{\delta} \\
\dot{J} \\
\stackrel{J}{J} \\
\text { त. }\end{array}$ & 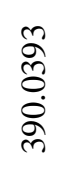 & $\begin{array}{l}\stackrel{O}{+} \\
\text { d̦ } \\
\stackrel{\text { t }}{\infty} \\
\infty\end{array}$ & $\begin{array}{l}\stackrel{\infty}{さ} \\
\stackrel{\Xi}{\Xi} \\
\underset{J}{J}\end{array}$ & 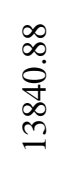 & $\begin{array}{l}\overrightarrow{+} \\
\text { ते } \\
\text { हె }\end{array}$ & 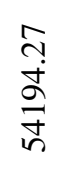 & 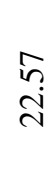 \\
\hline
\end{tabular}




\begin{tabular}{|c|c|c|c|c|c|c|c|c|c|c|}
\hline $\begin{array}{l}0 \\
0 \\
0 \\
\frac{n}{v} \\
\frac{0}{0}\end{array}$ & 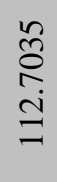 & 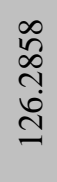 & $\begin{array}{l}\text { مू } \\
\hat{\sigma} \\
\dot{\delta} \\
\text { d }\end{array}$ & $\frac{\infty}{m}$ & $\frac{\stackrel{m}{+}}{\stackrel{m}{\grave{n}}}$ & $\begin{array}{l}\stackrel{0}{\sim} \\
\stackrel{\vec{n}}{\sigma} \\
\frac{\sigma}{0}\end{array}$ & $\begin{array}{l}\text { ô } \\
\text { ठ̊ } \\
\stackrel{0}{0}\end{array}$ & $\begin{array}{l}\tilde{\sigma} \\
\stackrel{\sim}{*} \\
\underset{d}{d}\end{array}$ & $\begin{array}{l}n \\
\infty \\
\infty \\
⿱ n \\
\forall\end{array}$ & $\begin{array}{l}\stackrel{\bullet}{0} \\
\dot{ \pm}\end{array}$ \\
\hline 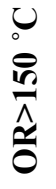 & $\begin{array}{l}\stackrel{尺}{2} \\
\stackrel{2}{0} \\
\infty \\
\infty\end{array}$ & \begin{tabular}{l}
$\vec{J}$ \\
\multirow{d}{N}{} \\
$\stackrel{N}{d}$
\end{tabular} & 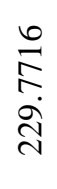 & 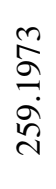 & $\begin{array}{l}\infty \\
\stackrel{\infty}{\infty} \\
\dot{m} \\
\infty\end{array}$ & 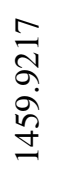 & $\begin{array}{l}\stackrel{\infty}{o} \\
\stackrel{+}{\beth}\end{array}$ & $\begin{array}{l}\stackrel{J}{\dot{d}} \\
\stackrel{\widehat{S}}{+}\end{array}$ & $\begin{array}{l}\text { กे } \\
\text { †े } \\
\text { bे }\end{array}$ & $\begin{array}{l}\curvearrowleft \\
\infty \\
\sim \\
n\end{array}$ \\
\hline 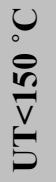 & 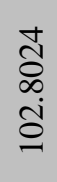 & $\begin{array}{l}\stackrel{ }{\sim} \\
\stackrel{\sim}{\sim} \\
ٍ\end{array}$ & 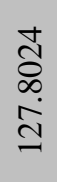 & $\begin{array}{l}\hat{\delta} \\
\delta \\
\dot{q}\end{array}$ & 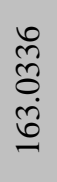 & $\frac{\frac{a}{n}}{\frac{n}{m}}$ & $\hat{0}$ & $\begin{array}{l}\stackrel{2}{\text {. }} \\
\text { 方 }\end{array}$ & $\begin{array}{l}\stackrel{a}{i} \\
\stackrel{\sim}{\sigma}\end{array}$ & $\frac{n}{n}$ \\
\hline 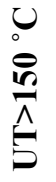 & $\begin{array}{l}\bar{n} \\
\tilde{n} \\
\tilde{N} \\
\text { n}\end{array}$ & 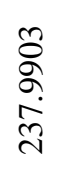 & 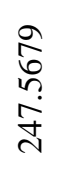 & 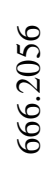 & $\begin{array}{l}\hat{\infty} \\
\infty \\
0 \\
\hat{\sigma} \\
\Xi \\
=\end{array}$ & 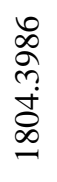 & $\begin{array}{l}\text { ஸे } \\
\stackrel{8}{0} \\
\text { }\end{array}$ & $\begin{array}{l}\stackrel{2}{\circ} \\
\dot{+} \\
\stackrel{2}{=}\end{array}$ & 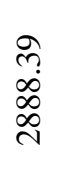 & $\begin{array}{l}+ \\
\text { ஸे }\end{array}$ \\
\hline $\begin{array}{l}0 \\
0 \\
\frac{0}{v} \\
\frac{v}{v} \\
3\end{array}$ & $\stackrel{O}{=}$ & $\stackrel{\cap}{=}$ & 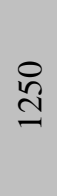 & $\begin{array}{l}\frac{n}{\circ} \\
\stackrel{0}{0} \\
\text { d }\end{array}$ & 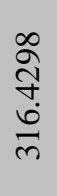 & 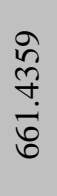 & $\begin{array}{l}\overline{0} \\
\stackrel{\oplus}{ }\end{array}$ & $\begin{array}{l}0 \\
\text { rn } \\
\text { ot }\end{array}$ & $\stackrel{n}{n}$ & $\begin{array}{l}\text { N̦ } \\
\infty\end{array}$ \\
\hline $\begin{array}{l}0 \\
0 \\
\frac{\pi}{n} \\
\frac{\pi}{2} \\
3\end{array}$ & 0 & 0 & 0 & 0 & 0 & 0 & 0 & 0 & 0 & $\overleftrightarrow{Z}$ \\
\hline $\begin{array}{l}0 \\
0 \\
0 \\
\bar{v} \\
\bar{v} \\
z\end{array}$ & ถู & $\stackrel{\text { I }}{ }$ & $\begin{array}{l}\stackrel{n}{n} \\
\end{array}$ & $\begin{array}{l}\infty \\
\infty \\
n \\
\\
\end{array}$ & 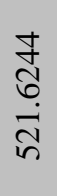 & 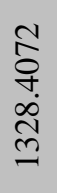 & $\begin{array}{l}\beth \\
\stackrel{\sim}{\simeq}\end{array}$ & 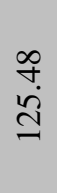 & 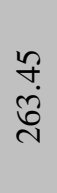 & $\begin{array}{l}\stackrel{0}{\sim} \\
\vec{\lambda}\end{array}$ \\
\hline \begin{tabular}{l}
0 \\
0 \\
0 \\
\multirow{n}{n}{} \\
$\hat{n}$
\end{tabular} & 0 & 0 & 0 & 0 & 0 & 0 & 0 & 0 & 0 & 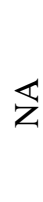 \\
\hline
\end{tabular}




\section{Appendix B: WV Geothermal Temperature Maps}

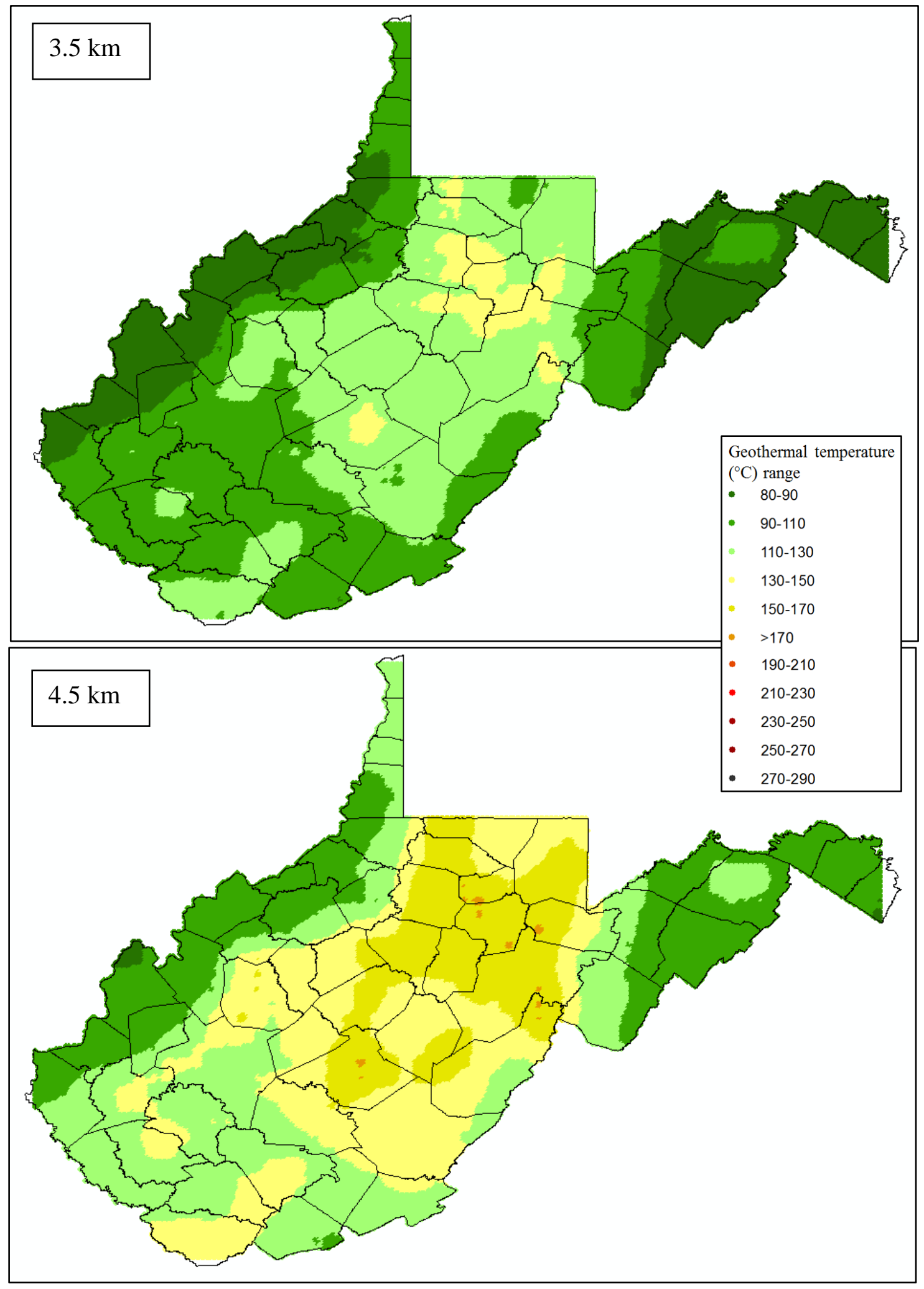




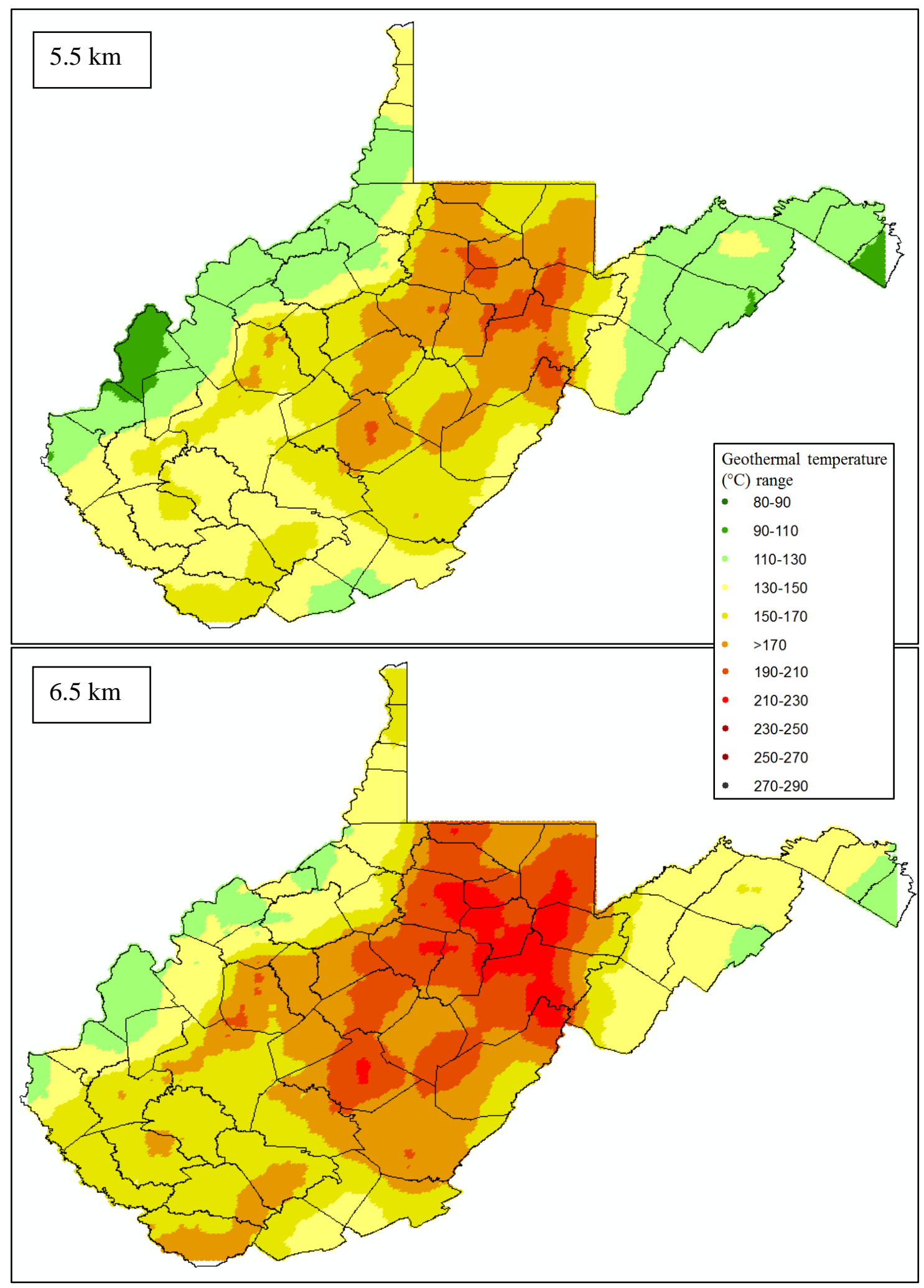




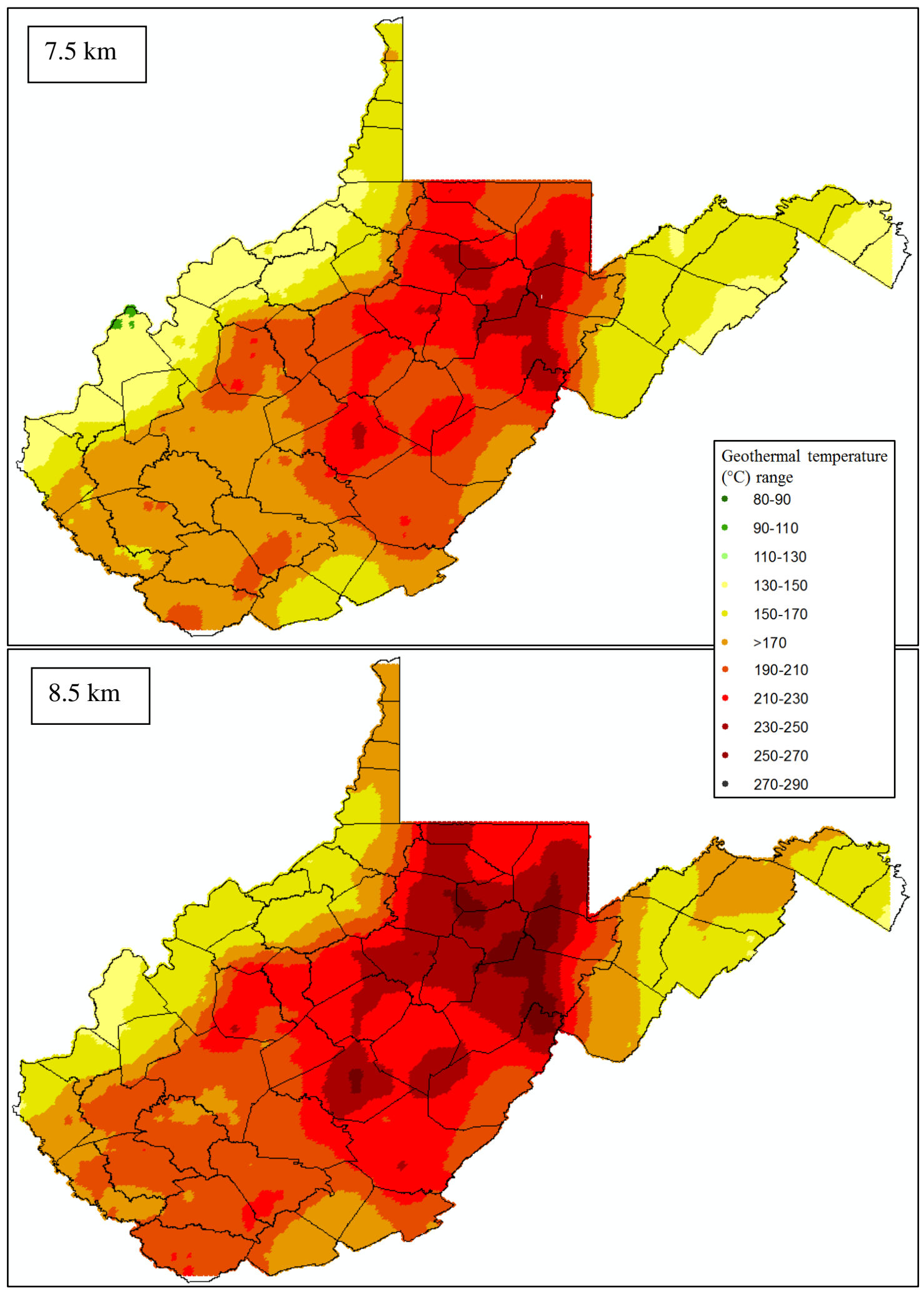




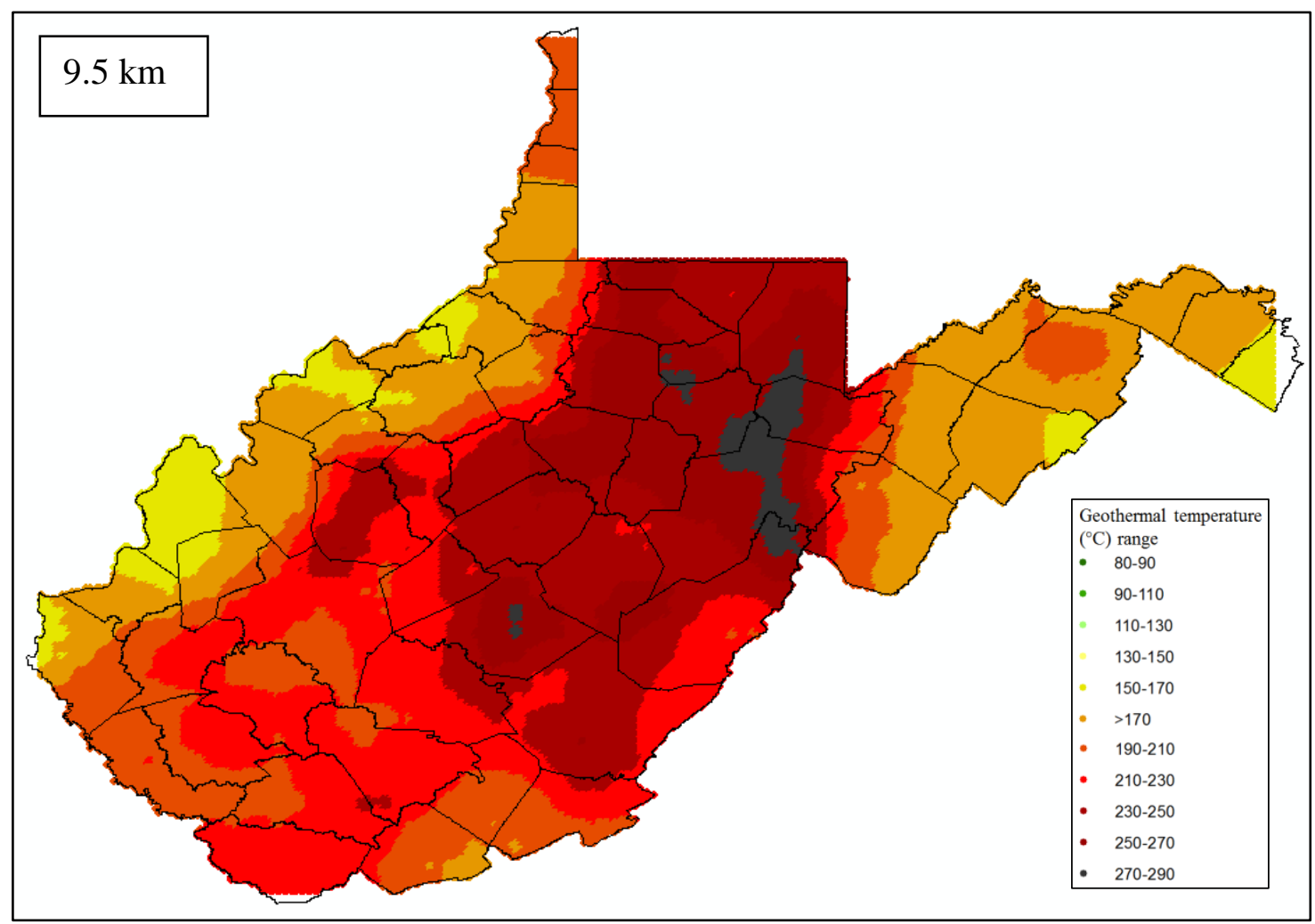

